\title{
Experimental Studies of the Early Effects of Inhaled Beta-Emitting Radionuclides for Nuclear Accident Risk Assessment
}

\author{
Phase II Report
}

Manuscript Completed: October 1987

Date Published: November 1987

Prepared by

B. R. Scott, F. F. Hahn, G. J. Newton, M. B. Snipes,

E. G. Damon, J. L. Mauderly, B. B. Boecker, D. H. Gray

S. S. Yaniv, NRC Project Manager

Inhalation Toxicology Research Institute

Lovelace Biomedical and Environmental Research Institute

P.O. Box 5890

Albuquerque, NM 87185

\section{Prepared for \\ Division of Regulatory Applications \\ Office of Nuclear Regulatory Research \\ U.S. Nuclear Regulatory Commission \\ Washington, DC 20555 \\ NRC FIN A1203}

\section{DISCLAIMER}

This report was prepared as an account of work sponsored by an agency of the United States Government. Neither the United States Government nor any agency thereof, nor any of their employees, makes any warranty, express or implied, or assumes any legal liability or responsibility for the accuracy, completeness, or usefulness of any information, apparatus, product, or process disclosed, or represents that its use would not infringe privately owned rights. Reference herein to any specific commercial product, process, or service by trade name, trademark, manufacturer, or otherwise does not necessarily constitute or imply its endorsement, recommendation, or favoring by the United States Government or any agency thereof. The views and opinions of authors expressed herein do not necessarily state or reflect those of the United States Government or any agency thereof. 


\section{DISCLAIMER}

This report was prepared as an account of work sponsored by an agency of the United States Government. Neither the United States Government nor any agency Thereof, nor any of their employees, makes any warranty, express or implied, or assumes any legal liability or responsibility for the accuracy, completeness, or usefulness of any information, apparatus, product, or process disclosed, or represents that its use would not infringe privately owned rights. Reference herein to any specific commercial product, process, or service by trade name, trademark, manufacturer, or otherwise does not necessarily constitute or imply its endorsement, recommendation, or favoring by the United States Government or any agency thereof. The views and opinions of authors expressed herein do not necessarily state or reflect those of the United States Government or any agency thereof. 


\section{DISCLAIMER}

Portions of this document may be illegible in electronic image products. Images are produced from the best available original document. 


\section{NOTICE}

This report was prepared as an account of work sponsored by an agency of the United States Government. Neither the United States Government nor any agency thereof, or any of their employees, makes any warranty, expressed or implied, or assumes any legal liability of responsibility for any third party's use, or the results of such use, of any information, apparatus, product or process disclosed in this report, or represents that its use by such. third party would not infringe privately owned rights.

\section{Availability of Reference Materials Cited in NAC Publications}

Most documents cited in NRC publications will be avaitable from one of the following sources:

1. The NRC Public Document Room, 1717 H Street, N.W. Washington, DC 20555

2. The NAC/GPO Sales Program. U.S. Nuclear Regulatory Commission, Washington, DC 20555

3. The National Technical Information Service, Springfield,..VA 22161

Although the listing that follows represents the majority of documents cited in NRC publications, it is not intended to be exhaustive.

Referenced documents available for inspection and copying for a fee from the NRC Public Docu. ment Room include NRC correspondence and ir,ternal NRC memoranda; NRC Office of Inspection and Enforcement bulletins, circulars, information notices, inspection and investigation notices; Licensee Event Reports; vendor reports and correspondence; Commission papers; and applicant and licensee documents and correspondence.

The following documents in the NUREG. series are available for purchase from the NRC/GPO Sales Program: formal NRC staff and contractor reports, NRC-sponsored conference proceedings, and NRC booklets and brochures. Also available are Regulatory Guides. NRC regulations in the Code of Federal Regulations, and Nuclear Regulatory Commission Issuances.

Documents available from the National Technical Information Service include NUREG series reports and technical reports prepared by other federal agencies and reports prepared by the Atomic Energy Cornmission, forerunner agency to the Nuclear Regulatory Commission.

Documents available from public and special technical libraries include all open literature items. such as books, journal and periodical articles, and transactions. Federal Register notices, federal and state legislation. and congressional reports can usually be obtained from these libraries.

Documents such as theses, dissertations, foreign reports and translations, and non-NRC conference proceedings are available for purchase trom the organization sponsoring the publication cited.

Single copies of NRC draft reports are available free upon written request to the Division of Technical Information and Document Control, U.S. Nuclear Regulatory Commission. Washington, DC 20555.

Copies of industry codes and standards used in a substantive manner in the NRC regulatory process are maintained at the NRC Library. 7920 Norfolk Avenue. Bethesda. Maryland, and are available there for reference use by, the public. Codes and standards are usually copyrighted and may be purchased from the originating organization or. if they are American National Standards. from the American National Standards Institute. 1430 Broadway. New York, NY 10018. 
PREVIOUS DOCUMENTS IN SERIES

F. F. Hahn, Inhalation Toxicology Research Institute, "Early Mortality Estimates for Different Nuclear Accidents," USNRC Report NUREG/CR-0774, August 1979. Available for purchase from National Technical Information Service, Springfield, VA 22161. 
This report summarizes a series of experiments concerning the effect of linear energy transfer and temporal radiation dose pattern to the lung from inhaled beta-emitting radionuclides. The results were used to test the validity of a hazard-function mathematical model for predicting death from radiation pneumonitis. Both morbidity and mortality within 18 months after exposure were examined in rats exposed to beta-emitting radionuclides, giving brief or protracted irradiation of the lung or having weak or strong beta emissions. Protraction of the radiation dose to the lung from a half-time in the lung of less than three days to a half-time with a long-term component of about 150 days has a sparing effect. The median lethal dose for the protracted irradiation is about 1.7 times the median lethal dose for the brief irradiation. Low energy beta emissions (from $147 \mathrm{Pm}$ ) have a similar effectiveness in producing lethal injury as high energy beta emissions (from $90 \mathrm{Sr}$ ). Changes in three parameters of morbidity were measured: body weight, hematology and pulmonary function; only changes in pulmonary function correlated well with pulmonary radiation injury. The doses of radiation required to produce impaired function. however, were not significantly different from those that produced death.

The hazard-function model for predicting death from radiation pneumonitis, which was developed from previously obtained data for inhalation exposures of dogs to beta-emitting radionuclides, adequately predicted the median lethal doses for rats receiving one of several different beta dose rate patterns to the lung, thus strengthening the validity of the mathematical model. Future research is expected to lead to development of more general models. The data provided in this report can be used to develop and validate such models. 


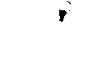
. 
PAGE

I. EXeCUtive SUMMARY . . . . . . . . . . . . . . . . . . . . . . . . . . . . . . 1

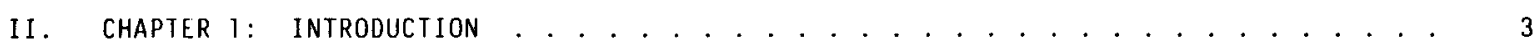

III. CHAPTER 2: EARLY EFFECTS OF LOW-ENERGY BETA IRRADIATION OF THE LUNG. . . . . . . . . 5

2.1 Introduction . . . . . . . . . . . . . . . . . . . . . . . . . 5

2.2 Methods. . . . . . . . . . . . . . . . . . . . . . . . . . 5

2.3 Results . . . . . . . . . . . . . . . . . . . . . . . . . . 8

2.3.1 Radiation Doses to Lung. . . . . . . . . . . . . . . . . . . . . . . 8

2.3.2 Survival Distribution..................... . . . . . 9

2.3 .3 Body Weight Data..................... 12

2.3.4 Hematological Data...................... . . 15

2.3.5 Mortality Data..................... . . 15

2.4 Discussion. . . . . . . . . . . . . . . . . . . . . . . . . 17

2.5 Summary. . . . . . . . . . . . . . . . . . . . . . . . 17

IV. CHAPTER 3: THE INFLUENCE OF RADIATION DOSE RATE PATIERN ON EARLY EFFECTS

IN THE LUNG. . . . . . . . . . . . . . . . . . . . . . . . . 19

3.1 Introduction .......................... . . . . 19

3.2 Methods . . . . . . . . . . . . . . . . . . . . . . . 19

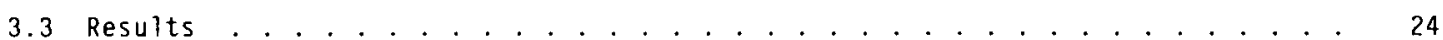

3.3.1 Radiation Doses to Lung. . . . . . . . . . . . . . . . . . . . 24

3.3.2 Survival Distribution. . . . . . . . . . . . . . . . . . . 28

3.3.3 Body Weight Data......................... . 31

3.3.4 Hematological Data....................... . 31

3.3 .5 Pulmonary function Data. . . . . . . . . . . . . . 31

3.3 .6 Mortality Data....................... 39

3.4 Discussion. . . . . . . . . . . . . . . . . . . . . . . . . . . . . . . . 39

V. CHAPTER 4: IMPLICATIONS FOR REACTOR ACCIDENT CONSEQUENCE MODELING. . . . . . . . . . . . 43

4.1 Introduction. . . . . . . . . . . . . . . . . . . . . . . . . 43

4.2 Hazard Function Model Testing and Refinements . . . . . . . . . . . . . . . 43

4.3 Morbidity Data Implications. . . . . . . . . . . . . . . . . . . . . . . 49

VI. REFERENCES. . . . . . . . . . . . . . . . . . . . . . . . . . 51

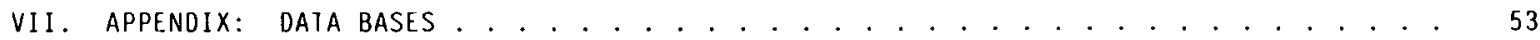


2.1 Pulmonary retention pattern for inhaled $147 \mathrm{Pm}$ in fused aluminosilicate particles.

2.2 Calculated pulmonary dose accumulation pattern after inhalation of $147 \mathrm{Pm}$ in fused aluminosilicate particles.

2.3 Time to death from radiation pneumonitis and its relation to initial lung burden after inhalation of $147 \mathrm{Pm}$ in fused aluminosilicate particles. Triangles represent time to death or euthanasia due to radiation pneumonitis. The horizontal bar represents survivors at the end of the study. Open circles represent lung tumors and closed circles represent other effects.

2.4 Distribution of survival times for rats dying of radiation pneumonitis and pulmonary fibrosis after inhalation of $147 \mathrm{Pm}$ in fused aluminosilicate particles. Vertical ticks bracket the time intervals.

2.5 Percent body weight gain at 10 weeks after exposure vs initial weight for maie control rats.

2.6 Percent body weight gain at 10 weeks after exposure vs initial weight for female control rats.

2.7 Body weight gain at 10 weeks after exposure vs initial weight for male control rats.

2.8 Body weight gain at 10 weeks after exposure vs initial weight for female control rats.

2.9 Body weight gain for male rats after inhalation exposure to $147 \mathrm{Pm}$ in fused aluminosilicate particles. Four groups are: controls, low, medium, and high that have doses in units of $D_{50}$ of $0,0.003-0.44,0.44-1.2$ and $1.2-1.8$, respectively.

2.10 Body weight gain for female rats after inhalation exposure to $147 \mathrm{Pm}$ in fused aluminosilicate particles. Four groups are: controls, medium, and high that have doses in units of $0_{50}$ of $0,0.017-0.70,0.83-1.7$ and $1.8-3.8$, respectively.

2.11 Lymphocyte concentration after inhalation exposure (males and females combined): 10w = D50 units of $0.003-0.22$, moderate $=0_{50}$ units of $0.26-1.1$, high $=050$ units of $1.3-2.3$.

2.12 Dose-response curve for death from radiation pneumonitis after inhalation of $147 \mathrm{Pm}$ in fused aluminosilicate particles by rats.

3.1 Pulmonary retention pattern for inhaled $90_{\mathrm{Sr}}$ in fused aluminosilicate particles. $0_{50}=1770$ $\mathrm{kBq} / \mathrm{g}$ lung or a 900 day dose of 370 Gy $(37,000 \mathrm{rad})$.

3.2 Calculated pulmonary dose accumulation pattern after inhalation of $90 \mathrm{Sr}$ in fused aluminosilicate particies.

3.3 Pulmonary retention pattern for inhaled $90 y$ mixed with $2.3 \% 90$ Sr in fused aluminosilicate particles.

3.4 Calculated pulmonary dose accumulation pattern after inhalation of $90 \mathrm{Y}$ mixed with $2.3 \% 90 \mathrm{Sr}$ in fused aluminosilicate particles.

3.5 Pulmonary retention pattern for inhaled $90 \mathrm{Y}$ mixed with $25 \% 90 \mathrm{Sr}$ in fused aluminosilicate particles.

3.6 Calculated pulmonary dose accumulation pattern after inhalation of $90 \mathrm{Y}$ mixed with $25 \% 90 \mathrm{Sr}$ in fused aluminosilicate particles.

3.7 Time to death from radiation pneumonitis and its relation to initial lung burden after inhalation of $90 \mathrm{Sr}$ in fused aluminosilicate particles. A dose of 1 in units of the $D_{50}$ equals a $50 \%$ lethality dose for death from radiation pneumonitis and corresponds to 1200 $\mathrm{kBq} / \mathrm{g}$ lung or a 900 day dose of 370 Gy $(37,000$ rad). Includes animals in mortality. hematology and pulmoriary function groups. 
3.8 Time to death from radiation pneumonitis and its relation to dose after inhalation of $90 \mathrm{Y}$ mixed with 2.3\% $90 \mathrm{Sr}$ in fused aluminosilicate particles. A dose of 1 in units of the $D_{50}$ equals a 50\% lethality dose for death from radiation pneumonitis and corresponds to 10,000 $\mathrm{kBq} / \mathrm{g}$ lung or a 900 day dose of 200 Gy $(20,000$ rad). Includes animals in mortality, hematology and pulmonary function groups.

3.9 Time to death from radiation pneumonitis and its relation to dose after inhalation of $90 \mathrm{Y}$ mixed with $25 \% 90 \mathrm{Sr}$ in fused aluminosilicate prticles. A dose of 1 in units of the $0_{50}$ equals a 50\% lethality dose for death from radiation pneumonitis and corresponds to 4000 $\mathrm{kBq} / \mathrm{g}$ lung or a 900 day dose of 330 Gy $(33,000$ rad). Includes animals in mortality, hematology and pulmonary function groups.

3.10 0istribution of survival of times for rats dying of radiation pneumonitis and pulmonary fibrosis after inhalation of either $90 \mathrm{Sr}, 90_{Y}+2.3 \% 90_{S r}$ or $90_{Y}+25 \% 90 \mathrm{Sr}$ in fused aluminosilicate particles.

3.11 Body weight gain for male rats after inhalation exposure to $90_{S r}$ in fused aluminosilicate particles. Four dose groups are shown: controls, low, medium and high with average doses in units of the $D_{50}$ of $0,0.0,0.1,0.6$ and 1.4 , respectively.

3.12 Body weight gain for female rats after inhalation exposure to $90 \mathrm{Sr}$ in fused aluminosilicate particles. Four dose groups are shown: controls, low, medium and high with average dases in units of the $D_{50}$ of $0,0.0,0.2,0.4$ and 1.2 , respectively.

3.13 Body weight gain for male rats after inhalation exposure to $90 \mathrm{Y}+2.3 \% 90 \mathrm{Sr}$ in fused alumincsilicate particles. Low, medium and high groups have average doses in units of the $0_{50}$ of $0.7,1.3$ and 2.0 , respective $7 y$.

3.14 Body weight gain for female rats after inhalation exposure to $90 \mathrm{Y}$ and $2.3 \% 90 \mathrm{Sr}$ is fused aluminosilicate particles. Low, medium and high groups have average doses in units of the 050 of $0.5,0.8$ an 1.4 , respectively.

3.15 Body weight gain for male rats after inhalation exposure to $90 \mathrm{Y}+25 \% 90 \mathrm{Sr}$ in fused aluminosilicate particles. Low, medium and high groups have average doses in units of the $D_{50}$ of $0.1,0.3$ and 0.9 , respectively.

3.16 Body weight gain for female rats after inhalation exposure to $90 Y+25 \% 90$ Sr in fused aluminosilicate particies. Low, medium and high groups have average doses in units of the $D_{50}$ of $0.1,0.3$ and 1.1 , respectively.

3.17 Blood lymphocyte concentration after inhalation exposure to $90 \mathrm{~s} r$ in fused aluminosilicate particles. Low, medium and high groups have average doses in units of the 050 of $0.04-0.2$, $0.2-1.0$ and $1.7-2.4$, respectively.

3.18 Blood Tymphocyte concentration after inhalation exposure to $90 \mathrm{y}+2.3 \% 90 \mathrm{sr}$ in fused aluminosilicate particles. Low, medium and high groups have average doses in units of $D_{50}$ of $0.2-0.8,0.8-1.2$ and $1.2-2.2$, respectively.

3.19 Blood lymphocyte concentration after inhalation exposure to $90 \mathrm{Y}+25 \% 90 \mathrm{Sr}$ in fused aluminosilicate particles. Low and medium groups have average doses in units of $0_{50}$ of 0.04-0.2 and 0.2-0.3, respectiveiy.

3.20 Relationship of vital capacity to age (months after exposure from age 15 weeks) for control male rats. Linear regression 1 ine with $95 \%$ confidence region.

3.21 Relationship of co diffusing capacity to age (months after exposure from age 15 weeks) for control male rats. Linear regression line with $95 \%$ confidence region.

3.22 Relationship of quasistatic lung compliance to age (months after exposure from age 15 weeks) for control mae rats. Linear regression 1 ine with $95 \%$ confidence region.

3.23 Co diffusing capacity per alveolar volume as function of age (months after exposure from age 15 weeks). Linear regression line with $95 \%$ confidence region. 
3.24 Vital capacity to total lung capacity ratio as function of age (months after exposure from age 15 weeks). Linear regression line with $95 \%$ confidence region.

3.25 co diffusing capacity per alveolar volume vs cumulative radiation dose to the 1 ing from 90 sr for various followup times. Rats of both sexes that died within T.5 years after exposure are included.

3.26 co diffusing: capacity per alveolar volume vs cumulative radiation dose to the lung from 90 sr for rats of both sexes that survived to and were tested at 1.5 years after exposure.

3.27 Dose-effect relationship for co diffusing capacity per alveolar volume normalized to percent of control values based on measurements obtained from rats of both sexes. Cumulative Gy to the lung from $90 y$ at the time measurements were taken are used as dose.

3.28 Dose response curves for death from radiation preumonitis after inhalation of $90 \%+2.3 \%$ Sr. $90 Y+25 \% \mathrm{Sr}$ or $90 \mathrm{Sr}$ in fused aluminosilicate particles by rats.

4.1 Dose accumulation pattern after inhalation of $147 \mathrm{Pm}, 905 r, 90 Y+2.3 \% 905 r, 0 r 90 y+25 \%$ 90 Sr inhaled in fused aluminosilicate particies. 
2.1 Experimental design for rats exposed to $147 \mathrm{Pm}$ inhaled in fused aluminosilicate particles.

2.2 Number of lung tumors to 1.5 years after exposure in rats exposed by inhalation to $147 \mathrm{pm}$ in fused aluminosilicate particles.

3.1 Experimental design for rats exposed by inhalation to $90 \mathrm{sr}$ in fused aluminosilicate particles.

3.2 Experimental design for rats exposed by inhalation to $90 y$ in fused aluminosilicate particles.

3.3 Experimental design for rats exposed by inhalation to $90 \mathrm{Sr}+90 \mathrm{y}$ in fused aluminosilicate particles.

3.4 Response probability estimates for 20,30 or 50 rats per group.

3.5 Comparison of survival times in rats exposed to beta-emitting radionuclides with differing half-times in the lung.

3.6 Comparison of effect of inhaled beta emitters on body weight gain.

3.7 Summary of various expressions of median lethal doses ( $\left.0_{50}\right)$ and shaper parameters (V) for death from radiation pneumonitis and pulmonary fibrosis.

4.1 Expected and observed median lethal doses for death from radiation pneumonitis.

4.2 Expected and observed median lethal doses for death from radiation pneumonitis based on bias adjusted formula.

4.3 Comparison of median lethal dose to cause death from radiation pneumonitis. 
ACKNOWLEDGEMENTS

Research was supported by the Nuclear Regulatory Commission under an interagency agreement with the Department of Energy office of Health and Environmental Research under Contract Number OE-ACO4-76EV01013 and carried out in animal care facilities fully accredited by the American Association for Laboratory Animal Care. Many of the staff at the Inhalation Toxicology Research Institute contributed to this research. Dr. Shlomo Yaniv served as the NRC Project officer and was instrumental in many of the design aspects of these studies. 
A major concern of the Nuclear Regulatory Commission (NRC) and general public is the potential for health effects from nuciear accidents. In Phase I of this project, a mathematical model was developed at the Inhalation Toxicology Research institute (ITRI) for the NRC for predicting the fatalities from early and continuing effects of exposure of persons to radiation that might occur following an accident at a light water nuclear power plant (Hahn 1979). The model initially developed for overall lethality contained three organ-specific modes for lethality: (1) injury to the bone marrow, (2) injury to the colon and (3) injury to the lungs. Subsequent analysis efforts led to refinement of the overall lethality model which included the addition of a mode for lethality from injury to the small intestine.

In Phase II of the project, three specific inhalation exposure studies were carried out at the ITRI. The purposes of the studies were two-fold: (1) to validate and improve the lethality model for death from early and continuing effects in lung after exposure to different dose rate patterns from beta-emitting radionuclides, and (2) to provide data for developing a morbidity model when lung is the target organ.

This document provides a detailed description of two of the three studies on early and continuing effects in lung, resulting from inhalation of radionuclides. In the first study, the influence of cross-organ irradiation was examined by exposing rats to aerosols of $147 \mathrm{Pm}$ that irradiated only the lung because of the weak-energy betas emitted. In a second study, the influence of different dose accumulation patterns on morbidity and mortality were examined. Results of another study in which rats were exposed via inhalation to mixtures of alpha emitters and beta emitters ( $147 \mathrm{Pm}$ and $238 \mathrm{Pu}$ incorporated into insoluble particles), will be presented in a subsequent report.

Each radionuclide was delivered within an insoluble fused aluminosilicate particle (FAP) matrix and resulted in a different dose rate pattern of irradiation of the lung. Initial dose rates were highest for $90 \mathrm{Y}$, followed by the mixture $90 \mathrm{Y}+90 \mathrm{Sr},{ }^{90} \mathrm{Sr}, \mathrm{a}$ and $147 \mathrm{Pm}$, respectively. Initial dose rates and lung clearance patterns were similar for $147 \mathrm{Pm}$ and $90 \mathrm{Sr}$ but the energies of the beta emissions from $147 \mathrm{Pm}$ were much lower than for those from ${ }^{90} \mathrm{Sr}$ and thus the range in tissue was much less. Therefore, the dose from $147 \mathrm{Pm}$ was delivered mostly to the lung, while a major fraction of the dose from $90 \mathrm{Sr}$ or $90 \mathrm{Y}$ was delivered to tissues adjacent to the lung.

The rats were observed for signs of illness and for survival out to 1.5 years after exposure. Periodic measurements obtained as potential indicators of illness were hematocrit, red and white blood cell counts, and differential white blood cell counts, as well as several pulmonary function parameters including vital capacity, carbon monoxide diffusing capacity, and quasistatic compliance of the lung. Body weights of all rats were measured periodically throughout each study. Pulmonary function evaluations were carried out on a preselected group of rats throughout the ${ }^{90} \mathrm{Sr}$ experiment and at the end of both the $90 \mathrm{Sr}$ and $90 \mathrm{Y}$ experiments. Hematological evaluations were also carried out on preselected rats throughout each experiment.

Major findings of these studies of irradiation of lungs of rats by internally deposited beta emitters were as follows:

1. Low-energy beta emissions from ${ }^{147} \mathrm{Pm}$ have similar effectiveness in producing lethal injury as high-energy beta emissions from $90 \mathrm{Sr}$ indicating that the high-energy beta particles escaping the lung of rats and irradiating surrounding tissues do not significantly alter lethality.

\footnotetext{
as used in this text, the term ${ }^{90} \mathrm{Sr}$ refers to an equilibrium mixture of $90_{\mathrm{Sr}}$ and $90 \mathrm{Y}$. The term $90 Y+90 S r$ refers to an equilibrium mixture of $90_{S r}+90_{Y}$ to which additional $90 Y$ had been added.
} 
2. Unlike high-energy beta emitters, low-energy beta emissions from $147_{P m}$ were not effective in producing injury to the hematopoietic system. While a slight temporary reduction in lymphocytes was observed after exposure to the high-energy beta emitters, none was observed after exposure to the low-energy beta emissions of $147 \mathrm{Pm}$.

3. Protraction of the radiation dose to the lung from a half-time in the lung of less than 3 days to a half-time with a long-term component of about 150 days has a sparing effect. 1he median lethal dose for the protracted irradiation is about 1.7 times the medial lethal dose for the brief irradiation.

4. Doses of beta irradiation required to produce impaired pulmonary function were similar to those required for lethality.

5. Individuals with impaired pulmonary function shortly after inhalation exposure to beta emitters have, or are likely to accumulate, lethal pulmonary injury.

6. Body weight in rats is not a sensitive measure of illness associated with radiation damage to the lung. However, a significant decrease in body weight correlated with the induction of lethal pulmonary injury.

7. The hazard-function model for predicting death from radiation pneumonitis, which was developed from data for inhalation exposure of dogs to beta-emitting radionuclides, adequately predicted the median lethal doses for rats receiving one of several different beta dose rate patterns to the lung. 
CHAPTER 1

INTRODUCTION

The main focus of the research reported here is on early and continuing effects of irradiation of the lungs and its relevance to nuclear reactor accident risk assessment. Two modes of exposure could occur in an accident at a light water nuclear power plant: (1) brief external exposure to ground-shine and cloud-shine gamma rays at high dose rates, and (2) protracted internal exposure due to inhaled and ingested radionuclides.

Large doses to the lungs from inhaled radionuclides can cause radiation pneumonitis and pulmonary fibrosis and may lead to impaired pulmonary function and death. The severity of reactions and their time course depend on total radiation dose (Collis and Steel, 1982; Phillips and Margolis, 1972), dose rate (Travis et al., 1983; Depledge and Barrett, 1982), and type of radiation (Mauderly et al., 1980). Although the histologic descriptions of radiation pneumonitis are based primarily on observations of man or laboratory animals exposed to external thoracic $x$-irradiation, similar changes have been observed with inhaled radionuclides (Slauson et al., 1976; Slauson et al., 1977). One major difference is the time course of the lesions, which is more delayed depending on the degree of dose protraction associated with the particular radionuclide.

In a recent evaluation of data for exposure of human lung to external x-irradiation, the onset of pneumonitis was shown to be between 1 and 7 months after irradiation, with no correlation between time of onset and radiation dose to the lung over a range of 6.5 to 12.5 Gy (650-1250 rad) (Van Dyk et aI., 1981).

Morbidity after inhalation exposure of the lung to nonlethal beta-radiation doses has been demonstrated using pulmonary function measurements in Beagle dogs that inhaled $90 y$ in an insoluble form (Mauderly et al.. 1973). Functional measurements were performed under the stresses of treadmill exercise and added external deadspace. The smallest dose to the lung that was observed to cause alteration in lung function was approximately one-half of the estimated median lethal dose $\left(0_{50}\right)$. Results of the studies by Mauderly and coworkers have been interpreted as indicating that the low-LET dose required to cause morbidity may be about one-half that required for lethality (Scott and Hahn, 1985).

Previously available information suggests that age at exposure can influence the effectiveness of the radiation (Mcclellan et al.. 1982). About one-half as much dose to the lungs was required for immature and aged dogs as was required for young adults to cause death from early effects. This has been interpreted as indicating that children and the aged may be more sensitive than young adults, by about a factor of two, to lethality from exposure of the lungs (Scott and Hahn, 1985).

The main objective of this document is to describe mortality and morbidity for rats that were exposed via inhalation to large doses of beta radiation to the lung. The research that produced these data represents phase II of a two-phased project. In Phase I, a computer simulation model was developed for assessing the risk of death from early and continuing effects that could arise from radiation exposure associated with an accident at a light water nuclear power plant.

In Phase II, experiments were conducted to (1) provide data on mortality to validate the mortality model developed in Phase $I$ and (2) provide data on morbidity for developing a morbidity mode1. The data are derived from studies in which rats were exposed via inhalation to $147 \mathrm{pm}$, $90 \mathrm{Sr}$ (in equilibrium with 90Y), $90 \mathrm{Sr}$ (in equilibrium with 90Y) plus additional 90Y, or 90Y only. Each radionuclide was delivered in a relatively insoluble fused aluminosilicate particle (FAP) matrix. 
Throughout the document, ${ }^{90} \mathrm{Sr}$ will refer to an equilibrium mixture of ${ }^{90} \mathrm{Sr}$ and its daughter radionuclide $90 \mathrm{Y}$. A data base is also being developed from rats exposed via inhalation to $147 \mathrm{Pm}$ plus $238 \mathrm{pu}$ inhaled in fused aluminosilicate particles, but these data will be described in a subsequent report. 
CHAPTER 2

EARLY AND CONTINUING EFFECIS OF LOW-ENERGY BETA IRRADIATION OF THE LUNG

\subsection{INTRODUCTION}

The purpose of the study was to determine if irradiation of organs other than lung by high-energy beta particles, such as from ${ }^{90} \mathrm{Sr}$ deposited in the lung, leads to greater mortality than would be expected if only the lung was irradiated. Of special interest was the potential for cross-organ irradiation and injury to the hematopoietic system by high-energy beta rays originating in the lung and escaping to irradiate the bone marrow of the sternum, ribs and thoracic vertebra as well as the blood passing through the lung. If injury to the hematopoietic system was significant, then it would be reflected in depressed peripheral leucocyte counts measured at various times after exposure. The hypothesis tested in this study was that low-energy beta irradiation from $147 \mathrm{Pm}$ (Emax $=0.224 \mathrm{MeV}$ ), localized in the lung, would not produce detectable injury to the hematopoietic system through irradiation of the bone marrow. However, some of the high energy beta emissions from $90 \mathrm{Sr}$ or $90 \mathrm{Y}$ (Emax of $90 \mathrm{Y}=2.27$ MeV) wauld escape the lung and could cause detectable injury to the hematopoietic system via irradiation of the bone marrow. The experiments invoiving high energy beta emitters are discussed in chapter 3.

It will be demonstrated that, while $147 \mathrm{Pm}$ caused deaths from radiation pneumonitis and pulmonary fibrosis and a reduction in weight gain, no observable injury occurred to the hematopoietic system when this low-energy beta emitter was localized in the lung of rats. In addition, deaths from radiation pneumonitis and pulmonary fibrosis were observed even at the last sacrifice time, 1.5 years after inhalation exposure, a time when tumors of the lung were also observed.

\subsection{METHOOS}

\subsection{Animals}

Equal numbers of male and female $\mathrm{F} 344 / \mathrm{Cr}$ rats were obtained from the Lovelace ITRI breeding colony for use in the study. The breeding colony is free of known rat respiratory pathogens and is tested serologically every three months. The rats were $15 \pm 2$ weeks of age at exposure.

\subsubsection{Animal Maintenance}

Before exposure, members of each sex were weighed and housed separately, 2 per cage, in polycarbonate cages with aspen bedding and filter caps. The room housing the rats was maintained between 20 to $22^{\circ} \mathrm{C}$ and the relative humidity was maintained between 20 to $50 \%$. A 12 -hour-on. 12-hour-off light cycle was used. Rats were given food (Lab Blox, Allied Mills, Chicago, IL) and water ad libitum.

\subsubsection{Biologic Measurements}

Biological measurements made during the study were body weight, hematology, survival time and histologic changes at death. Body weights were taken before exposure and at monthly intervals to 6 months and again at 12 months after exposure on all rats.

Hematological examinations were performed on rats in the hematology group before exposure and at $7,14,30,60,90,180$ and 540 days after exposure. Blood was collected from the retrobulbar sinus in a capillary tube. Smears were made and the blood was diluted in Unopettes ${ }^{\circ}$ Hematocrit, total red blood cells, total white blood cells and white blood cell differential counts were determined. Total blood cell counts were performed with an electronic blood cell counter (coulter 5550 ).

The rats were observed twice per day for 1.5 years after exposure. Those moribund were euthanized and necropsied. At the end of the observation period, a representative number of rats was sacrificed, necropsied and examined for histologic changes. At necropsy, all animals were 
examined for gross lesions and the likely cause of death was determined. All major organ systems were examined except for the brain. The lungs were weighed and perfused with $10 \%$ neutral buffered formalin embedded in paraffin, sectioned at 5 micrometers and stained with hematoxylin and eosin for histologic evaluation.

\subsubsection{Aerosol Preparation And Generation}

Polydisperse aerosols were prepared by cation exchange of $147 \mathrm{Pm}$ and $169 \mathrm{Yb}$ into montmorillonite clay, followed by aerosolization with a Lovelace nebulizer and heat treatment by passing through a heating column at $1150^{\circ} \mathrm{C}$ with a flow rate of $2 \mathrm{Lpm}$. The aerosol, was then diluted with clean air and directed into an 80-port, nose-only exposure chamber. Cascade impactor, filter, and electrostatic precipitator (ESP) samples of the aerosol were takent the beginning and near the end of each exposure; these samples were used to determine physical characteristics of the aerosols and aerosol radioactivity during inhalation exposure.

The particle size distributions were lognormal. The range for activity median aerodynamic diameters among the different inhalation exposure runs was 0.9 to 1.77 micrometers. The range of the geometric standard deviation was 1.5 to 1.8 .

2.2.5 Determination of Lung and Bronchial Lymph Node Radioactivity Content

Because $147 \mathrm{Pm}$ in fused aluminosilicate particles is relatively insoluble in body fluids, the lungs and bronchial lymph nodes $(B L N)$ of the rats were the organs of primary interest. At death or sacrifice, whole-body, lung and BLN weights were measured. Fixed lung and lymph node tissue remaining after sampling for histopathology were reweighed, wet-ashed, sampled and counted in triplicate using 7 iquid scintillation techniques to determine the $147 \mathrm{Pm}$ content. Corrections were made for quench using external standards and for loss of tissue samples taken for histopathology. Results were used to obtain the content of $147 \mathrm{Pm}$ in lungs and lymph nodes at death.

\subsubsection{Estimation of Initial Lung Burdens}

Initial lung burdens (ILB) of $147 \mathrm{Pm}$ were estimated indirectly by measuring whole-body $169 \mathrm{Yb}$ activity at early times ( 4 to 8 days after exposure). Shielded NaI(II) crystal counters were used to detect gamma radiation from the $169 \mathrm{yb}$ radioactive tag. The observed whole-body radioactivity in the animal at 4-8 days after exposure was assumed to represent the existing lung burden. An exponential retention relationship was derived for retention of $169 \mathrm{yb}$. After it was corrected for physical decay of $169 \mathrm{Yb}$, a biological (total-body) clearance fraction of approximately 0.032 per day was observed. Knowing the $147 \mathrm{Pm}_{\mathrm{m}}$ to $167 \mathrm{Yb}$ initial activity ratio (approximately 80 to 1 calculated from the filter samples collected at exposure) and the physical half-life of $147 \mathrm{Pm}$ (2.62 years), the initial $147 \mathrm{pm}$ lung burden was estimated by extrapolating back to the time of exposure. The initial lung burden estimates obtained for each rat are given in the Appendix.

\subsubsection{Estimation of Doses To Lung}

Lung burden estimates derived at early times from whole-body counting of : $169 \mathrm{yb}$ were coupled with those obtained for animals that died throughout the study whose. lungs were analyzed radiochemically for $147 \mathrm{Pm}$ content to obtain an effective lung retention function given by ...

$$
{ }^{147} \mathrm{Pm} \text { lung retention }=0.58 \exp (-0.15 \mathrm{~T})+0.42 \exp (-0.0046 \mathrm{~T})
$$

where $T$ represents days after inhalation exposure. The retention, function: is plotted in Figure 2.1. The effective retention half-time for the long-term component was 150 days.

Cumulative radiation doses to the lung to death or doses to a specified time (e.g., 1 year after inhalation exposure) were determined by numerical integration over the dose rate pattern for each exposed individual. Instantaneous dose rates, $D R(t)$, at any given $t$ ime $t$ in the interval from 0 to 550 days after exposure were given by 


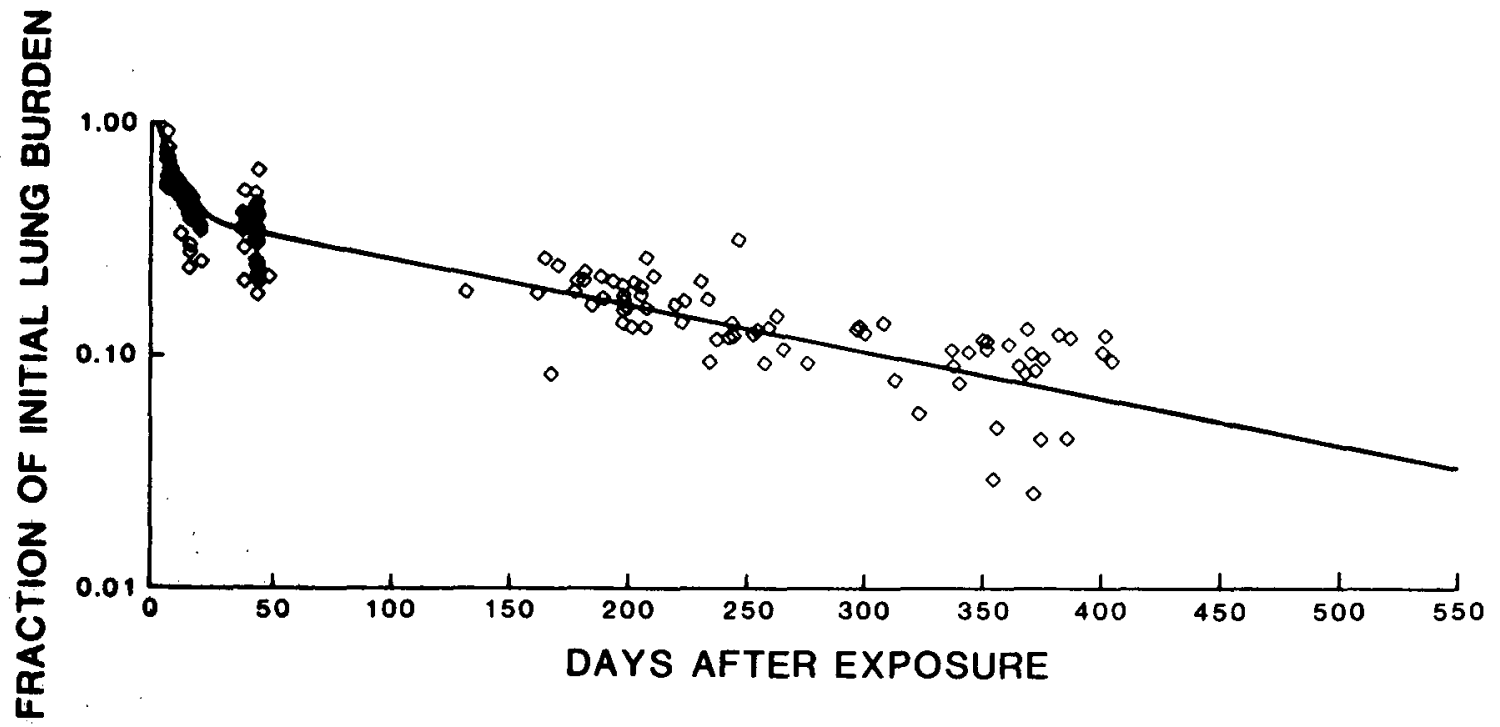

2.1 Pulmonary retention pattern for inhaled $147 \mathrm{Pm}$ in fused aluminosilicate particles.

\author{
$D R(t)=0.512 \bar{E} \star A(t) \star f / W(t), G y / d a y$
}

where

$\bar{E}=0.062 \mathrm{MeV}$ for ${ }^{147} \mathrm{Pm}$

$A(t)=$ the activity retained which equals the product of the initial activity times the lung retention function

$f$ = fractional energy absorption in the lung: 0.97 (based on Snipes, 1980)

$W(t)=$ lung weight in $g$ at $t$ days after inhalation exposure

$=0.005^{\star}\left[\right.$ Initial Weight $\left.(g)+124^{\star} G F(t)\right]$ for females

$=0.0041^{\star}$ [Initial Weight $(g)+166^{\star} G M(t)$ ] for males

where

$$
G F(t)=1-\exp \left(-0.0169 t_{t} 0.822\right)
$$

and

$$
\operatorname{GM}(t)=1-\exp (-0.0133 * t 0.938)
$$

The function $W(t)$ is based on weight of the control rats in the study with $0.5 \%$ of the female body weight being due to the lung weight and $0.41 \%$ being the lung weight percentage for mates (Lundgren, 1980). This function accounts for the increased size and weight of the lung as the rats mature. 


\subsubsection{Experimental Design}

Equal numbers of both sexes were randomly assigned to exposure groups as indicated in Table 2.1. Randomizations were constrained such that the average body weights were similar among a 11 exposure levels and groups for a given sex. "The rats were divided into groups that were exposed to aerosol concentrations of 147 Pm-FAP that were estimated to result in one-year mortalities of between 0 and $2 \%, 2$ and 25\%, 25 and $95 \%$, and 95 and 100\%. The desired average initial lung burdens are also given in Table 2.1. These estimates were based on the hazard function model for early mortality based on data from dogs that inhaled beta emitters (Hahn. 1979).

A wide range of desired initial lung burdens was chosen to bracket the estimated $0_{50}$ and provide rats in the high and low ranges of the dose-response curves where uncertainties are large. Animals in groups designated for hematology were bled periodically and were regarded as a separate group for analysis purposes.

Table 2.1

Experimental Design for Rats Exposed to $147 \mathrm{Pm}$ Inhaled

In Fused Aluninosilicate Particles

\begin{tabular}{|c|c|c|c|c|}
\hline Exposure & Range for Expected & Desired Initial & \multicolumn{2}{|c|}{ Number of Rats ${ }^{C}$} \\
\hline Group & Mortality $(\%)^{\mathrm{a}}$ & Lung Burden (MBq) ${ }^{b}$ & Mortality & Hema tology \\
\hline A & 0 & 0 & 30 & 10 \\
\hline B & $0-2$ & 1.7 & 50 & 10 \\
\hline C & $2-25$ & 2.8 & 70 & 10 \\
\hline 0 & $25-95$ & 3.2 & 40 & 10 \\
\hline \multirow[t]{3}{*}{ E } & $95-100$ & 4.4 & -40 & $-\underline{0}$ \\
\hline & & & 230 & 40 \\
\hline & & & Combir & $1=270$ \\
\hline
\end{tabular}

ane year mortality.

bone $\mathrm{MBq}=27 \mu \mathrm{C}$.

${ }^{C}$ Equal numbers of males and females in each group.

\subsection{RESULTS}

\subsubsection{Radiation Dose to Lung}

The' pulmonary dose accumulation function for inhaled $147 \mathrm{Pm}$ in fused aluminosilicate is plotted in Figure 2.2. One MBq of $147 \mathrm{Pm} / \mathrm{g}$ lung initial lung burden $=46$ Gy (4600 rad) at 365 days after inhalation or 53 Gy (5300 rad) at 900 days. The radioactive label 169 Yb contributed about $1 \%$ of the total dose to the lung. Estimates of cumulative rads to the lung at death for each rat are provided in the Appendix. Caution should be taken in using dose to death for analysis of dose-effect relationships because these doses represent random variables. To use doses to death, one must adjust for the fact that the doses are, in part, dictated by the death of the animals as well as the experimental design. Use of dose to death to form dose groups for dose-effect analysis can lead to results that are in error by several orders of magnitude when hundreds of animals are involved. In this report, cumulative doses to a specified time have been used in the analyses. 
Calculated cumulative doses to 900 days (approximate median life span for controls) are provided in the Appendix along with the 30 -day doses. The 30 -day dose is the basis upon which an early-effects mortality model has been developed at Pacific Northwest Laboratory (Filipy et al.. 1980). Given an initial lung burden and lung retention function, doses to a specified time can be calculated before an individual dies and therefore are more useful for making predictions than dose to death.

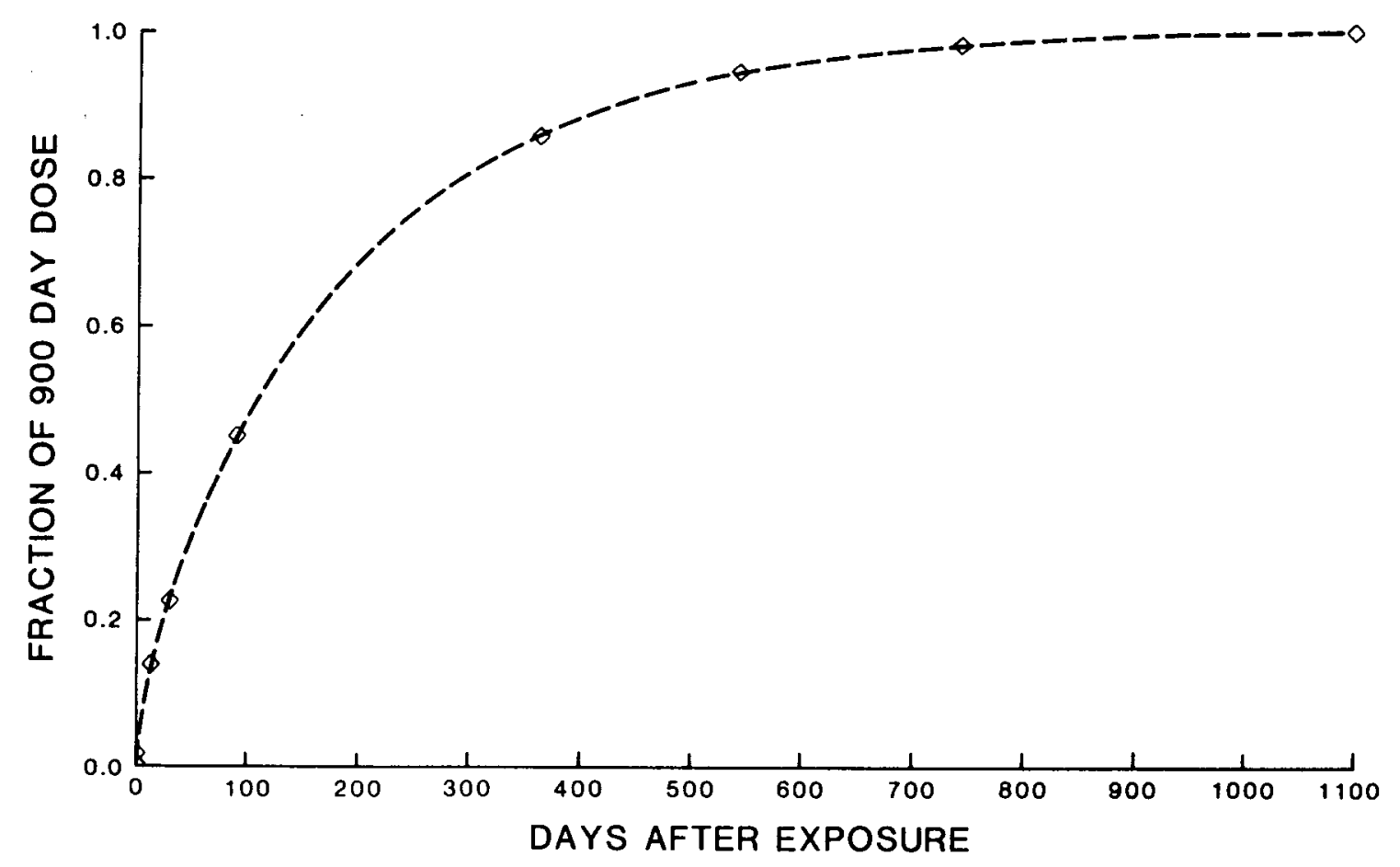

2.2 Calculated pulmonary dose accumulation pattern after inhalation of $147 \mathrm{Pm}$ in fused aluminosilicate particles.

\subsubsection{Survival Distribution}

Survival times for each rat were recorded to the end of the study period at 1.5 years after inhalation exposure and are plotted in figure 2.3 and given in the Appendix. The mean survival time was about 254 days. The original protocol called for observations to 1 year after exposure. However, $15 \%$ of the rats that died of radiation pneumonitis before 1 year died between 300 and 365 days after exposure. The observation period was, therefore, extended to ascertain the potential bias in risk estimates derived from limiting the observations to one year. During the first 365 days after exposure, 55 rats died; $95 \%$ of, these died of radiation pneumonitis and $5 \%$ had lung tumors. Between 365 days and 540 days after exposure, 43 rats died, 10 of radiation pneumonitis and pulmonary fibrosis and 25 of lung tumors. The survival distribution of the rats that died of radiation pneumonitis is shown in Figure 2.4 . 


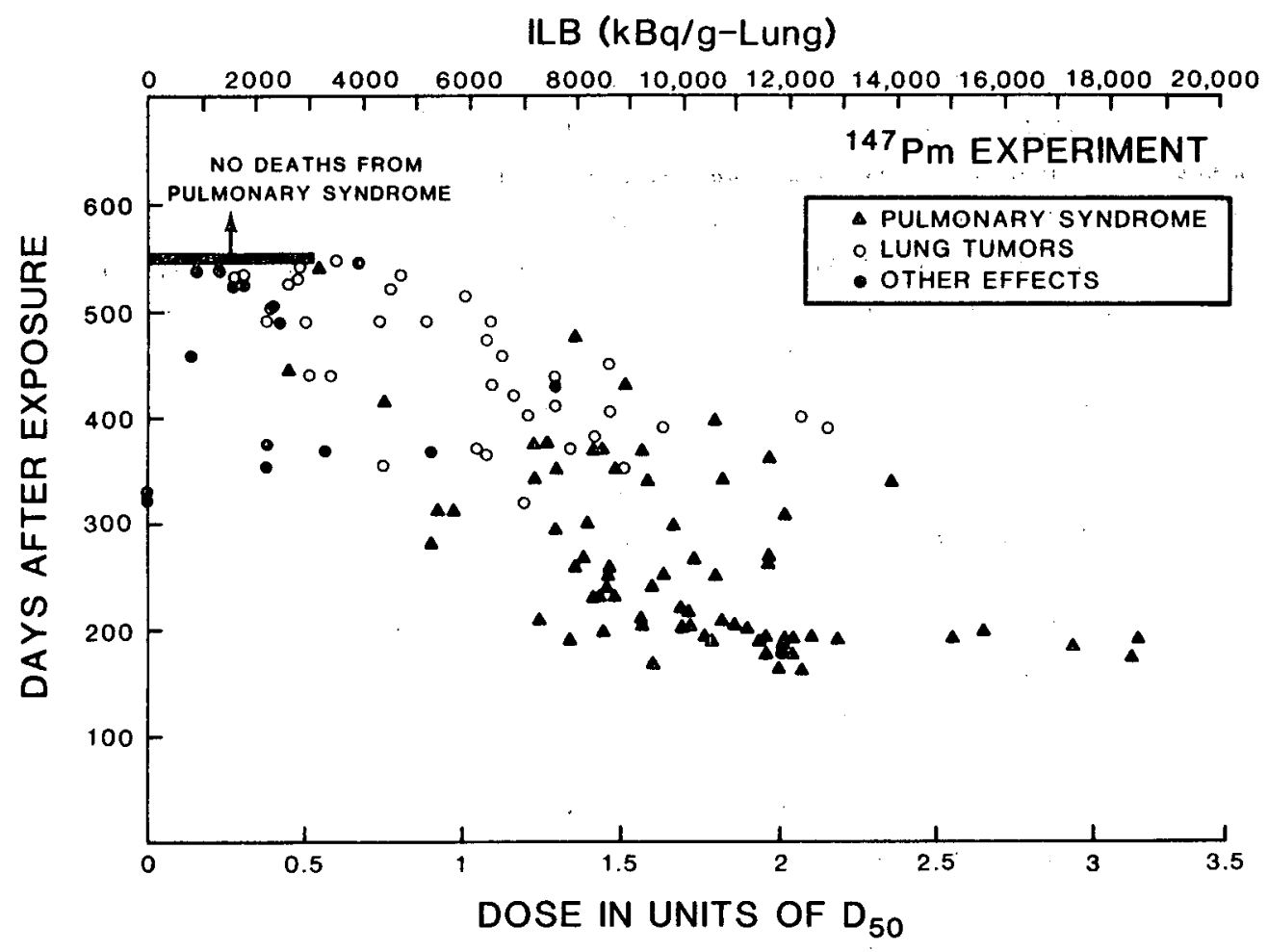

2.3 Time to death from radiation pneumonitis and its relation to initial lung burden after inhalation of $147 \mathrm{Pm}$ in fused aluminosilicate particles. Triangles represent time to death or euthanasia due to radiation pneumonitis. The horizontal bar represents survivors at the end of the study. Open circles represent lung tumors and closed circles represent other effects.

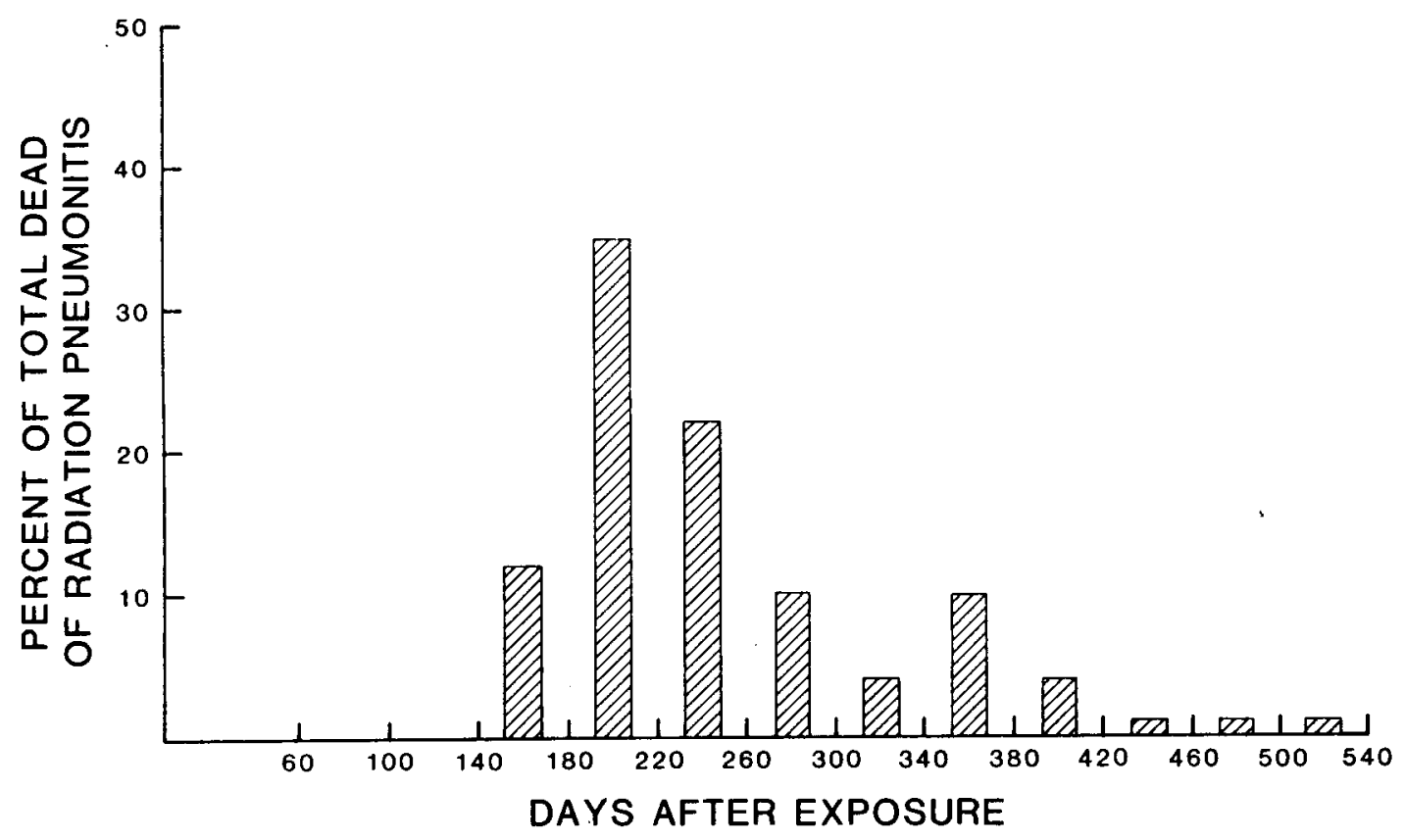

2.4 Distribution of survival times for rats dying of radiation pneumonitis and pulmonary fibrosis after inhalation of $147 \mathrm{Pm}$ in fused aluminosilicate particles. vertical ticks bracket the time intervals. 
Examination of the rats that died revealed several causes of death (see Appendix). The most prevalent cause was radiation pneumonitis and pulmonary fibrosis. It was characterized by increased numbers of vacuolated alveolar macrophages and occasional neutrophils, alveolar fibrosis, alveolar hemosiderin, vasculitis and fine alveolar septal fibrosis. Thrombosis was also present occasionally. Radiation pneumonitis and pulmonary fibrosis were considered the cause of death when these characteristics were found and there was no other obvious cause of death.

Primary lung tumors were also a major cause of death. Hemangiosarcomas and squamous cell carcinomas were the major types observed. One adenocarcinoma was found. The cause of death was determined by examination of each case and evaluation of the size and presence of metastasis of the tumor. Two leukemias that involved the lung were also found. They were not considered radiation-induced but were judged to be the spontaneous granular cell leukemia commonly seen in F344 rats.

The first rat to die with radiation pneumonitis died at 161 days after exposure with a dose to death of $390 \mathrm{~Gy}(39,000 \mathrm{rad})$. Two rats died before this time, one at 6 days after exposure and a second at 131 days after exposure. Neither of these deaths was judged related to the radiation exposure and the animals were excluded from all dose-effect analyses.

The death of the first rat with a lung tumor occurred 199 days after exposure with a dose to death of 430 Gy $(43,000 \mathrm{rad})$. Although this rat had two primary lung tumors, an hemangiosarcoma and a squamous cell carcinoma, radiation pneumonitis was considered the cause of death. The first rat to die with a lung tumor as the primary cause of death, died 322 days after exposure with a dose to death of 330 Gy $(33,000$ rad). The tumor type was hemangiosarcoma. The prevalences of tumors among all rats that died or were euthanized or sacrificed between 1 and 1.5 years after exposure that were submitted to histopathological examination are given in Table 2.2. Hemangiosarcomas were more prevalent in the higher dose groups compared to the prevalence of carcinomas.

Table 2.2

Number of Lung Tumors to 1.5 Years After Exposure in Rats Exposed by Inhalation to $147 \mathrm{Pm}$ in Fused Aluminosilicate Particles

\begin{tabular}{|c|c|c|c|c|c|c|c|c|}
\hline Number & Dose & Average & & & & & Total & Lung \\
\hline of & Range & Dose & Squamous & Hemangio- & Adeno- & other & Lung & Tumors \\
\hline Rats & $-(G y)^{a}$ & $(G y)^{b}$ & Carcinoma & Sarcoma. & Carcinoma & Tumors & Tumors & per $\operatorname{Rat}^{\mathrm{C}}$ \\
\hline 40 & $10-80$ & 40 & 1 & 0 & 0 & 0 & 1 & 0.025 \\
\hline 40 & $80-130$ & 100 & 3 & 3 & 0 & 0 & 6 & 0.75 \\
\hline 30 & $130-240$ & 160 & 1 & 6 & 1 & 0 & 8 & 0.27 \\
\hline 30 & $260-570$ & 360 & 6 & 13 & 0 & 3 & 22 & 0.73 \\
\hline
\end{tabular}

ane Gray $=100$ rad.

bone year doses to lungs.

$\mathrm{C}_{\text {No }}$ tumors observed among control rats. 


\subsubsection{Body Weight Data}

In analyzing body weight data, two plausible models were considered: (1) a constant weight-gain model, and. (2) a constant percentage weight-gain model. With both these models, body weight gain was negatively correlated with radiation dose and was uncorrelated with initial body weight. The data were examined to determine if percentage body weight gain or body weight gain were correlated with initial body weight. As shown in Figures 2.5. and 2.6, the percentage body weight gain for control females and males over a 10-week period after exposure was negatively correlated with the initial body weight. Similar results were obtained at all other times after exposure that body weights were recorded. The negative correlation indicates that the constant percentage weight-gain model is not a plausible model.

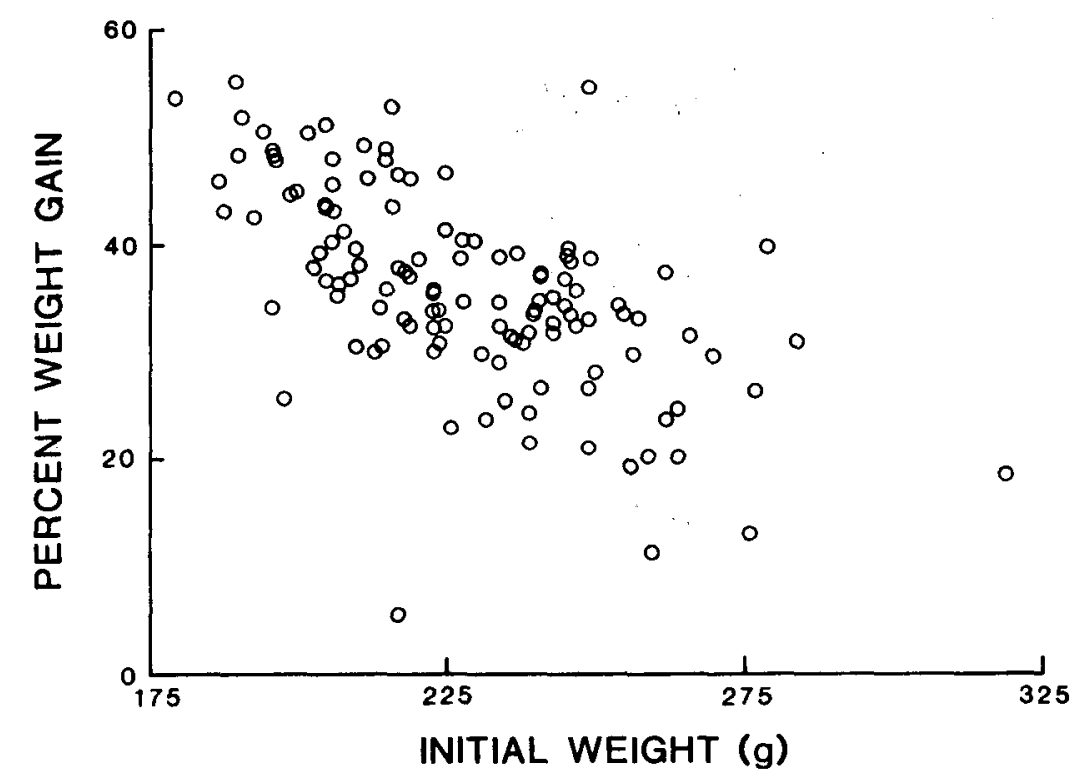

2.5 Percent body weight gain at 10 weeks after exposure vs initial weight for male control rats.

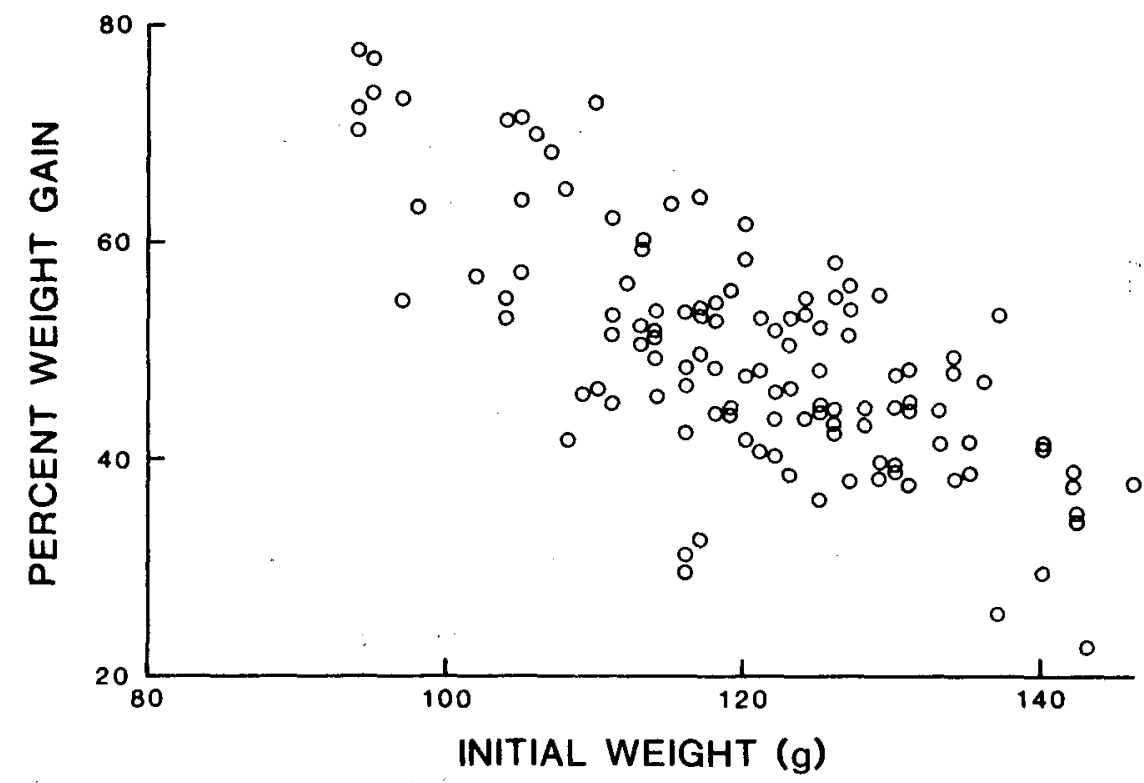

2.6 Percent body weight gain at 10 weeks after exposure vs initial weight for female control rats. 
A similar analysis was done for the constant weight-gain model. Figures 2.7 and 2.8 demonstrate that body weight gain at 10 weeks after exposure was not correlated with initial body weight for either sex. Similar results were obtained at all other times that weights were recorded. These results suggest that the constant weight-gain model is more plausible than the constant percentage weight-gain model. Therefore, only the constant weight-gain model was used in the analysis of body weight data.

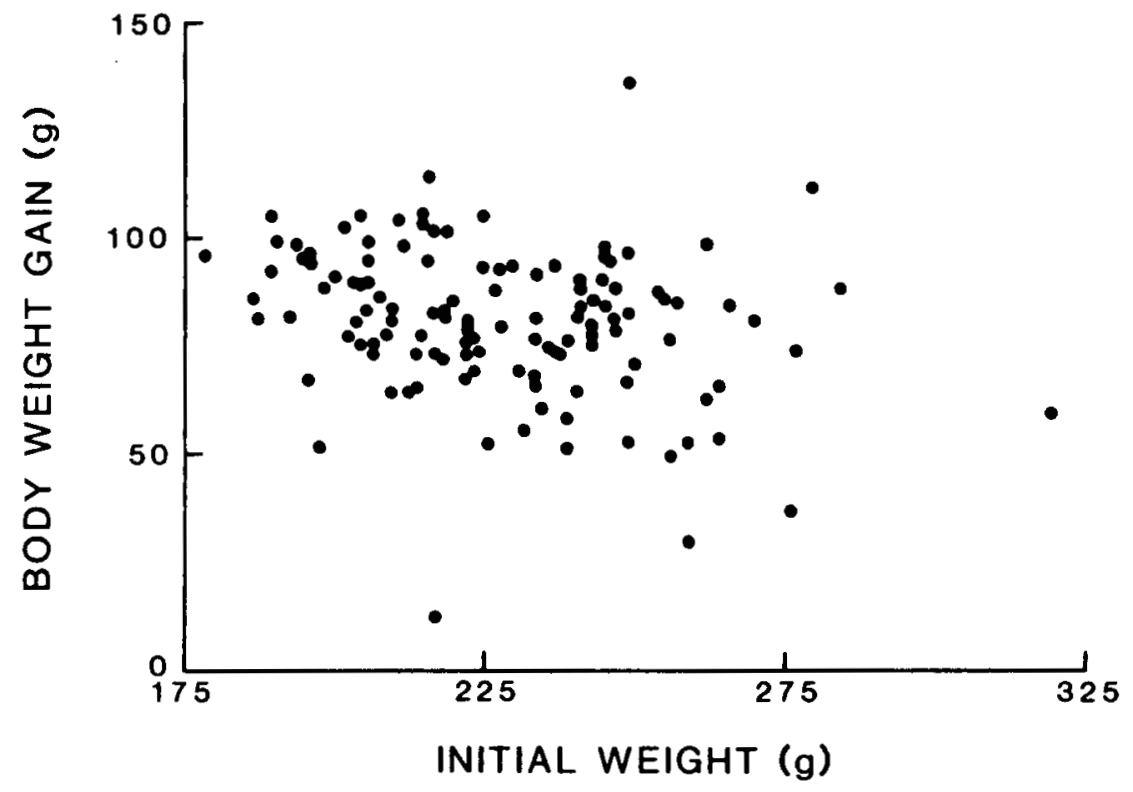

2.7 Body weight gain at 10 weeks after exposure vs initial weight for male control rats.

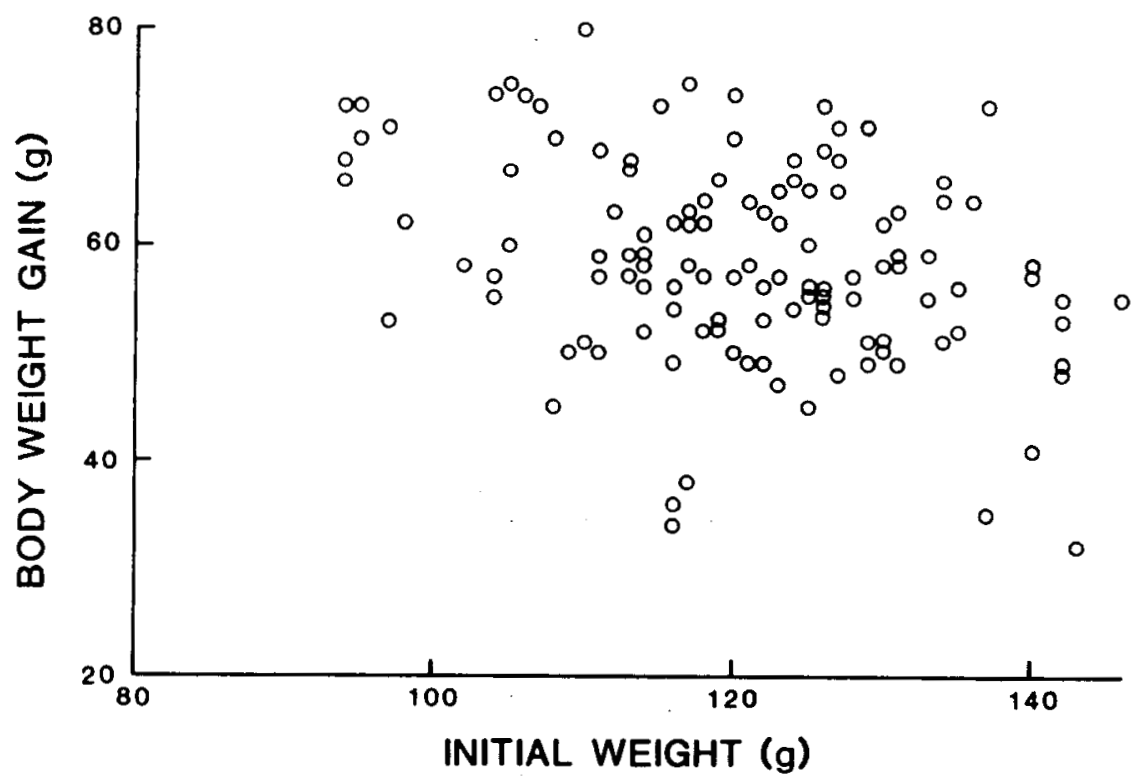

2.8 Body weight gain at 10 weeks after exposure vs initial weight for female control rats. 


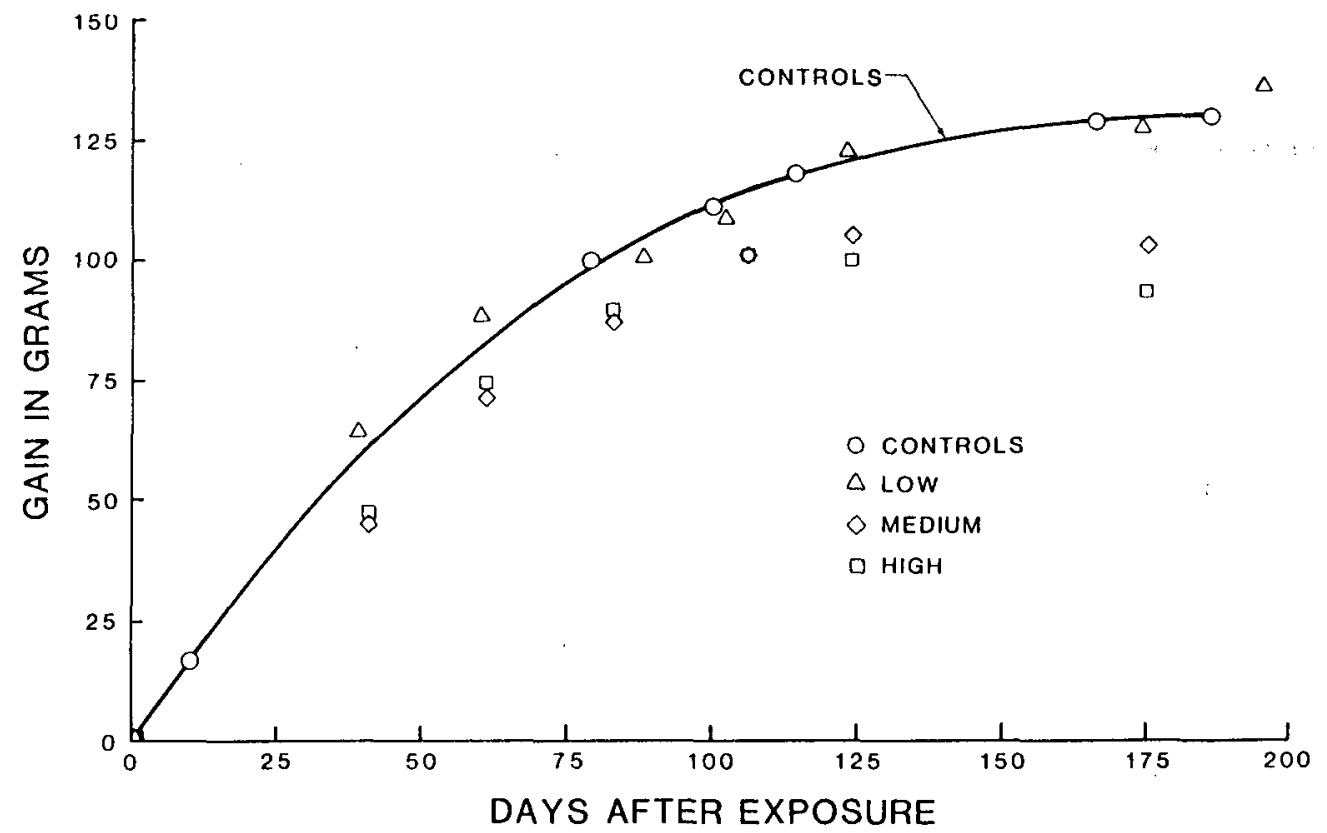

2.9 Body weight gain for male rats after inhalation exposure to $147 \mathrm{Pm}$ in fused aluminosilicate particles. Four groups are: controls, 10w, medium, and high that have doses in units of $\mathrm{D}_{50}$ of $0,0.003-0.44,0.44-1.2$ and $1.2-1.8$, respectively.

Body weight gain vs days after exposure for males and females assigned to specific dose groupings are plotted in figures 2.9 and 2.10. For males, the low, medium and high dose groups had initial lung burdens that ranged from 20-3100, 3100-8700, and $8900-12,900 \mathrm{kBq} / \mathrm{g} 1 \mathrm{ung}$, respectively. For females, the ranges were $70-3200,3900-8100$ and $8400-18,000 \mathrm{kBq} / \mathrm{g} 7 \mathrm{ung}$, respectively. For males, group-averaged initial lung burdens for the low, medium and high dose groups were 1700,6100 and $10,300 \mathrm{kBq} / \mathrm{g}$ lung, respectively. For females, the respective averages were 1600,6500 and $11,800 \mathrm{kBq} / \mathrm{g}$ lung. Reduced weight gains are present only for animals receiving lethal or nearly lethal doses (high and medium dose groups).

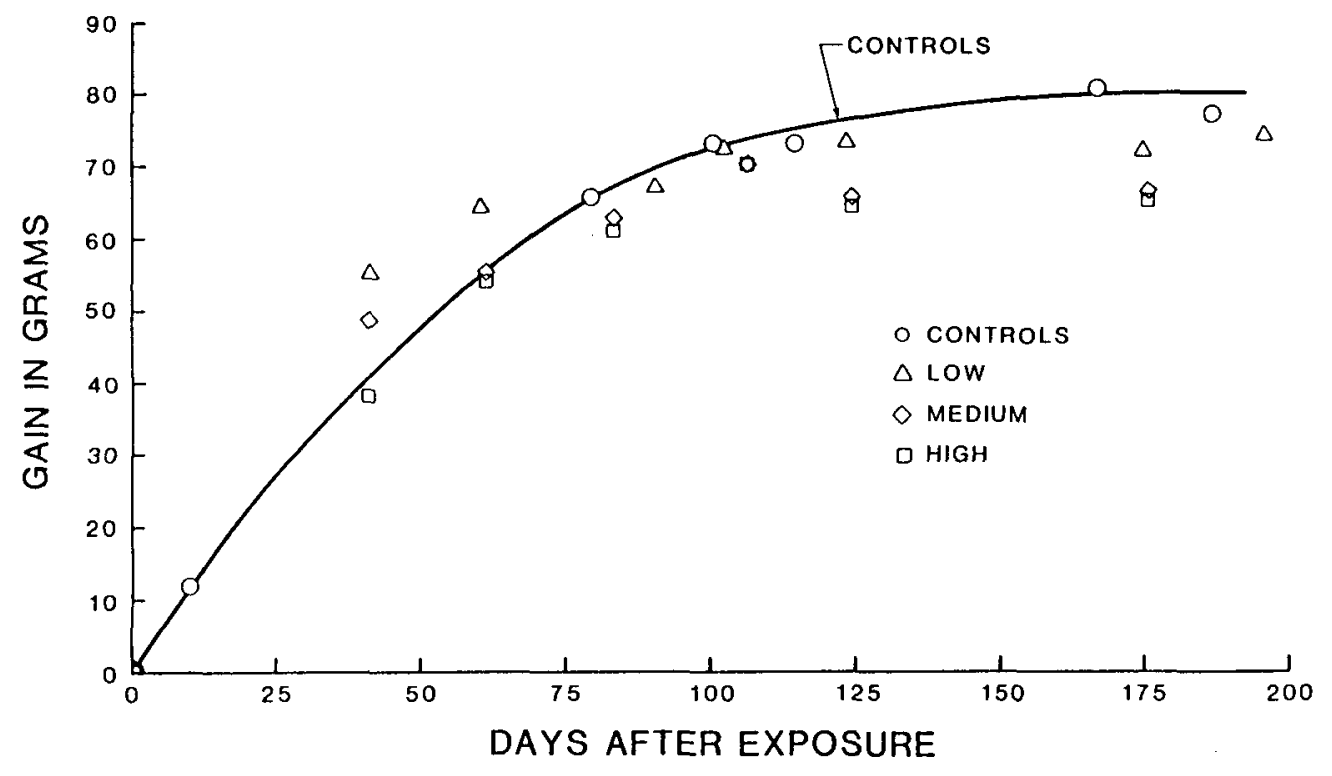

2.10 Body weight gain for female rats after inhalation exposure to $147 \mathrm{Pm}$ in fused aluminosilicate particles. Four groups are: controls, medium, and high that have doses in units of $D_{50}$ of $0.0 .017-0.70,0.83-1.7$ and $1.8-3.8$, respectively. 


\subsubsection{Hematological Data}

Hematological measurements were repeatedly performed on the same 20 males and 20 females assigned to the hematology group. Hematological measurements recorded before exposure and 7 , 14 , $30,60,90,180$, and 540 days after exposure included red and white blood cell concentrations, differential white cell counts, platelet concentration, hematocrit, and $\%$ hemoglobin concentration. Based on the $95 \%$ confidence interval for the correlation coefficient, none of the hematology measurements was significantly correlated with time after exposure or radiation dose to lung.

Plots of lymphocyte concentration vs time after exposure are given in figure 2.11 for low, medium and high dose groups as well as controls. For the low dose group, initial lung burdens ranged from 20 to $1300 \mathrm{kBq} / \mathrm{g}$ lung. For the medium dose group, initial lung burdens ranged from 1600 to $6300 \mathrm{kBq} / \mathrm{g}$ lung. For the high dose group, initial lung burdens ranged from 7500 to 13,600 $\mathrm{kBq} / \mathrm{g}$ lung. In these plots, no dose-related depression in lymphocyte concentration is apparent. These results indicate that low energy beta emissions from ${ }^{147} \mathrm{Pm}$ in rat lungs are insufficient to cause detectable injury to the hematopoietic system.

2.3.5 Mortality Data

Risk estimators have been developed for lethality from radiation pneumonitis during the first 1.5 years after exposure. Only individuals listed in the Appendix as having radiation pneumonitis as the major finding at death were considered as dying from radiation pneumonitis.

A maximum likelihood procedure was used in the analysis because data from individual rats, rather than groups of rats, could then be used (SAS, 1982). This eliminated the systematic error associated with forming dose groups which generaliy leads to underestimating the slope of the dose effect curve.

A Weibull-type risk function has been used to describe lethality. It can be characterized by the median lethal dose, D50, and shape parameter, $V$ (Scott and Hahn, 1985). With the Weibull model, the cumulative hazard $H$ is related to the lethality risk, $R$, by

$$
R=1-\exp (-H)
$$

where

$$
H=\ln (2) *\left[0 / 0_{50}\right]^{V} \text {. }
$$

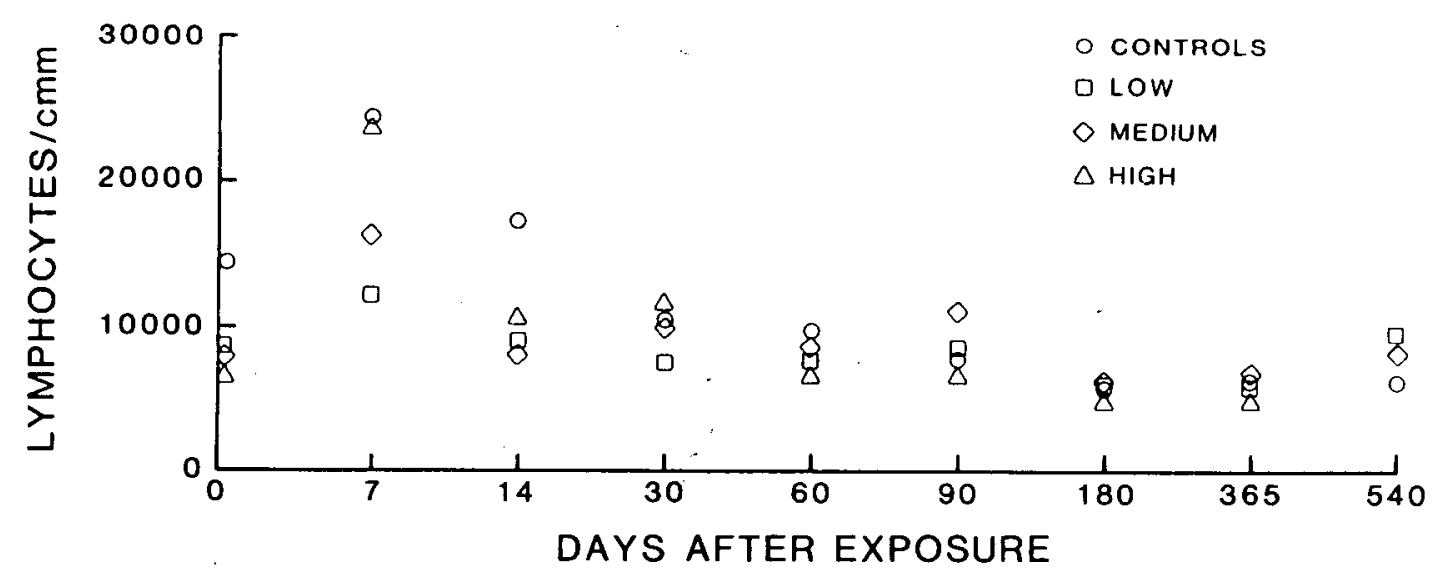

2.11 Lymphocyte concentration after inhalation exposure (males and females combined): low = D50 units of $0.003-0.22$, moderate $=0_{50}$ units of $0.26-1.1$, high $=0_{50}$ units of $1.3-2.3$. 
The variable $D$ is the radiation dose evaluated to a specified time and $D_{50}$ is in the same units as D. The time chosen to which the doses would be calculated was the median survival time of the control animals (900 days). This calculation yields a dose that is essentially the same as the potential infinite dose to the lungs. However, the median lethal dose in terms of $\mathrm{kBq} / \mathrm{g}$ lung initially deposited in the lung (ILB's), as well as the shape parameter, was first estimated. This value was then converted to the appropriate radiation dose in Gy. This eliminated the systematic error contribution to the shape parameter estimate that arises from errors in the dose accumulation curve. The median lethal initial lung burden was $5900 \pm 180 \mathrm{kBq} / \mathrm{g}$, lung. This corresponds to a 900-day dose of $310 \pm 11$ Gy (31,000 rad) to the lung. The shape parameter (or slope) $V$ was estimated to be $5.4 \pm 0.9$. A graphic illustration of the shape of the curve described by these parameters is shown in figure 2.12 .

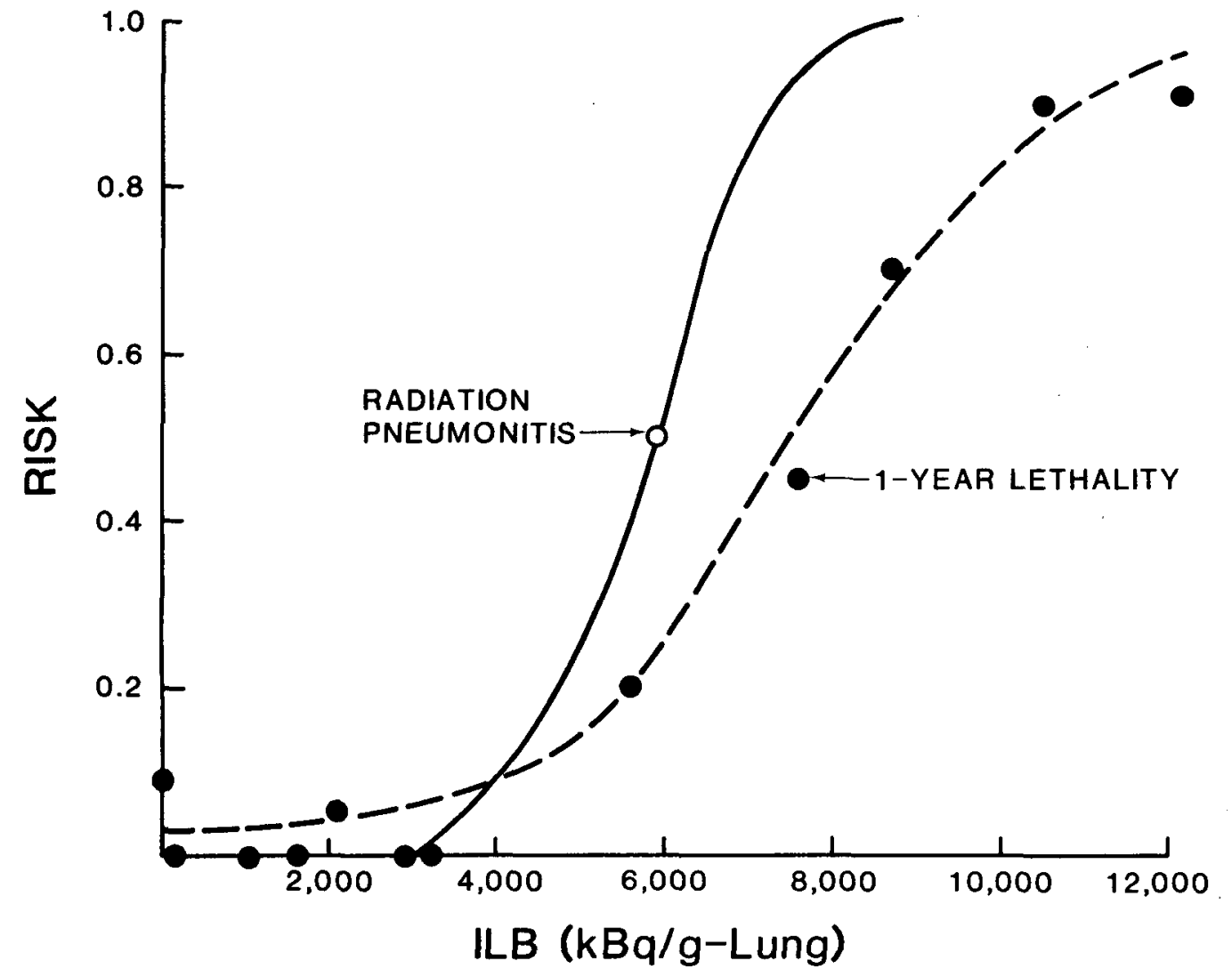

2.12 Dose-response curve for death from radiation pneumonitis after inhalation of $147 P_{m}$ in fused aluminosilicate particles by rats. 


\subsection{DISCUSSION}

This study demonstrates that, while low-energy beta irradiation from $147 \mathrm{Pm}$ deposited in the lung caused deaths from radiation pneumonitis and pulmonary fibrosis, it did not cause a reduction in peripheral blood cell counts when the radioactivity was mainly localized in the lung. These results indicate that injury to the hematopoietic system due to beta radiations transversing from the lung to the bone marrow or blood was not significant enough to reduce peripheral blood counts.

Changes in body weight were evaluated as an indicator of iliness or morbidity. The results show that body weight is a poor choice as an indicator of morbidity in the nonlethal dose range. Effects on body weight were observed mainly in animals within the lethal dose range.

The prevalence of lung tumors among rats that died or were euthanized or sacrificed between 1 and 1.5 years after inhalation exposure and submitted for histopathological evaluation was analyzed in terms of the calculated cumulative dose to 1 year (Table 2.2). The total prevalence of lung tumors per rat increased monotonically from 0.025 at an average dose of 40 Gy (4000 rad) to 0.73 at an average dose of 360 Gy $(36,000 \mathrm{rad})$. This means that a 9 -fold increase in dose was associated with an approximate 30 -fold increase in tumor prevalence over the dose range considered and is indicative of a nonlinear dose-effect relationship. Because of the known inverse relationship between time to tumor occurrence and radiation dose, the observation of a nonlinear relationship for tumor-prevalence vs dose for the 1 to 1.5 year time interval does not rule out the possibility of a linear relationship for the tumor prevalence at a longer time after exposure.

\subsection{SUMMARY}

This chapter of the report describes data for early mortality and morbidity among rats exposed via inhalation to the low-energy beta emitter $147 \mathrm{Pm}$. The purpose of the $147 \mathrm{Pm}$ experiment was to provide a reference data set to be used with the results discussed in chapter 3 for the high-energy beta emitter $90 \mathrm{Sr}$ to determine if significant injury to the hematopoietic system occurs from high-energy beta emitters deposited and remaining in the lung. The 147Pm was delivered via inhalation of an insoluble fused aluminosilicate particle matrix that also contained a small amount of ${ }^{169} \mathrm{Yb}$ as tracer to determine retention of the particles in the lung. Changes in lung weights with time after exposure were taken into consideration in evaluating radiation doses to the lung. The lungs of irradiated rats were assumed to have the same growth curve as did the unirradiated controls.

No effects were observed on the peripheral blood of irradiated rats. This indicates that cross-organ irradiation effects are not likely to be significant after inhalation exposure of rats to $147 \mathrm{Pm}$ when inhaled in an insoluble aerosol. Cross-organ irradiation effects in larger species would be even less.

It was demonstrated that body weight was a poor choice for indicating morbidity in the sublethal dose range. Significant effects on body weight were observed only in rats in the lethal dose range.

While no lung tumors were induced in control rats, a spectrum of primary lung tumors were produced in irradiated rats. Most prevalent were hemangiosarcomas, followed by squamous cell carcinomas. The prevalence of lung tumors among rats that died or were euthanized or sacrificed between 1 and 1.5 years after inhalation exposure increased with dose, but in a nonlinear fashion. 

CHAPTER 3

THE INFLUENCE OF RADIATION DOSE RATE PATIERN ON EARLY EFFECTS IN THE LUNG

\subsection{INTRODUCTION}

This chapter describes morbidity and mortality data developed from rats that inhaled mixtures of $90 \mathrm{Sr}$ and $90 \mathrm{Y}$ in fused aluminosilicate particles. Three experiments were conducted, each with aerosols of different mixtures of $90 Y+90 \mathrm{sr}$ that yielded different temporal beta irradiation patterns of the lung. Biological data obtained included hematology, body weight, pulmonary function, survival time and likely cause of death that can be used to develop morbidity and validate mortality models.

Exposure of rat lungs to beta radiation from mixtures of $90 \mathrm{Y}+90_{\mathrm{Sr}}$ inhaled in fused aluminosilicate particles leads to a complex dose rate pattern to the lung. In Phase I, a model was developed that allows the prediction of the lethality risk for deaths from radiation pneumonitis when exposed to complex dose rate patterns. The mortality data described in this chapter will be used to test the mortality model.

\subsection{METHOOS}

\subsubsection{Animals and Animal Maintenance}

Equal numbers of male and female $F 344 / C r l$ rats were exposed by inhalation when they were approximately $15 \pm 2$ weeks of age. They were obtained from the breeding colony of the lovelace Inhalation Toxicology Research Institute. Before exposure, members of each sex were weighed, ear tagged and housed separately, 2 per cage, in polycarbonate cages $(25 \times 48 \times 20 \mathrm{~cm}$ high $)$ with hardwood chip bedding and filter caps. The room housing the rats was maintained at 68 to $72^{\circ} \mathrm{F}$ and the relative humidity was maintained at 20 to $50 \%$. A 12-hour-on. 12-hour-off light cycle was used. Rats were fed (Lab Blox. Allied Mills, Chicago, IL) and given water ad libitum. After inhalation exposure the animals were returned to their quarters and maintained in a similar fashion.

\subsubsection{Biological Measurements}

Hematological measurements were recorded before exposure and at $7,14,30,60,90,180$ and 360 days after exposure for rats in the hematology groups. Hematological determinations included the red and white blood cell concentrations, differential white blood cell counts and the hematocrit. The rats were bled from the retrobulbar sinus. Blood smears were made and the blood diluted in Unopettes $\odot$. Blood cell concentrations were performed with an electronic blood cell counter (Coulter S550).

Rats in all groups were weighed one week before exposure and on weeks $2,4,6,8,10$ and then once a month thereafter to one year.

Pulmonary function measurements were made on a predesignated group of 90 Sr-exposed rats at 1-2 weeks before exposure and $60,90,180,270,360$ and 540 days after exposure. In addition, 48 surviving rats in the mortality group exposed to $90 \mathrm{Y}$ FAP were tested at 1.5 years after inhalation exposure. The function measurements determined were breathing patterns, dynamic mechanics, diffusion capacity, maximum expiratory flow, quasistatic compliance of lung and lung volume. Measurements were made with a 1.5-liter combination flow (volume displacement) and pressure (constant volume) plethysmograph using procedures previously published (Harkema et al., 1982 and Mauderly, 1982).

\subsubsection{Aerosol Preparation And Generation}

The stock suspensions used for aerosol generation were prepared by cation exchange of the radionuclide or radionuclide mixture of interest into montmorillonite clay. For the $90_{S r}$ aerosol generator stock solution, an equilibrium mixture of $90 \mathrm{Sr}$ and $90 \mathrm{y}$ was exchanged and a 10 day period 
was used to achieve equilibrium. This was necessary because of a higher exchange specificity of day for the $\left[\gamma^{+3}\right]$ cations versus the $\left[S r^{+2}\right]$ cations. For the $90 y$ generator stock solution, pure $90 Y$ was exchanged into the clay. The $90 Y$ was obtained by preparing and filtering an yttrium hydrogen phosphate colloidal suspension from $90 \mathrm{Sr}$, in secular equilibrium with $90 \mathrm{Y}$, on the day of exposure. For the combined $90 \mathrm{Sr}$ and $90_{Y}$ aerosol generator stock solution, pure $90 \mathrm{Y}$ was prepared on the day of exposure and added to $90 \mathrm{Sr}$ (in secular equilibrium with $90 \mathrm{Y}$ ) to achieve a $90 \mathrm{Y}: 90 \mathrm{Sr}$ radioactivity ratio of approximately $3: 1$. The concentration of radionuclide in the clay was adjusted by adding unlabeled clay as necessary to produce an aerosol that yielded the desired initial lung burdens.

The aerosols were generated from the stock solution using an air flow rate of $1.5 \mathrm{Lpm}$ through a Lovelace nebulizer, passed through a heating column at $1100^{\circ} \mathrm{C}$, diluted with clean air and directed into the exposure chamber using a total volume flow rate of $20 \mathrm{Lpm}$.

Nose-only exposures were done using an 80-port small animal exposure chamber. Cascade impactor, filter, and electrostatic precipitator (ESP) samples were taken at the beginning and near the end of each exposure; these samples were used to determine physical characteristics of the aerosols and the aerosol radioactivity during inhalation exposure.

The particle size distribution was lognormal with an activity median aerodynamic diameter of approximately $2 \mu \mathrm{m}$ and and geometric standard deviation of approximately 1.5 to 2.0 .

3.2.4 Whole-Body Counting Procedures

Shielded $\mathrm{NaI}(\mathrm{T})$ crystal counters were used to detect the Bremsstrahlung radiation from $90 \mathrm{Sr}$ deposited in the rats. One- or two-minute whole-body counts were made immediately after inhalation exposure and on 3,4,5,6,7 and 8 days after exposure. Thereafter, rats were counted at monthly intervals. Appropriate reference standards were used including a counting phantom that simulated a typical lung burden in a rat.

3.2.5 Determination of Lung and Bronchial Lymph Node Radioactivity

The ${ }^{90} \mathrm{sr}$ contents of the lung and bronchial lymph nodes were determined on animals that died or were euthanized during the observation period and those sacrificed at the end of 1.5 years. At necropsy, whole-body, lung and bronchial lymph node weights were taken. Fixed lung and lymph node tissue remaining after sampling for histopathology were wet-ashed, sampled in triplicate and counted using liquid scintillation techniques to determine the content of $90 \mathrm{Sr}$. Corrections were made for quench using external standards and for loss of tissue sampled for histopathology.

3.2.6 Estimation of Initial Lung Burdens

3.2.6.1 Rats Exposed to ${ }^{90} \mathrm{Sr}$

Initial lung burdens of $90 \mathrm{Sr}$ were estimated from the measurements of whole-body activity of $90 \mathrm{Sr}$ at various times after inhalation exposure. To determine what percentage of the whole-body burden was in the lung, two rats (one male and one female) were sacrificed on the day of exposure and two (one male and one female) were sacrificed at 5 days after exposure and analyzed radiochemically. At 5 days after exposure, $79 \%$ of the body burden of $90 \mathrm{Sr}$ was in the lung. Based on an exploratory data analysis, it was judged that the ${ }^{90} \mathrm{Sr}$ in the lung at 5 days was more representative of the counting data taken 4 to 8 days after exposure than the $90 \mathrm{Sr}$ found in the lung of the rats sacrificed immediately after exposure. Assuming $79 \%$ of the total body burden at 4 to 8 days after exposure to be in the lungs, initial lung burdens were estimated by extrapolating back to the day of exposure using the same procedure that was used for $147 \mathrm{Pm}$. The initial lung burden estimates obtained for each rat in this way are given in the Appendix.

3.2.6.2 Rats Exposed to $90 y$

Initial lung burdens were estimated by first estimating the 90y initial lung

burden based on whole-body counts at early times when $90 \mathrm{Y}$ was still present. From radioactive decay measurements on the filters collected during exposure, it was determined that $2.3 \%$ of the 
initial activity in the lung was due to $90 \mathrm{Sr}$ carried over when the $90 \mathrm{Y}$ stock generator solution was prepared. The fraction of the total-body activity at early times $T$ (in days) that was due to $90 y$ was estimated using

Fraction $=0.977 \exp (-0.26 \mathrm{~T}) /[0.023+0.977 \exp (-0.26 \mathrm{~T})]$.

Multiplying the above fraction by 0.79 and multiplying the whole-body activity (determined from whole-body counting) at time $T$ by the product gave the estimated $90 Y$ activity in the lung. Initial lung burdens of $90 \mathrm{Y}$ were estimated by correcting for biological clearance and physical decay of $90 \%$.

Initial lung burdens of $90 \mathrm{Sr}$ were estimated based on $2.3 \%$ of the initial activity being due to $90 \mathrm{Sr}$ and the remaining $97.7 \%$ due to $90 \mathrm{Y}$. The $90 \mathrm{Sr}$ initial activity in the 1 ung was estimated by multiplying the $90 \mathrm{Y}$ initial activity by 0.023 . The total activity $(90 \mathrm{Y}+90 \mathrm{Sr})$ initially in the lung was approximately equal to the $90 \mathrm{Y}$ initial activity.

3.2.6.3 Rats Exposed to $90 Y+90 S r$

Initial lung burdens were estimated by first estimating the 90 sr initial lung burden based on whole-body counts at intermediate times when $90 y$ decay was essentially completed. Using whole-body counting data, and correcting for biological clearance, physical decay, and percent of total activity not in lung $(21 \%)$, initial lung burdens of $90 \mathrm{sr}$ were estimated by extrapolating back to the time of exposure.

Initial lung burdens for $90 y$ were then estimated based on $75 \%$ of the initial activity in lung being due to $90 Y$ and $25 \%$ due to $90 \mathrm{Sr}$. Thus the $90 \mathrm{Y}$ initial activity was obtained by multiplying the ${ }^{90} \mathrm{Sr}$ initial activity by 3 . The estimated total activity initially in the lung was therefore 4 times that for $90 \mathrm{sr}$.

3.2.7 Experimental Design

The experimental designs for the exposures to the three combinations of $90 \mathrm{Sr}$ and $90 \mathrm{Y}$ are presented in Tables 3.1, 3.2 and 3.3. Equal numbers of males and females were randomly assigned to each designated group. For the rats exposed to $90 \mathrm{Sr}$ only (Table 3.1) three separate groups of rats were designated: mortality, hematology and pulmonary function. The rats in the mortality group were weighed peiodically and observed twice daily for sickness or death for 1.5 years after exposure. Rats in the hematology group were bled periodically for hematology tests as well as being weighed and observed. Rats in the pulmonary function group were tested periodically for pulmonary function in addition to being weighed and observed. The hematology and pulmonary function groups were maintained as distinct groups so that any bias in the survival time or incidence introduced by the increased handing and the testing procedures could be determined.

The numbers of rats needed to yield signifiçant results were determined from response-probạility estimates shown in Table 3.4 (Crow et al.. 1960). For studies of hematologic changes the number per graup (10) was a compromise among the number necessary for valid statistics (6 per group), the number that could be processed per day and the probability of the number decreasing with time as the rats die of early effects. For studies of pulmonary functional changes, groups of 20 were chosen based on analysis of pulmonary functional abnormalities in dogs after inhalation of $144 \mathrm{Ce}$ in fused aluminosilicate particles (Mauderly et al., 1980).

The initial lung burdens desired were chosen to give $1 \%, 50 \%$ and $99 \%$ chance of survival to 1.5 years after inhạlation exposure. A wịde range of doseș was choșen for two primary reasons. First, the low and high ends of the dose-response eurve are the regions of most uncertainly, thus more information is needed there. Second, with inhalation exposure of a group of animals, a range of initial lung burdens results that span the desired initial lung burden by a factor of at least two. The range of initial lung burdens is due to different pulmonary depositions and retentions in the group of animals as well as some variations in aerosol concentrations at different points in the exposure chamber. 
Table 3.1

Experimental Design for Rats Exposed by. Inhalation to $90 \mathrm{Sr}$ In Fused Aluminosilicate Particles

\begin{tabular}{|c|c|c|c|c|c|}
\hline \multirow{3}{*}{$\begin{array}{l}\text { Exposure } \\
\text { Group }\end{array}$} & \multirow{3}{*}{$\begin{array}{l}\text { Desired Initial } \\
\text { Lung Burden (MBq) }\end{array}$} & \multirow{3}{*}{$\begin{array}{l}\text { Calculated } \\
\text { Initial Dose } \\
\text { Rate to Lung- } \\
\text { Gy/Dayb } \\
\end{array}$} & \multicolumn{3}{|c|}{ Number of Rats ${ }^{c}$} \\
\hline & & & & & Pulmonary \\
\hline & & & Mortality & Hematology & Function \\
\hline LOO (Controls) & 0 & 0 & 40 & 10 & 20 \\
\hline L01 & 0.15 & 0.70 & 40 & 10 & 20. \\
\hline L50 & 0.67 & 3.10 & 40 & 10 & 20 \\
\hline \multirow[t]{3}{*}{ L99 } & 0.93 & 4.30 & 40 & $1 \underline{0}$ & $\underline{20}$ \\
\hline & & & 160 & 40 & 80 \\
\hline & & & & \multicolumn{2}{|c|}{ Combined Total $=280$} \\
\hline
\end{tabular}

ane $\mathrm{MBq}=27 \mu \mathrm{Ci}$.

bone Gray $=100$ rad.

CEqual numbers of males and females in each group.

Table 3.2

Experimental Design for Rats Exposed by Inhalation to $90 Y$

In Fused Aluminosilicate Particles

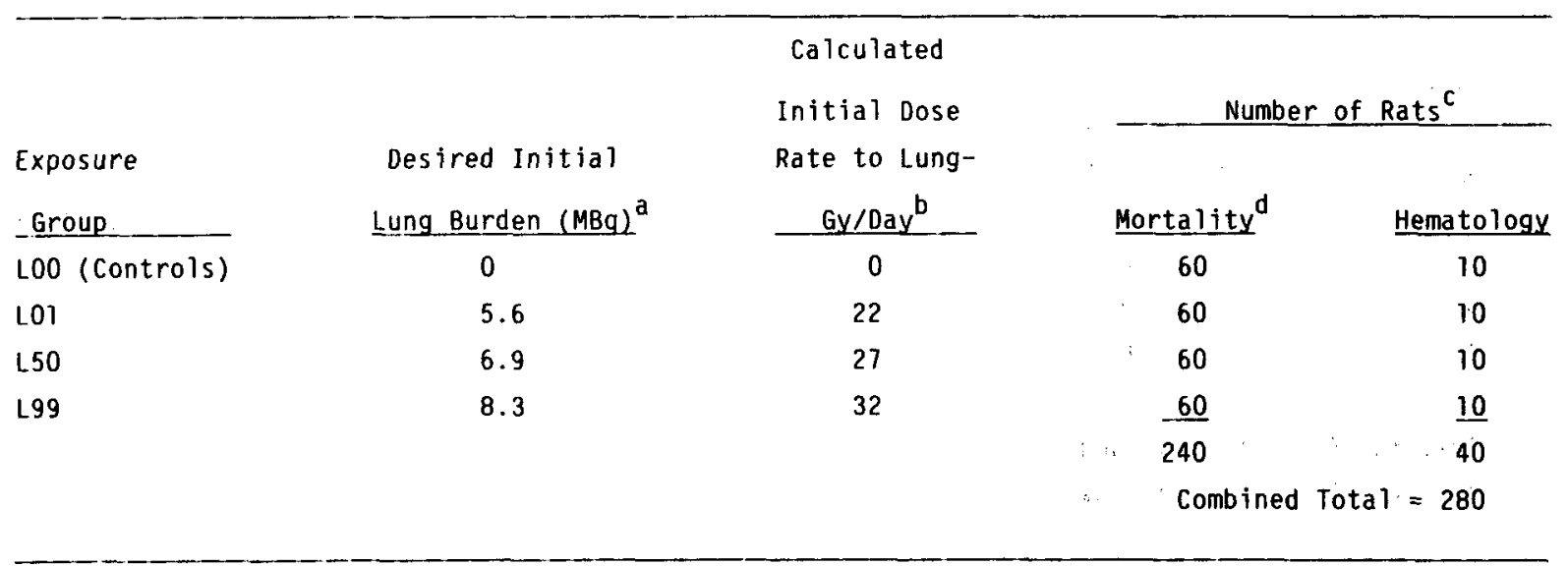

ane $\mathrm{MBq}=27 \mu \mathrm{Ci}$.

bone Gray $=100 \mathrm{rad}$.

$C^{C}$ Equal numbers of males and females in each group.

$d_{A t}$ the end of the study, 48 survivors were subjected to pulmonary function testing. This included 6 control males and 6 control females. 
Table 3.3

Experimental Design for Rats Exposed by Inhalation to $90 \mathrm{Sr}+90_{Y}$

In Fused Aluminosilicate Particles

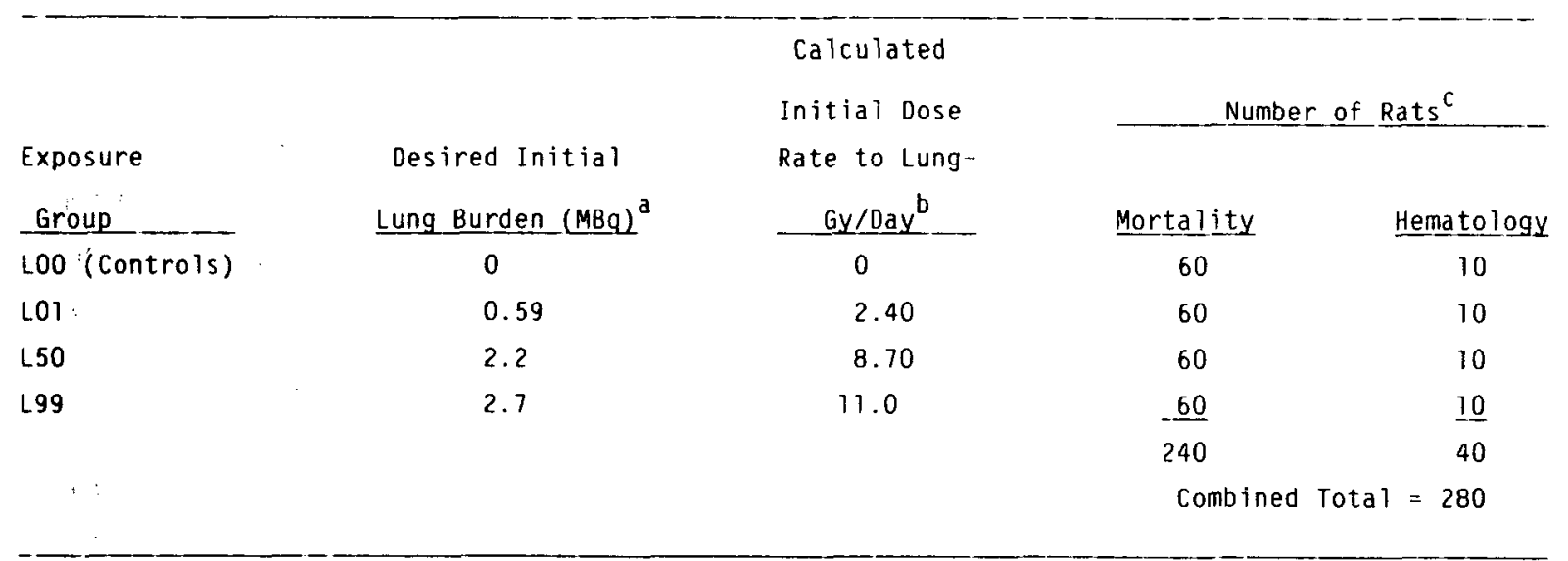

ane $\mathrm{MBq}=27 \mu \mathrm{Ci}$.

bone Gray $=100 \mathrm{rad}$.

CEqual numbers of males and females in each group.

Table 3.4

Response Probability Estimates for 20,30 or 50 Rats Per Group

\begin{tabular}{|c|c|c|c|c|}
\hline \multirow[t]{2}{*}{ Dose } & \multirow[t]{2}{*}{$\begin{array}{l}\text { Theoretical } \\
\text { Effect Probability }\end{array}$} & \multicolumn{3}{|c|}{$\begin{array}{l}\text { 95\% Confidence Range of Expected Probability } \\
\text { for Various Group Sizes }\end{array}$} \\
\hline & & 20 Rats & 30 Rats & 50 Rats \\
\hline D01 & 0.01 & $<0.14$ & $<0.05$ & $<0.05$ \\
\hline 050 . & 0.50 & $0.29-0.71$ & $0.32-0.68$ & $0.35-0.65$ \\
\hline 099: & 0.99 & $>0.86$ & $>0.95$ & $>0.95$ \\
\hline
\end{tabular}

Values for 001 represent upper bounds.

Values for D9g represent lower bounds. 
Because of the variability in initial lung burdens, analysis of the data with animals placed in discrete groups before exposure is difficult. Therefore, analysis was done by determining doses for each animal and regrouping into dose groups or treating each animal individual in dose-response analyses.

The experimental design for the rats exposed to $90 y$ only is shown in Table 3.2. Only two groups of rat's were designated, mortality and hematology. However, at the end of the 1.5 year observation period 48 surviving rats were subjected to pulmonary function testing. This differs from the rats exposed to $90 \mathrm{Sr}$ since sequential data was not obtained in the $90 \mathrm{r}$ study.

The experimental design for the rats exposed to $90 \mathrm{Y}$ mixed with $90 \mathrm{Sr}$ is shown in Table 3.3 . No pulmonary function testing was done on these rats.

\subsection{RESULTS}

3.3.1 Radiation Doses to Lung

3.3.1.1 Rats Exposed to $90 \mathrm{Sr}$

An exploratory data analysis revealed that for animals with initial lung burdens below that which killed $50 \%$ of those exposed $\left(D_{50}=1170 \mathrm{kBq} / \mathrm{g}\right.$ lung), the retention of radioactivity in lung was adequately represented by the retention function given by

Retention, low level $90 \mathrm{Sr}=0.58 \exp (-0.15 \mathrm{~T})+0.42 \exp (-0.0046 \mathrm{~T})$

where $T$ represents days after exposure. However, animals with lung burdens equal to or greater than the $\mathrm{D}_{50}$ had increased retention of radioactivity in the lung (based on animals dying in the study at early times and radiochemical analysis of their lung); for these animals, retention of radioactivity in lung was adequately represented by the single exponential

Retention, high level $90 \mathrm{Sr}=\exp (-0.006 \mathrm{~T})$,

where $T$ represents days after exposure.

The cumulative radiation doses to the lung to death or doses to a specified time were determined by numerical integration over the dose rate pattern for each exposed individual. Instantaneous dose rates $D R(t)$ at any given $t i m e, t$, were given by

$$
D R(t)=0.512 \bar{E}^{\star} A(t) * f / W(t), \text { Gy/day }
$$

where

$\bar{E}=1.13 \mathrm{MeV}$ for an equilibrium mixture of ${ }^{90} \mathrm{Sr}$ and ${ }^{90} \mathrm{Y}$

$A(t)=$ the activity retained which equals the product of the initial activity times the lung retention function

$f=$ fractional energy absorption in lung $=0.3$ (based on Snipes, 1980)

$w(t)=$ lung weight $(g)$ at $t$ days after inhalation exposure

$=0.005^{\star}[$ initial lung weight $(g)+124 \times G F(t)]$ for females

$=0.004 *[$ initial lung weight $(g)+166 \times G M(t)]$ for males

where

$$
G F(t)=1-\exp (-0.0169 * t 0.822)
$$

and

$$
G m(t)=1-\exp (-0.0133 * t 0.938)
$$

The function $W(t)$ was estimated by assuming that the lung weight was a fraction (males $0.5 \%$, females $0.4 \%$ ) of the body weight of the control rats in the study (Lundgren, 1980).

Lung retention and dose accumlation patterns in lung are plotted in Figures 3.1 and 3.2. Because most of the animals in the study were below the median lethal dose range, only the dose accumulation patterns for these animals are shown. One $\mathrm{MBq}$ of $90 \mathrm{Sr} / \mathrm{g}$ lung initial lung burden equalled 210 Gy $(27,000$ rad) at 365 days after inhalation or 320 Gy $(32,000$ rad $)$ at 900 days. 


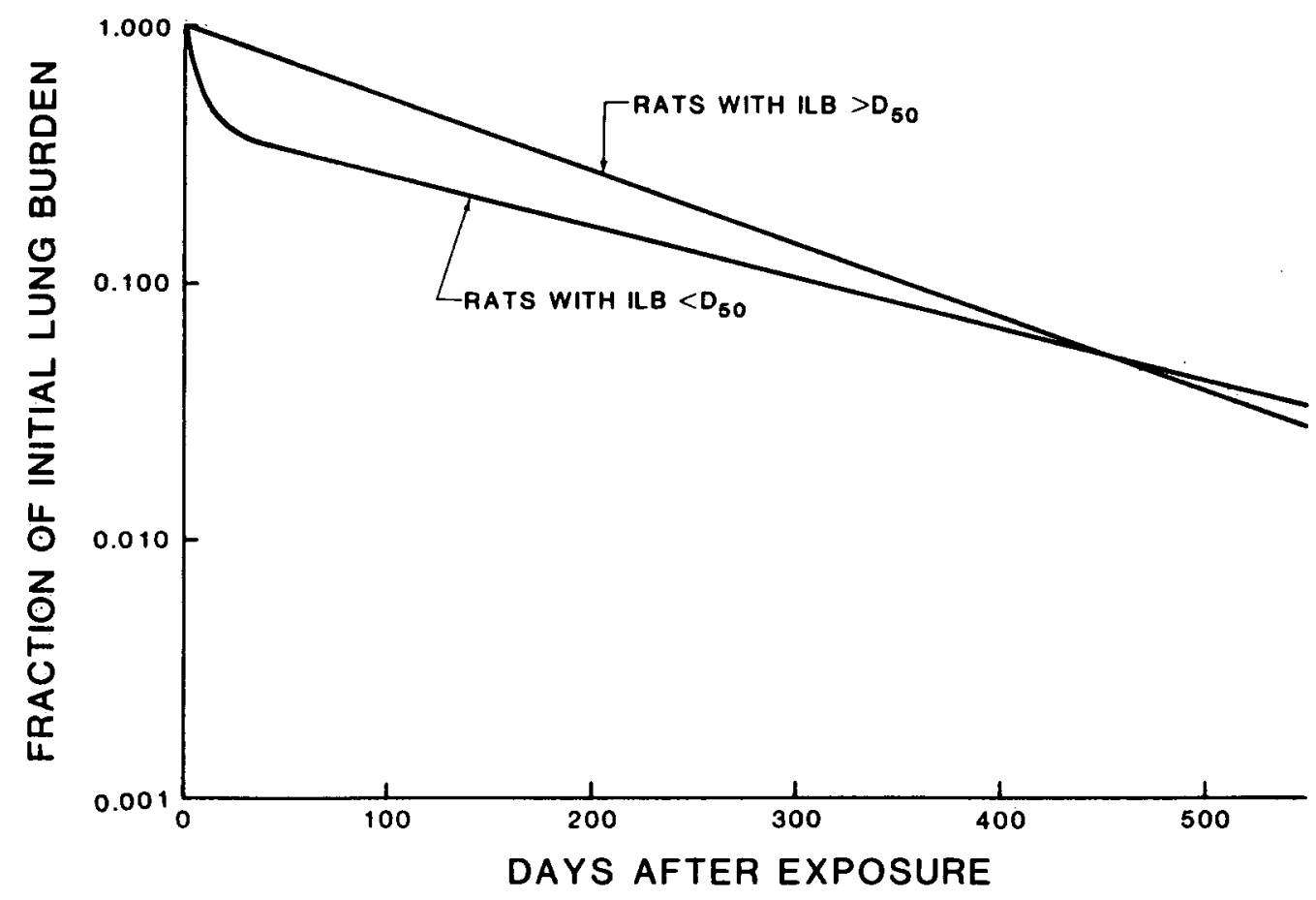

3.1 Pulmonary retention pattern for inhaled $90 \mathrm{Sr}$ in fused aluminosilicate particles. $0_{50}=1170$ $\mathrm{kBq} / \mathrm{g}$ lung or a 900 day dose of $370 \mathrm{~Gy}(37,000 \mathrm{rad})$.

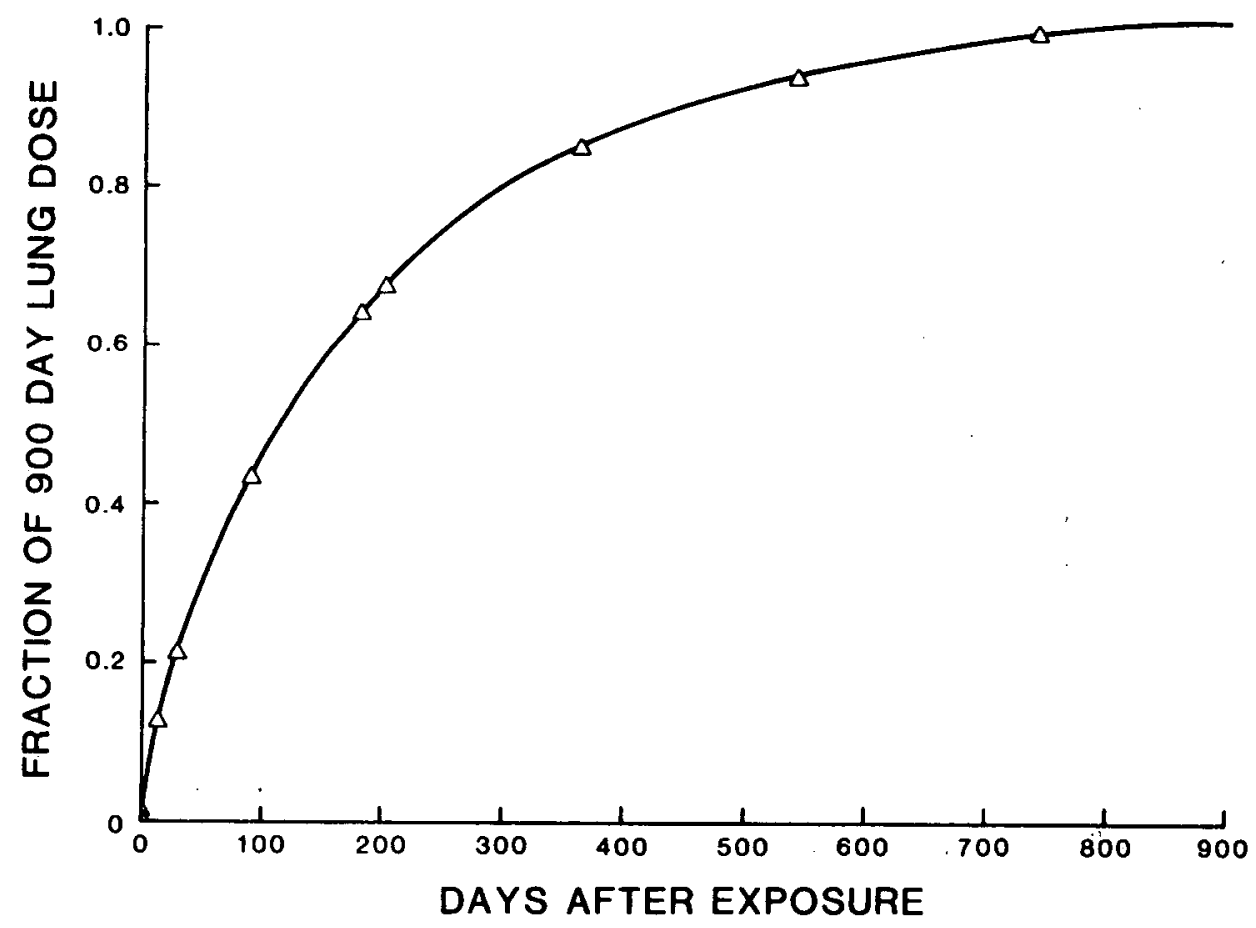

3.2 Calculated pulmonary dose accumulation pattern after inhalation of 90 sr in fused aluminosilicate particles. 


\subsubsection{Rats Exposed to $90 Y$}

The $90 \mathrm{Y}$ activity in lung was assumed to be reduced mainly by physical decay of $90 \mathrm{Y}$ (half-life of 64.1 hours). The $90 \mathrm{Sr}$ contaminant was assumed to have the same retention in lung as $90 \mathrm{Sr}$ administered singly. This led to the retention function for $90 \mathrm{Y}$. with $2.3 \%$. 90 Sr contamination of

retention $90 \mathrm{Y}+2.3 \% 90 \mathrm{Sr}=0.977 \exp (-0.26 \mathrm{~T})+0.0066 \exp (-0.15 \mathrm{~T})+0.0164 \exp (-0.005 \mathrm{~T})$,

where $\mathrm{T}$ represents days after exposure.

To obtain cumulative rads to the lung, a computer program that accounts for growth of the animals was used. Calculated cumulative doses to the 1 ung at 30 and 900 days, and at: death are reported in the Appendix.

L.ung retention and dose accumulation patterns in lung are plotted in Figures 3.3 and 3.4. One $\mathrm{MBq}$ of $90 \mathrm{Y} / \mathrm{g}$ lung initial lung burden equalled 19 Gy (1900 rad) at 365 days after exposure or 20 Gy (2000 rad) at 900 days.

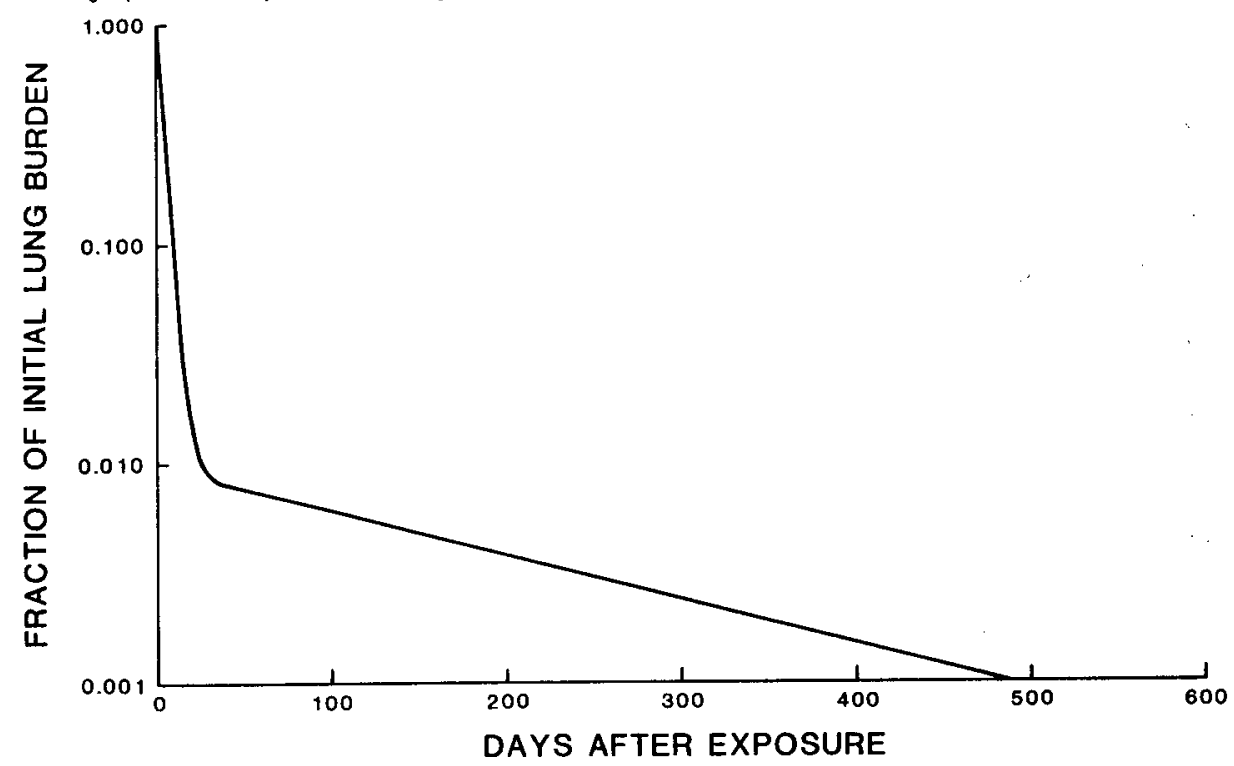

3.3 Pulmonary retention pattern for inhaled $90 y$ mixed with $2.3 \% 90$ sr in fused aluminosilicate particles.

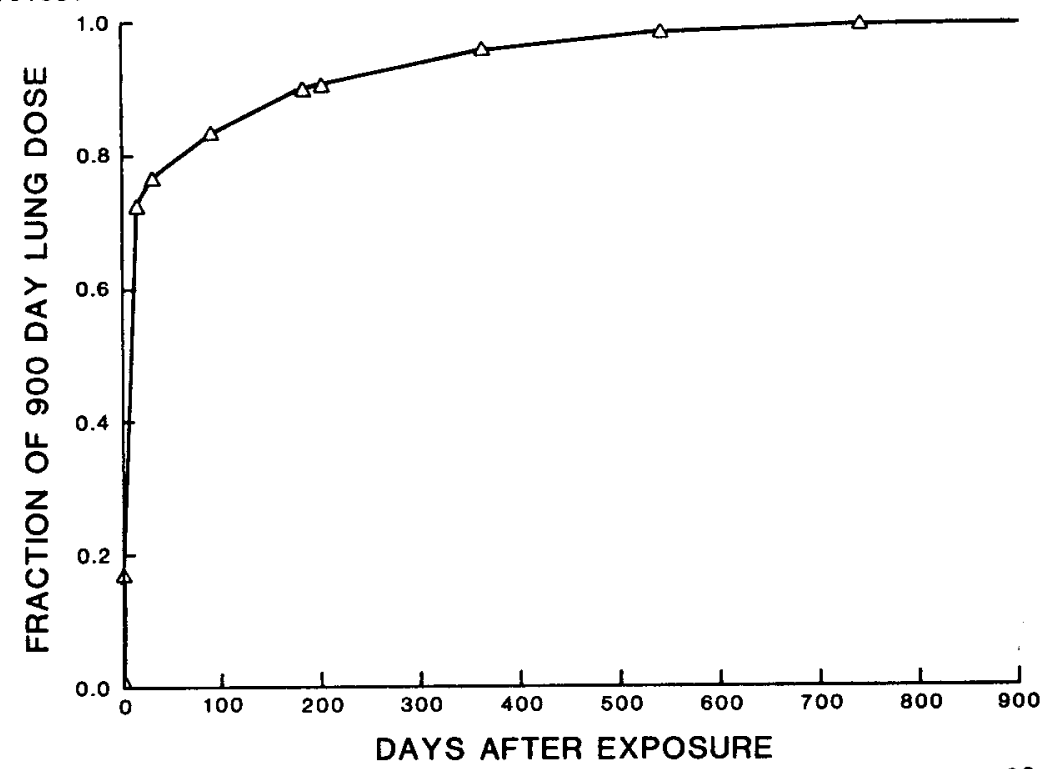

3.4 Calculated pulmonary dose accumulation pattern after inhalation of $90 \mathrm{Y}$ mixed with' $2.3 \% 90 \mathrm{Sr}$ in fused aluminosilicate particles. 


\subsubsection{Rats Exposed to $90 Y+90 S r$ \\ The $90 \mathrm{Sr}$ in the mixture was assumed to have the same retention in lung as $90_{S r}$}

administered by itself. The $90 \mathrm{Y}$ activity was assumed to be eliminated mainly by physical decay (half-life of 64.7 hours). This leads to a retention function for the mixture having $75 \%$ of the initial activity due to $90 \mathrm{Y}$ and $25 \%$ due to $90 \mathrm{Sr}$ given by

Retention $90 \mathrm{Y}+25 \% 90 \mathrm{Sr}=0.75 \exp (-0.26 \mathrm{~T})+0.071 \exp (-0.15 \mathrm{~T})+0.179 \exp (-0.005 \mathrm{~T})$,

where $T$ represents days after exposure.

To obtain cumulative doses to the lung, a computer program was used that accounts for growth of the animals. Calculated cumulative doses to the lung at 30 and 900 days, and at death are reported in the Appendix.

Lung retention and dose accumulation patterns in lung are plotted in Figures 3.5 and 3.6. One MBq of $90 y+90 \mathrm{Sr} / \mathrm{g}$ lung initial lung burden equalled 71 Gy ( 7100 rad) at 365 days after inhalation or 80 Gy (8000 rad) at 900 days.

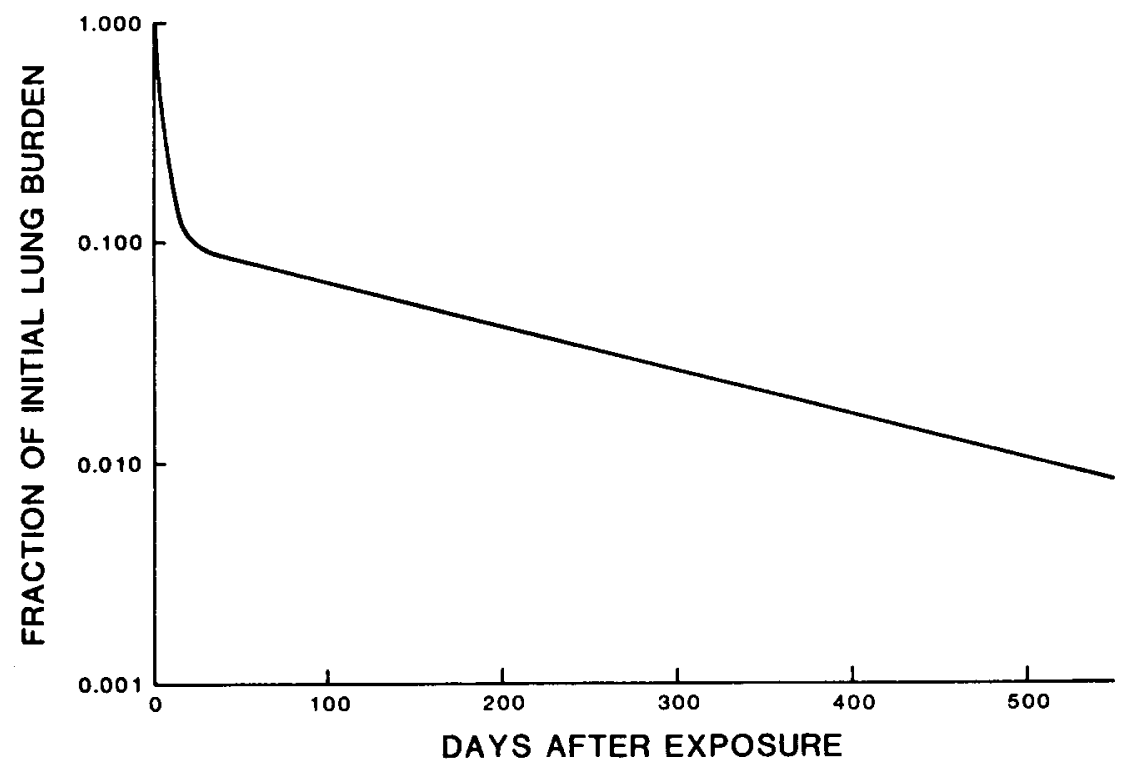

3.5 Pulmonary retention pattern for inhaled $90 \mathrm{Y}$ mixed with $25 \%{ }^{90} \mathrm{Sr}$ in fused aluminosilicate particles.

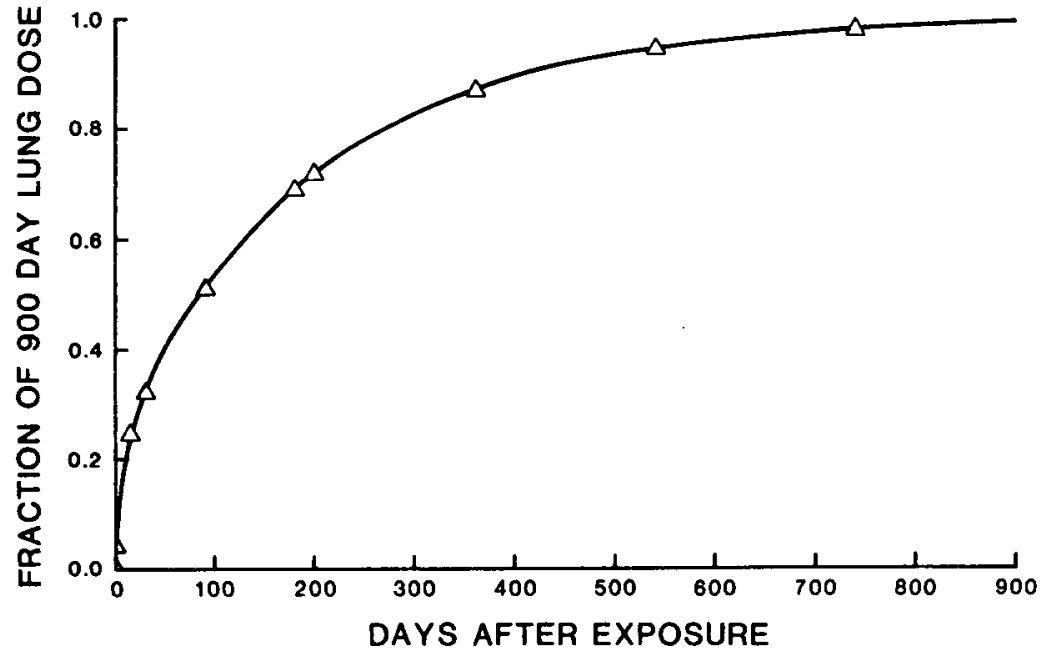

3.6 Calculated pulmonary dose accumulation pattern after inhalation of $90_{Y}$ mixed with $25 \% 90 \mathrm{Sr}$ in fused aluminosilicate particles. 


\subsubsection{Survival Distribution}

The survival times for each rat were recorded to 1.5 years after inhalation exposure and are recorded in the Appendix. The survival times for those dying of radiation pneumonitis and pulmonary fibrosis are graphed in Figure 3.7 for $90 \mathrm{Sr}$, Figure 3.8 for $90 \mathrm{Y}+2.3 \% 90 \mathrm{Sr}$ and Figure 3.9 for $90 Y+25 \% 90 S r$ : "The mean survival times and fractions of animals that died between 365 and 540 days after exposure are shown in Table 3.5. The mean survival time was much longer in rats receiving the protracted irradiation from the ${ }^{90} \mathrm{Sr}$ deposited in the lung. The survival times were not normaliy distributed, as shown in figure 3.10. There was a bimodal distribution of deaths with one peak occurring between 60 and 180 days after exposure and a second, but smaller, peak, between 380 and 500 days after exposure.

Examination of the rats that died revealed several causes of death just as in the study with rats exposed to $147 \mathrm{Pm}$ in fused aluminosilicate particles. The major findings at death are noted for each rat in the Appendix. The most prevalent cause of death was radiation pneumonitis and pulmonary fibrosis. It was characterized by increased numbers of vacuolated alveolar macrophages and occasional neutrophils, alveolar necrosis, alveolar hemosiderin, vasculitis and fine alveolar septal fibrosis. In rats that died at earlier times, the inflammatory component, radiation pneumonitis, was most prominent. At later times, fibrosis was more prominent. In a few cases, severe vasculitis with pulmonary thrombosis was a key feature.

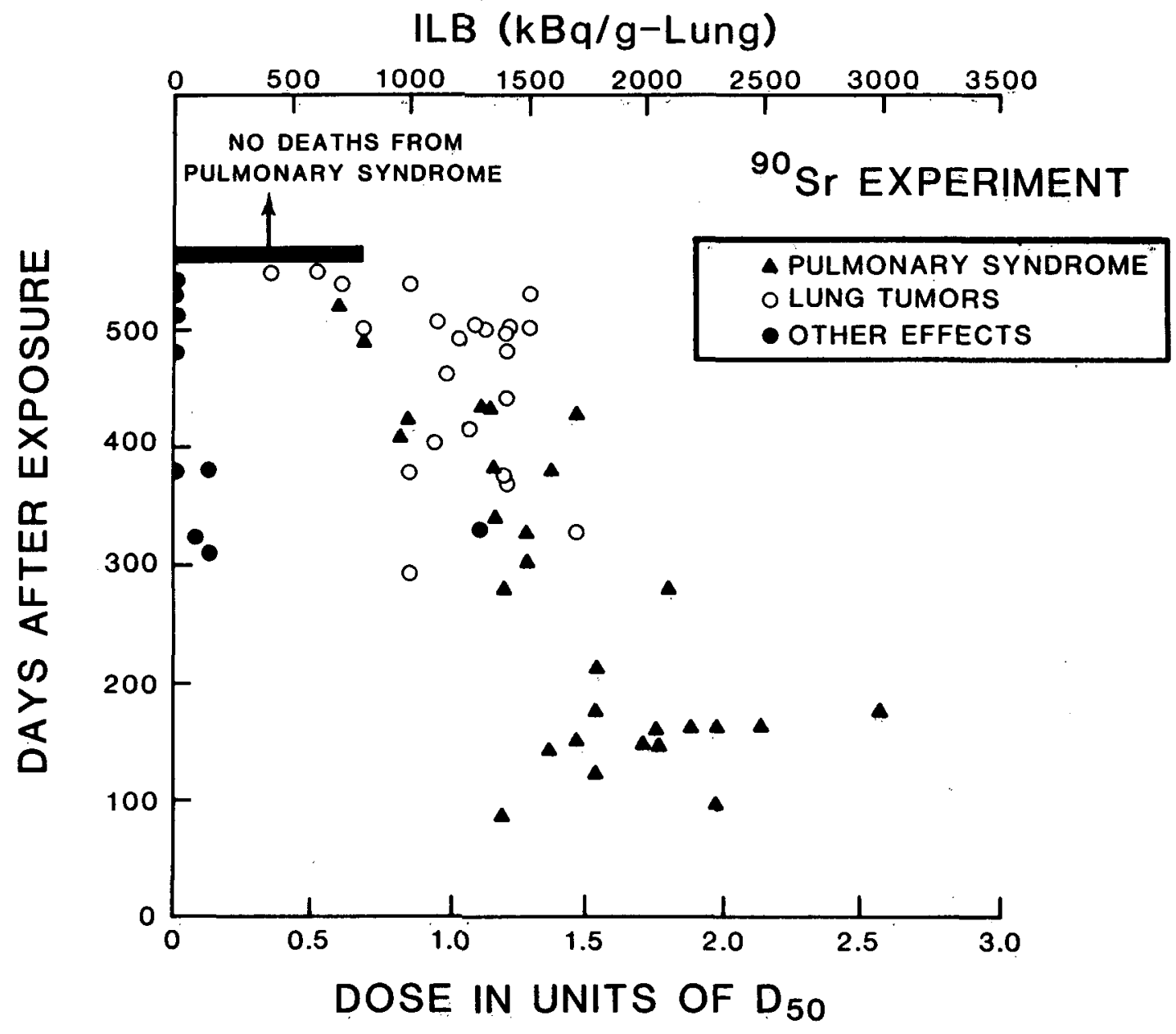

3.7 Time to death from radiation pneumonitis and its relation to initial lung burden after inhalation of $90 \mathrm{Sr}$ in fused aluminosilicate particles. A dose of 1 in units of the 050 equals a $50 \%$ lethality dose for death from radiation pneumonitis and corresponds to 1200 $\mathrm{kBq} / \mathrm{g}$ lung or a 900 day dose of 370 Gy $(37,000$ rad). Includes animals in mortality, hematology and pulmonary function groups. 


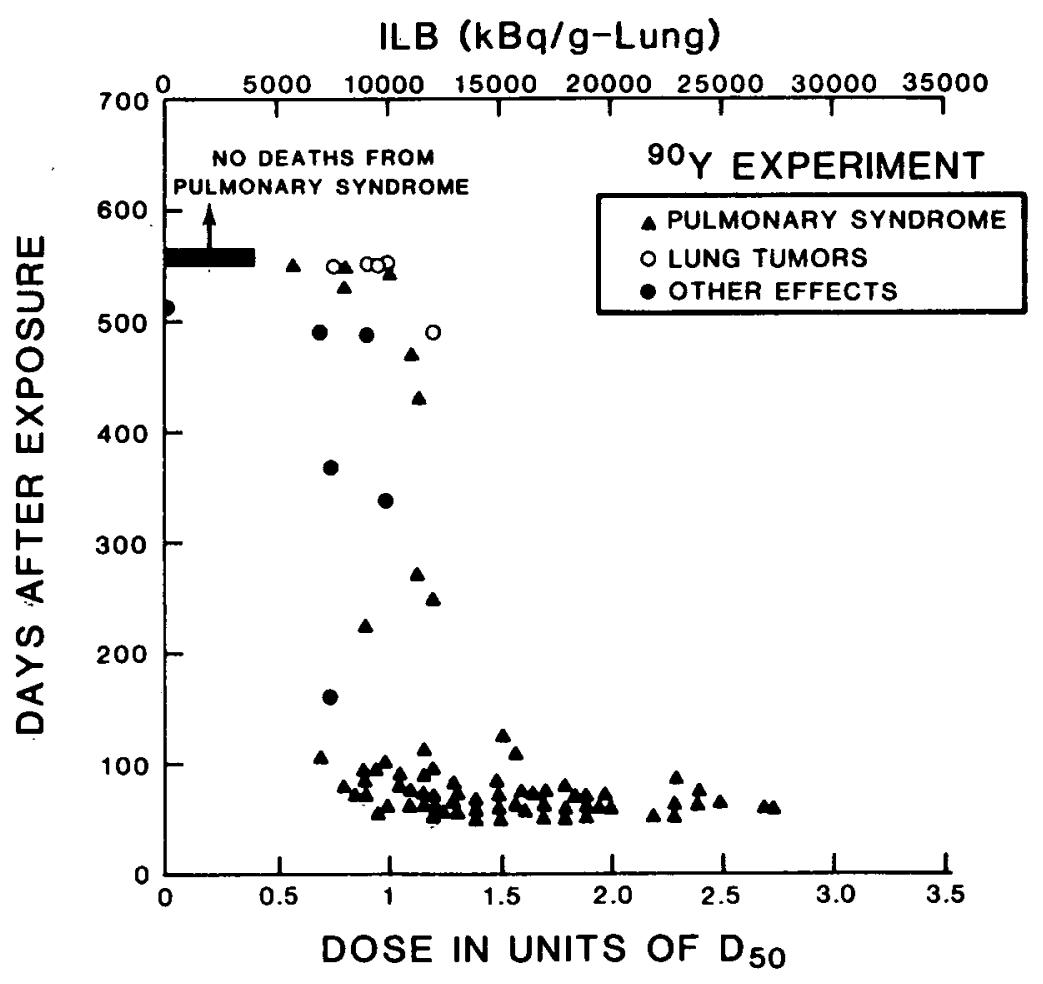

3.8 Time to death from radiation pneumonitis and its relation to dose after inhalation of $90 Y$ mixed with $2.3 \% 90 \mathrm{Sr}$ in fused aluminosilicate particles. A dose of 1 in units of the $0_{50}$ equals a $50 \%$ lethality dose for death from radiation pneumonitis and corresponds to 10,000 $\mathrm{kBq} / \mathrm{g}$ lung or a 900 day dose of $200 \mathrm{~Gy}(20,000 \mathrm{rad})$. Includes animals in mortality, hematology and pulmonary function groups.

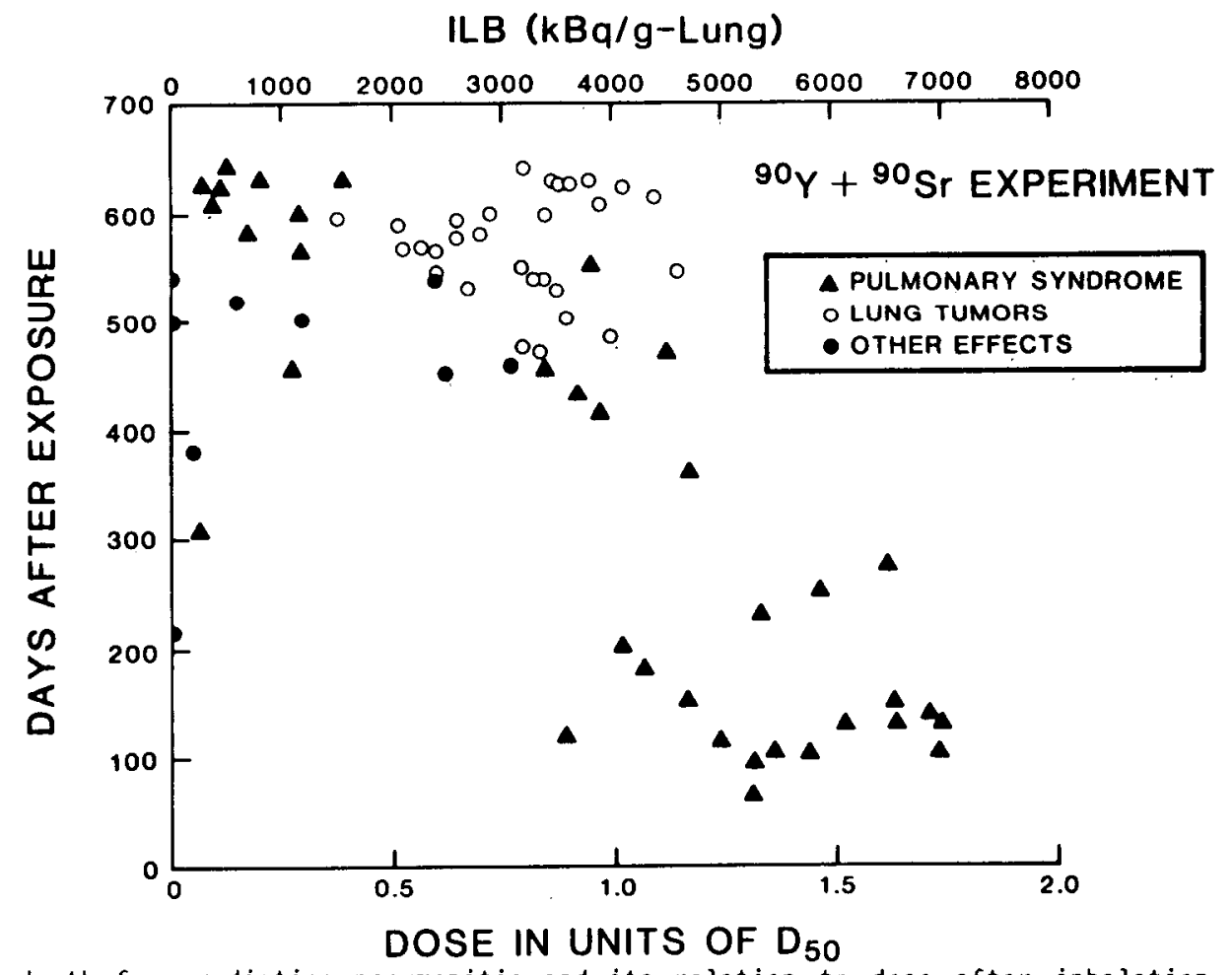

3.9 Time to death from radiation pneumonitis and its relation to dose after inhalation of $90 \mathrm{Y}$ mixed with $25 \% 90 \mathrm{Sr}$ in fused aluminosilicate prticles. A dose of 1 in units of the $0_{50}$ equals a $50 \%$ lethality dose for death from radiation pneumonitis and corresponds to 4000 $\mathrm{kBq} / \mathrm{g}$ lung or a 900 day dose of 330 Gy $(33,000 \mathrm{rad})$. Includes animals in mortality, hematology and pulmonary function groups. 
Table 3.5

Comparison of Survival Times in Rats Exposed to

Beta-Emitting Radionuclides with Differing Half-times in the Lung

\begin{tabular}{|c|c|c|c|c|c|c|c|c|}
\hline \multirow{5}{*}{$-\frac{\text { Radionuclide }}{90 \mathrm{Sr}}$} & \multicolumn{6}{|c|}{ Clearance Times } & \multirow{4}{*}{$\begin{array}{c}\text { Mean } \\
\text { Survival } \\
\text { Time } \\
\text { (days) }\end{array}$} & \multirow{4}{*}{$\begin{array}{r}\text { Died Between } \\
365-540 \text { dpe } \\
(\%)\end{array}$} \\
\hline & \multicolumn{2}{|c|}{ Component 1} & \multicolumn{2}{|c|}{ Component 2} & \multicolumn{2}{|c|}{ Component 3} & & \\
\hline & $A_{1}$ & $\mathrm{t}_{1 / 2}$ & $A_{2}$ & $\mathrm{t}_{1 / 2}$ & $A_{3}$ & $t_{1 / 2}$ & & \\
\hline & $(\%)$ & (days) & $(\%)$ & (days). & $(\%)$ & (days) & & \\
\hline & - & - - & 58 & 4.6 & 18 & 150 & 283 & 37 \\
\hline $90 Y+25 \% 90 S r$ & 75 & 2.7 & 7 & 4.6 & 18 & 140 & 223 & 20 \\
\hline $90 y:+2.390 \mathrm{Sr}$ & 97 & 2.7 & 1 & 4.6 & 2 & 140 & 97 & 5 \\
\hline
\end{tabular}

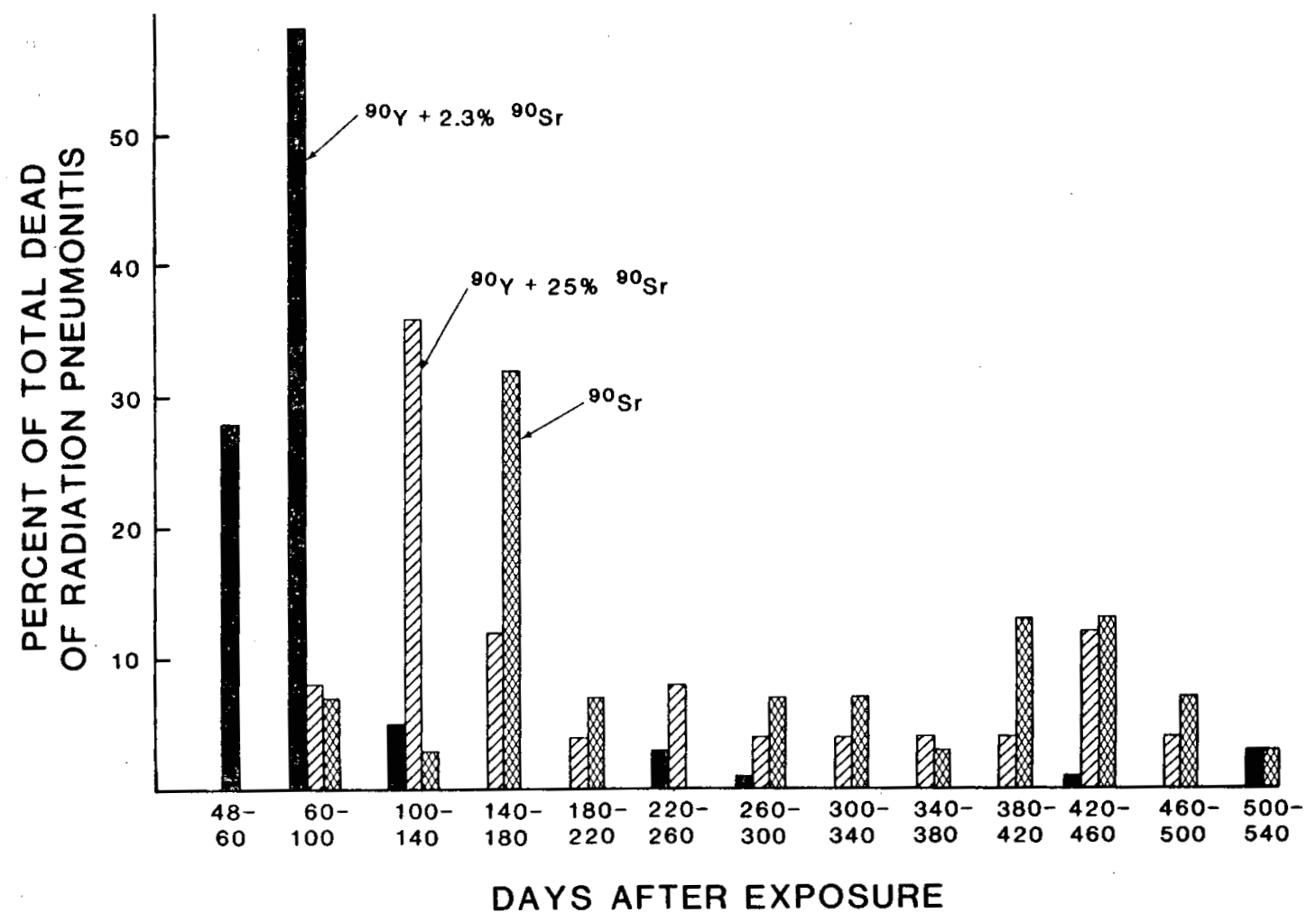

3.10 Distribution of survival of times for rats dying of radiation pneumonitis and pulmonary fibrosis after inhalation of either $90 \mathrm{Sr}, 90 Y+2.3 \% 90 \mathrm{Sr}$ or $90 Y+25 \% 90 \mathrm{Sr}$ in fused aluminosilicate particles. 


\subsubsection{Body Weight Data}

A constant weight-gain model was used to analyze the body weight data for rats exposed by inhalation to each of the three combinations of $90 \mathrm{Sr}$ and $90 \mathrm{y}$. In addition to control rats, three dose groups were formed (low, medium, and high) for each study containing approximately the same number of individuals. Males and females were analyzed separately.

Body weight gain after exposure for males and females are plotted in figures 3.11 and 3.12 for $90 \mathrm{Sr}$. Figures 3.13 and 3.14 for $90 Y+2.3 \% 90 \mathrm{Sr}$ and Figures 3.15 and 3.16 for $90 \mathrm{Y}+25 \% 90 \mathrm{Sr}$. There was a decreased weight gain in all those groups of rats that had a lethal dose (a D50 unit dose of 1 or greater) Table 3.6. Another finding was a distinct flattening, or in the case of the $90 Y+2.3 \% 90 S r$ study, an actual weight loss in the high dose group between 50 and 150 days after inhalation exposure. These decreases in weight gain corresponded with the times that the highest fraction of rats died of radiation pneumonitis (see figure 3.10). Thus, reduction in weight gain and deaths from radiation pneumonitis were correlated as would be expected. There was not, however, a weight gain reduction in those groups where a majority of the rats survived.

\subsubsection{Hematological Data}

Hematological measurements were recorded just before exposure (baseline) and at $7,14,30$, $60,90,180$, and 360 days after exposure for 20 males and 20 females assigned to the hematology groups in each of the studies. For the analysis of the data, three dose groups (low, medium and high) containing approximately the same number of rats were formed for each of the three studies. Each of the parameters measured (red and white blood cell concentration, white blood cell differential count and hematocrit), in each dose group were compared with the respective control groups sampled at the same time.

The only values that were altered were the total lymphocyte counts as shown in figure 3.17 for $90 \mathrm{Sr}$, Figure 3.18 for $90 \mathrm{Y}+2.3 \% 90 \mathrm{Sr}$ and Figure 3.19 for $90 \mathrm{Y}+25 \% 90 \mathrm{Sr}$.

3.3.5 Pulmonary Function Data

Pulmonary function was measured before exposure and at $2,3,6,9,12$ and 18 months after inhalation exposure in a designated group of 20 control rats and of 60 rats exposed to $90 \mathrm{Sr}$ in fused aluminosilicate particles. Pulmonary function was also measured in 12 control rats and 36 rats surviving 18 months after inhalation exposure to $90 \mathrm{Y}+2.3 \% 90 \mathrm{Sr}$ in fused aluminosilicate particles. The pulmonary function data for each of these rats are given in the Appendix. As shown in Figures $3.20,3.27$ and 3.22 , for control males, the vital capacity, co diffusing capacity, and quasistatic compliance are all strongly age dependent. However, as shown in Figures 3.23 and 3.24, the age dependence of the c0 diffusing capacity can be eliminated by normalizing to the alveolar volume, and the age dependence of the vital capacity can be eliminated by dividing by the total lung capacity. Similar results were obtained for females, although the vital capacity, co diffusing capacity, and quasistatic compliance were clearly different for males and females. The normalizations also tended to reduce the sex differences. These results demonstrate that both age and sex-related differences in these parameters are largely due to changes or differences in lung size.

To construct dose-effect relationships, a second normalization was carried out in which results were expressed as a percentage of control values taken at the same time after exposure as for test rats. With this normalization, data for males and females could then be combined. values outside the range of $\pm 20 \%$ of normal values are typically considered abnormal in human studies. In these studies of rats, values outside the range of $\pm 20 \%$ of the mean control value were considered abnormal.

For the purposes of analysis of the rats exposed to $90 \mathrm{Sr}$, two groups were considered: (1) those with sublethal doses and lower dose rates that survived to 1.5 years after exposure and 


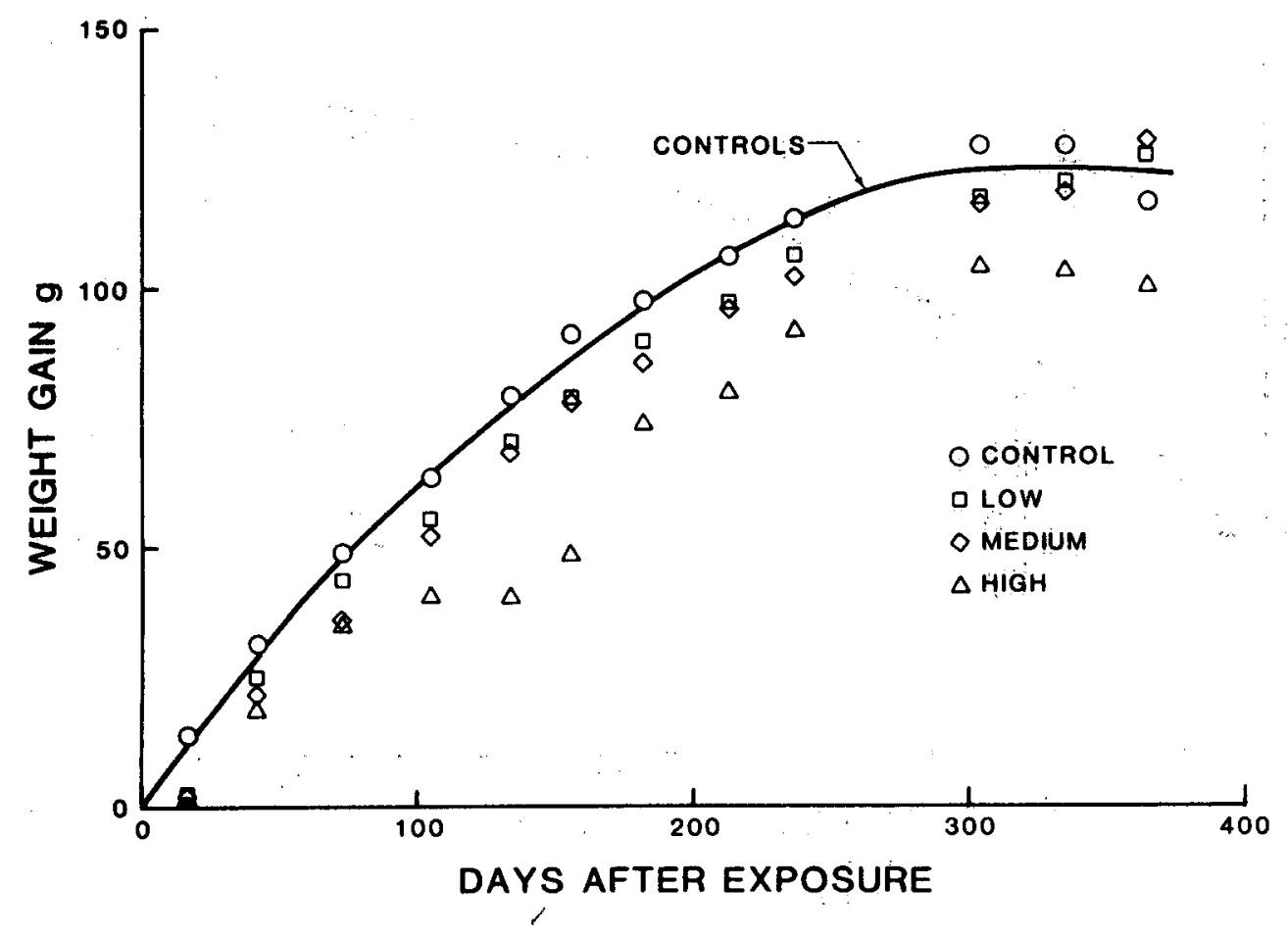

3.11 Body weight gain for male rats after inhalation exposure to ${ }^{90} \mathrm{Sr}$ in fused aluminosilicate particles. Four dose groups are shown: controls, low, medium and high with average doses in units of the $D_{50}$ of $0,0.0,0.1,0.6$ and 1.4 , respectively.

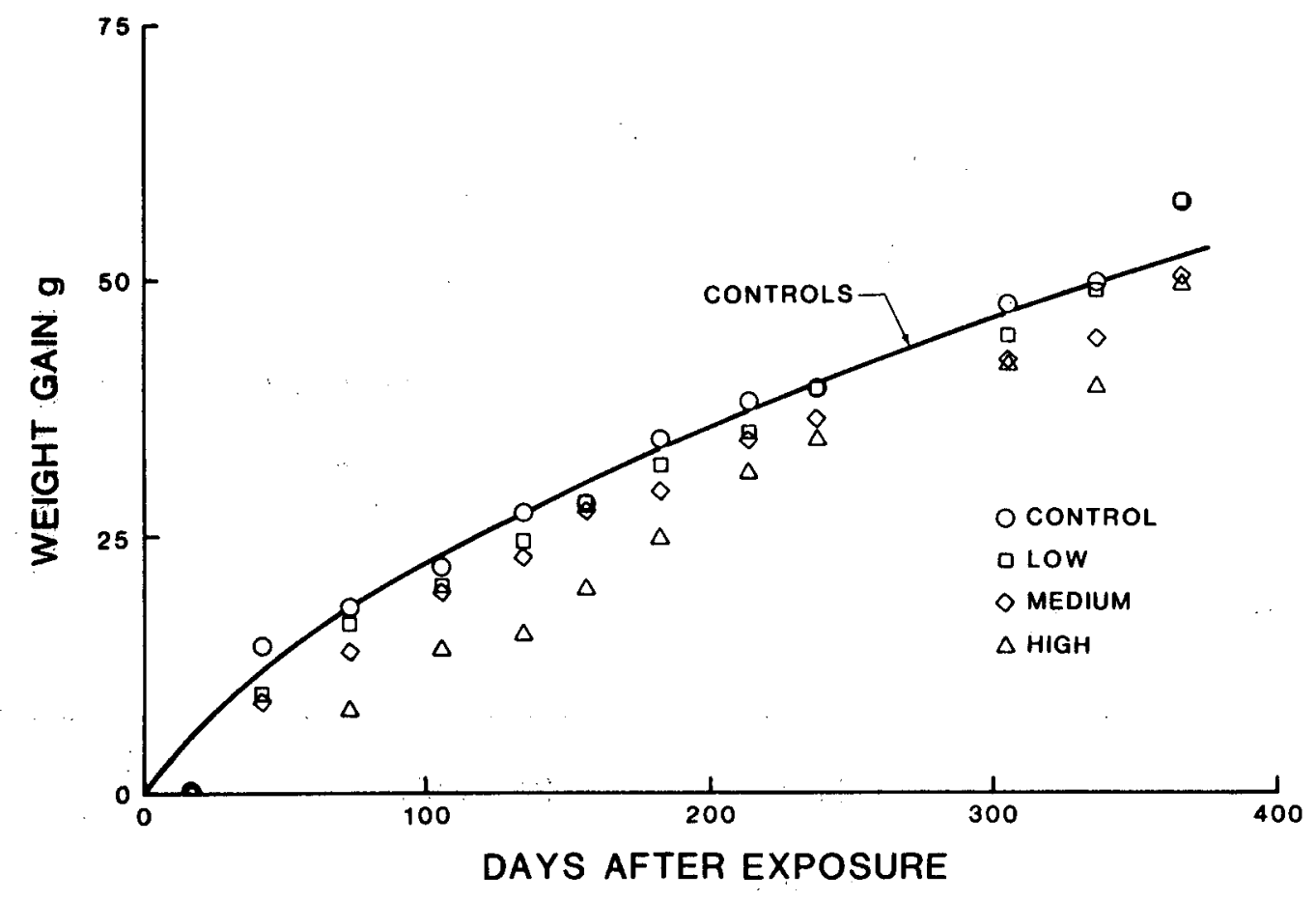

3.12 Body weight gain for female rats after inhalation exposure to $90_{S r}$ in fused aluminosilicate particles. Four dose groups are shown: controls, low, medium and high with average doses in units of the $D_{50}$ of $0,0.0,0.2,0.4$ and 1.2 , respectively. 


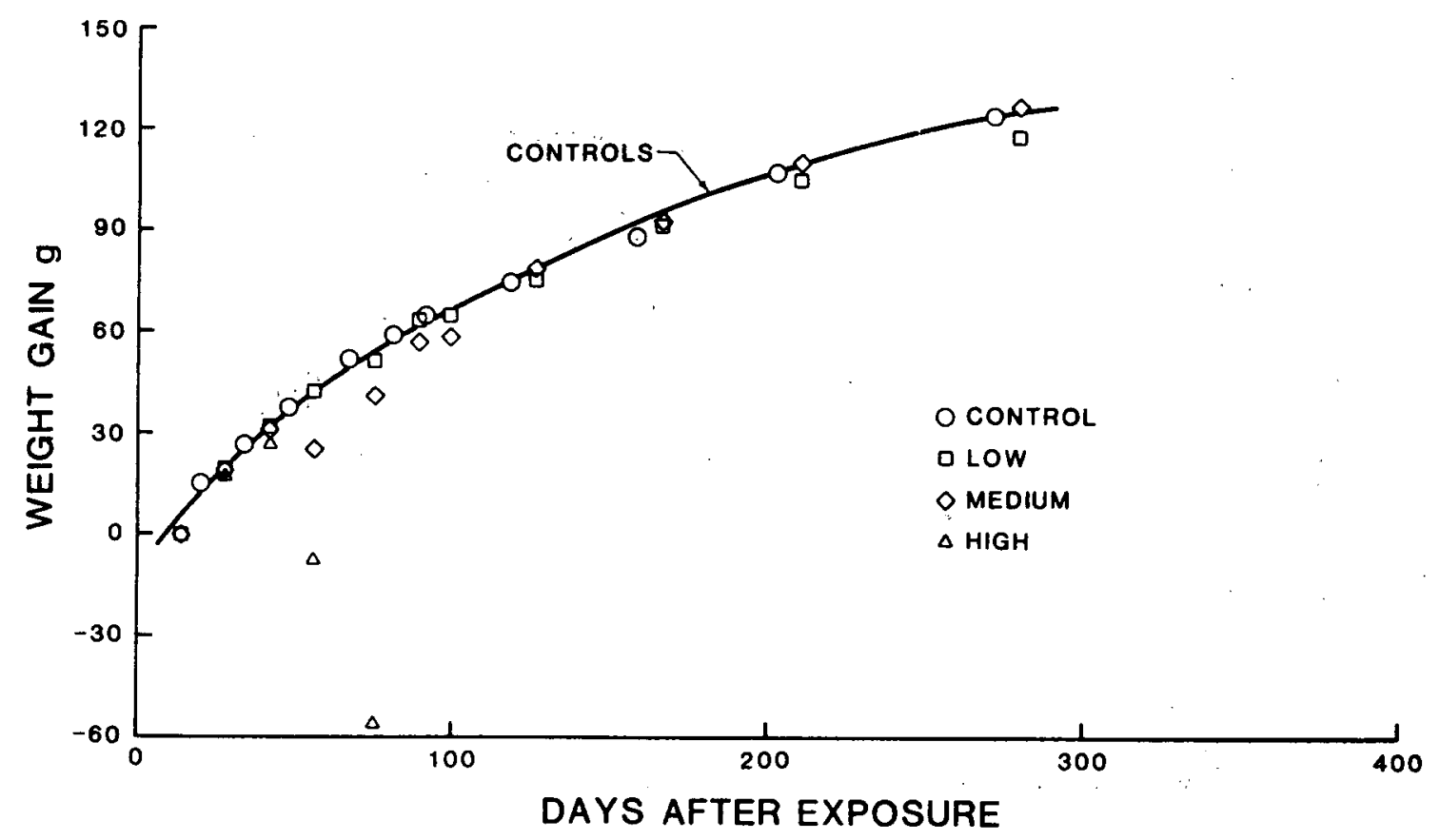

3.13 Body weight gain for male rats after inhalation exposure to $90 \mathrm{Y}+2.3 \% 90 \mathrm{Sr}$ in fused aluminosilicate particles. Low, medium and high groups have average doses in units of the $D_{50}$ of $0.7,1.3$ and 2.0 , respectively.

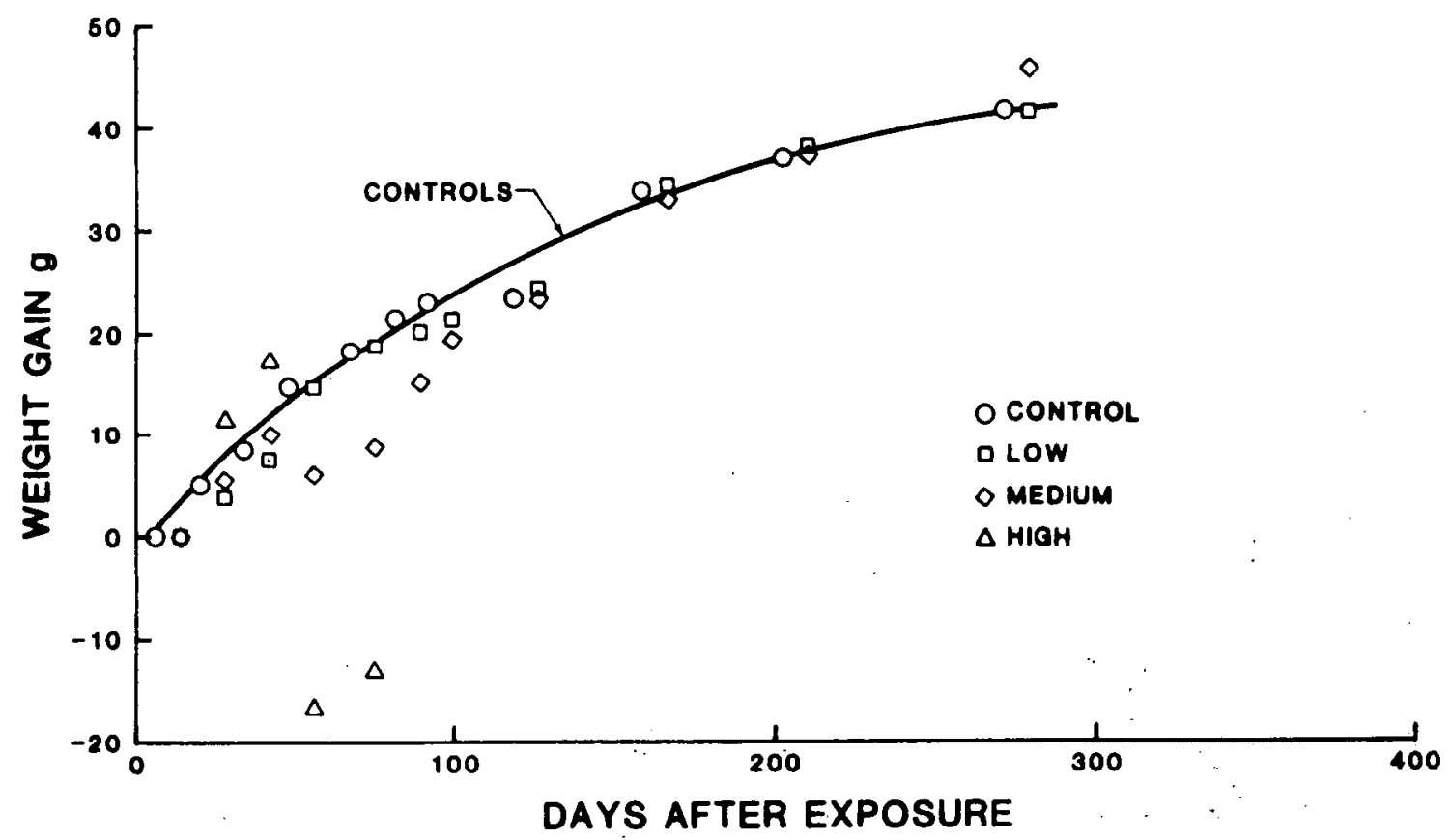

3.14 Body weight gain for female rats after inhalation exposure to $90 \mathrm{Y}$ and $2.3 \% 90 \mathrm{Sr}$ is fused aluminosilicate particles. Low, medium and high groups have average doses in units of the $D_{50}$ of $0.5,0.8$ an 1.4 , respectively. 


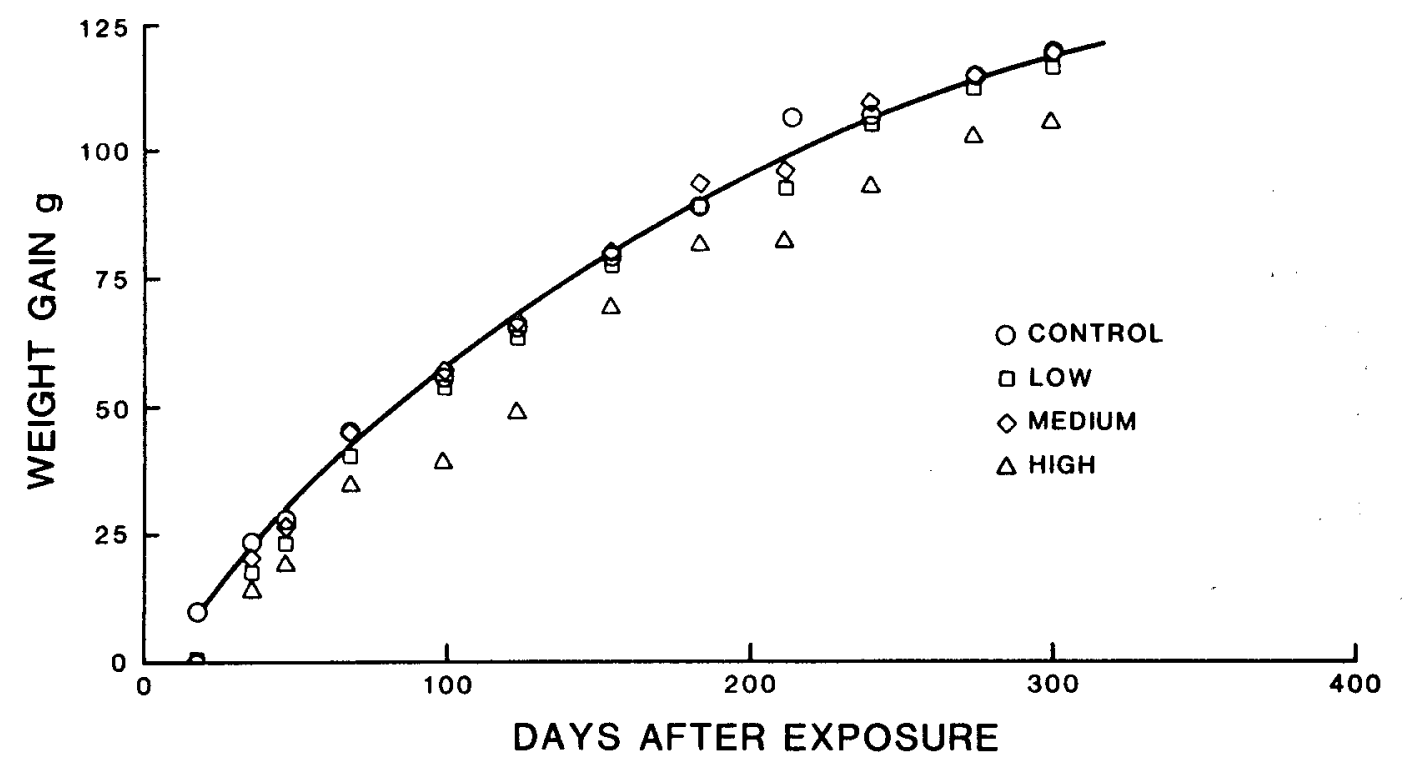

3.15 Body weight gain for male rats after inhalation exposure to $90 \mathrm{Y}+25 \% 90 \mathrm{Sr}$ in fused aluminosilicate particles. Low, medium and high groups have average doses in units of the $D_{50}$ of $0.7,0.3$ and 0.9 , respectively.

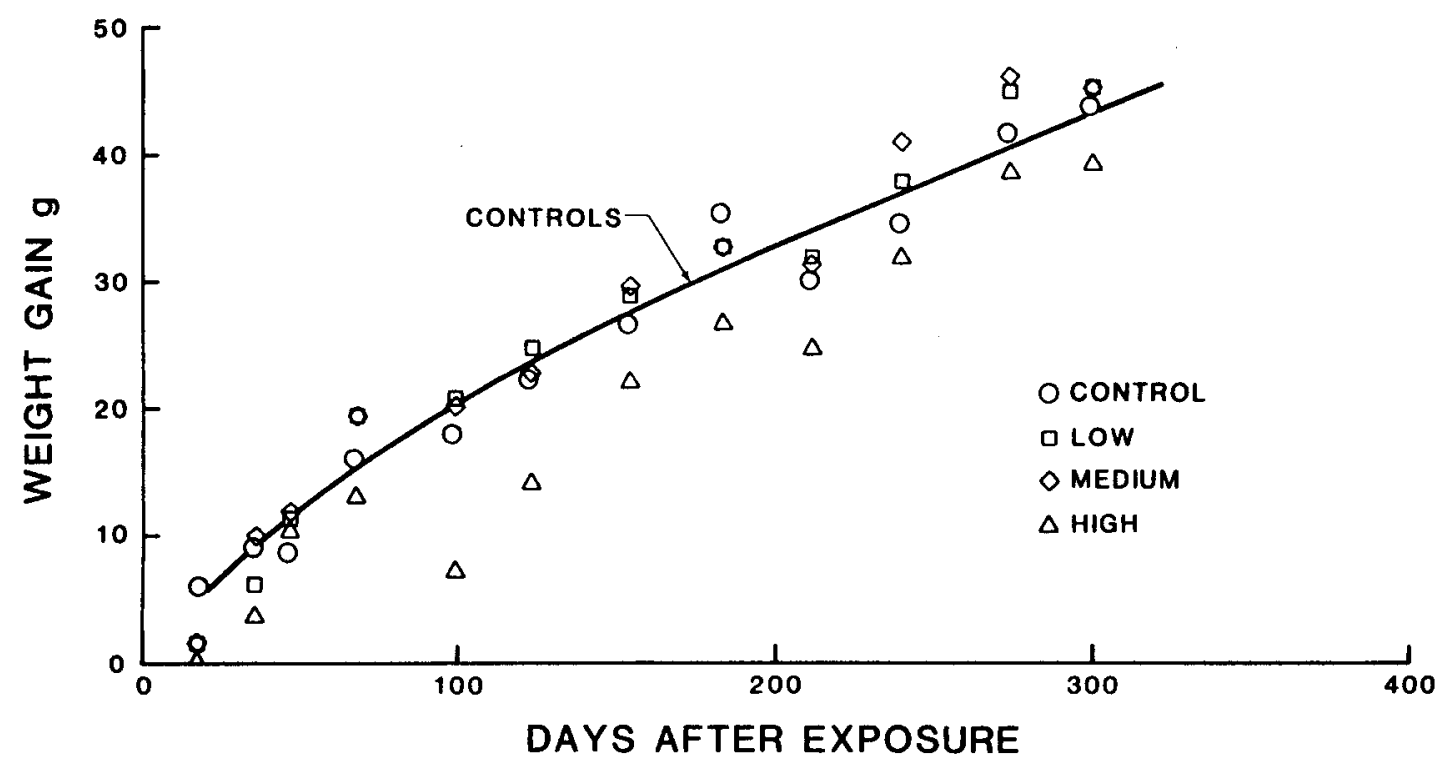

3.16 Body weight gain for female rats after inhalation exposure to $90 \mathrm{Y}+25 \% 90 \mathrm{Sr}$ in fused aluminosilicate particles. Low, medium and high groups have average doses in units of the $0_{50}$ of $0.1,0.3$ and 1.1 , respective $1 y$. 
Table 3.6

Comparison of Effect of Inhaled Beta Emitters on Body Weight Gain

\begin{tabular}{|c|c|c|c|c|c|c|}
\hline \multirow{3}{*}{$\begin{array}{c}\text { Radionuclide } \\
\text { Exposure }\end{array}$} & \multicolumn{6}{|c|}{ Dose Groups } \\
\hline & \multicolumn{2}{|c|}{ High } & \multicolumn{2}{|c|}{ Medium } & \multicolumn{2}{|c|}{ Low } \\
\hline & Males & Females & Males & Females & Males & Females \\
\hline \multicolumn{7}{|l|}{$90_{S r}$} \\
\hline $\begin{array}{l}\text { Average Dose* } \\
\text { in Group }\end{array}$ & 1.4 & 1.2 & 0.6 & 0.4 & 0.1 & 0.2 \\
\hline Effect on weight & - & - & \pm & \pm & \pm & \pm \\
\hline \multicolumn{7}{|l|}{${ }^{90} \mathrm{sr}+2.3 \%{ }^{90} \mathrm{sr}$} \\
\hline $\begin{array}{l}\text { Average Dose* } \\
\text { in Group }\end{array}$ & 2.0 & 1.4 & 1.3 & 0.8 & 0.7 & 0.5 \\
\hline Effect on weight & - & - & \pm & - & 0 & 0 \\
\hline \multicolumn{7}{|l|}{$90 \gamma+25 \% 90 S r$} \\
\hline $\begin{array}{l}\text { Average Dose* } \\
\text { in Group }\end{array}$ & 0.9 & 1.1 & 0.3 & 0.3 & 0.1 & 0.1 \\
\hline Effect on Weight & \pm & - & 0 & 0 & 0 & 0 \\
\hline
\end{tabular}

* = Doses in units of the $0_{50}$. A dose of 1 represents a median lethal dose.

- = Decrease in body weight gain.

$\pm=$ Marginal decrease in body weight gain.

$\mathbf{0}=$ No effect on body weight gain.

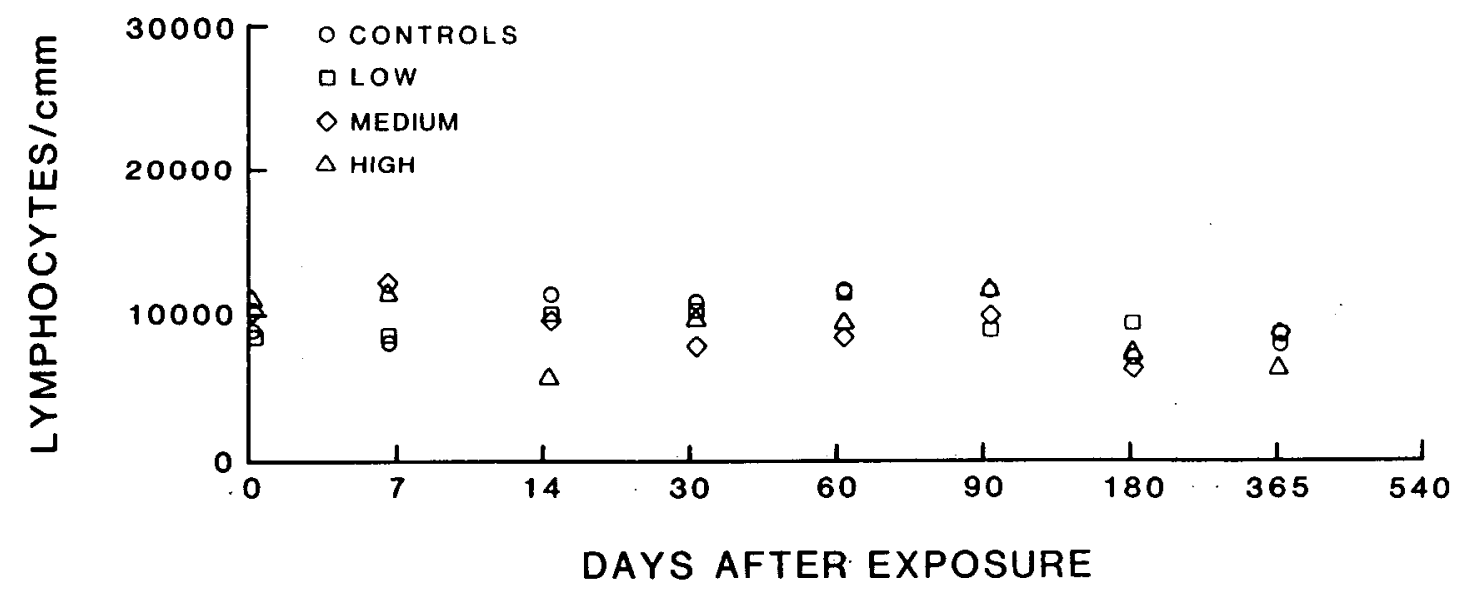

3.17 Blood lymphocyte concentration after inhalation exposure to $90 \mathrm{Sr}$ in fused aluminosilicate particles. Low, medium and high groups have average doses in units of the $0_{50}$ of $0.04-0.2$, $0.2-1.0$ and $1.7-2.4$, respectively. 


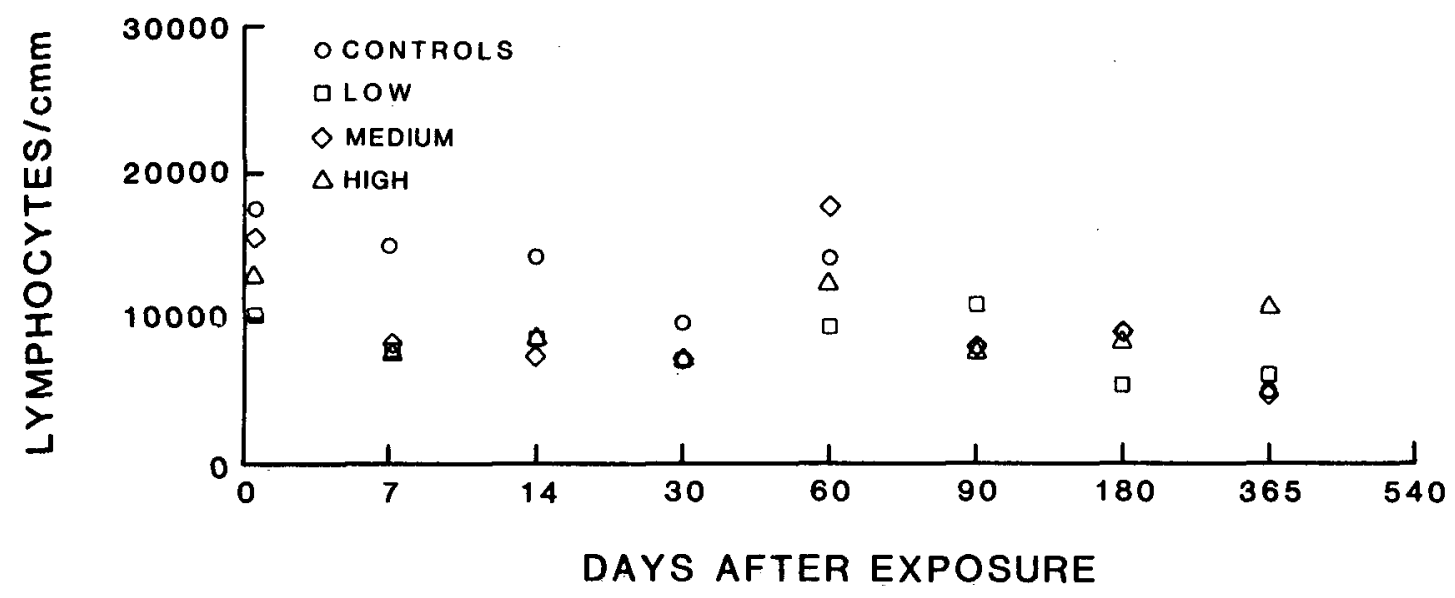

3.18 Blood lymphocyte concentration after inhalation exposure to $90 \mathrm{Y}+2.3 \% 90 \mathrm{Sr}$ in fused aluminosilicate particles. Low, medium and high groups have average doses in units of $D_{50}$ of $0.2-0.8,0.8-1.2$ and $1.2-2.2$, respectively.

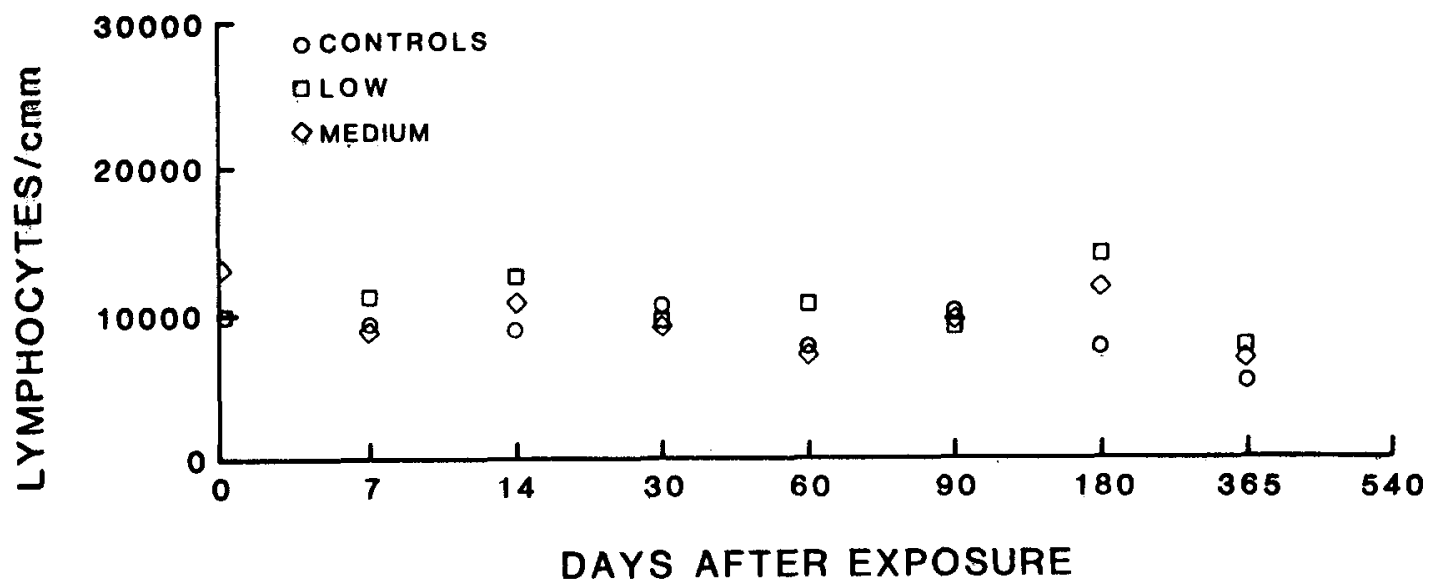

3.1987 lood lymphocyte concentration after inhalation exposure to $90 \mathrm{Y}+25 \% 90 \mathrm{Sr}$ in fused aluminosilicate particles. Low and medium groups have average doses in units of $0_{50}$ of $0.04-0.2$ and $0.2-0.3$, respectively. 


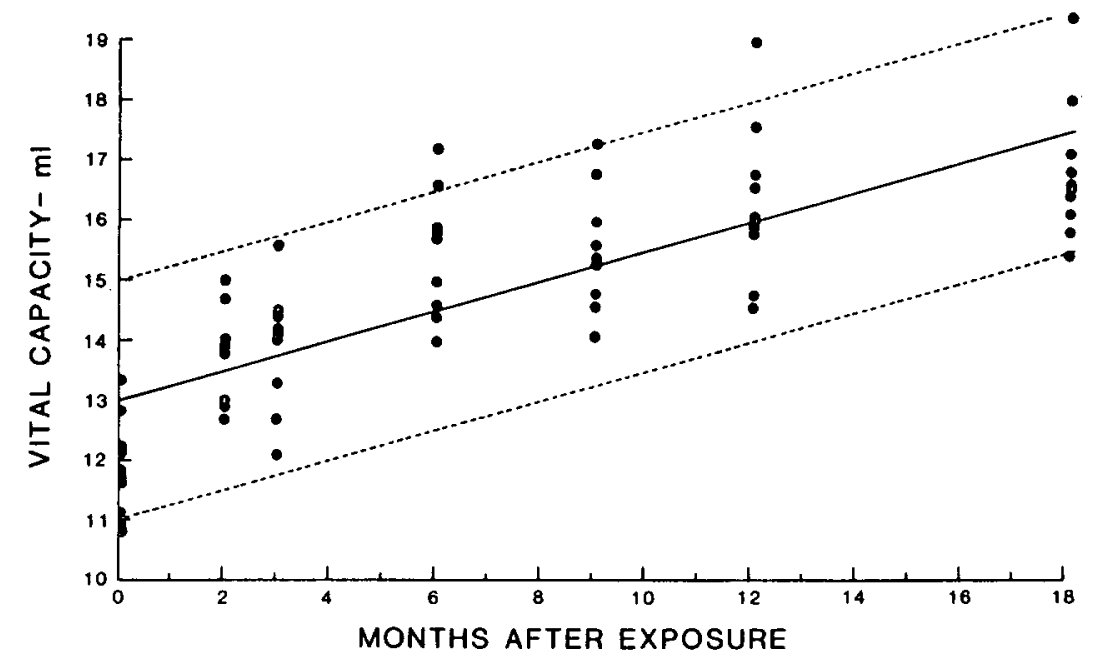

3.20 Relationship of vital capacity to age (months after exposure from age 15 weeks) for control male rats. Linear regression line with $95 \%$ confidence region.

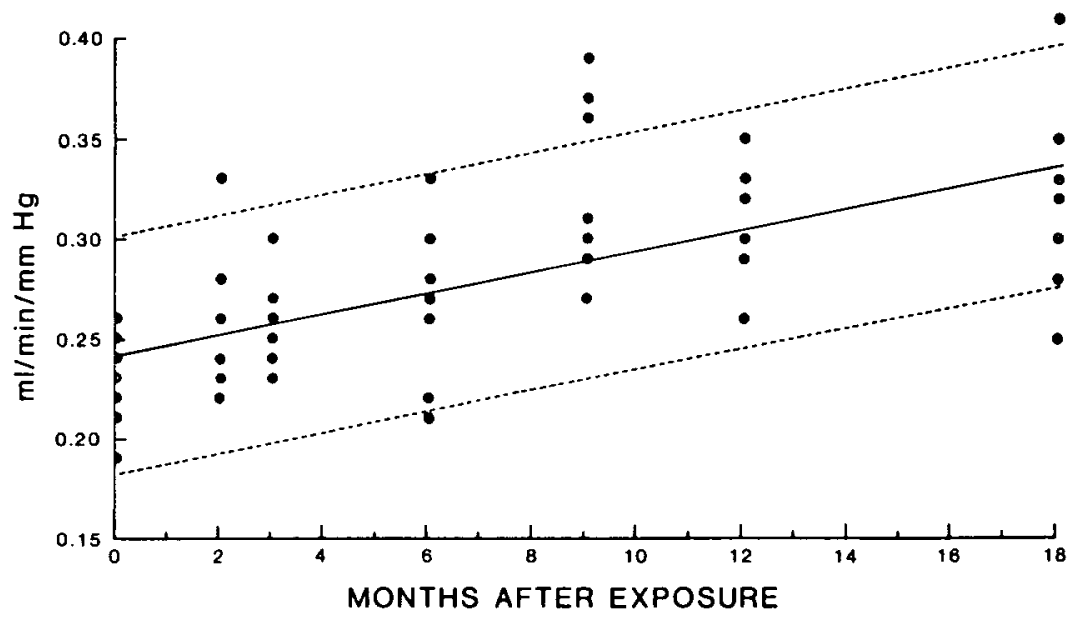

3.21 Relationship of CO diffusing capacity to age (months after exposure from age 15 weeks) for control male rats. Linear regression line with $95 \%$ confidence region.

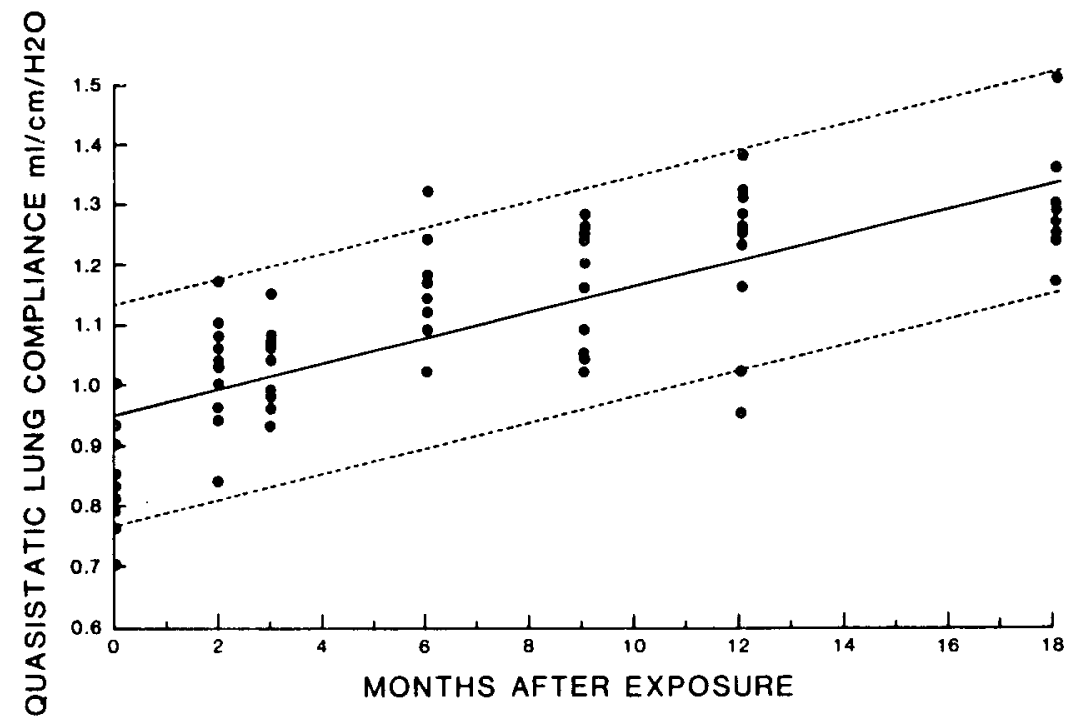

3.22 Relationship of quasistatic lung compliance to age (months after exposure from age 15 weeks) for control mae rats. Linear regression line with $95 \%$ confidence region. 


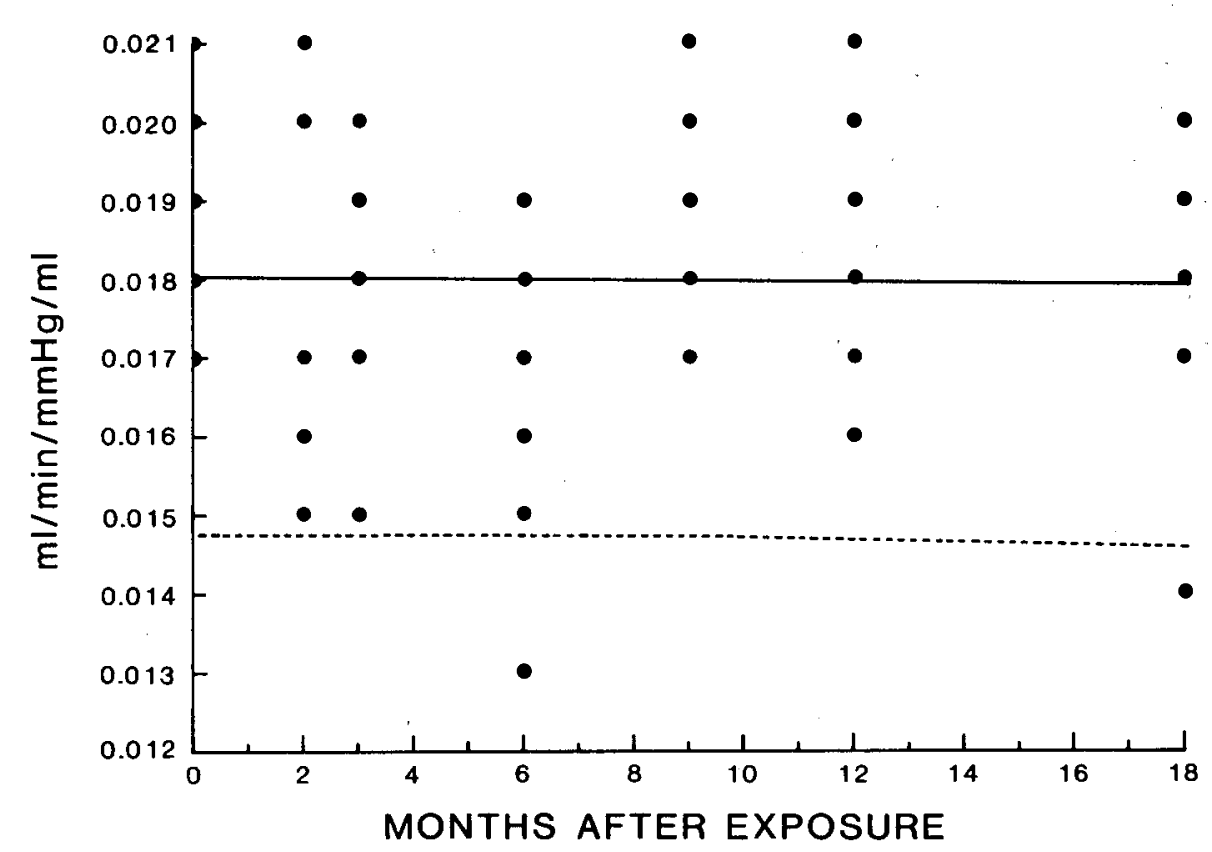

3.23 Co diffusing capacity per alveolar volume as function of age (months after exposure from age 15 weeks). Linear regression line with $95 \%$ confidence region.

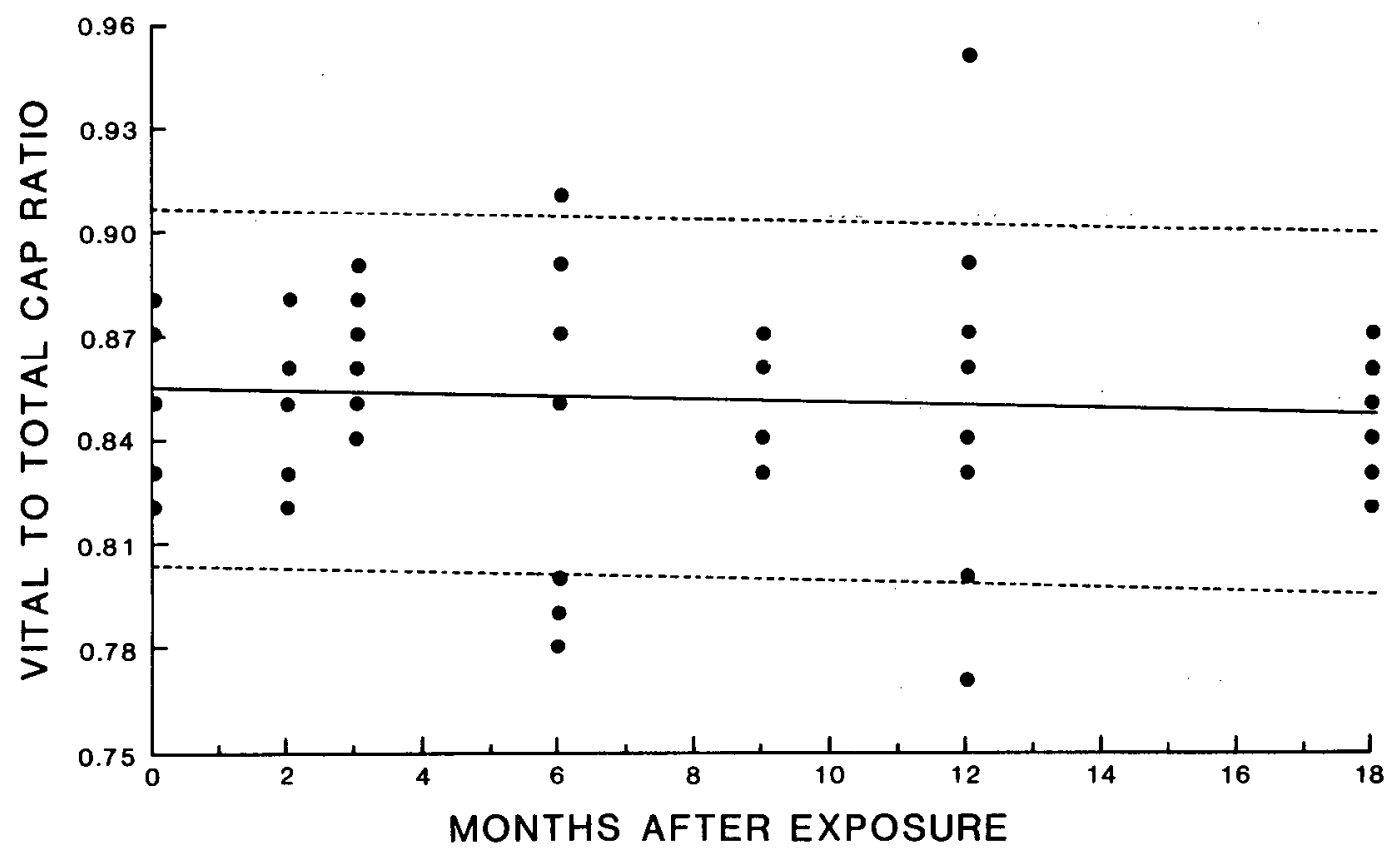

3.24 Vital capacity to total lung capacity ratio as function of age (months after exposure from age 15 weeks). Linear regression line with $95 \%$ confidence region. 
(2) those with higher dose rates and lethal doses that died within 1.5 years after exposure. Lethal doses were near the median lethal dose (370 Gy or 37,000 rad) or higher.

Dose-effect relationships for co diffusing capacity per alveolar volume are shown for rats that died within 1.5 years (Figure 3.25) and those that survived (Figure 3.26) after inhalation of ${ }^{90} \mathrm{Sr}$. The results indicate that only individuals that are exposed at high dose rates which lead to death from radiation pneumonitis are likely to have impaired co diffusing capacity. Individuals exposed at lower dose rates that do not lead to death are not likely to have such impairment. The results also indicate that individuals with lethal doses (i.e., high-dose rate exposure) can have impaired lung function at cumulative doses as low as about 150 Gy $(15,000$ rad) which is less than one-half of the estimated lethal dose. If one were able to turn off the radiation exposure at the time the cumulative dose was 150 Gy $(15,000$ rad), one would expect that those individuals with impaired pulmonary function would have survived to 1.5 years. This interpretation leads to the hypothesis that sublethal doses delivered at high dose rates can cause impaired lung function. which is supported by data for dogs and rats exposed via inhalation to $90 y$ resulting in brief irradiation of the lung.

Dose-effect relationships for co diffusing capacity per alveolar volume normalized to percent of control values (selected to demonstrate dose-effect relationships with age and sex biases removed) are given in figure 3.27 for rats surviving 1.5 years after inhalation of $90 y+$ 2.3\% ${ }^{90} \mathrm{Sr}$. Unlike the analysis of the pulmonary function data from the $90_{\mathrm{Sr}}$ study, only one group was formed: those with sublethal doses that survived to 1.5 years after exposure. Nonlethal doses as low as about 150 Gy $(15,000$ rad), $65 \%$ of the median lethal dose, caused impaired pulmonary function. This is in contrast to the results of pulmonary function tests in 1.5 year survivors after inhalation of $90 \mathrm{sr}$ where no effect on function was noted.

The results indicate that, for high dose exposure of the lung, nonlethal doses as $10 \mathrm{w}$ as $65 \%$ of the median lethal dose can cause impaired pulmonary function that is observable as late as 1.5 years after exposure. These results agree with those obtained in dogs exposed via inhalation to $90 y$ inhaled in fused aluminosilicate particles, where sublethal doses, roughly one-half the median lethal dose, caused impaired pulmonary function (Mauderly et al.., 1973). The tests used by Mauderly in dogs may have been more sensitive than those used in these studies in rats because his tests were conducted under the stress of treadmill exercise and added external respiratory dead space.

3.3.6 Mortality Data

The dose-response data for death due to radiation pneumonitis and pulmonary fibrosis included observations to 1.5 years after exposure. Using the Weibull model and a maximum likelihood procedure, the median lethal exposure dose $\left(0_{50}\right)$ and shape parameter $V$ for death from radiation pneumonitis were estimated in terms of initial lung burden for each exposure (Table 3.7). The errors represent asymptotic standard deviations. Because systematic errors in dose are not accounted for, the shape parameters should not be regarded as being different from one another. In addition, a judgement is that systematic. errors could contribute as much as 40 Gy $(4000 \mathrm{rad})$ to the error for the $\mathrm{D}_{50}$.

Dose response curves for death from radiation-pneumonitis are shown in figure 3.28 .

\subsection{DISCUSSION}

An important consideration is whether the median lethal dose for death from radiation pneumonitis is the same for the low-energy beta emitter ${ }^{147} \mathrm{Pm}$ and the high-energy beta emitter $90 \mathrm{Sr}$ (in secular equilibrium with its daughter $90 \mathrm{Y}$ ). For $147 \mathrm{Pm}$, the median lethal dose was estimated to be 310 Gy $(31,000 \mathrm{rad})$ (900 day dose) as compared to $370 \mathrm{~Gy}(37,000 \mathrm{rad})$ for $90 \mathrm{Sr}$. 


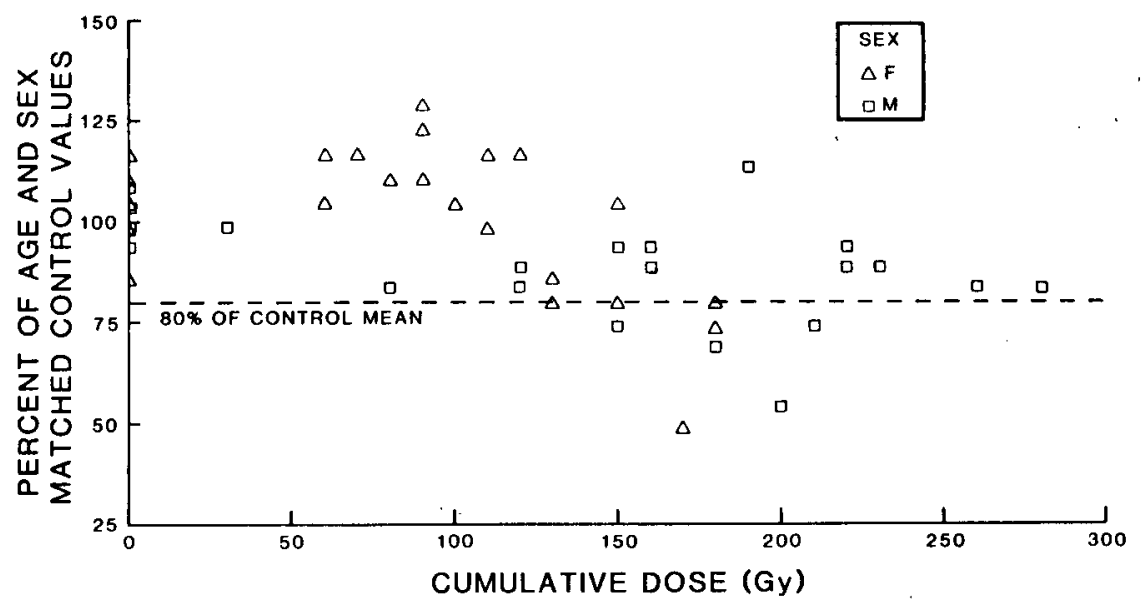

3.25 co diffusing capacity per alveolar volume vs cumulative radiation dose to the 7 ung $\mathrm{from} 90_{\mathrm{Sr}}$ for various followup times. Rats of both sexes that died within 1.5 years after exposure are included.

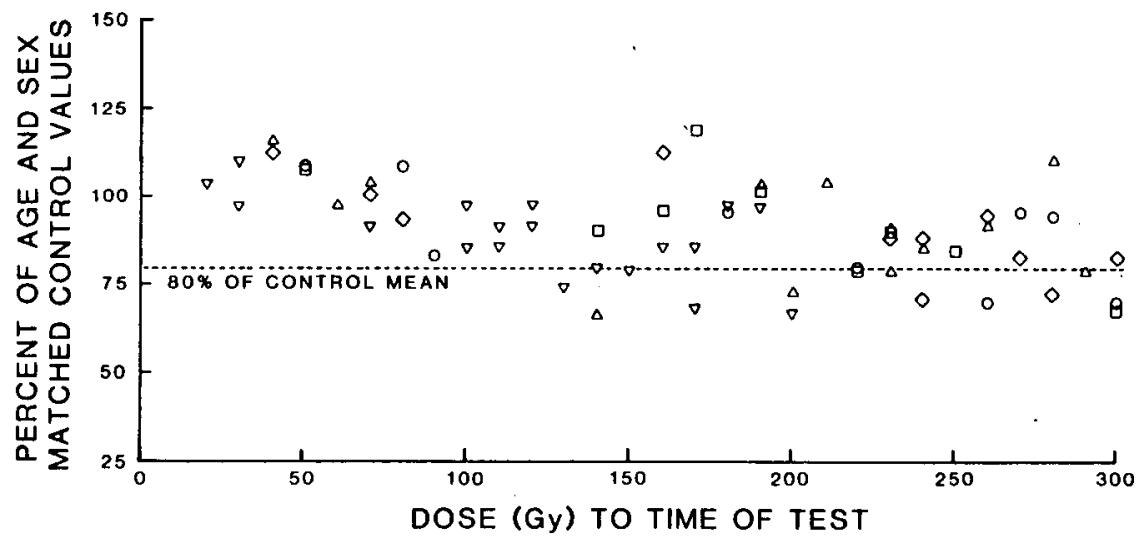

LEGEND: (MONTHS) $\quad 02 \quad 03 \quad \Delta 6 \quad 09 \quad 012$

3.26 Co diffusing capacity per alveolar volume vs cumulative radiation dose to the lung from $90 \mathrm{Sr}$ for rats of both sexes that survived to and were tested at 1.5 years after exposure.

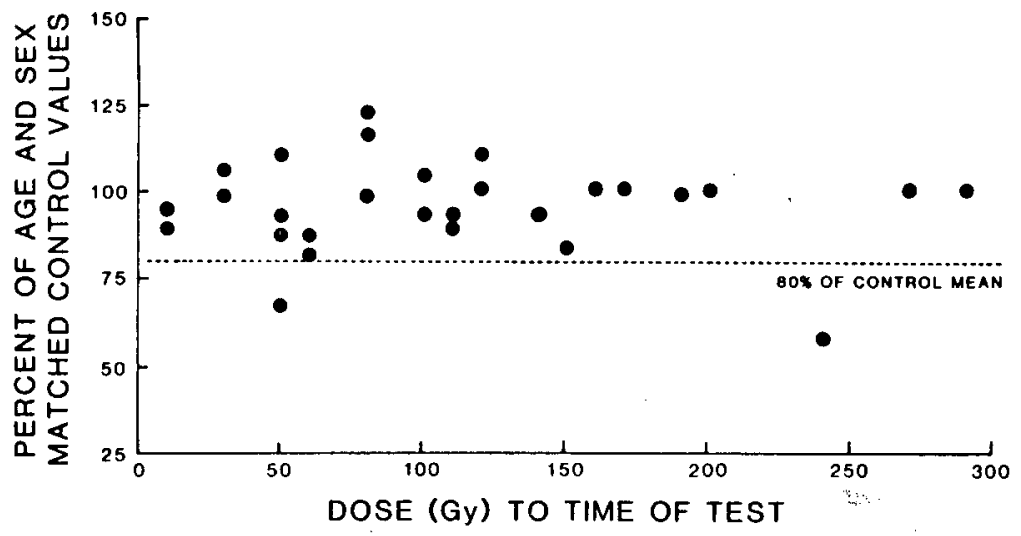

3.27 Dose-effect relationship for co diffusing capacity per alveolar volume normalized to percent of control values based on measurements obtained from rats of both sexes. Cumulative Gy to the lung from $90 y$ at the time measurements were taken are used as dose. 
The results indicate an RBE of $310 / 270=1.1$ for low-energy beta emissions from 147 Pm relative to those from $90 \mathrm{Sr}$. The results suggest that for modeling the consequences of nuclear reactor accidents, low-energy beta emitters can be treated as being equally effective as high-energy beta emitters in producing lethal injury.

Table 3.7

Summary of Various Expressions of Median Lethal Doses ( $\mathrm{D}_{50}$ )

and Shape Parameters (V) for Death From Radiation Pneumonitis and Pulmonary Fibrosis

\begin{tabular}{|c|c|c|c|c|}
\hline \multirow[b]{2}{*}{ - Radionuclide } & \multicolumn{3}{|c|}{$\mathrm{D}_{50}$ 's for Radiation Pneumonitis } & \multirow[b]{2}{*}{$\begin{array}{c}\text { Shape } \\
\text { Parameter } \\
\text { (V) }\end{array}$} \\
\hline & $\begin{array}{l}365 \text { Day } \\
\text { Dose } \\
-(G y)^{a}\end{array}$ & $\begin{array}{c}900 \text { Day } \\
\text { Dose } \\
\text { (Gy) } \\
\end{array}$ & $\begin{array}{c}\text { Initial } \\
\text { Lung Burden } \\
(\mathrm{kBq} / \mathrm{g} \text { lung })^{\mathrm{C}}\end{array}$ & \\
\hline $147 \mathrm{Pm}$ & $270 \pm 10^{b}$ & $310 \pm 11$ & $5,900 \pm 180$ & $5.4 \pm 0.9$ \\
\hline${ }^{90} \mathrm{Sr}$ & $320 \pm 10$ & $370 \pm 12$ & $1,200 \pm 40$ & $4.6 \pm 0.8$ \\
\hline $90 Y+25 \% 90 S r$ & $290 \pm 6$ & $330 \pm 7$ & $4,000 \pm 90$ & $5.6 \pm 0.9$ \\
\hline $90 Y+2.3 \% 90 S r$ & $190 \pm 7$ & $200 \pm 7$ & $10,000 \pm 360$ & $3.7 \pm 0.7$ \\
\hline
\end{tabular}

ane Gray $=100 \mathrm{rad}$.

berrors are asymptotic standard deviations.

cone $\mathrm{MBq}=27 \mu \mathrm{Ci}$.

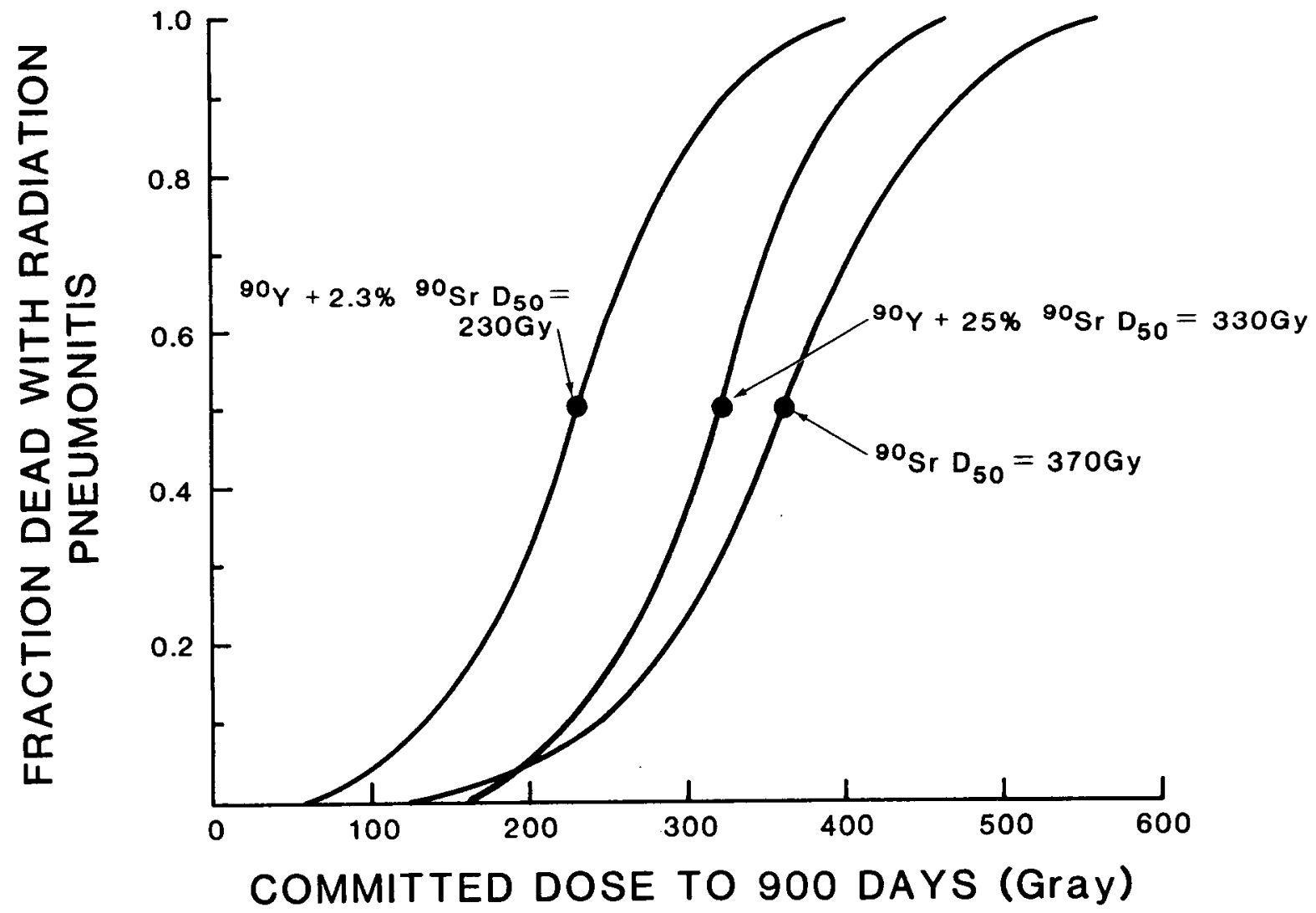

3.28 Dose response curves for death from radiation pneumonitis after inhalation of $90 \mathrm{Y}+2.3 \% 5 r$, $90 \gamma+25 \%$ sr or $90 S r$ in fused aluminosilicate particles by rats. 
CHAPTER 4

IMPLICATIONS FOR MODELING OF REACTOR ACCIDENT CONSEQUENCES

\subsection{INTROOUCTION}

In this chapter, we examine how well the hazard-function model developed at IIRI predicts deaths from radiation pneumonitis in rats. It is assumed that Beagle dogs and f344 rats are equally sensitive to the induction of radiation pneumonitis in the lungs. We show that the rat data are fully explained by the model after a systematic error in model parameters is eliminated.

Implications of the rat data to the 30-day dose lethality model (Filipy et al... 1980) are also discussed. With the 30-day dose model, the risk of death from radiation pneumonitis is estimated by the dose to the lung that accumulates in the first 30 days. With this model, it does not matter how much dose accumulates after 30 days. It is shown that the rat data for death from radiation pneumonitis do not support the 30-day dose lethality mode?.

\subsection{HAZARD FUNCTION-MODEL TESIING ANO REFINEMENTS}

With the hazard-function model, one estimates the risk of death from radiation pneumonitis in the lung from information about the pattern of dose accumulation. The modeling assumptions were that 1) different mammalian species have equal radiosensitivities to pulmonary injury and 2) they will respond in the same way when the dose accumulation patterns and radiation qualities are the same. Differences in dose-effect relationships for death from radiation pneumonitis were attributed to differences in the dose accumulation patterns when the type of radiation and other variables (e.g., age category) were held constant.

For predicting the risk of lethal injury to the bone marrow, different species were assumed to have different sensitivities and the cross-species extrapolation procedure has been described (Scott and Hahn, 1985).

4.2.1 Dose-Effect Model for Predicting the Median Lethal Dose, D50, for Radiation Pneumonitis and Pulmonary Fibrosis

The hazard-function model for death from radiation pneumonitis caused by internal beta and gamma irradiation of the lung as originally proposed allows one to predict the $0_{50}$ in terms of the 1-year dose to the lung (Scott and Hahn, 1985). Model parameters are based on limited data for dogs exposed via inhalation to beta and gamma emitters in insoluble forms. Because the studies in dogs were designed to study late-occurring effects, the data on early effects were scant, resulting in model parameters that were uncertain.

To use the model to predict the $0_{50}$ for radiation pneumonitis, one needs to know the fraction ( $f 1$ ) of the 1-year dose that would occur within the first 14 days after exposure, the fraction ( $f 2$ ) which would occur between 14 and 200 days, and the fraction ( 33 equal to 1-f1-f2) that would accumulate between 200 and 365 days.

The predicted $D_{50}$ is then obtained from the following relationship:

$$
1 / 0_{50}=f 1 / 94+f 2 / 220+f 3 / 540
$$

where the parameters 94,220 , and 540 (which represent doses to the lung in Gy) were determined from early effects data for dogs exposed via inhalation to $90 Y, 91 Y$, and ${ }^{144} \mathrm{Ce}$ inhaled in fused aluminosilicate particles. The parameters represent estimated median lethal doses for varying degrees of dose protraction.

In the $90 \mathrm{Y},{ }^{91} \mathrm{Y}$, and $144 \mathrm{Ce}$ studies in dogs, the average exposure times were about 4,80 , and 300 days, respectively. The approximately 6 -fold increase in the $0_{50}$ as the average exposure time increased from about 4 to 300 days demonstrates a dramatic dose-rate protraction effect. Such a dramatic dose-rate protraction effect cannot be explained solely in terms of an intracellular 
repair. The results suggest that other factors, such as cell turnover, may be a major contributor in the overall repair process.

The equation for predicting the $D_{50}$ is only applicable to exponentially decaying patterns of dose rates in the lung after inhalation exposure to beta- and gamma-emitting radionuclides. A fourth term is added when brief external exposure from gamma rays is a significant contributor to the total dose (Scott and Hahn, 1985) and a fifth term can be added to accommodate irradiation from inhaled alpha-emitting radionuclides. A discussion of the full model including effects in all organ systems will be provided in a subsequent NUREG document.

4.2.2 Patterns of Dose Accumulation

To predict the $D_{50}$ for death from radiation pneumonitis, one needs to know the pattern of dose accumulation in the lung to apply to the model equation. Patterns of dose accumulation for the four rat studies $\left({ }^{147} \mathrm{Pm}, 90_{S r}, 90_{Y}+2.3 \% 90 \mathrm{Sr}\right.$, and $\left.90 Y+25 \% 90 \mathrm{Sr}\right)$ are given in Figure 4.1 . values for $\mathrm{fl}, \mathrm{f2}$, and $\mathrm{f} 3$ and the predicted and observed $D_{50} \mathrm{~s}$ are given in Table 4.1 . It was assumed that the Beagle dog lung and $F 344$ rat lung were equally sensitive to the induction of radiation pneumonitis.

\subsubsection{Sample Calculation}

It is useful to provide an example of how the. D50 for death from radiation pneumonitis is predicted. The results from the ${ }^{147} \mathrm{Pm}$ study are used as an example. The fraction of the 1-year dose that would accumulate in the first 14 days is given in rable 4.1 as $f 1=0.158$. For the 14 - to 200-day time interval, one gets $f 2=0.642$. For the 200 - to 365 -day time interval, one gets $f 3=0.2$. Note that $f 1$ plus $f 2$ plus $f 3$ equals to 1 . The predicted $D_{50}$ in $G y$ is obtained from

$$
1 / D_{50}=0.158 / 94+0.642 / 220+0.2 / 540 \text {, }
$$

or

$$
1 / D_{50}=0.001681+0.002918+0.00037=0.004969 \text {. }
$$

or

$$
D_{50}=(1 / 0.004969) \text { Gy }=200 \text { Gy. }
$$

The observed $0_{50}$ (1-year dose) was obtained by multiplying the median lethal initial lung burden ( $5880 \mathrm{kBq} / \mathrm{g}$-lung) by the appropriate conversion factor ( $1.95 \mathrm{~Gy} / 37 \mathrm{kBq} / \mathrm{g}-1 \mathrm{ung}$ ) to obtain the potential infinite dose in Gy and multiplying the potential infinite dose by 0.856 to get the 1-year dose. The factor of 0.856 arises because $85.6 \%$ of the potential infinite dose accumulated in 1 year. The observed $0_{50}$ as a 1 -year dose to the lung was

$$
\text { observed } D_{50}=5880 * 1.95 * 0.856 / 37=270 \mathrm{~Gy}
$$

The ratios of the observed to the predicted $0_{50}$ was $270 / 200=1.3$.

4.2.4 Observed Vs Expected $D_{50}$ 's

Ratios of observed to predicted $D_{50}$ 's for death from radiation pneumonitis are shown in Table 4.1 for the four studies in rats. The observed-to-predicted ratio is greater than one indicating underprediction of the $D_{50}$ in each case and suggesting a systematic error. A plausible explanation for the systematic error relates to the original selection of model parameters.

Re-examination of the data from dogs exposed to inhaled beta emitters from which the model was originally derived illustrates that a systematic error was present in the definition of the parameter estimates. A recalculation of the data resulted in new parameter estimates that allow more accurate prediction of the observed $D_{50}$ doses for both dogs and rats exposed by inhalation to beta emitters.

The systematic error seems to be associated with the model parameters (94, 220, and 540) which correspond to median lethal doses (1-year doses in Gy) for dogs exposed to $90 Y, 91 Y$, and ${ }^{144} \mathrm{Ce}$ inhaled in an insoluble form. The beta dose from $90 y$ was delivered within about 14 days, the ${ }^{91 y}$ dose within about 200 days and the ${ }^{144} \mathrm{Ce}$ dose over several years. We will use the $91 \mathrm{y}$ and ${ }^{144} \mathrm{Ce}$ studies to demonstrate a bias in the model parameter estimates. 


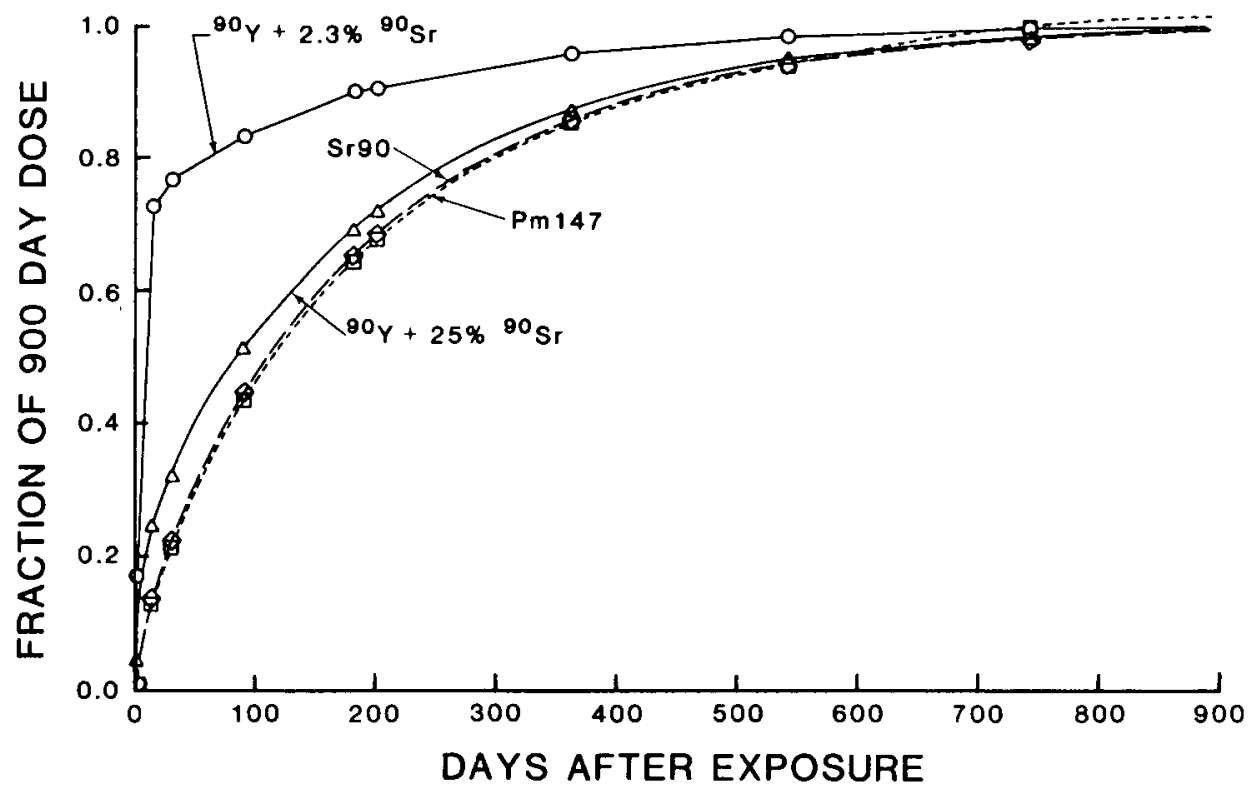

4.1 Dose accumulation pattern after inhalation of $147 \mathrm{Pm}, 90 \mathrm{Sr}, 90 \mathrm{Y}+2.3 \% 90 \mathrm{Sr}, 0 \mathrm{O}=90 \mathrm{Y}+25 \%$ $90 \mathrm{Sr}$ inhaled in fused aluminosilicate particles.

For the $91 y$ study, the radioactivity in dog lung decreased exponentially with a half-time of approximately 53 days so that $f 1=0.169, f 2=0.765$ and $f 3=0.066$. The expected $D_{50}$ was calculated using

$$
1 / 0_{50}=0.169 / 94+0.765 / 220+0.066 / 540
$$

or

$$
D_{50}=190 \text { Gy }(19,000 \mathrm{rad}) \text {. }
$$

The observed median lethal dose was approximately 220 Gy $(22,000$ rad $)$. This predicted D50 is biased downward by a factor of $220 / 190=1.2$.

For the ${ }^{144} \mathrm{Ce}$ study, the radioactivity in dog lung decreased exponentially with a half-time of approximately 200 days so that $f 1=0.066, f 2=0.63$ and $f 3=0.304$. The expected $0_{50}$ was calculated using

$$
1 / 0_{50}=0.066 / 94+0.63 / 220+0.304 / 540
$$

or

$$
D_{50}=240 \mathrm{~Gy}(24,000 \mathrm{rad})
$$

The observed median lethal dose was approximately $540 \mathrm{~Gy}(54,000 \mathrm{rad})$. This predicted $0_{50}$ is also biased downward by a factor of $540 / 240=2.2$. We can easily correct for the bias using the average bias of $(1.2+2.2) / 2=1.7$. Multiplying each of the model parameters 94,220 , and 540 by 1.7 and rounding leads to the bias-adjusted equation

$$
1 / 0_{50}=f 1 / 160+f 2 / 370+f 3 / 920 .
$$


Table 4.1

Expected and Observed Median Lethal Doses for Death from Radiation Pneumonitisa

\begin{tabular}{|c|c|c|c|c|c|c|c|c|c|c|}
\hline \multirow{4}{*}{ Radionuc lide } & \multirow{3}{*}{\multicolumn{3}{|c|}{$\begin{array}{l}\text { Fraction of } \\
\text { 1-Year Dose }\end{array}$}} & \multirow{3}{*}{\multicolumn{3}{|c|}{$\begin{array}{c}\text { Normalized Fractions } \\
\left(\mathrm{Gy}^{-1}\right)\end{array}$}} & \multirow{4}{*}{$\begin{array}{l}\text { Sum of } \\
\text { Normalized } \\
\text { : } \\
\text { Fractions } \\
\text { (F) }\end{array}$} & \multirow{2}{*}{\multicolumn{2}{|c|}{$0_{50}(1 \text {-Year Gy })^{b}$}} & \multirow{4}{*}{ Observe } \\
\hline & & & & & & & & & & \\
\hline & & & & & & & & \multirow{2}{*}{$\begin{array}{l}\text { Expected } \\
(1 / F) \\
\end{array}$} & \multirow[b]{2}{*}{ observed } & \\
\hline & $\mathrm{fl}$ & $\mathrm{f} 2$ & $f 3$ & fl/ $/ 94$ & $\mathrm{f} 2 / 220$ & $\mathrm{f} 3 / 540$. & & & & \\
\hline $147 \mathrm{Pm}$ & 0.158 & 0.642 & 0.200 & 0.00168 & 0.00292 & 0.00037 & 0.00497 & 200 & 270 & 1.3 \\
\hline${ }^{90} \mathrm{sr}$ & 0.137 & 0.678 & 0.185 & 0.00146 & 0.00308 & 0.00034 & 0.00488 & 2.10 & 320 & 1.5 \\
\hline${ }^{90} Y Y+2.3 \%{ }^{90} S r$ & 0.758 & 0.188 & 0.054 & 0.00806 & 0.00085 & 0.00010 & 0.00901 & 110 & 190 & 1.7 \\
\hline $90 Y+25 \%{ }^{90} S r$ & 0.284 & 0.543 & 0.173 & 0.00302 & 0.00247 & 0.00032 & 0.00581 & 170 & 290. & 1.7 \\
\hline
\end{tabular}

a Based on model $1 / 0_{50}=f 1 / 94+f 2 / 220+f 3 / 540$. See text for explanation.

bone Gray $=100 \mathrm{rad}$. 
Table 4.2

Expected and Observed Median Lethal Doses for Death from Radiation Pneumonitis Based on Bias Adjusted Formulaea

\begin{tabular}{|c|c|c|c|c|c|c|c|c|c|c|c|}
\hline \multirow{3}{*}{\multicolumn{2}{|c|}{ Radionuclide }} & \multirow{2}{*}{\multicolumn{3}{|c|}{$\begin{array}{l}\text { Fraction of } \\
1 \text {-Year Dose }\end{array}$}} & \multirow{2}{*}{\multicolumn{3}{|c|}{$\begin{array}{l}\text { Normalized Fractions } \\
\qquad\left(G y^{-1}\right)\end{array}$}} & \multirow{3}{*}{$\begin{array}{l}\text { Sum of } \\
\text { Normalized } \\
\text { Fractions } \\
\text { (F) }\end{array}$} & \multicolumn{2}{|c|}{$D_{50}(1-\text { Year Gy })^{b}$} & \multirow{3}{*}{$\begin{array}{l}\text { Observed } \\
\text { Expected }\end{array}$} \\
\hline & & & & & & & & & \multirow{2}{*}{$\begin{array}{l}\text { Expected } \\
(1 / F)\end{array}$} & \multirow[b]{2}{*}{ observed } & \\
\hline & & fi & +2 & $\mathbf{f 3}$ & $f 1 / 160$ & $千 2 / 370$ & $f 3 / 920$ & & & & \\
\hline & ${ }^{147} \mathrm{Pm}$ & 0.158 & 0.642 & 0.200 & 0.00099 & 0.00174 & 0.000217 & 0.00295 & 340 & 270 & 0.80 \\
\hline & $90 s r$ & 0.137 & 0.678 & 0.185 & 0.00086 & 0.00183 & 0.000201 & 0.00289 & 350 & 320 & 0.91 \\
\hline & $90 Y Y+2.3 \%{ }^{90} S r$ & 0.758 & 0.188 & 0.054 & 0.00474 & 0.00051 & 0.000059 & 0.00531 & 190 & 190 & 1.0 \\
\hline & ${ }^{90} Y+25 \%{ }^{90} S r$ & 0.284 & 0.543 & 0.173 & 0.00178 & 0.00147 & 0.000188 & 0.00344 & 290 & 290 & 1.0 \\
\hline
\end{tabular}

a Based on model $1 / D_{50}=f 1 / 160+f 2 / 370+f 3 / 920$. See text for explanation.

bone Gray $=100 \mathrm{rad}$. 
Predicted and observed $0_{50}$ 's for death from radiation pneumonitis for the four studies in rats, based on the above modified equation are given in Table 4.2 and are in excellent agreement. Recall that none of the data for rats was used to make predictions. The agreement between observed and expected $D_{50}$ 's suggest that the revised model should be adequate for reactor accident consequence modeling when only internal low-LET radiation is of concern.

4.2.5 30-Day Dose Lethality Model

According to the 30 -day dose lethality model, the 30 -day dose determines the lethality risk regardless of the pattern of dose accumulation in the lung. With this model. the $0_{50}{ }^{\prime} s$ should be the same for all four studies, when expressed in terms of the 30-day dose to the lung. Table 4.3 provides values for the $D_{50}$ expressed in 30-day and 1 -year doses to the lung for the four rat studies. Using the 30-day dose model, one would conclude that more low-LET dose is needed to cause lethality when the average dose rates are the highest ( $90 \mathrm{Y}$ study) than when they are the lowest $(147 \mathrm{Pm}$ and $90 \mathrm{Sr}$ studies). Such a conclusion is contradicted by an overwhelming body of data on dose rate effects of low-LET radiation (NCRP 64, 1980) and the results of these studies.

4.2.6 Predicting Risks with the Hazard Function Model

To predict the risk of dying from radiation pneumonitis using the hazard function model, a second model parameter, the shape parameter $v$, is also needed in addition to the $D_{50}$. As shown in Table 3.7, values for $V$ for the four rat studies were quite similar suggesting that for beta irradiation, the shape parameter does not depend on dose rate pattern. The average value for $v$ from the four studies with beta radiation was approximately 5 , which is slightly larger than the value of 4 previously used (Scott and Hahn, 1985). With a value of 5 , fewer deaths would be expected in the lower tail region of the dose-effect curve than if a value of 4 was used. There is some evidence that the dose-effect curve may be considerably steeper for gamma radiation with $V$ being approximately 10 ( $5 c o t t$ et al., 1986).

To calculate the predicted risk, one can first calculate the expected $0_{50}$ using the relationship presented earlier. Once the $D_{50}$ is known, the risk of death from radiation pneumonitis is given by

$$
\text { Risk }=1-\exp [-H]
$$

where

$$
H=0.693\left[D_{0} / D_{50}\right]^{V}
$$

where $D$ is the calculated 1 -year dose to the lung in Gy.

Table 4.3

\begin{tabular}{|c|c|c|c|c|c|}
\hline \multirow[b]{3}{*}{ Study } & \multicolumn{5}{|l|}{ Initial } \\
\hline & \multirow{2}{*}{$\begin{array}{l}\text { Lung Burden } \\
\mathrm{MBg} / \mathrm{g} \text { Lung }\end{array}$} & \multicolumn{4}{|c|}{ Calculated Dose (Gy) } \\
\hline & & 30 Day & 365 Day & 540 Day & 900 Day \\
\hline $90 y+2.3 \% 90 S r$ & 10 & $16 \pm 5.5$ & 190 & 200 & 200 \\
\hline $90 Y+25 \% 90 S r$ & 4.0 & $11 \pm 2.3$ & 290 & 310 & 330 \\
\hline $90 S r$ & 1.2 & $7.9 \pm 2.5$ & 320 & 350 & 370 \\
\hline $147 \mathrm{Pm}$ & 5.9 & $6.9 \pm 2.1$ & 270 & 290 & 310 \\
\hline
\end{tabular}

Comparison of Median Lethal Dose to Cause Death from Radiation Pneumonitis

a One Gray $=100 \mathrm{rad}$.

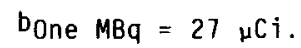




\subsection{MORBIDITY DATA IMPLICATIONS}

Three classes of morbidity data were examined: body weight, hematological parameters, and pulmonary function. The major implications of the data are discussed below.

\subsubsection{Body Weight Data}

Effects on body weight were mainly observed in rats receiving radiation induced lethal injury to the lung. For these rats, there was a period before development of lethal injury in which lethal doses accumulated and where their body weights increased. After receiving lethal injury and becoming sick, there was a plummeting in their body weight. This phenomenon occurred primarily at doses near the median lethal dose or higher. The implication of these results is that body weight is a measure of morbidity only for those individuals that are likely to have lethal injury.

Having both nonsurvivors and survivors in a dose group can lead to a short plateau in the average weight-gain vs time relationship, with the plateau corresponding to the time that the deaths from radiation pneumonitis occurred. Individuals with sublethal doses continued to gain weight in a similar fashion as unirradiated controls.

At doses approximately 2 times higher than the median lethal dose (supralethal doses), all rats died from early effects of irradiating the lung. For those rats, there was a transient increase in body weight over a short time period followed by a plummeting in the weights of all rats to values less than their initial weight.

\subsubsection{Hematology Data}

Effects on the hematopoietic system were only demonstrated for rats that inhaled the relatively high energy beta emitters $90 \mathrm{Sr}, 90 \mathrm{Y}$, or $90_{\mathrm{Y}}+90_{\mathrm{Sr}}$. The low energy betas from $147 \mathrm{Pm}$ were apparently not energetic enough to reach critical targets suggesting that the critical targets were in the bone marrow rather than blood passing through the lung.

An important consideration in light of these data is whether or not irradiation of the bone marrow can affect lung sensitivity to induction of radiation pneumonitis. If significant injury to the bone marrow occurred so as to make the lung more sensitive (cross-organ interaction effect), then the $0_{50}$ for lethality from radiation pneumonitis should be greater for $147 \mathrm{Pm}$ than that for $90 \mathrm{Sr}$, because of the higher beta energies from $90 \mathrm{Sr}$. The $90 \mathrm{Sr}$ and $147 \mathrm{Pm}$ studies are appropriate to compare because dose-rate patterns were similar in the two studies, while $905 r$ has an average beta energy of $1.13 \mathrm{MeV}(0.935 \mathrm{MeV}$ from daughter $90 \mathrm{Y}$ and $0.196 \mathrm{MeV}$ from $90 \mathrm{Sr}$ parent) as compared to the $0.062 \mathrm{MeV}$ average beta energy for $147 \mathrm{Pm}$. Instead of the $\mathrm{D}_{50}$ for $147 \mathrm{Pm}$ being greater than that for ${ }^{90} \mathrm{Sr}$, it was about 1.2 times smaller, suggesting that a synergistic effect due to irradiation of both the lung and bone marrow did not occur in the dose range studied in the ${ }^{90} \mathrm{sr}$ study. The results suggest that, while a temporary decrease in blood lymphocyte counts was demonstrated in rats exposure to high-energy beta radiation from the lung, the decrease had no observable effect on the induction of radiation pneumonitis.

These results do not mean that irradiation of the lung from internal emitters cannot affect sensitivity of an individual to whole-body irradiation where injury to the bone marrow may be the cause of death; current experiments at the Pacific Northwest Laboratory will clarify whether irradiation of the lung can affect the $D_{50}$ for lethality from injury to the bone marrow. One might expect such an interaction effect could occur when exposed from both external photon radiation (total-body) and from internal inhaled radionuclides. Such an interaction could occur because of the role granulocytes play in protecting the body from infections. Irradiation of the lung could make infection more likely, so that when coupled with serious reduction in granulocyte cellularity by external radiation, could lead to a significant cross organ interaction. If such an interaction is demonstrated to be quantifiable and significant, a term could be added to the hazard function model to account for it. 


\subsubsection{Pulmonary Function Data}

Pulmonary function measurements were recorded in the ${ }^{90} \mathrm{Sr}$ and $90 \mathrm{Y}$ studies. Dose-effect relationships for various followup times were constructed using the diffusing capacity per alveolar volume normalized as a percent of the control values. As in humans, individuals with less than $80 \%$ of the control value were judged to have impaired pulmonary function. The data clearly demonstrated that for short lived radionuclides, such as $90 y$ which generate doses at relatively high dose rates, sublethal doses can cause impaired pulmonary function. The data also demonstrated that the long-lived radionuclide $90 \mathrm{Sr}$ which generate doses at relatively lower dose rates than $90 Y$, mainly produce impaired pulmonary function among individuals with initial dose rate high enough to produce about 150 Gy $(15,000$ rad) or more (cumulative dose) within about 2 months after exposure. However, these dose rates were high enough that lethal doses were eventually acquired by all individuals showing impaired pulmonary function at early times. 
VI. REFERENCES

1. Collis, C. H. and Steel, G. G. (1982): Dose-Dependence of the Time of Appearance of Lung Damage in Mice Given Thoracic Irradiation. Int. J. Radiat. Biol. 42: 245-252.

2. Crow, L. C., Davis, F. A., and Maxfield, M. W. (1960): Statistical Manual, Dover, New York, NY.

3. Depledge, M. H. and Barrett, A. (1982): Dose-Rate Dependence of Lung Damage After Total-Body Irradiation in Mice. Int. J. Radiat. Biol. 41:325-334.

4. Filipy, R. E., Borst, F. J., Cross, F. T., Park, J. F., Moss, 0. R., Roswell, R. L., and Stephens, D. L. (1980): A Mathematical Model for Predicting the Probability of Acute Mortality in Human Population Exposure to Accidentally Released Airborne Radionuclides. Final Report of Phase I of the Project: Early Effects of Inhaled Radionuclides. NURÉG/CR-1261, PNL 3257.

5. Gross, N. J. (1981): The Pathogenesis of Radiation-Induced Lung Damage. Lung 159: 115-125.

6. Gross, N. J. (1977): Pulmonary Effects of Radiation Therapy. Ann. Intern. Med. 86: 81-92.

7. Hahn, F. F. (1979): Early Mortality Estimates for Different Nuclear Accidents. Final Phase 1 Report. NUREG/CR-0774.

8. Harkema, J. R., Mauderly, J. L., and Hahn, F. F. (1982): The Effects of Emphysema on 0xygen Toxicity in Rats. Am. Rev. Respir. Dis. 126: 1058-1065.

9. Lundgren, D. L., Hahn, F. F., and MCClellan, R. 0. (1980): Repeated Inhalation Exposure of Rats to Aerosols of ${ }^{144} \mathrm{CeO}_{2}$. In Inhalation Toxicology Research Institute Annual Report 1979-1980, LMF-84, pp. 95-98.

10. Mauderly, J. L. (1982): The Effect of Age on Respiratory Function of Fischer-344 Rats. Experimental Aging Research 8: 31-36.

11. Mauderly, J. L., Muggenburg, B. A., Hahn, F. F., and Boecker, B. B. (1980): The Effects of Inhaled ${ }^{144} \mathrm{Ce}$ on Cardiopulmonary Function and Histopathology of the Dogs. Radiat. Res. 84: $307-324$.

12. Mauderly, J. L., Pickre11, J. A., Hobbs, C. H., Benjamin, S. A., Hahn, F. F., Jones, R. K., and Barnes, J. E. (1973): The Effects of Inhaled Y-90 Fused Clay Aerosol on Pulmonary Function and Related Parameters of the Beagle Dogs. Radiat. Res. 56: 83-96.

13. Mcclellan, R. O., Boecker, B. B., Cuddihy, R. G., Griffith, W. C., Hahn, F. F., Muggenburg, B. A., Scott, B. R., and Seiler, F. A. (1982): Health Effects from Internally Deposited Radionuclides Released in Nuclear Disasters. In the Control of Exposure of the Public to Ionizing Radiation in the Event of Accident or Attack. Proceedings of a Symposium Sponsored by the National Council on Radiation Protection and Measurements. Reston, VA, April 27-29, 1981, pp. 28-39.

14. NCRP Report 64 (1980): Influence of Dose and Its Distribution in Time on Dose Response Relationships for Low LET Radiation. NCRP, Washington, OC.

15. Phillips, T. L. and Margolis, L. (1972): Radiation Pathology and the Clinical Response of Lung and Esophagus. Front. Radiat. Ther. Oncol. 6: 254-273.

16. SAS (1982): SAS User's Guide: Statistics. SAS Institute, Cary, NC.

17. Scott, B. R. and Hahn, F. F. (1985): Early Occurring and Continuing Effects. In Health Effects Model for Nuclear Power Plant Accident Consequence Analysis, Volume II, Chapter 1. NUREG/CR-4214, SAND85-7185.

18. Slauson, D. 0., Hahn, F. F., Benjamin, S. A., Chiffelle, T. L., and Jones, R. K. (1976): Inflammatory Sequences in Acute Pulmonary Radiation Injury. Am. J. Pathol. 82: 549-572.

19. Slauson, D. O., Hahn, F. F., and Chiffelle, T. L. (1977): The Pulmonary Vascular Pathology of Experimental Radiation Pneumonitis. Am. J. Pathol. 88: 635-654. 
20. Snipes, M. B. (1980): Fraction of Energy Absorbed from B-emitting Particles in the Rat Lung. Radiat. Res. 81:161-169.

21. Travis, E. L., Parkins, C. S., Down, J. D., Fowler, J. F., and Thames, H. 0. (1983): Repair in Mouse Lung Between Multiple Small Doses of X-Rays. Radiat. Res. 94: 3?6-339.

22. Van Dyk, J., Keane, T. J., Kan, S., Rider, W., and Fryer, C. J. H. (1981): Radiation Pneumonitis Following Large Single-Dose Irradiation: A Re-evaluation Based on Absolute Dose to Lung. Int. J. Radiat. Oncol. Biol. Phys. 7: 461-467.

23. WASH 1400 (1975): Reactor Safety Study, An Assessment of Accident Risk in U. S. Commercial Nuclear Power Plants, U. S. Nuclear Regulatory Commission. 
APPENDIX: DATA BASES

Listing of rats exposed to aerosols of beta-emitting radionuclides in fused aluminosilicate particles (FAP).

1. Rats exposed to aerosols of $147 \mathrm{Pm}$ FAP

2. Rats exposed to aerosols of $90 \mathrm{Sr}$ FAP

3. Rats exposed to aerosols of $90 \mathrm{Y}$ FAP

4. Rats exposed to aerosols of $90 \mathrm{Y} / 90_{\mathrm{Sr}} \mathrm{FAP}$

5. Pulmonary function measurements in rats exposed to aerosols of $90 \mathrm{Sr}$ FAP 


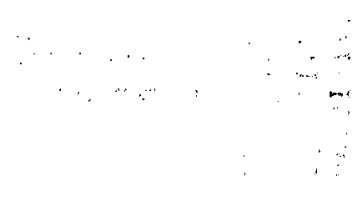

- $\quad$
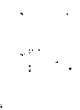
EXPERI

\begin{tabular}{|c|c|c|c|}
\hline $\begin{array}{l}\text { ANIMAL } \\
\text { NUMBER }\end{array}$ & $\begin{array}{l}\text { EXPERI- } \\
\text { MENT } \\
\text { NUMBER }\end{array}$ & SEX & GROUP \\
\hline 140 & 3230 & $\mathrm{~F}$ & HEMATOLOGY \\
\hline $\begin{array}{l}149 \\
168\end{array}$ & $\begin{array}{l}3230 \\
3230\end{array}$ & $F$ & $\begin{array}{l}\text { HEMATOLOGY } \\
\text { HEMATOLOGY }\end{array}$ \\
\hline 187 & 3230 & $M$ & HEMATOLOGY \\
\hline 226 & 3230 & M & HEMATOLOGY \\
\hline 233 & 3230 & $M$ & HEMATOLOGY \\
\hline $\begin{array}{l}276 \\
329\end{array}$ & $\begin{array}{l}3230 \\
3230\end{array}$ & $\mathrm{~F}$ & $\begin{array}{l}\text { HEMATOLOGY } \\
\text { HEMATOLOGY }\end{array}$ \\
\hline 177 & 3230 & M & HEMATOLOGY \\
\hline 235 & 3230 & M & HEMATOLOGY \\
\hline $\begin{array}{l}313 \\
165\end{array}$ & $\begin{array}{r}3230 \\
3230\end{array}$ & F & $\begin{array}{l}\text { HEMATOLOGY } \\
\text { HEFATOLO }\end{array}$ \\
\hline $\begin{array}{l}165 \\
369\end{array}$ & $\begin{array}{l}3230 \\
3230\end{array}$ & $\begin{array}{c}M \\
F\end{array}$ & $\begin{array}{l}\text { HEMATOLOGY } \\
\text { HEMATOLOGY }\end{array}$ \\
\hline & 3230 & $\begin{array}{l}\mathrm{F} \\
\mathrm{F}\end{array}$ & HEMATOLOGY \\
\hline 244 & 3230 & M & HEMATOLOGY \\
\hline 161 & 3230 & M & HEMATOLOGY \\
\hline $\begin{array}{l}278 \\
354\end{array}$ & $\begin{array}{r}3230 \\
3230\end{array}$ & F & $\begin{array}{l}\text { HEMATOLOGY } \\
\text { HEMATOLOGY }\end{array}$ \\
\hline $\begin{array}{l}354 \\
116\end{array}$ & 3230 & $M$ & HEMA TOLOGY \\
\hline 316 & 3230 & $\mathrm{~F}$ & HEMATOLOGY \\
\hline 122 & 3230 & M & HEMA TOLOGY \\
\hline 290 & 3230 & M & HEMATOLOGY \\
\hline $\begin{array}{l}322 \\
205\end{array}$ & $\begin{array}{l}3230 \\
3230\end{array}$ & $\begin{array}{l}F \\
F\end{array}$ & $\begin{array}{l}\text { HEMAODLOGY } \\
\text { HEMATOLOGY }\end{array}$ \\
\hline 107 & 3230 & M & HEMATOLOGY \\
\hline $\begin{array}{l}195 \\
338\end{array}$ & $\begin{array}{l}3230 \\
2232\end{array}$ & $\mathrm{~F}$ & $\begin{array}{l}\text { HEMATOLOGY } \\
\text { HEMAT }\end{array}$ \\
\hline $\begin{array}{l}338 \\
336\end{array}$ & $\begin{array}{l}3230 \\
3230\end{array}$ & $\begin{array}{l}F \\
F\end{array}$ & $\begin{array}{l}\text { HEMATOOLOGY } \\
\text { HEMATOLOGG }\end{array}$ \\
\hline 213 & $\begin{array}{l}3230 \\
3230\end{array}$ & F & HEMATOLOGY \\
\hline 247 & 3230 & $M$ & HEMATOLOGY \\
\hline 123 & 3230 & M & HEMATOLOGY \\
\hline 272 & 3230 & $\mathrm{~F}$ & HEMA TOLOGY \\
\hline $\begin{array}{l}136 \\
232\end{array}$ & $\begin{array}{l}3230 \\
2320\end{array}$ & $F$ & HEMATOLOGY \\
\hline $\begin{array}{l}221 \\
280\end{array}$ & $\begin{array}{l}3230 \\
3230\end{array}$ & $M$ & HEMA TOLOGY \\
\hline 181 & 3230 & M & $\begin{array}{l}\text { HEMA OLOGY } \\
\text { HEMATOLOGY }\end{array}$ \\
\hline 159 & 3230 & $\mathrm{~F}$ & HEMATOLOGY \\
\hline 108 & 3230 & M & MORTALITY \\
\hline 147 & 3230 & $\mathrm{~F}$ & MORTALITY \\
\hline 148 & 3230 & $\mathrm{~F}$ & MORTALITY \\
\hline $\begin{array}{l}150 \\
150\end{array}$ & $\begin{array}{l}3230 \\
2320\end{array}$ & F & MORTALITY \\
\hline 151 & $\begin{array}{l}3230 \\
2320\end{array}$ & $F_{4}$ & MORTALITY \\
\hline $\begin{array}{l}106 \\
172\end{array}$ & 3230 & $M$ & MORTALITY \\
\hline 173 & 3230 & M & MORTALIIY \\
\hline $\begin{array}{l}189 \\
207\end{array}$ & $\begin{array}{r}3230 \\
2320\end{array}$ & $M$ & MORTALI IY \\
\hline 212 & 3230 & F & MORTALITY \\
\hline 215 & $\begin{array}{l}3230 \\
3230\end{array}$ & F & MORTALITY \\
\hline & & & \\
\hline
\end{tabular}

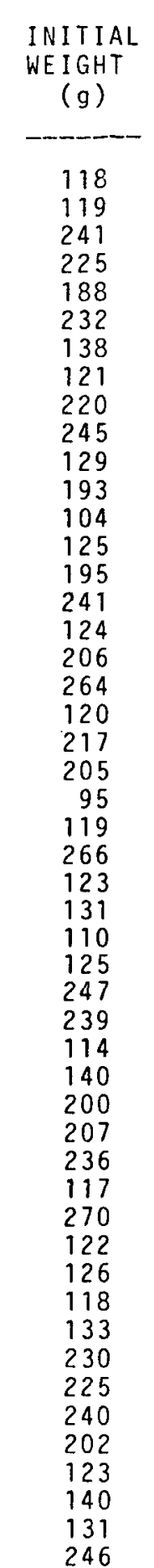

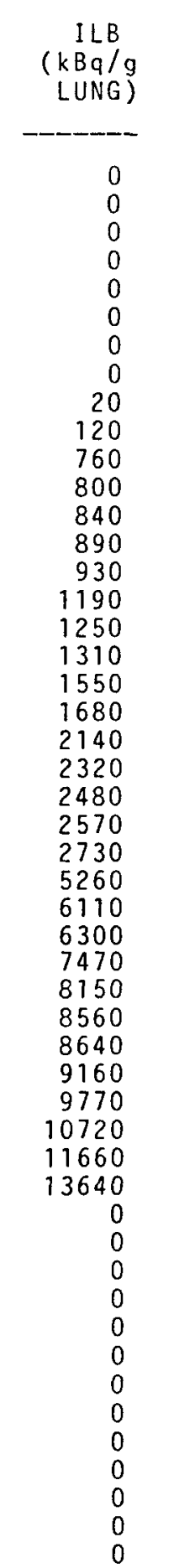

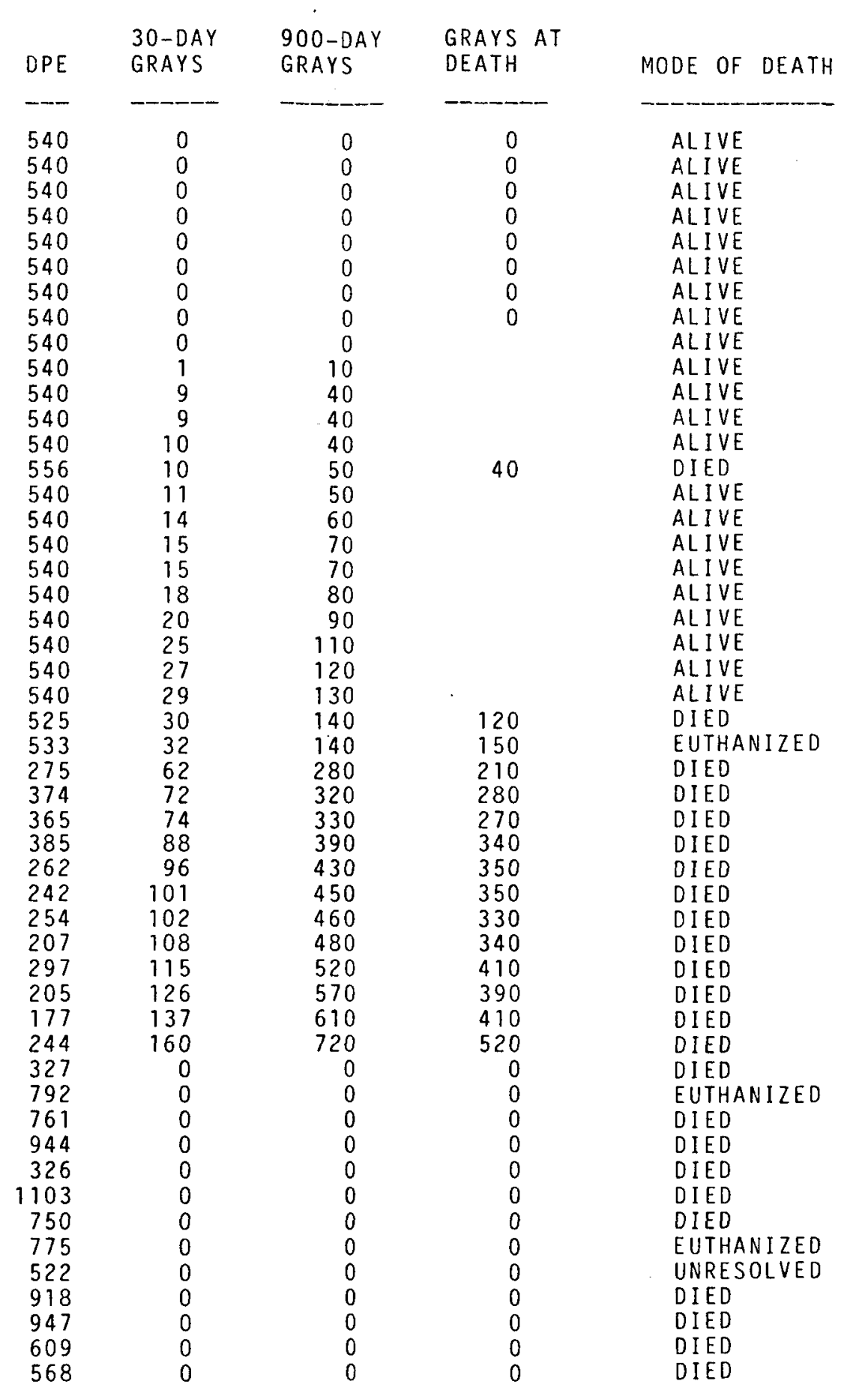

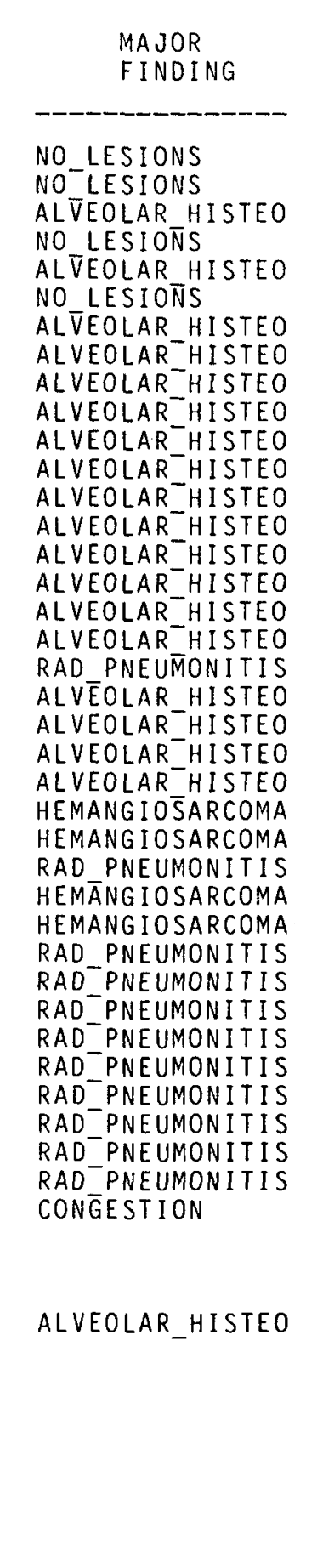

\section{SEPT_FIBROSIS}

\section{SEPT FIBROSIS
SEPT FIBROSIS}

SEPT_FIBROSIS, SQUAM_CELL_PAP SQUAM CELL CA
SEPT FIBROSIS

RAD_PNEUMONITIS. SEPT FIBROSIS

RAD PNEUMONITIS, SEPT-FIBROSIS

SEPT FIBROSIS SAD SEPUMONITIS. SEPT FIBROSIS, HEMORRHAGE RAD PNEUMONITIS, SEPT_FIBROSIS, HEMORRHAGE
RAD PNEUMONTIS. SEPT-FIBROSIS. HEMORRHAGE SEPT F F BROSIS
SEPT FIBROIS
SEPT-FIBROSIS

SEPT FIBROSIS

SEPT FIBROSIS

SEPT FIBROSIS 


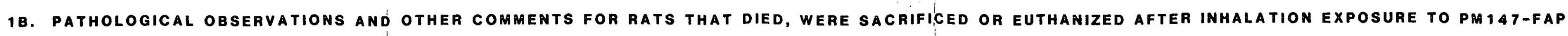

\begin{tabular}{|c|c|c|c|c|c|c|c|c|c|c|c|c|}
\hline $\begin{array}{l}\text { ANIMAL } \\
\text { NUMBER }\end{array}$ & $\begin{array}{l}\text { EXPERI- } \\
\text { MENT } \\
\text { NUMBER }\end{array}$ & SEX & GROUP & $\begin{array}{l}\text { INI I IAL } \\
\text { WEIGHT } \\
(\mathrm{g})\end{array}$ & $\begin{array}{c}\mathrm{ILB} \\
(\mathrm{kBq} / \mathrm{g} \\
\mathrm{LUNG})\end{array}$ & DPE & $\begin{array}{l}30 \text {-DAY } \\
\text { GRAYS }\end{array}$ & $\begin{array}{l}900-D A Y \\
\text { GRAYS }\end{array}$ & $\begin{array}{l}\text { GRAYS AT } \\
\text { DEATH }\end{array}$ & MODE & OF DEATH & $\begin{array}{l}\text { AAJOR } \\
\text { FINDING }\end{array}$ \\
\hline 248 & 3230 & M & MORTALITY & 224 & 0 & 830 & 0 & 0 & 0 & & ED & \\
\hline 258 & 3230 & $\mathrm{~F}$ & MORTALITY & 121 & 0 & 790 & 0 & 0 & 0 & & İHANIZED & \\
\hline 263 & 3230 & $\mathrm{~F}$ & MORTALITY & 104 & 0 & 988 & 0 & 0 & 0 & DIE & ED & \\
\hline 264 & $\begin{array}{l}3230 \\
3230\end{array}$ & F & MORTALITY & 113 & $0_{0}^{0}$ & 870 & 0 & 0 & 0 & EUT & THANIZED & \\
\hline 269 & $\begin{array}{l}\begin{array}{l}3230 \\
3230\end{array} \\
3230\end{array}$ & $\mathrm{~F}$ & $\begin{array}{l}\text { MORTALIIY } \\
\text { MORTALITY }\end{array}$ & $\begin{array}{l}126 \\
114\end{array}$ & $\begin{array}{l}0 \\
0 \\
0\end{array}$ & $\begin{array}{l}790 \\
982\end{array}$ & $\begin{array}{l}0 \\
0\end{array}$ & $\begin{array}{l}0 \\
0\end{array}$ & $\begin{array}{l}0 \\
0 \\
0\end{array}$ & $\begin{array}{l}\text { EUT } \\
\text { EUT }\end{array}$ & $\begin{array}{l}\text { THANIZED } \\
\text { THAN IZED }\end{array}$ & \\
\hline 275 & $\begin{array}{l}3230 \\
3230\end{array}$ & $\mathrm{~F}$ & MORTALITY & $\begin{array}{l}114 \\
131\end{array}$ & 0 & $\begin{array}{l}982 \\
852\end{array}$ & 0 & 0 & 0 & EUT & $\begin{array}{l}\text { THANIZED } \\
\text { HANE }\end{array}$ & \\
\hline 281 & 3230 & M & MORTALITY & 236 & 0 & 231 & 0 & 0 & 0 & DIE & EO & PNEUMONIA \\
\hline 285 & 3230 & M & MORTALI I Y & 214 & 0 & 838 & 0 & 0 & 0 & DIE & & \\
\hline 291 & 3230 & M & MORTALITY & 249 & 0 & 743 & 0 & 0 & 0 & EUT & THANIZED & \\
\hline 299 & $\begin{array}{l}3230 \\
3230\end{array}$ & M & MORTALI ITY & 249 & 0 & 832 & 0 & 0 & 0 & EUTं & HANIZED & \\
\hline $\begin{array}{l}301 \\
302\end{array}$ & $\begin{array}{l}3230 \\
3230\end{array}$ & $M$ & $\begin{array}{l}\text { MORTAL ITY } \\
\text { MORTIT }\end{array}$ & $\begin{array}{l}256 \\
257\end{array}$ & $\begin{array}{l}0 \\
0 \\
0\end{array}$ & 638 & 0 & $\begin{array}{l}0 \\
0\end{array}$ & $\begin{array}{l}0 \\
0\end{array}$ & DIE & ED & \\
\hline $\begin{array}{l}302 \\
309\end{array}$ & $\begin{array}{l}3230 \\
3230\end{array}$ & $M$ & $\begin{array}{l}\text { MORTALITY } \\
\text { MORTALITY }\end{array}$ & $\begin{array}{l}257 \\
210\end{array}$ & $\begin{array}{l}0 \\
0\end{array}$ & $\begin{array}{l}760 \\
870\end{array}$ & $\begin{array}{l}0 \\
0\end{array}$ & $\begin{array}{l}0 \\
0 \\
0\end{array}$ & $\begin{array}{l}0 \\
0\end{array}$ & $\begin{array}{l}\text { EIE } \\
\text { EUT }\end{array}$ & ED & \\
\hline 337 & 3230 & $\mathrm{~F}$ & $\begin{array}{l}\text { MOR TAL I IY } \\
\text { TST }\end{array}$ & 113 & 70 & 783 & 1 & 4 & 4 & EUT & THANIZED & \\
\hline $\begin{array}{l}368 \\
246\end{array}$ & $\begin{array}{l}3230 \\
3230\end{array}$ & $F$ & MORTAL ITY & 129 & 90 & 848 & 1 & ${ }_{10}^{5}$ & 5 & DIE & ED & \\
\hline $\begin{array}{l}246 \\
255\end{array}$ & $\begin{array}{l}3230 \\
3230\end{array}$ & $\begin{array}{l}M \\
F\end{array}$ & $\begin{array}{l}\text { MORRALITY } \\
\text { MORTALITY }\end{array}$ & $\begin{array}{l}245 \\
114\end{array}$ & $\begin{array}{l}100 \\
100\end{array}$ & $\begin{array}{l}921 \\
789\end{array}$ & $\frac{1}{1}$ & $\begin{array}{l}10 \\
10\end{array}$ & $\begin{array}{r}10 \\
5\end{array}$ & EUT & $\begin{array}{l}\text { THANIZED } \\
\text { THANIZED }\end{array}$ & \\
\hline $\begin{array}{l}253 \\
190\end{array}$ & 3230 & M & MORTALITY & 194 & 100 & 758 & 1 & 10 & $\begin{array}{c}5 \\
10\end{array}$ & $\begin{array}{l}\text { EUI } \\
D I E\end{array}$ & ED & \\
\hline 249 & 3230 & $M$ & MORTALITY & 179 & 110 & 802 & 1 & & 10 & & THANIZED & \\
\hline 214 & 3230 & $F$ & MORTALITY & 125 & 110 & & 1 & 10 & 10 & & THANIZED & \\
\hline 349 & 3230 & M & MORTALITY & 204 & 140 & 649 & 2 & 10 & 10 & DIE & & \\
\hline 115 & 3230 & M & MORTALITY & 259 & 170 & 679 & 2 & 10 & 10 & EUT & IHANIZED & \\
\hline 253 & $\begin{array}{l}3230 \\
3230\end{array}$ & $\mathrm{~F}$ & MORTAL I TY & 120 & $\begin{array}{l}180 \\
230\end{array}$ & 832 & $\begin{array}{l}2 \\
3\end{array}$ & 10 & 10 & DIE & ED & \\
\hline $\begin{array}{l}124 \\
335\end{array}$ & $\begin{array}{l}3230 \\
3230\end{array}$ & $\mathrm{M}_{\mathrm{F}}^{\mathrm{M}}$ & $\begin{array}{l}\text { MORTALL ITY } \\
\text { MORTALITY }\end{array}$ & $\begin{array}{r}227 \\
94\end{array}$ & $\begin{array}{l}230 \\
290\end{array}$ & $\begin{array}{l}941 \\
881\end{array}$ & $\begin{array}{l}3 \\
3\end{array}$ & $\begin{array}{l}10 \\
20\end{array}$ & 10 & $\begin{array}{l}\text { DIE } \\
\text { FUT }\end{array}$ & $\begin{array}{l}\text { ED } \\
\text { THANIZED }\end{array}$ & \\
\hline $\begin{array}{l}335 \\
265\end{array}$ & $\begin{array}{l}3230 \\
3230\end{array}$ & $\mathrm{~F}$ & MORTALITY & $\begin{array}{l}94 \\
97\end{array}$ & $\begin{array}{l}290 \\
300\end{array}$ & $\begin{array}{l}881 \\
716\end{array}$ & $\begin{array}{l}3 \\
3\end{array}$ & $\begin{array}{l}20 \\
20\end{array}$ & $\begin{array}{l}10 \\
10\end{array}$ & $\begin{array}{l}E \cup T \\
D I E\end{array}$ & $\begin{array}{l}\text { THANIZED } \\
\text { ED }\end{array}$ & \\
\hline $\begin{array}{l}265 \\
358\end{array}$ & 3230 & $\mathrm{~F}$ & MORTALITY & 126 & 520 & $\begin{array}{l}110 \\
865\end{array}$ & $\begin{array}{l}3 \\
6\end{array}$ & 30 & 30 & $\begin{array}{l}\text { DIE } \\
\text { DIE }\end{array}$ & ED & \\
\hline 331 & 3230 & $\mathrm{~F}$ & MORTAL ITY & 104 & 600 & 1028 & 7 & 30 & 30 & & RESOLVED & \\
\hline 167 & 3230 & M & MORTALITY & 196 & 780 & 467 & 9 & 40 & 40 & DIE & & ALVEOLAR_HISTEO \\
\hline 323 & 3230 & $\mathrm{~F}$ & MOR TAL I TY & 105 & 860 & 603 & 10 & 50 & 40 & EUT & THANIZED & \\
\hline $\begin{array}{l}356 \\
200\end{array}$ & 3230 & $\mathrm{~F}$ & MORTALITY & 110 & 860 & 733 & 10 & 50 & 40 & EUT & THANIZED & \\
\hline $\begin{array}{l}228 \\
314\end{array}$ & $\begin{array}{l}3230 \\
3230\end{array}$ & $\begin{array}{c}M \\
F\end{array}$ & $\begin{array}{l}\text { MORTALITY } \\
\text { MORTALIYY }\end{array}$ & $\begin{array}{l}190 \\
127\end{array}$ & $\begin{array}{l}900 \\
920\end{array}$ & $\begin{array}{l}686 \\
538\end{array}$ & 11 & $\begin{array}{l}50 \\
50\end{array}$ & $\begin{array}{l}50 \\
50\end{array}$ & $\begin{array}{l}\text { DIE } \\
\text { DIE }\end{array}$ & $E D$ & NO LESIONS \\
\hline 274 & $\begin{array}{l}3230 \\
3230\end{array}$ & F & MORTALITY & 117 & $\begin{array}{l}920 \\
980\end{array}$ & $\begin{array}{l}538 \\
749\end{array}$ & 12 & $\begin{array}{l}50 \\
50\end{array}$ & 50 & & $\begin{array}{l}E U \\
E D\end{array}$ & NO_LESIONS \\
\hline 247 & 3230 & M & MORTALITY & 246 & 1040 & 727 & 12 & 50 & 60 & DIE & $E D$ & \\
\hline 362 & 3230 & $\mathrm{~F}$ & MORTALITY & 111 & 1050 & 876 & 12 & 60 & 50 & & $E D$ & \\
\hline 199 & 3230 & $\mathrm{~F}$ & MORTALITY & 127 & 1050 & 692 & 12 & 60 & 50 & & $E D$ & \\
\hline 330 & 3230 & $F$ & MORTALITY & 94 & 1080 & 818 & 13 & 60 & 50 & $D_{1}^{\prime} E$ & & \\
\hline 163 & 3230 & $M$ & MORTALITY & 209 & 1080 & 876 & 13 & 60 & 60 & EUT & THANIZED & \\
\hline $\begin{array}{l}344 \\
364\end{array}$ & $\begin{array}{l}3230 \\
3230\end{array}$ & $\mathrm{~F}_{\mathrm{F}}^{\mathrm{M}} \mathrm{C}-\mathrm{C}$ & $\begin{array}{l}\text { MORRAALITY } \\
\text { MORTALITY }\end{array}$ & $\begin{array}{l}211 \\
122\end{array}$ & $\begin{array}{l}1150 \\
1230\end{array}$ & $\begin{array}{l}932 \\
881\end{array}$ & $\begin{array}{l}14 \\
14\end{array}$ & $\begin{array}{l}60 \\
60\end{array}$ & $\begin{array}{l}60 \\
60\end{array}$ & $\begin{array}{l}\text { EUT } \\
\text { EUT }\end{array}$ & $\begin{array}{l}\text { THANIZED } \\
\text { THANIZED }\end{array}$ & \\
\hline $\begin{array}{l}304 \\
220\end{array}$ & $\begin{array}{l}3230 \\
3230\end{array}$ & $F$ & MORTALITY & $\begin{array}{l}122 \\
106\end{array}$ & 1250 & $\begin{array}{l}881 \\
786\end{array}$ & $\begin{array}{l}14 \\
15\end{array}$ & $\begin{array}{l}60 \\
70\end{array}$ & $\begin{array}{l}60 \\
60\end{array}$ & 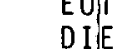 & IED & \\
\hline $\begin{array}{l}220 \\
243\end{array}$ & $\begin{array}{l}3230 \\
3230\end{array}$ & M & MORTALITY & 218 & 1270 & $\begin{array}{l}786 \\
901\end{array}$ & 15 & 70 & 70 & & ED & \\
\hline 210 & 3230 & $\mathrm{~F}$ & MORTALITY & 120 & 1320 & 538 & 16 & 70 & 60 & & $\begin{array}{llll} & \\
E D & & & \\
E\end{array}$ & LEUKEMIA \\
\hline 227 & 3230 & M & MORTALITY & 197 & 1320 & 805 & 16 & 70 & 70 & Dile & ED & \\
\hline 279 & 3230 & $F$ & MORTAL ITY & 117 & 1350 & 812 & 16 & 70 & 70 & DIIE & & \\
\hline 174 & $\begin{array}{l}3230 \\
2230\end{array}$ & $M$ & MORTAL ITY & 212 & 1400 & 901 & 16 & 70 & 70 & & THAN IZED & \\
\hline 143 & $\begin{array}{l}3230 \\
3230\end{array}$ & F & MORTALITY & 1112 & $\begin{array}{l}1420 \\
1430\end{array}$ & $\begin{array}{l}791 \\
626\end{array}$ & 17 & $\begin{array}{l}10 \\
80\end{array}$ & 70 & & ED & \\
\hline
\end{tabular}




\begin{tabular}{c} 
ANIMAL \\
NUMBER \\
\hline 238 \\
\hline 238 \\
169 \\
118 \\
352 \\
131 \\
326 \\
126 \\
128 \\
223 \\
185 \\
103 \\
164 \\
250 \\
321 \\
101 \\
156 \\
225 \\
180 \\
319 \\
234 \\
259 \\
158 \\
176 \\
211 \\
194 \\
178 \\
345 \\
133 \\
303 \\
361 \\
287 \\
219 \\
184 \\
232 \\
307 \\
359 \\
318 \\
112 \\
230 \\
130 \\
209 \\
129 \\
284 \\
114 \\
365 \\
273 \\
311 \\
117 \\
229 \\
121 \\
\hline
\end{tabular}

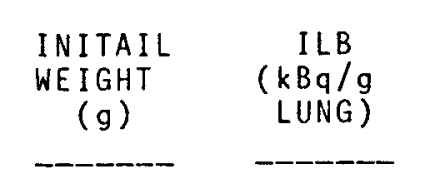

\begin{tabular}{ll} 
GROUP & $(\mathrm{g})$ \\
\hline
\end{tabular}

MORTALITY
MORTALITY
MORTALITY

MORTALITY

MORTALITY

MORTALITY
MORTALIIYY
MORTIIY

MORTALITY

MORTALITY
MORTALITY
MORTALITY

MORTALITY

MORALITY
MORTALITY
MORTALITY
MORTALITY

MORTALLITY
MORTALITY
MORTALITY

MORALLTY
MORTALITY
MORTALITY

MORTALITY
MORTALITY
MOTALITY

MORTALITY

MORTALITY

MORTALLITY
MORTALITY

MORALLITY
MORTALITY
MRTALITY

MORTALIY
MORTALITY

MORALLTY
MORTALITY
MOTALTY

MORAALITY
MORTALITY

MORTALITY

MORAALTY
MORTALITY
MOTSALTY

MORTALIYY
MORTALITY

MORTALIYY
MORTALITY
MOTA

MORTALITY

MORTALITY
MORTAITY

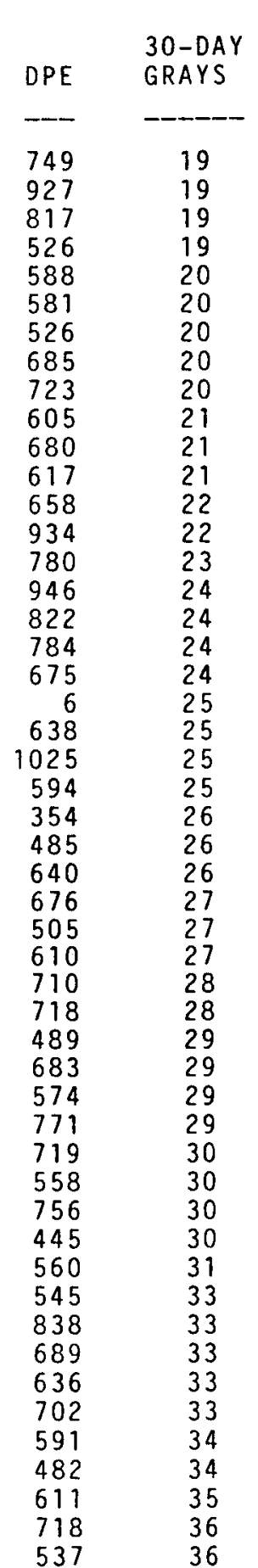

\begin{tabular}{c}
$900-D A Y$ \\
GRAYS \\
\hdashline-90 \\
80 \\
80 \\
80 \\
90 \\
90 \\
90 \\
90 \\
90 \\
90 \\
90 \\
90 \\
100 \\
100 \\
100 \\
100 \\
110 \\
110 \\
110 \\
110 \\
110 \\
110 \\
110 \\
110 \\
120 \\
120 \\
120 \\
120 \\
120 \\
120 \\
120 \\
130 \\
130 \\
130 \\
130 \\
130 \\
130 \\
130 \\
140 \\
140 \\
140 \\
150 \\
150 \\
150 \\
150 \\
150 \\
150 \\
150 \\
160 \\
160 \\
160 \\
\end{tabular}

MAJOR
FINDING

Euthanized

EUTHA
DIED
DIED

EUTHANIZEO
OIED
IED

DIED
DIED

EUTHANIZED
EUTANIZEO
EITEB

DIED
DIED
DIED

DIED
DIED
DIED

列

DIE
DIED

EUTHANIZEO
DIED

DIED
DIED

DIED
DIED
DIED
DIED

DIED
DIED
DIED
DIED
DIED

D
DIED
OIED
OIED
DIED
DIED

DIED
EUTHANIZED

DIED
OIED

U UTHANIZED

DIED
DIED
DIED

OIED

DIED

0
01 E

\begin{tabular}{l} 
DIED \\
OIED \\
$D I E D$ \\
\hline
\end{tabular}

DIED
DIED
DIED
DIED

SQUAM_CELL_CA

SQUAM_CELL_CA

CONGESTION

LEUKEMIA

NO_LESIONS

SQUAM_CELL_CA
RAD_PNEUMONITIS

RAD_PNEUMONITIS

PULMONARY THROMBOSIS
HEMANG IOSARCOMA

ALVEOLAR_HISTEO

HEMANG IOSARCOMA

RAD_PNEUMONITIS

alveOLAR_hISTEO
OTHER FINOINGS AT DEATH

SQUAM_CELL_CA, SEPT_FIBROSIS

RAD_PNEUMONITIS, SEPT_FIBROSIS

SEPT_FIBROSIS, HEMORRHAGE 
10. PATHOLOGICAL OBSERVATIONS AND OTHER COMMENTS FOR RATS THAT DIED, WERE SACRIFICED OR EUTHANIZED AFTER INHALATION EXPOSURE TO PM 147 -FAP

\begin{tabular}{|c|c|c|c|c|c|c|c|c|c|c|}
\hline $\begin{array}{l}\text { ANIMAL } \\
\text { NUMBR }\end{array}$ & $\begin{array}{l}\text { EXPERT- } \\
\text { MENT } \\
\text { NUMBER }\end{array}$ & SEX & GROUP & $\begin{array}{c}\text { INI IAL } \\
\text { WEIGHT } \\
(g)\end{array}$ & 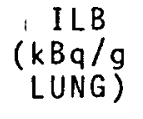 & DPE & $\begin{array}{l}\text { Go-DYY } \\
\text { GRAYS }\end{array}$ & $\begin{array}{l}900-D A Y \\
\text { GRAYS }\end{array}$ & $\begin{array}{l}\text { GRAAS AT } \\
\text { DEATH }\end{array}$ & MODE OF DEATH \\
\hline 334 & & $F$ & MORTALITY & & & & & & & \\
\hline 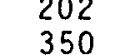 & $\begin{array}{l}\begin{array}{l}3230 \\
3230\end{array} \\
320\end{array}$ & m & $\begin{array}{l}\text { MORTALITY } \\
\text { MORTALITY }\end{array}$ & $\begin{array}{l}123 \\
223 \\
223\end{array}$ & $\begin{array}{l}33100 \\
330\end{array}$ & $\begin{array}{l}577 \\
629\end{array}$ & $\begin{array}{l}37 \\
37\end{array}$ & $\begin{array}{l}160 \\
160\end{array}$ & 150 & $\begin{array}{l}\text { DIED } \\
\text { DIE }\end{array}$ \\
\hline 144 & $\begin{array}{l}3230 \\
3230 \\
3230\end{array}$ & $F$ & MORTALITY & 130 & $\begin{array}{l}3150 \\
3150 \\
3190\end{array}$ & $\begin{array}{l}603 \\
603\end{array}$ & $\begin{array}{l}37 \\
37\end{array}$ & $\begin{array}{l}170 \\
170\end{array}$ & $\begin{array}{l}160 \\
160\end{array}$ & 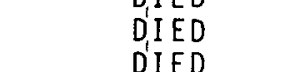 \\
\hline $\begin{array}{l}154 \\
203\end{array}$ & $\begin{array}{l}3230 \\
320\end{array}$ & F & MORTALIYY & 115 & $\begin{array}{l}3190 \\
3190\end{array}$ & $\begin{array}{l}103 \\
587 \\
582\end{array}$ & $\begin{array}{l}31 \\
38 \\
38\end{array}$ & $\begin{array}{l}110 \\
170\end{array}$ & $\begin{array}{l}160 \\
150 \\
150\end{array}$ & 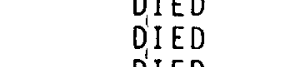 \\
\hline $\begin{array}{l}201 \\
137\end{array}$ & $\begin{array}{l}\begin{array}{l}3230 \\
3230\end{array} \\
320\end{array}$ & & $\begin{array}{l}\text { MORTALITY } \\
\text { MORTALITY }\end{array}$ & $\begin{array}{l}127 \\
136\end{array}$ & $\begin{array}{l}3190 \\
3200\end{array}$ & $\begin{array}{l}683 \\
439\end{array}$ & $\begin{array}{l}38 \\
38\end{array}$ & $\begin{array}{l}170 \\
170\end{array}$ & $\begin{array}{l}160 \\
150\end{array}$ & 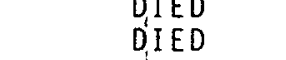 \\
\hline $\begin{array}{l}347 \\
251\end{array}$ & $\begin{array}{l}3230 \\
3230\end{array}$ & M & $\begin{array}{l}\text { MORTALITY } \\
\text { MORALIY }\end{array}$ & $\begin{array}{l}216 \\
113\end{array}$ & $\begin{array}{l}3240 \\
3240\end{array}$ & $\begin{array}{l}812 \\
606\end{array}$ & $\begin{array}{l}38 \\
38 \\
38\end{array}$ & 170 & $\begin{array}{l}170 \\
160\end{array}$ & 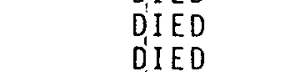 \\
\hline 171 & $\begin{array}{l}3230 \\
3230\end{array}$ & $\mathrm{M}$ & $\begin{array}{l}\text { MORTALITY } \\
\text { MORALIY }\end{array}$ & 207 & $\begin{array}{l}3260 \\
3280\end{array}$ & $\begin{array}{l}656 \\
556\end{array}$ & $\begin{array}{l}38 \\
32\end{array}$ & 170 & 170 & 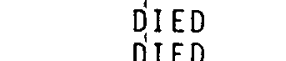 \\
\hline & 3230 & & MORTALITY & 137 & 3310 & 371 & 39 & 170 & 150 & 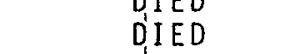 \\
\hline $\begin{array}{l}175 \\
293\end{array}$ & $\begin{array}{l}3230 \\
3230\end{array}$ & $\stackrel{M}{M}$ & $\begin{array}{l}\text { MORTALIIY } \\
\text { MORTALITY }\end{array}$ & $\begin{array}{l}228 \\
226\end{array}$ & $\begin{array}{l}3520 \\
3840\end{array}$ & $\begin{array}{l}558 \\
545\end{array}$ & $\begin{array}{l}41 \\
45\end{array}$ & $\begin{array}{l}190 \\
200\end{array}$ & $\begin{array}{l}180 \\
200\end{array}$ & 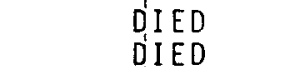 \\
\hline 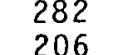 & $\begin{array}{l}3230 \\
32300\end{array}$ & $M$ & $\begin{array}{l}\text { MORALLITYY } \\
\text { MORTLITY }\end{array}$ & $\begin{array}{l}213 \\
142\end{array}$ & $\begin{array}{l}3890 \\
3890\end{array}$ & $\begin{array}{l}569 \\
548\end{array}$ & 年6 & 年 210 & 200 & DIED \\
\hline 146 & $\begin{array}{l}3230 \\
3220\end{array}$ & $\mathrm{~F}$ & MORALITY & $\begin{array}{l}134 \\
134 \\
210\end{array}$ & $\begin{array}{l}4320 \\
4320\end{array}$ & $\begin{array}{l}490 \\
690\end{array}$ & $\begin{array}{l}41 \\
51 \\
51\end{array}$ & 230 & 210 & DIED \\
\hline 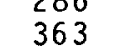 & 3230 & r & MORTALITY & $\begin{array}{l}219 \\
105\end{array}$ & $\begin{array}{l}4360 \\
4370\end{array}$ & $\begin{array}{l}646 \\
646\end{array}$ & 51 & 230 & 210 & 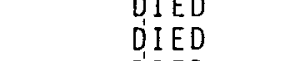 \\
\hline $\begin{array}{l}353 \\
110\end{array}$ & $\begin{array}{l}\begin{array}{l}3230 \\
3230\end{array} \\
323\end{array}$ & ${ }_{M}^{M}$ & $\begin{array}{l}\text { MORTALITY } \\
\text { MORTALIYY }\end{array}$ & $\begin{array}{l}208 \\
265 \\
265\end{array}$ & $\begin{array}{l}4410 \\
4420\end{array}$ & $\begin{array}{l}355 \\
416\end{array}$ & $\begin{array}{l}52 \\
52\end{array}$ & $\begin{array}{l}230 \\
230\end{array}$ & $\begin{array}{l}200 \\
220\end{array}$ & $\begin{array}{l}\text { DifED } \\
\text { DIIED }\end{array}$ \\
\hline $\begin{array}{l}300 \\
134 \\
134\end{array}$ & 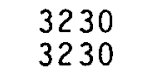 & $\underset{F}{M}$ & $\begin{array}{l}\text { MORTALIIY } \\
\text { MORTALITY }\end{array}$ & $\begin{array}{l}239 \\
134\end{array}$ & $\begin{array}{l}4520 \\
4730\end{array}$ & $\begin{array}{l}520 \\
534\end{array}$ & $\begin{array}{l}53 \\
56\end{array}$ & $\begin{array}{l}240 \\
250\end{array}$ & $\begin{array}{l}230 \\
230\end{array}$ & 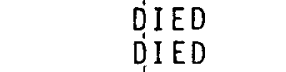 \\
\hline 193 & $\begin{array}{l}3230 \\
3230\end{array}$ & & $\begin{array}{l}\text { OORTALITY } \\
\text { MORTLITY }\end{array}$ & $\begin{array}{l}130 \\
142\end{array}$ & $\begin{array}{l}5210 \\
5310\end{array}$ & $\begin{array}{l}494 \\
553\end{array}$ & $\begin{array}{l}61 \\
62 \\
62\end{array}$ & $\begin{array}{l}270 \\
2780\end{array}$ & $\begin{array}{l}250 \\
270 \\
270\end{array}$ & $\begin{array}{l}\text { DIED } \\
\text { DIED }\end{array}$ \\
\hline & $\begin{array}{l}3230 \\
3220\end{array}$ & F & MORTALITY & 131 & $\begin{array}{l}5450 \\
5450\end{array}$ & 312 & 64 & 290 & 230 & DIED \\
\hline 192 & 3230 & $\mathrm{~F}$ & MORTALIYY & 135 & $\begin{array}{l}5800 \\
5860\end{array}$ & 513 & 69 & 310 & 290 & 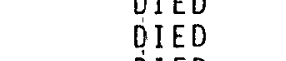 \\
\hline $\begin{array}{l}292 \\
304 \\
304\end{array}$ & $\begin{array}{l}3230 \\
3230\end{array}$ & $\underset{M}{M}$ & $\begin{array}{l}\text { MORTALITY } \\
\text { MORTALITY }\end{array}$ & $\begin{array}{l}223 \\
239\end{array}$ & $\begin{array}{l}6250 \\
6290\end{array}$ & $\begin{array}{l}556 \\
487\end{array}$ & $\begin{array}{l}74 \\
74\end{array}$ & $\begin{array}{l}330 \\
330\end{array}$ & $\begin{array}{l}320 \\
320\end{array}$ & $\begin{array}{l}D \text { DIED } \\
\text { DIED }\end{array}$ \\
\hline & 列30 & & MORTALITY & 130 & 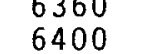 & 年 & $\begin{array}{l}15 \\
75\end{array}$ & $\begin{array}{l}340 \\
340\end{array}$ & $\begin{array}{l}3.50 \\
300\end{array}$ & $\begin{array}{l}D I E D \\
D I E D \\
D\end{array}$ \\
\hline 324 & 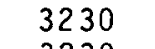 & & MORTALITY & 118 & 6570 & 456 & 77 & 350 & 300 & $\begin{array}{l}\text { DIED } \\
D E E\end{array}$ \\
\hline $\begin{array}{l}102 \\
132 \\
\end{array}$ & $\begin{array}{l}3230 \\
3230\end{array}$ & $\begin{array}{l}M \\
F\end{array}$ & $\begin{array}{l}\text { MORTALIV } \\
\text { MORTALITY }\end{array}$ & $\begin{array}{l}319 \\
130\end{array}$ & $\begin{array}{l}6160 \\
6810\end{array}$ & $\begin{array}{l}423 \\
574\end{array}$ & 80 & $\begin{array}{l}360 \\
360\end{array}$ & $\begin{array}{l}360 \\
340\end{array}$ & $\begin{array}{l}\text { DIED } \\
\text { DIED }\end{array}$ \\
\hline 315 & $\begin{array}{l}3230 \\
3230\end{array}$ & $\underset{F}{M}$ & $\begin{array}{l}\text { MORTALITY } \\
\text { MORTALITY }\end{array}$ & $\begin{array}{l}254 \\
146\end{array}$ & $\begin{array}{l}7060 \\
7080 \\
7080\end{array}$ & $\begin{array}{l}322 \\
400\end{array}$ & $\begin{array}{l}83 \\
83\end{array}$ & $\begin{array}{l}370 \\
370\end{array}$ & $\begin{array}{l}330 \\
340\end{array}$ & $\begin{array}{l}\text { D. } \\
\text { DIED }\end{array}$ \\
\hline & 3230 & F & $\begin{array}{l}\text { MORTALITY } \\
\text { MORTALITY }\end{array}$ & $\begin{array}{l}121 \\
282\end{array}$ & $\begin{array}{l}7220 \\
7250\end{array}$ & $\begin{array}{l}375 \\
339 \\
\end{array}$ & $\begin{array}{l}85 \\
85\end{array}$ & $\begin{array}{l}380 \\
380\end{array}$ & $\begin{array}{l}320 \\
350\end{array}$ & $\begin{array}{l}\text { DIED } \\
\text { DIED }\end{array}$ \\
\hline $\begin{array}{l}30 \\
12\end{array}$ & $\begin{array}{l}3230 \\
3230\end{array}$ & $M$ & $\begin{array}{l}\text { MORTALITY } \\
\text { MORALTYY }\end{array}$ & $\begin{array}{l}264 \\
240 \\
240\end{array}$ & $\begin{array}{l}7300 \\
7570\end{array}$ & $\begin{array}{l}207 \\
349\end{array}$ & $\begin{array}{l}86 \\
89 \\
89\end{array}$ & $\begin{array}{l}390 \\
400\end{array}$ & $\begin{array}{l}280 \\
350\end{array}$ & 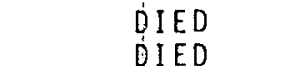 \\
\hline $\begin{array}{l}357 \\
105\end{array}$ & $\begin{array}{l}323 \\
323 \\
323\end{array}$ & $\stackrel{F}{M}$ & $\begin{array}{l}\text { MORTAL IYY } \\
\text { MORALIYY }\end{array}$ & $\begin{array}{l}128 \\
269\end{array}$ & $\begin{array}{l}7550 \\
7580\end{array}$ & $\begin{array}{l}429 \\
296\end{array}$ & $\begin{array}{l}89 \\
89\end{array}$ & $\begin{array}{l}400 \\
400\end{array}$ & $\begin{array}{l}360 \\
340\end{array}$ & $\begin{array}{l}\text { D. } \\
\text { DIED } \\
\text { DIIED }\end{array}$ \\
\hline 200 & $\begin{array}{l}3230 \\
3230\end{array}$ & $\underset{F}{F}$ & $\begin{array}{l}\text { MORTALITY } \\
\text { MORALITY }\end{array}$ & $\begin{array}{l}142 \\
121\end{array}$ & $\begin{array}{l}7600 \\
7630\end{array}$ & $\begin{array}{l}414 \\
435\end{array}$ & $\begin{array}{l}89 \\
90\end{array}$ & $\begin{array}{l}400 \\
400\end{array}$ & $\begin{array}{l}\begin{array}{l}360 \\
350\end{array} \\
350\end{array}$ & $\begin{array}{l}D I E D \\
0 I E D\end{array}$ \\
\hline 15 & 130 & & $\begin{array}{l}\text { MORTALITY } \\
\text { MORALY }\end{array}$ & 120 & 783 & $\begin{array}{l}445 \\
4371\end{array}$ & $\begin{array}{l}92 \\
92\end{array}$ & $\begin{array}{l}410 \\
410\end{array}$ & $\begin{array}{l}360 \\
360\end{array}$ & 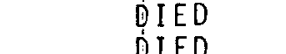 \\
\hline 160 & 230 & $\mathrm{~F}$ & MORTALITY & & 7900 & 192 & 93 & 420 & 280 & \\
\hline & 3230 & M & MORTALITY & 228 & 8050 & 259 & 95 & 420 & 330 & $D$ \\
\hline
\end{tabular}

MAJOR

HEMANG IOSARCOMA

CONGESTION HEMANGIOSARC

hemangiosarcoma

HEMANGIOSARCOMA HEMANG IOSARCOMA
HEMAGG DSACOMA
HOENG CAC CMMA

RAD_PNEUMONITIS

SQUAM_CELL_CA

HEMAGG IOSARCOMA

HEMANG IOSARCOMA

HEMANG IOSARCOMA
HEMANG IOSARCOMA

HEMANG IOSARCOMA

MEMANG OOSARCOMA
RAD PNEMONITIS

RAD-PNEUMONITIS

RAD-PNEUMONITS
RAD PNEUMONITIS

RAD PES IONS UMONIT

HEMĀNG IOSARCOMA

SQUAM CELL CA
SOUAM CELL-CA

HEMANG IOSATRCOMA

RAD_PNEUM GROSS
RAD_PNEUMONITIS
OTHER FINDINGS AT DEATH

RAD_PNEUMONITIS, SEPT_FIBROSIS

HEMORRHAGE

RAD_PNEUMONITIS, SEPT_FIBROSIS

RAD PNEUMONITIS, SEPT_FIBROSIS

RADPPEUMONITIS, SOUAM CELL CA, SEPT FIBROSIS
RADPNEUMONITIS; SEPT FIBROSIS, HEMORRHAGE RAD-PNEUMONITIS, SEPT FIBROSIS

SEPT_FIBROSIS

RAD_PNEUMONITIS, SEPT_FIBROSIS

RAD_PNEUMONITIS, SEPT_FIBROSIS
RADPNEUMONITIS, SEPT_FIBROSIS

RAD PNEUMONITIS

RAD-PNEUMONIIIS, SOUAM_CELL CA, SEPT FIBROSIS
RAD-PNEUMONITIS, SEPT_E IBROSIS, HEMORRAAGE

RA_PNEUMONIIS, SEPTFIBROSIS, HEMORRHAGE
RADPNAUMONITIS, SQUAM_CELL_CA, SEPT_FIBROSIS

HEMŌRRHAGE SEPT FIBROSIS
SEPT-FIRROSIS

SEPT FIBROSIS, HEMORRHAGE

RAD PNEUMONITIS. SQUAM CELL PAP, SEPT_FIBROSIS

RAD PNEUMONITS, SEP FBRS

RAD_PNEUMONITIS, SEPT-FIBROSIS, HEMORRHAGE

SEPT_FIBROSIS 
1E. PATHOLOGICAL OBSERVATIONS AND OTHER COMMENTS FOR RATS THAT DIED, WERE SACRIFICED OR EUTHANIZED AFTER INHALATION EXPOSURE TO PM I4T-FAP

\begin{tabular}{|c|c|c|c|c|c|c|c|c|c|c|}
\hline $\begin{array}{l}\text { ANIMAL } \\
\text { NUMBER }\end{array}$ & $\begin{array}{l}\text { EXPERI- } \\
\text { MENT } \\
\text { NUMBER }\end{array}$ & SEX & GROUP & $\begin{array}{l}\text { WNTAL } \\
\text { WEIGH } \\
(g)\end{array}$ & 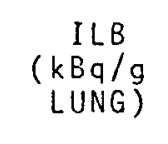 & DPE & $\begin{array}{l}30-0 . \\
\text { GRAY }\end{array}$ & $\begin{array}{l}\text { 900-DAY } \\
\text { GRAYS }\end{array}$ & $\begin{array}{l}\text { GRAAS AT } \\
\text { DEATH }\end{array}$ & MODE OF DEATH \\
\hline 152 & 32 & F & MORTALITY & 131 & 805 & 年 & 95 & 43 & 390 & DIED \\
\hline 204 & $\begin{array}{l}3230 \\
3230\end{array}$ & & $\begin{array}{l}\text { MORTALITY } \\
\text { MORTIY }\end{array}$ & $\begin{array}{l}126 \\
125\end{array}$ & $\begin{array}{l}8200 \\
8250\end{array}$ & $\begin{array}{l}299 \\
367\end{array}$ & $\begin{array}{l}96 \\
97\end{array}$ & $\begin{array}{l}430 \\
440\end{array}$ & $\begin{array}{l}350 \\
370 \\
370\end{array}$ & DIED \\
\hline & $\begin{array}{l}3230 \\
3230\end{array}$ & $m$ & $\begin{array}{l}\text { MORTALITY } \\
\text { OSRTHY }\end{array}$ & $\begin{array}{l}205 \\
277\end{array}$ & 8270 & $\begin{array}{l}234 \\
230 \\
230\end{array}$ & 97 & 440 & 320 & $\begin{array}{l}\text { DIED } \\
\text { DIED }\end{array}$ \\
\hline & & & MORTALITY & 135 & $\begin{array}{l}8320 \\
8320\end{array}$ & 381 & $\begin{array}{l}98 \\
98\end{array}$ & $\begin{array}{l}440 \\
440\end{array}$ & $\begin{array}{l}340 \\
380\end{array}$ & 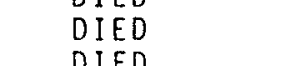 \\
\hline & & 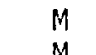 & $\begin{array}{l}\text { MOOTALITY TY } \\
\text { MRTLT }\end{array}$ & $\begin{array}{l}210 \\
210 \\
210\end{array}$ & $\begin{array}{l}8420 \\
8480\end{array}$ & $\begin{array}{l}370 \\
3707\end{array}$ & 99 & 440 & $\begin{array}{l}390 \\
320 \\
320\end{array}$ & $\begin{array}{l}\text { DED } \\
\text { DIED }\end{array}$ \\
\hline & & & MORTALITY & 129 & 8560 & 251 & 101 & $\begin{array}{l}450 \\
450\end{array}$ & 340 & $\begin{array}{l}D I E D \\
\text { OIED }\end{array}$ \\
\hline & $\begin{array}{l}32 \\
32 \\
32\end{array}$ & M & $\begin{array}{l}\text { MOOTALLTY } \\
\text { MORTALITY }\end{array}$ & $\begin{array}{l}116 \\
214\end{array}$ & $\begin{array}{l}8610 \\
8710\end{array}$ & $\begin{array}{l}407 \\
233\end{array}$ & 101 & $\begin{array}{l}450 \\
460\end{array}$ & $\begin{array}{l}390 \\
390\end{array}$ & 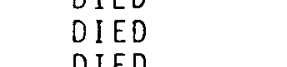 \\
\hline & & & $\begin{array}{l}\text { MORTALITY } \\
\text { MORTA ITY }\end{array}$ & 129 & 8740 & $\begin{array}{l}351 \\
432\end{array}$ & 103 & 460 & 390 & $\begin{array}{l}\text { OIED } \\
\text { DIED } \\
\text { DIE }\end{array}$ \\
\hline 208 & 3230 & F & MORTALITY & 122 & $\begin{array}{l}9210 \\
9200\end{array}$ & 368 & 108 & $\begin{array}{l}4100 \\
490\end{array}$ & $\begin{array}{l}440 \\
410\end{array}$ & $\begin{array}{l}\text { DIED } \\
\text { DIED }\end{array}$ \\
\hline & & & $\begin{array}{l}\text { MORTALTY } \\
\text { MLLT }\end{array}$ & 128 & $\begin{array}{l}9<20 \\
9340\end{array}$ & 337 & 110 & 490 & $\begin{array}{l}350 \\
410\end{array}$ & DIED \\
\hline & & & MORTALITY & 223 & 9380 & 170 & 110 & 年90 & 320 & $\begin{array}{l}\text { DIED } \\
\text { DIED }\end{array}$ \\
\hline $\begin{array}{l}360 \\
368 \\
308\end{array}$ & 3230 & $\mathrm{~F}$ & MORTALITY & 126 & 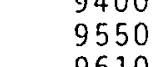 & 391 & 112 & 500 & 440 & $\begin{array}{l}\text { DIf } \\
\text { DIED } \\
\text { DIED }\end{array}$ \\
\hline 242 & 3000 & M & MORTALITY & 259 & 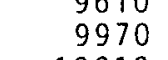 & $\begin{array}{l}240 \\
223\end{array}$ & 117 & 530 & 400 & 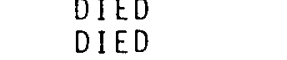 \\
\hline & & & $\begin{array}{l}\text { MOOTALITY } \\
\text { MORTALITY }\end{array}$ & & 10620 & 222 & 118 & $\begin{array}{l}530 \\
530\end{array}$ & $\begin{array}{l}360 \\
370\end{array}$ & 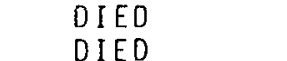 \\
\hline & 30 & $\stackrel{M}{M}$ & $\begin{array}{l}\text { MOOTALITY } \\
\text { MORTALITY }\end{array}$ & $\begin{array}{l}241 \\
217\end{array}$ & $\begin{array}{l}10050 \\
10060\end{array}$ & $\begin{array}{l}219 \\
207\end{array}$ & $\begin{array}{ll}118 \\
118\end{array}$ & $\begin{array}{l}530 \\
530\end{array}$ & $\begin{array}{l}390 \\
370\end{array}$ & $\begin{array}{l}\text { DIED } \\
\text { DIED }\end{array}$ \\
\hline $\begin{array}{l}35 \\
22 \\
V\end{array}$ & 3230 & $\stackrel{M}{M}$ & $\begin{array}{l}\text { MOOTALLITY } \\
\text { MORTALITY }\end{array}$ & $\begin{array}{l}279 \\
191 \\
191\end{array}$ & $\begin{array}{l}10230 \\
10250\end{array}$ & $\begin{array}{l}264 \\
682 \\
682 \\
\end{array}$ & $\begin{array}{l}120 \\
121\end{array}$ & $\begin{array}{l}540 \\
540\end{array}$ & $\begin{array}{l}450 \\
520\end{array}$ & 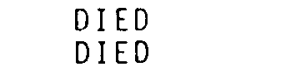 \\
\hline 283 & 30 & $M$ & $\begin{array}{l}\text { MOOTALTYY } \\
\text { MORTALITY }\end{array}$ & $\begin{array}{l}235 \\
223 \\
223\end{array}$ & $\begin{array}{l}10390 \\
10540\end{array}$ & 181 & $\begin{array}{l}122 \\
124\end{array}$ & $\begin{array}{l}560 \\
560 \\
560\end{array}$ & $\begin{array}{l}\begin{array}{l}380 \\
370\end{array} \\
370\end{array}$ & $\begin{array}{l}\text { DIED } \\
\text { DIED }\end{array}$ \\
\hline 13 & 30 & M & MORTALIYY & 198 & 10560 & $\begin{array}{l}252 \\
252 \\
276\end{array}$ & 124 & $\begin{array}{l}560 \\
5660\end{array}$ & $\begin{array}{l}480 \\
420\end{array}$ & $\begin{array}{l}\text { DIED } \\
\text { DIED } \\
\text { DIE }\end{array}$ \\
\hline 201 & & & MORTALITY & 243 & 10720 & 210 & 126 & 570 & 410 & \\
\hline & & & MORTALITY & 111 & 1180 & 198 & $\begin{array}{l}13 \\
13\end{array}$ & $\begin{array}{l}600 \\
600\end{array}$ & $\begin{array}{l}390 \\
390\end{array}$ & 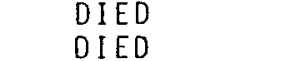 \\
\hline $\begin{array}{l}229 \\
224\end{array}$ & 30 & $\stackrel{M}{M}$ & $\begin{array}{l}\text { MORTALAIYY } \\
\text { MORTALITY }\end{array}$ & $\begin{array}{l}224 \\
196\end{array}$ & $\begin{array}{l}11470 \\
11570\end{array}$ & $\begin{array}{l}197 \\
257\end{array}$ & $\begin{array}{l}135 \\
136 \\
\end{array}$ & $\begin{array}{l}610 \\
610\end{array}$ & $\begin{array}{l}420 \\
460\end{array}$ & 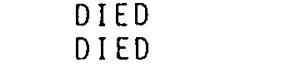 \\
\hline $\begin{array}{l}340 \\
260\end{array}$ & & & MOTALITY & 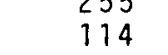 & $\begin{array}{l}116600 \\
11650\end{array}$ & $\begin{array}{l}265 \\
360 \\
\end{array}$ & $\begin{array}{l}133 \\
137\end{array}$ & $\begin{array}{l}610 \\
610\end{array}$ & 焉00 & $\begin{array}{l}\text { DIED } \\
\text { DIED }\end{array}$ \\
\hline & & & $\begin{array}{l}\text { MORTALITY } \\
\end{array}$ & 23 & 1178 & 164 & 139 & 620 & 400 & 0 \\
\hline & & & MORTALITY & 245 & $\begin{array}{l}11930 \\
1190\end{array}$ & $\begin{array}{l}160 \\
167\end{array}$ & 140 & $\begin{array}{l}630 \\
630\end{array}$ & 410 & $\begin{array}{l}\text { DIED } \\
\text { DIED }\end{array}$ \\
\hline${ }_{14}^{29}$ & 32 & F & MORTALITY & $\begin{array}{l}241 \\
123\end{array}$ & $\begin{array}{l}11930 \\
11940\end{array}$ & $\begin{array}{l}181 \\
307 \\
307\end{array}$ & $\begin{array}{l}740 \\
140\end{array}$ & $\begin{array}{l}\begin{array}{r}630 \\
630\end{array} \\
630\end{array}$ & $\begin{array}{l}300 \\
500\end{array}$ & 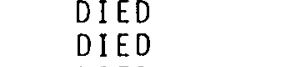 \\
\hline & & & MORTLITY & 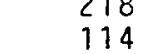 & 列2 121 & 193 & $\begin{array}{l}14 \\
14\end{array}$ & $\begin{array}{l}040 \\
640\end{array}$ & $\begin{array}{l}420 \\
420\end{array}$ & $\begin{array}{l}\text { DIED } \\
\text { DIE }\end{array}$ \\
\hline & 323 & & 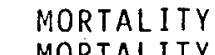 & 119 & 122 & 161 & 164 & $\begin{array}{l}650 \\
650 \\
650\end{array}$ & $\begin{array}{l}390 \\
560\end{array}$ & 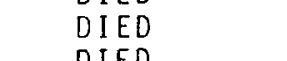 \\
\hline & & & $\begin{array}{l}\text { MOTALTY } \\
\text { MOTLTIY }\end{array}$ & 113 & $\begin{array}{l}12360 \\
12700\end{array}$ & $\begin{array}{l}199 \\
386\end{array}$ & 145 & 650 & $\begin{array}{l}430 \\
550\end{array}$ & \\
\hline
\end{tabular}

MAJOR
FINDING

RAD PNEUMONIIIS
RAD PNEMONIIS
RAD PNEUMONITIS RAD PNEUMONITIS
RAD PNEUMNITIS HEMÁNG IOSARCOMA RAD PNEUMOMITIS
RAD PNEUMONITIS RAD PNEUMONITIS RAD PNEUMONITIS HEMANGIOSARCOMA RAD PPEUONIS
RAD PNEUMONTI

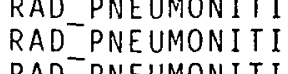
RAD PNEUMONITIS LUNG TUMOR GROSS RAD-PNEUMONITIS RAO PNE UMONITIS
RAD PNEUMONITIS RAD-PNEUMONTIS RAD_PNEUMONITI
RAD RADPPNEUMONITIS
RAD PNEUMONITIS RAD-PNEUMONIIS
RAD-PNEUMONTIS
RAS RAD-PNEUMONITIS
RADPNEUMONITIS AD-PNEUMONITIS

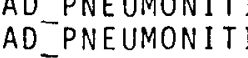

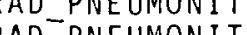
RAD- PNEUMONITIS RAD PNEUMONITIS RAD PNE UMONITS
ALVED IAR HISTE RAD PNEUMONTIS
RAD_PNEUMONITIS RAD-PNEUMONITIS RAD PMEUNONITIS
OTHER FINDINGS AT DEATH

\section{SQUAM_CELLPAP, SEPT_FIBROSIS
SEPT FIBROSIS} HEMANG IOSARCOMA

SEPT FIBROSIS
SEPT FIBROSIS

RAD ṔNEUMONITIS, SEPT_FIBROSIS, HEMORRHAGE SEP TE FIROSIS
SEPT FIBROSIS

SEPT FFIRROSS, VASCULITIS
RAD PNEUMONITS, SEPT FIBROSIS

SEPT F FIBROSIS S SEPT FIBROSIS, HEMORRHAGE
RAD PNEUMONITIS, SEP F HEMÖRRAGE SEPT F B BROSIS
SEPT- FBROSIS SEFP
SPIBT SEPT_FIBROSIS $S E P T$ FIBROSIS
$S E P T-F I B R O S I S$ SEP TIBROST SEPT FIROSIS SEPT FIBROSIS
SEPT FIBROSIS SEPT FIBROSIS
SEPT TIBROSIS SEPT FIBROSIS SEPT FIBROSIS. VASCULITIS SEPT FIBROS
SEPT FIBROSIS SEPT FIBROSIS SEPT FIBROSI
SEPT FIBROSIS

SEPTFIBROSIS, HEMORRHAGE SEPT FIBROSIS
SEPT

SEPTFIBROSIS
SEPT FIBROSI

SEPT FIBROSIS
SEPT_-FIBROSIS, VASCULITIS, SQUAM_CELL_PAP SEPT FIBROSIS

SEPT FIIROSIS
RAD PEEUMONITIS, SEPT FIBROSIS, HEMORRHAGE

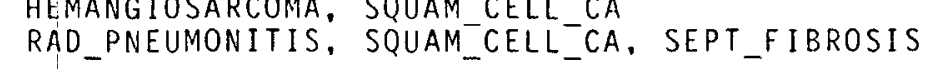


1F. PATHOLOGICAL OBSERVATIONS AND OTHER COMMENTS FOR RATS THAT DIED, WERE SACRIFICED OR EUTHANIZED AFTER INHALATION EXPOSURE TO PMI4T-FAP

\begin{tabular}{|c|c|c|c|c|c|c|c|c|c|c|}
\hline $\begin{array}{l}\text { ANIMAL } \\
\text { NUMBER }\end{array}$ & $\begin{array}{l}\text { EXPERI- } \\
\text { MENT } \\
\text { NMMBER }\end{array}$ & SEX & GROUP & $\begin{array}{l}\text { INITIAL } \\
W E \text { IGHT } \\
(g)\end{array}$ & 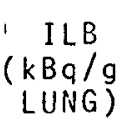 & DPE & $\begin{array}{l}30-0 A Y \\
\text { GRAYS }\end{array}$ & $\begin{array}{l}900-0 A Y \\
\text { GRAYS }\end{array}$ & $\begin{array}{l}\text { GRAYS AT } \\
\text { DEATH }\end{array}$ & MODE |OF DEATH \\
\hline $\begin{array}{l}288 \\
232\end{array}$ & $\begin{array}{l}3230 \\
3230\end{array}$ & M & MORTALITY & 2038 & $\begin{array}{l}128880 \\
2\end{array}$ & $\begin{array}{l}188 \\
181\end{array}$ & 152 & $\begin{array}{l}680 \\
7 \\
730\end{array}$ & $\begin{array}{l}450 \\
4 \\
7\end{array}$ & 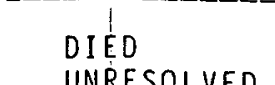 \\
\hline $\begin{array}{l}332 \\
153\end{array}$ & $\begin{array}{l}\begin{array}{l}3230 \\
3230\end{array} \\
320\end{array}$ & F & 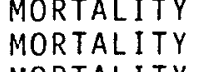 & $\begin{array}{l}98 \\
1111\end{array}$ & $\begin{array}{l}13830 \\
13850\end{array}$ & $\begin{array}{l}131 \\
343 \\
34\end{array}$ & $\begin{array}{l}163 \\
163 \\
172\end{array}$ & $\begin{array}{l}730 \\
730\end{array}$ & $\begin{array}{l}380 \\
590 \\
590\end{array}$ & $\begin{array}{l}\text { UNRRE } \\
\text { OIED } \\
\text { DIE }\end{array}$ \\
\hline $\begin{array}{l}254 \\
317 \\
316\end{array}$ & $\begin{array}{l}3230 \\
3230 \\
3\end{array}$ & F & $\begin{array}{l}\text { MORTAITY } \\
\text { MTAL TY }\end{array}$ & 109 & $\begin{array}{l}15090 \\
15590\end{array}$ & $\begin{array}{l}183 \\
197 \\
199\end{array}$ & $\begin{array}{l}177 \\
183 \\
182\end{array}$ & $\begin{array}{l}800 \\
820 \\
820\end{array}$ & $\begin{array}{l}500 \\
530 \\
5<0\end{array}$ & 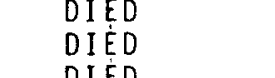 \\
\hline $\begin{array}{l}266 \\
256 \\
256\end{array}$ & $\begin{array}{l}3230 \\
3230\end{array}$ & $\mathrm{~F}$ & $\begin{array}{l}\text { MORTALITY } \\
\text { MORALITI }\end{array}$ & 102 & $\begin{array}{l}18370 \\
18450\end{array}$ & $\begin{array}{l}173 \\
189\end{array}$ & $\begin{array}{l}216 \\
217\end{array}$ & $\begin{array}{l}970 \\
970\end{array}$ & $\begin{array}{l}580 \\
630\end{array}$ & $\begin{array}{l}\text { DIED } \\
\text { DIfED }\end{array}$ \\
\hline
\end{tabular}

$\underset{\text { MAJOR }}{\text { FINDING }}$

RAD_PNEUMONITIS

RAD PNEUMONITIS

RAD-PNEUMONITIS

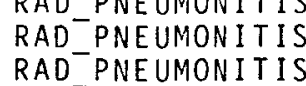

OTHER FINDINGS AT DEATH

SEPT FIBROSIS

SEPT-FIBROSIIS, VASCULITIIS, PULMONARY_THROMBOSIS SEPT-FIBROSIS
SEPT_FIBROSIS. PULMONARY_THROMBOSIS 
2A. PATHOLOGICAL OBSERVATIONS AND OTHER COMMENTS FOR RATS THAT DIED, WERE SACRIFICED OR EUTHANIZED AFTER INHALATION EXPOSURE TO SRgO-FAP

\begin{tabular}{|c|c|c|c|}
\hline $\begin{array}{l}\text { ANIMAL } \\
\text { NUMBER }\end{array}$ & $\begin{array}{l}\text { EXPERT- } \\
\text { MENT } \\
\text { NUMBER }\end{array}$ & SEX & GROUP \\
\hline 431 & 3525 & & \\
\hline 432 & 3525 & $\mathrm{~F}$ & HEMATOLOGY \\
\hline 433 & 3525 & $\mathrm{~F}$ & HEMATOL OGY \\
\hline 434 & 3525 & $\mathrm{~F}$ & HEMATOLOGY \\
\hline 435 & $\begin{array}{r}3525 \\
3525\end{array}$ & F & HEMATOLOGY \\
\hline $\begin{array}{l}436 \\
437\end{array}$ & $\begin{array}{l}3525 \\
3525\end{array}$ & $M$ & HEMATOLOGY \\
\hline $\begin{array}{l}437 \\
438\end{array}$ & $\begin{array}{l}\begin{array}{r}3525 \\
3525\end{array} \\
3525\end{array}$ & $M_{M}^{M}$ & $\begin{array}{l}\text { HEMAOLOOGY } \\
\text { HEMATOLOGY }\end{array}$ \\
\hline 439 & 3525 & M & \\
\hline 440 & 3525 & $M$ & HEMATOLOGY \\
\hline $\begin{array}{l}136 \\
340\end{array}$ & $\begin{array}{l}3522 \\
3524\end{array}$ & M & HEMATOLOGY \\
\hline $\begin{array}{l}340 \\
134\end{array}$ & $\begin{array}{l}3524 \\
3522\end{array}$ & M & HEMATOLOGY \\
\hline $\begin{array}{l}134 \\
351\end{array}$ & $\begin{array}{l}3524 \\
3524\end{array}$ & M & $\begin{array}{l}\text { HEMATOLOGY } \\
\text { HEMAOLOGY }\end{array}$ \\
\hline 339 & 3524 & M & $\begin{array}{l}\text { HEMATOLOGY } \\
\text { HEMTOLOGY }\end{array}$ \\
\hline 133 & 3522 & $\mathrm{~F}$ & HEMATOLOGY \\
\hline 332 & $\begin{array}{l}3524 \\
3524\end{array}$ & $\mathrm{~F}$ & HEMATOLOGY \\
\hline $\begin{array}{l}331 \\
335\end{array}$ & $\begin{array}{l}3524 \\
3524\end{array}$ & $\begin{array}{l}F \\
F\end{array}$ & $\begin{array}{l}\text { HEMATOLOGY } \\
\text { HEMAOLOGG }\end{array}$ \\
\hline $\begin{array}{l}335 \\
334\end{array}$ & $\begin{array}{r}\begin{array}{r}5524 \\
3524\end{array} \\
\end{array}$ & $F$ & $\begin{array}{l}\text { HEMAOLOGY } \\
\text { HEMATOLOGY }\end{array}$ \\
\hline 120 & 3522 & $\mathrm{~F}$ & $\begin{array}{l}\text { HEMATOLOGY } \\
\text { HEMTOLO }\end{array}$ \\
\hline $\begin{array}{l}234 \\
333\end{array}$ & $\begin{array}{l}3523 \\
3520\end{array}$ & F & $\begin{array}{l}\text { HEMATOLOGY } \\
\text { HEMALG }\end{array}$ \\
\hline $\begin{array}{l}\begin{array}{l}333 \\
138\end{array} \\
\end{array}$ & $\begin{array}{l}3524 \\
3522 \\
3522\end{array}$ & M & $\begin{array}{l}\text { HEMATOLOGY } \\
\text { HEMATOLOGY }\end{array}$ \\
\hline & $\begin{array}{l}3522 \\
3523\end{array}$ & $\underset{F}{M}$ & HEMATOLOGY \\
\hline 338 & $\begin{array}{l}3524 \\
3524\end{array}$ & M & $\begin{array}{l}\text { HEMATOLOGY } \\
\text { HEMAOLOGY }\end{array}$ \\
\hline 118 & 3522 & $\vec{F}$ & $\begin{array}{l}\text { HEMATTLOGY } \\
\text { HEMAOLOGY }\end{array}$ \\
\hline 119 & 3522 & $\mathrm{~F}$ & HEMATOLOGY \\
\hline 337 & 3524 & M & HEMATOLOGY \\
\hline & $\begin{array}{r}3523 \\
3552\end{array}$ & $M$ & HEMATOLOGY \\
\hline $\begin{array}{l}139 \\
232\end{array}$ & $\begin{array}{l}3522 \\
3523\end{array}$ & $\underset{F}{M}$ & $\begin{array}{l}\text { HEMAATOLOGY } \\
\text { HEMATOLOG }\end{array}$ \\
\hline 236 & 3523 & M & HEMATOL OGY \\
\hline 233 & 3523 & $\mathrm{~F}$ & HEMATOLOGY \\
\hline 239 & 3523 & M & HEMATOLOGY \\
\hline 235 & 3523 & $F$ & HEMATOLOGY \\
\hline 240 & $\begin{array}{l}3523 \\
3522\end{array}$ & $M$ & HEMATOL OGY \\
\hline $\begin{array}{l}140 \\
238\end{array}$ & $\begin{array}{l}\begin{array}{l}3522 \\
3523\end{array} \\
352\end{array}$ & $M$ & HEMATOLOGY \\
\hline 137 & 3522 & M & HEMATOLOGY \\
\hline $\begin{array}{l}401 \\
402\end{array}$ & $\begin{array}{l}3525 \\
3525\end{array}$ & F & MORTALI TY \\
\hline $\begin{array}{l}402 \\
403\end{array}$ & $\begin{array}{l}3525 \\
3525\end{array}$ & F & $\begin{array}{l}\text { MORTALITY } \\
\text { MORTAL TYY }\end{array}$ \\
\hline $\begin{array}{l}404 \\
404\end{array}$ & $\begin{array}{l}35<5 \\
3525\end{array}$ & & MOR TAL I TY \\
\hline 405 & 3525 & $\mathrm{~F}$ & MORTALITY \\
\hline 406 & 3525 & - & MORTALITY \\
\hline 407 & 3525 & $F_{F}$ & $\begin{array}{l}\text { MORTALI IY } \\
\text { MORT }\end{array}$ \\
\hline $\begin{array}{l}408 \\
409\end{array}$ & $\begin{array}{l}3525 \\
3525\end{array}$ & F & $\begin{array}{l}\text { MORTALITY } \\
\text { MORTALITY }\end{array}$ \\
\hline 410 & 3525 & $\mathrm{~F}$ & MORTALITY \\
\hline
\end{tabular}

\begin{tabular}{l} 
INITIAL \\
WEIGHT \\
$(g)$ \\
-1 \\
\hline 159 \\
176 \\
164 \\
184 \\
201 \\
268 \\
187 \\
221 \\
250 \\
252 \\
279 \\
243 \\
198 \\
273 \\
229 \\
169 \\
163 \\
153 \\
167 \\
165 \\
156 \\
169 \\
163 \\
225 \\
175 \\
234 \\
168 \\
169 \\
262 \\
212 \\
258 \\
160 \\
254 \\
170 \\
240 \\
154 \\
246 \\
224 \\
252 \\
230 \\
154 \\
147 \\
143 \\
165 \\
147 \\
147 \\
145 \\
158 \\
151 \\
157
\end{tabular}

\begin{tabular}{|c|c|c|}
\hline $\begin{array}{c}\text { ILB } \\
\left(\begin{array}{l}\mathrm{k} B \mathrm{~g} / \mathrm{g} \\
\text { UNG }\end{array}\right.\end{array}$ & DPE & $\begin{array}{l}30-\text { DAY } \\
\text { GRAYS }\end{array}$ \\
\hline 0 & 540 & 0 \\
\hline 0 & $\begin{array}{l}540 \\
540\end{array}$ & 0 \\
\hline $\begin{array}{l}0 \\
0 \\
0\end{array}$ & $\begin{array}{l}540 \\
510\end{array}$ & $\begin{array}{l}0 \\
0\end{array}$ \\
\hline 0 & 540 & 0 \\
\hline 0 & $\begin{array}{l}259 \\
540\end{array}$ & $\begin{array}{l}0 \\
0\end{array}$ \\
\hline 0 & $\begin{array}{l}540 \\
540\end{array}$ & 0 \\
\hline 0 & 480 & 0 \\
\hline $\begin{array}{r}0 \\
50\end{array}$ & $\begin{array}{l}540 \\
123\end{array}$ & $\begin{array}{l}0 \\
3\end{array}$ \\
\hline 80 & 540 & $\begin{array}{l}3 \\
6\end{array}$ \\
\hline 90 & $\begin{array}{l}565 \\
565\end{array}$ & 6 \\
\hline $\begin{array}{l}110 \\
110\end{array}$ & $\begin{array}{l}540 \\
540\end{array}$ & $\begin{array}{l}7 \\
8\end{array}$ \\
\hline 120 & $\begin{array}{l}540 \\
540\end{array}$ & $\begin{array}{l}8 \\
8\end{array}$ \\
\hline 170 & 540 & 12 \\
\hline $\begin{array}{l}170 \\
190\end{array}$ & $\begin{array}{l}540 \\
540\end{array}$ & $\begin{array}{l}12 \\
13\end{array}$ \\
\hline 210 & 540 & 14 \\
\hline 220 & 540 & 15 \\
\hline $\begin{array}{l}300 \\
310\end{array}$ & $\begin{array}{l}540 \\
540\end{array}$ & $\begin{array}{l}20 \\
21\end{array}$ \\
\hline 380 & 540 & 25 \\
\hline 500 & 540 & 34 \\
\hline $\begin{array}{l}520 \\
640\end{array}$ & $\begin{array}{l}540 \\
540\end{array}$ & $\begin{array}{l}35 \\
43\end{array}$ \\
\hline 790 & 488 & 53 \\
\hline $\begin{array}{r}790 \\
\end{array}$ & 540 & 53 \\
\hline $\begin{array}{l}1180 \\
1250\end{array}$ & $\begin{array}{l}540 \\
417\end{array}$ & $\begin{array}{r}80 \\
146\end{array}$ \\
\hline $\begin{array}{l}1270 \\
270\end{array}$ & 507 & $\begin{array}{l}86 \\
852\end{array}$ \\
\hline 1300 & $\begin{array}{l}499 \\
331\end{array}$ & $\begin{array}{l}152 \\
154\end{array}$ \\
\hline $\begin{array}{l}310 \\
1390\end{array}$ & $\begin{array}{l}431 \\
497\end{array}$ & $\begin{array}{l}154 \\
162\end{array}$ \\
\hline 1540 & 330 & 180 \\
\hline 2020 & 154 & \\
\hline $\begin{array}{l}2290 \\
2300\end{array}$ & $\begin{array}{r}99 \\
163\end{array}$ & $\begin{array}{l}268 \\
269\end{array}$ \\
\hline $\begin{array}{l}3300 \\
2510\end{array}$ & $\begin{array}{l}100 \\
163\end{array}$ & 293 \\
\hline 0 & 540 & \\
\hline $\begin{array}{l}0 \\
0\end{array}$ & $\begin{array}{l}540 \\
540\end{array}$ & $\begin{array}{l}0 \\
0\end{array}$ \\
\hline 0 & $\begin{array}{l}540 \\
540\end{array}$ & 0 \\
\hline $\begin{array}{l}0 \\
0\end{array}$ & 540 & 0 \\
\hline $\begin{array}{l}0 \\
0 \\
0\end{array}$ & $\begin{array}{l}540 \\
540\end{array}$ & $\begin{array}{l}0 \\
0\end{array}$ \\
\hline 0 & 540 & 0 \\
\hline $\begin{array}{l}0 \\
0\end{array}$ & $\begin{array}{l}540 \\
556\end{array}$ & 0 \\
\hline
\end{tabular}

GRAYS AT
DEATH

0
0
0
0
0
0
0
0
0
10
30

230

630
370
660
630
700
720
720
630
850
910
0
0
0
0
0
0
0
0
0
0
MODE OF DEATH

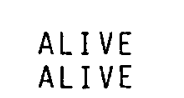

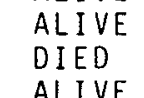

ALIVE
OIED
ALIVE
ALIVE

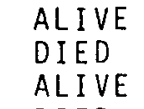

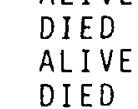

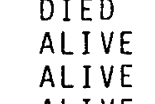

ALIVE
ALIVE
ALIVE

$\substack{\text { ALIVE } \\ \text { ALIVE }}$
A I I

ALIVE
ALIVE
Alve

ALIVE
ALIVE
ALIVE
All

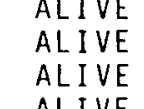

ALIVE
DIED
ALIVE
ALIVE

ALIVE
ALIVE
EUTHANIZED

EUTH
DIED
OIED

EUTHANIZE
DIED

EUTHANIZEO

DIED
DIEE
DIE

DIED
OIED
ALIVE
ALIVE

ALIVE
ALIVE
ALIVE

ALIVE
ALIVE
ALIVE

ALIVE
ALIVE
ALIVE

ALIVE
ALIVE

EUTHANIZED $\underset{\substack{\text { MAJOR } \\ \text { FINOING }}}{\ln }$

NO_LESION

NOT_SUBMITTED

NO_LESION

NO_LESION

LEUKEMIA

RAD_PNEUMONITIS

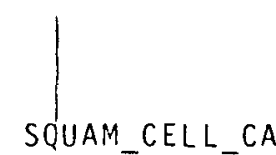

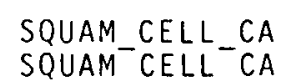

SQUAM-CEL- $C A$

SOÜA CELL CA
RAD PNEUMONITIS

RADPPNEUMONAIIS
RAD PNEUMONITIS

RAD-PNEUMONITIS

RAD-PPEEMONITIS
RAD-PNEUMONIIIS

SEPT_FIBROSIS

HEMANG IOSARCOMA

SEPT FIBROSIS, HEMANG IOSARCOMA

VASCULITIS. SEPTFFIBROSIS
VASCULITIS. SEPT_FIBROSIS

SEPT FIBROSIS
SEPT-FIBROSIS

OTHER FINDINGS AT DEATH

NOT_SUBMITTED 


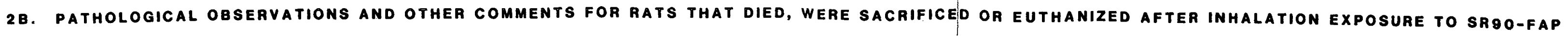

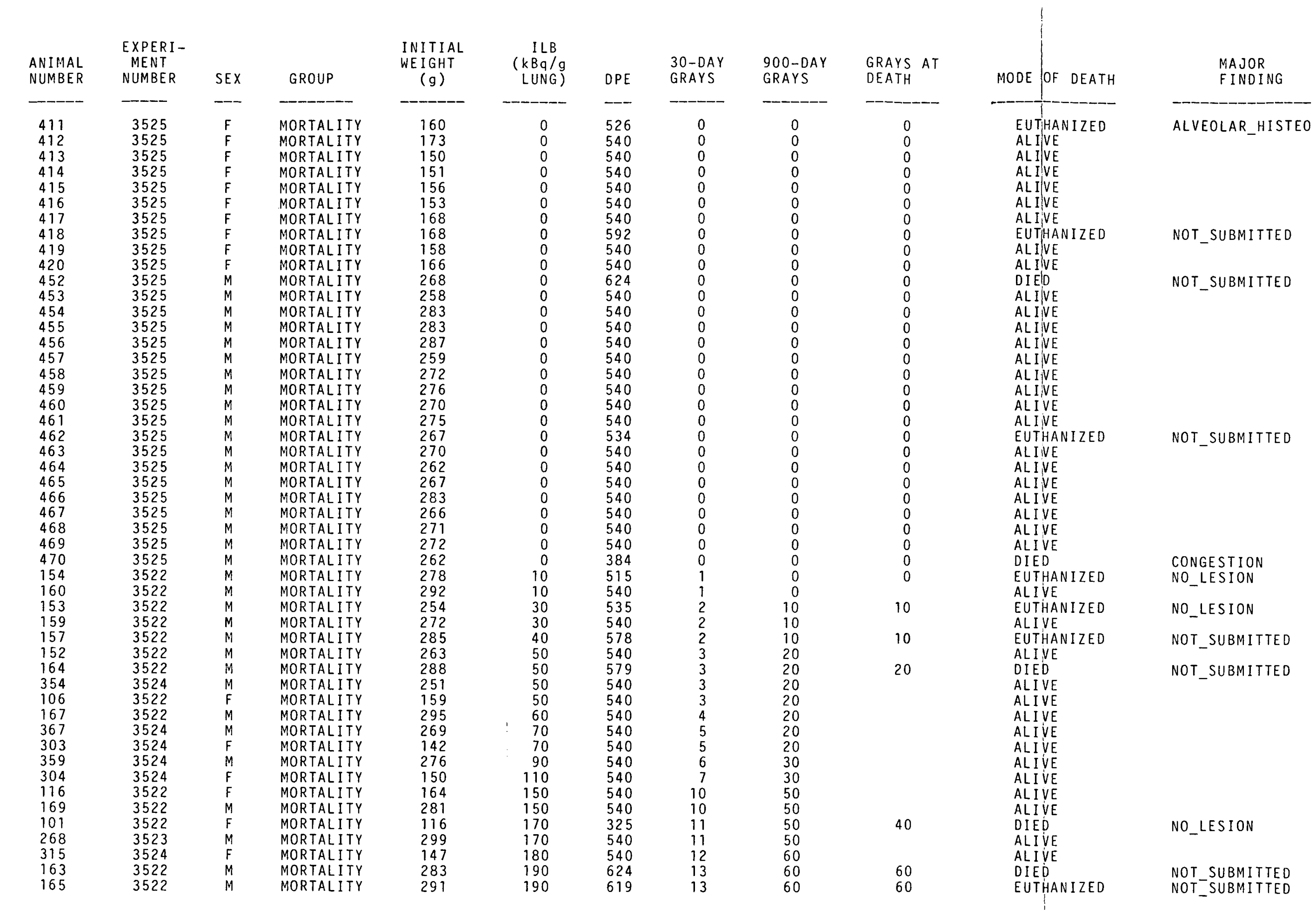


2C. PATHOLOGICAL OBSERVATIONS AND OTHER COMMENTS FOR RATS. THAT DIED, WERE SACRIFICED OR EUTHANIZED AFTER INHALATION EXPOSURE TO SRgO-FAP

\begin{tabular}{|c|c|c|c|c|}
\hline $\begin{array}{l}\text { EXPERI- } \\
\text { MENT } \\
\text { NUMBER }\end{array}$ & SEX & GROUP & $\begin{array}{c}\text { INIT IALL } \\
\text { WEIGHT } \\
(\mathrm{g})\end{array}$ & $\begin{array}{c}I L B \\
(\mathrm{kBq} / \mathrm{g} \\
\mathrm{LUNG})\end{array}$ \\
\hline & & MORTALITY & & \\
\hline 3524 & $F$ & $\begin{array}{l}\text { MORTALTY } \\
\text { MOLTY }\end{array}$ & 162 & 200 \\
\hline & $\mathrm{F}$ & MORTALITY & 156 & 200 \\
\hline 3524 & $\mathrm{~F}$ & MORTALITY & 164 & 210 \\
\hline $\begin{array}{l}3524 \\
3524\end{array}$ & M & MORTAL I TY & 279 & 230 \\
\hline $\begin{array}{l}3524 \\
3524\end{array}$ & F & MORTAL ITY & 168 & $\begin{array}{l}240 \\
250\end{array}$ \\
\hline 3524 & $F$ & MORTALITY & $\begin{array}{l}155 \\
151\end{array}$ & $\begin{array}{l}250 \\
260\end{array}$ \\
\hline 3524 & $F$ & MORTAL I TY & 174 & 260 \\
\hline $\begin{array}{l}3524 \\
3524\end{array}$ & F & MORTALITY & 160 & $\begin{array}{l}270 \\
280\end{array}$ \\
\hline 3522 & M & $\begin{array}{l}\text { MORTALITY } \\
\text { MORTALITY }\end{array}$ & $\begin{array}{l}162 \\
284\end{array}$ & $\begin{array}{l}280 \\
290\end{array}$ \\
\hline 3524 & M & MORTALITY & $\begin{array}{l}289 \\
289\end{array}$ & 290 \\
\hline $\begin{array}{l}3524 \\
3523 \\
352\end{array}$ & $M_{F}$ & MORTALITY & 287 & 310 \\
\hline 3524 & F & MORTALITY & $\begin{array}{l}151 \\
142\end{array}$ & $\begin{array}{l}310 \\
320\end{array}$ \\
\hline 3522 & M & MORTAL ITY & 282 & 320 \\
\hline $\begin{array}{l}\begin{array}{l}3523 \\
3524\end{array} \\
35\end{array}$ & $M$ & MORTALITY & 260 & $\begin{array}{l}320 \\
320\end{array}$ \\
\hline $\begin{array}{r}524 \\
3524\end{array}$ & $\stackrel{M}{M}$ & MORTALITY & 147 & $\begin{array}{l}320 \\
340\end{array}$ \\
\hline 3524 & $\mathrm{~F}$ & MORTALITY & 161 & 340 \\
\hline 3524 & $\mathrm{~F}$ & MORTALITY & 113 & $\begin{array}{l}340 \\
350\end{array}$ \\
\hline 3523 & $\mathrm{~F}$ & MORTALITY & 169 & 360 \\
\hline & $\mathrm{F}$ & MORTALITY & 164 & 380 \\
\hline $\begin{array}{l}3523 \\
3522\end{array}$ & M & MOR TAL I TY & 279 & 390 \\
\hline 35 & M & $\begin{array}{l}\text { MORTALITY } \\
\text { MORTAL }\end{array}$ & $\begin{array}{l}280 \\
274\end{array}$ & $\begin{array}{l}410 \\
420\end{array}$ \\
\hline 35 & M & MORTALITY & $\begin{array}{l}224 \\
209\end{array}$ & $\begin{array}{l}420 \\
410\end{array}$ \\
\hline 3524 & $M$ & MORTALITY & 286 & $\begin{array}{l}410 \\
430\end{array}$ \\
\hline 3523 & $F$ & MORTALITY & 153 & 440 \\
\hline 3524 & M $>>>$ & MORTALITY & 253 & 440 \\
\hline 3523 & $M$ & MORTALITY & 253 & 440 \\
\hline & F & MORTAL I TY & & 450 \\
\hline 3523 & $F$ & MORTAL ITY & $\begin{array}{l}140 \\
142\end{array}$ & $\begin{array}{l}470 \\
470\end{array}$ \\
\hline 3522 & $\mathrm{~F}$ & MORTALIY & 106 & $\begin{array}{l}470 \\
490\end{array}$ \\
\hline 3523 & M & MORTAL ITY & 283 & $\begin{array}{l}490 \\
490\end{array}$ \\
\hline 3524 & $\mathrm{~F}$ & MORTALITY & 161 & 490 \\
\hline $35 \%$ & $\mathrm{~F}$ & MORTALITY & 144 & 520 \\
\hline 35 & $M$ & MORTALITY & 300 & 550 \\
\hline 列 & s & $\begin{array}{l}\text { MORTALITY } \\
\text { MORT ITY }\end{array}$ & $\begin{array}{l}1344 \\
130\end{array}$ & 550 \\
\hline 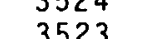 & 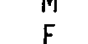 & MORTALIS & 153 & $\begin{array}{l}600 \\
610\end{array}$ \\
\hline 3522 & $\mathrm{~F}$ & MORTALITY & 154 & \\
\hline 3523 & $\mathrm{~F}$ & MORTAL TTY & 161 & 660 \\
\hline & M & MORTALITY & 270 & 690 \\
\hline 5 & $r$ & MORTALITY & 146 & 710 \\
\hline 352 & $M$ & MORTALITY & 259 & 710 \\
\hline 3524 & M & MORTALIT & $\begin{array}{l}290 \\
291\end{array}$ & $\begin{array}{l}720 \\
730\end{array}$ \\
\hline
\end{tabular}

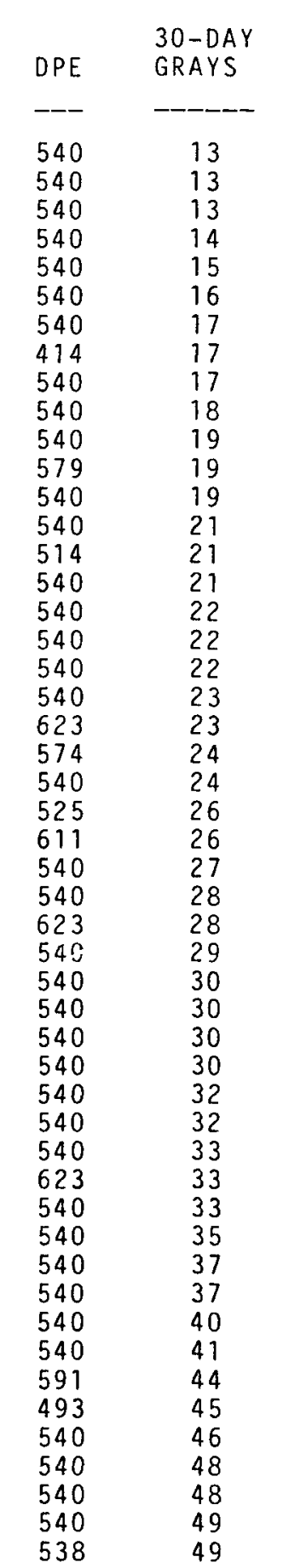

\begin{tabular}{|c|c|c|}
\hline $\begin{array}{l}900-D A Y \\
\text { GRAYS }\end{array}$ & $\begin{array}{l}\text { GRAYS AT } \\
\text { DEATH }\end{array}$ & MODE OF DEATH \\
\hline $\begin{array}{l}60 \\
60 \\
60 \\
70 \\
70 \\
80 \\
80 \\
80 \\
80 \\
90 \\
90 \\
90 \\
90 \\
90 \\
100 \\
100 \\
100 \\
100 \\
100 \\
100 \\
110 \\
110 \\
110 \\
120 \\
120 \\
130 \\
130 \\
130 \\
140 \\
140 \\
140 \\
140 \\
150 \\
150 \\
150 \\
160 \\
170 \\
170 \\
180 \\
190 \\
190 \\
200 \\
210 \\
220 \\
230 \\
230 \\
230 \\
230\end{array}$ & $\begin{array}{r}100 \\
90 \\
110 \\
120 \\
130\end{array}$ & 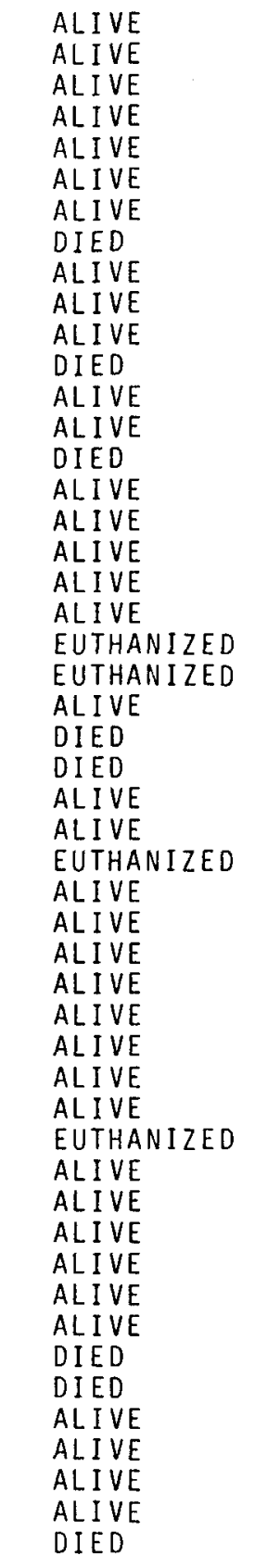 \\
\hline
\end{tabular}

$\underset{M A N O R}{\text { MAJNG }}$ FINDE

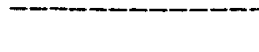

NOT_SUBMITTED

NOT_SUBMITTED

CONGESTION

NOT_SUBMITTED
NOT_SUBMITTED

CONGESTION
NOT_SUBMITTED

not_submitted

STANDARD
STANDARD

NOT_SUBMI TTED

NOT_SUBMITTED
RAD-PNEUMONITIS

LUNG_TUMOR_GROSS
OTHER FINDINGS AT DEATH 


\begin{tabular}{|c|c|c|c|c|c|c|c|c|c|c|c|}
\hline $\begin{array}{l}\text { ANIMAL } \\
\text { NUMBER }\end{array}$ & $\begin{array}{l}\text { EXPERI- } \\
\text { MERT } \\
\text { NUMBER }\end{array}$ & SEX & GROUP & $\begin{array}{c}\text { INI IAL } \\
\text { WEIGHT } \\
(\mathrm{g})\end{array}$ & 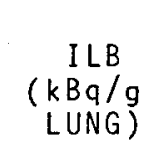 & DPE & $\begin{array}{l}30-D A Y \\
\text { GRAYS }\end{array}$ & $\begin{array}{l}900-\text { DAY } \\
\text { GRAYS }\end{array}$ & $\begin{array}{l}\text { GRAYS AT } \\
\text { DEATH }\end{array}$ & MOD'E OF DEATH & $\begin{array}{l}\text { MAJOR } \\
\text { FINDING }\end{array}$ \\
\hline $\begin{array}{l}208 \\
104 \\
266\end{array}$ & $\begin{array}{l}3523 \\
3522 \\
3523\end{array}$ & $\begin{array}{l}F \\
F \\
F\end{array}$ & $\begin{array}{l}\text { MORTALITY } \\
\text { MORTLIIYY } \\
\text { MORTATYY }\end{array}$ & $\begin{array}{l}150 \\
146 \\
283\end{array}$ & $\begin{array}{l}740 \\
760 \\
790\end{array}$ & $\begin{array}{l}540 \\
259 \\
540\end{array}$ & $\begin{array}{l}50 \\
51 \\
53\end{array}$ & $\begin{array}{l}230 \\
240 \\
250\end{array}$ & 180 & $\begin{array}{l}\text { ALIVEE } \\
\text { DLED } \\
\text { ALIVE }\end{array}$ & $\begin{array}{l}\text { STANDARD } \\
\text { NOT_SUBMITED }\end{array}$ \\
\hline $\begin{array}{l}266 \\
256 \\
217\end{array}$ & $\begin{array}{l}3523 \\
3523\end{array}$ & M & $\begin{array}{l}\text { MORTALITY } \\
\text { MORTALIY } \\
\text { OMRTAUY }\end{array}$ & $\begin{array}{l}283 \\
279 \\
156\end{array}$ & $\begin{array}{l}790 \\
810 \\
820\end{array}$ & $\begin{array}{l}540 \\
540 \\
5.0\end{array}$ & $\begin{array}{l}53 \\
55 \\
56\end{array}$ & $\begin{array}{l}250 \\
260 \\
260\end{array}$ & 250 & $\begin{array}{l}\text { ALIVE } \\
\text { ALIVE }\end{array}$ & \\
\hline $\begin{array}{l}217 \\
267 \\
262\end{array}$ & $\begin{array}{l}3523 \\
3523 \\
3523\end{array}$ & m & 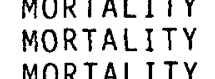 & 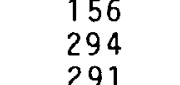 & $\begin{array}{l}830 \\
920 \\
920\end{array}$ & $\begin{array}{l}612 \\
481 \\
487\end{array}$ & $\begin{array}{l}56 \\
62 \\
62\end{array}$ & $\begin{array}{l}260 \\
290 \\
290\end{array}$ & $\begin{array}{l}250 \\
280 \\
290\end{array}$ & 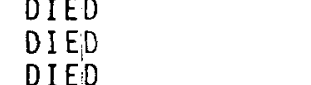 & 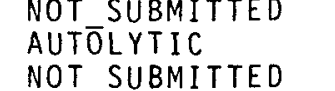 \\
\hline $\begin{array}{l}262 \\
352 \\
322\end{array}$ & $\begin{array}{l}3523 \\
3524 \\
2523\end{array}$ & M & $\begin{array}{l}\text { MORTALITY } \\
\text { MORTALIYY } \\
\text { MORTLIY }\end{array}$ & $\begin{array}{l}291 \\
267 \\
151\end{array}$ & $\begin{array}{l}930 \\
950 \\
070\end{array}$ & $\begin{array}{l}557 \\
540 \\
525\end{array}$ & $\begin{array}{l}62 \\
64 \\
665 \\
6\end{array}$ & $\begin{array}{l}290 \\
300 \\
300\end{array}$ & 290 & $\begin{array}{l}\text { DAED } \\
\text { ALINE } \\
\text { ALTE }\end{array}$ & NOT_SUBMITTED \\
\hline 269 & $\begin{array}{l}3523 \\
3522\end{array}$ & m & $\begin{array}{l}\text { MORTAITY } \\
\text { MORTLITY }\end{array}$ & $\begin{array}{l}283 \\
283 \\
284\end{array}$ & $\begin{array}{r}990 \\
970\end{array}$ & $\begin{array}{l}4<5 \\
474 \\
537\end{array}$ & $\begin{array}{l}114 \\
117\end{array}$ & 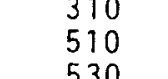 & $\begin{array}{l}270 \\
510 \\
520\end{array}$ & 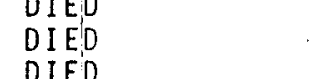 & 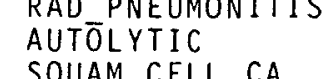 \\
\hline $\begin{array}{l}162 \\
162 \\
216\end{array}$ & $\begin{array}{l}3522 \\
3523 \\
3523\end{array}$ & ${ }_{\mathrm{F}}^{\mathrm{M}}$ & $\begin{array}{l}\text { MORTALITY } \\
\text { MORTAITY }\end{array}$ & $\begin{array}{l}287 \\
283 \\
163\end{array}$ & $\begin{array}{l}1060 \\
1060\end{array}$ & $\begin{array}{l}290 \\
378\end{array}$ & $\begin{array}{l}124 \\
71\end{array}$ & $\begin{array}{l}550 \\
530 \\
330\end{array}$ & $\begin{array}{l}530 \\
500 \\
290\end{array}$ & 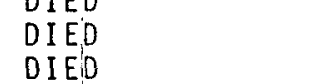 & 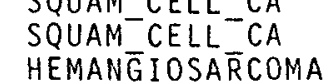 \\
\hline $\begin{array}{l}261 \\
260\end{array}$ & $\begin{array}{l}3523 \\
3523 \\
3523\end{array}$ & $\stackrel{M}{M}$ & $\begin{array}{l}\text { MORTALITY } \\
\text { MORTLIIY }\end{array}$ & $\begin{array}{l}281 \\
265\end{array}$ & $\begin{array}{l}1070 \\
1170\end{array}$ & $\begin{array}{l}540 \\
595\end{array}$ & $\begin{array}{l}125 \\
136 \\
130\end{array}$ & $\begin{array}{l}560 \\
620\end{array}$ & 610 & $\begin{array}{l}\text { ALIVE } \\
\text { EUTHANZED }\end{array}$ & NOT SUBMITTED \\
\hline $\begin{array}{l}161 \\
259\end{array}$ & $\begin{array}{l}3522 \\
3523 \\
352\end{array}$ & $\stackrel{M}{M}$ & $\begin{array}{l}\text { MORTALITY } \\
\text { MORTALITY }\end{array}$ & $\begin{array}{l}283 \\
286 \\
286\end{array}$ & $\begin{array}{l}1180 \\
1250\end{array}$ & $\begin{array}{l}586 \\
436\end{array}$ & $\begin{array}{l}138 \\
146 \\
146\end{array}$ & $\begin{array}{l}620 \\
660\end{array}$ & $\begin{array}{l}630 \\
640\end{array}$ & $\begin{array}{l}\text { DEED } \\
\text { DIED }\end{array}$ & 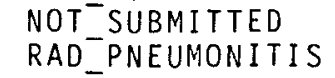 \\
\hline $\begin{array}{l}270 \\
219\end{array}$ & $\begin{array}{l}3523 \\
3523 \\
352\end{array}$ & $\begin{array}{c}M \\
F\end{array}$ & $\begin{array}{l}\text { MORTALITY } \\
\text { MORTALITY }\end{array}$ & $\begin{array}{l}311 \\
168\end{array}$ & $\begin{array}{l}1300 \\
1300\end{array}$ & $\begin{array}{l}540 \\
431\end{array}$ & $\begin{array}{l}{ }_{88}^{152} \\
88\end{array}$ & $\begin{array}{l}\begin{array}{l}690 \\
410\end{array} \\
-\end{array}$ & 400 & $\begin{array}{l}\text { AIIVE } \\
\text { DIED }\end{array}$ & RAD_PNEUMONITIS \\
\hline 13 & $\begin{array}{l}3523 \\
3523\end{array}$ & F & MORTALITY & $\begin{array}{l}150 \\
166 \\
-106\end{array}$ & $\begin{array}{l}1360 \\
1360\end{array}$ & $\begin{array}{l}383 \\
341\end{array}$ & $\begin{array}{r}91 \\
159 \\
\end{array}$ & $\begin{array}{l}430 \\
720\end{array}$ & $\begin{array}{l}360 \\
650\end{array}$ & $\begin{array}{l}\text { DIIE } \\
\text { DIEL }\end{array}$ & 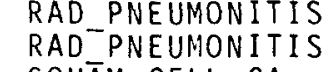 \\
\hline 151 & 3522 & & $\begin{array}{l}\text { MORTALITY } \\
\text { MORTALIYY }\end{array}$ & 260 & $\begin{array}{l}1380 \\
1410\end{array}$ & $\begin{array}{l}478 \\
354\end{array}$ & $\begin{array}{r}162 \\
95 \\
9\end{array}$ & $\begin{array}{r}300 \\
450\end{array}$ & $\begin{array}{l}100 \\
370\end{array}$ & $\begin{array}{l}\text { DIE } \\
\text { DIE }\end{array}$ & 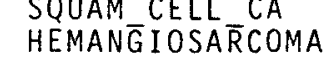 \\
\hline 205 & $\begin{array}{l}3523 \\
3523 \\
352\end{array}$ & F & $\begin{array}{l}\text { MORTALITY } \\
\text { MORTLITY }\end{array}$ & $\begin{array}{l}146 \\
272\end{array}$ & $\begin{array}{l}1430 \\
1430\end{array}$ & $\begin{array}{l}287 \\
504\end{array}$ & $\begin{array}{c}97 \\
168\end{array}$ & $\begin{array}{l}450 \\
760\end{array}$ & $\begin{array}{l}350 \\
740\end{array}$ & $\begin{array}{l}\text { DIEL } \\
\text { DEEI }\end{array}$ & $\begin{array}{l}\text { RA PADEUMON I I I } \\
\text { SOUĀA CEL CA }\end{array}$ \\
\hline $\begin{array}{l}214 \\
210 \\
210\end{array}$ & $\begin{array}{l}352 \\
352 \\
352\end{array}$ & $\mathrm{~F}$ & $\begin{array}{l}\text { MORTALITY } \\
\text { MORTLITY }\end{array}$ & 150 & $\begin{array}{l}1450 \\
1510\end{array}$ & $\begin{array}{l}442 \\
409\end{array}$ & $\begin{array}{r}98 \\
176 \\
\end{array}$ & $\begin{array}{l}460 \\
800\end{array}$ & $\begin{array}{l}440 \\
760\end{array}$ & $\begin{array}{l}\text { DIED } \\
\text { OIED }\end{array}$ & $\begin{array}{l}\text { HEMANG IOSARCDMA } \\
\text { SEPT FISROSIS }\end{array}$ \\
\hline $\begin{array}{l}265 \\
251\end{array}$ & 3503 & M & MORTALITY & 244 & $\begin{array}{l}1540 \\
1610\end{array}$ & $\begin{array}{l}534 \\
391\end{array}$ & $\begin{array}{l}180 \\
188 \\
188\end{array}$ & $\begin{array}{l}810 \\
850\end{array}$ & $\begin{array}{l}800 \\
780\end{array}$ & $\begin{array}{l}\text { DIE } \\
\text { DIE }\end{array}$ & $\begin{array}{l}\text { SOUAM CELC CA } \\
\text { RAD PNEUMONITIS }\end{array}$ \\
\hline $\begin{array}{l}109 \\
113 \\
113\end{array}$ & $\begin{array}{l}35222 \\
3522 \\
3522\end{array}$ & $F$ & $\begin{array}{l}\text { MORTALITY } \\
\text { MORTALITY }\end{array}$ & $\begin{array}{l}152 \\
152 \\
152 \\
\end{array}$ & $\begin{array}{l}1610 \\
1700\end{array}$ & $\begin{array}{l}144 \\
250\end{array}$ & $\begin{array}{l}189 \\
199 \\
199\end{array}$ & $\begin{array}{l}850 \\
900\end{array}$ & $\begin{array}{l}560 \\
740\end{array}$ & $\begin{array}{l}\text { DI } \\
01 \mathrm{E}\end{array}$ & 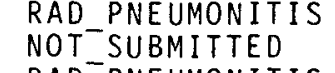 \\
\hline 02 & 3252 & & MORTALITY & 151 & 1740 & $\begin{array}{l}152 \\
326\end{array}$ & 203 & $\begin{array}{l}910 \\
920\end{array}$ & 59 & 0 & 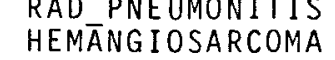 \\
\hline $\begin{array}{l}63 \\
15\end{array}$ & $\begin{array}{l}3523 \\
3\end{array}$ & $M_{F}^{M}$ & $\begin{array}{l}\text { MORTALLIY } \\
\text { MORTLITY }\end{array}$ & $\begin{array}{l}273 \\
163\end{array}$ & $\begin{array}{l}1820 \\
7830\end{array}$ & $\begin{array}{l}215 \\
157\end{array}$ & $\begin{array}{l}213 \\
214\end{array}$ & $\begin{array}{l}960 \\
970\end{array}$ & $\begin{array}{l}770 \\
670\end{array}$ & $\begin{array}{l}D I \\
D I \\
D I\end{array}$ & $\begin{array}{l}\text { RADP PNEUMONI I I } \\
\text { NOT }\end{array}$ \\
\hline 68 & 352 & $\stackrel{M}{M}$ & $\begin{array}{l}\text { MOOTALITY } \\
\text { MORTALITY }\end{array}$ & $\begin{array}{l}271 \\
301\end{array}$ & $\begin{array}{l}2060 \\
2100\end{array}$ & $\begin{array}{l}160 \\
283\end{array}$ & $\begin{array}{l}241 \\
245\end{array}$ & $\begin{array}{l}1090 \\
1110\end{array}$ & $\begin{array}{r}770 \\
1000\end{array}$ & $\begin{array}{l}\text { DI } \\
\text { DIt }\end{array}$ & 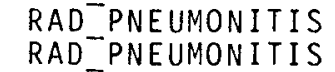 \\
\hline 166 296 & 5 & M & $\begin{array}{l}\text { MORTALITY } \\
\text { PUL_FUNCT }\end{array}$ & $\begin{array}{l}271 \\
167 \\
167\end{array}$ & $\begin{array}{c}190 \\
0\end{array}$ & $\begin{array}{l}158 \\
540\end{array}$ & $\begin{aligned} 256 \\
0\end{aligned}$ & $\begin{array}{l}1160 \\
0 \\
0\end{array}$ & $\begin{array}{l}810 \\
0 \\
0\end{array}$ & $\begin{array}{l}\text { OPED } \\
\text { ALIVE }\end{array}$ & \\
\hline 201 & 3524 & $F$ & $\begin{array}{l}\text { PUL-FUNCT } \\
\text { POL-FUCT }\end{array}$ & 151 & 0 & 540 & 0 & $\begin{array}{l}0 \\
0\end{array}$ & $\begin{array}{l}0 \\
0\end{array}$ & $\begin{array}{l}\text { ALIVE } \\
\text { ALIVE }\end{array}$ & \\
\hline 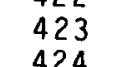 & $\begin{array}{l}3525 \\
3525 \\
3525\end{array}$ & & 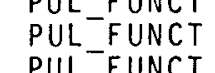 & 165 & 0 & $\begin{array}{l}520 \\
620 \\
620\end{array}$ & $\begin{array}{l}0 \\
0 \\
0\end{array}$ & $\begin{array}{l}0 \\
0 \\
0\end{array}$ & 0 & 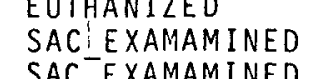 & 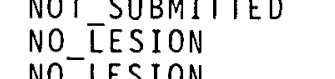 \\
\hline 2125 & $\begin{array}{l}3525 \\
3525\end{array}$ & & $\begin{array}{l}\text { PuL-FUNCT } \\
\text { PuU }\end{array}$ & $\begin{array}{l}155 \\
162 \\
\end{array}$ & $\begin{array}{l}0 \\
0 \\
0\end{array}$ & $\begin{array}{l}621 \\
621\end{array}$ & $\begin{array}{l}0 \\
0 \\
0\end{array}$ & $\begin{array}{l}0 \\
0\end{array}$ & 0 & 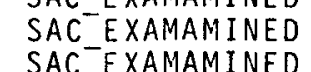 & 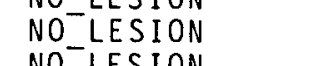 \\
\hline 2 & & & $\begin{array}{l}\text { PULFFUNCT } \\
\text { PULFUNCT }\end{array}$ & 176 & & $\begin{array}{l}622 \\
540\end{array}$ & & $\begin{array}{l}0 \\
0\end{array}$ & & $\begin{array}{l}\text { SACIEXAMA } \\
\text { ALIVE }\end{array}$ & NO_LESION \\
\hline 430 & & ${ }_{F}$ & $\begin{array}{l}\text { PULFEUCT } \\
\text { PULFUNCT }\end{array}$ & 158 & & 540 & & & & & \\
\hline
\end{tabular}


2E. PATHOLOGICAL OBSERVATIONS AND OTHER COMMENTS FOR RATS THAT DIED, WERE SACRIFICED OR EUTHANIZED AFTER INHALATION EXPOSURE TO SRgO-FAP

\begin{tabular}{|c|c|c|c|}
\hline $\begin{array}{l}\text { ANIMAL } \\
\text { NUMBER }\end{array}$ & $\begin{array}{l}\text { EXPERI- } \\
\text { MENT } \\
\text { NUMBER }\end{array}$ & SEX & GROUP \\
\hline & & & \\
\hline $\begin{array}{l}442 \\
443\end{array}$ & $\begin{array}{l}3525 \\
3525\end{array}$ & $M$ & $\begin{array}{l}\text { PUL FUNCT } \\
\text { PUL FUCI }\end{array}$ \\
\hline $\begin{array}{l}444 \\
444\end{array}$ & & $M$ & $\begin{array}{l}\text { PUL-FUNCT } \\
\text { PULA }\end{array}$ \\
\hline $\begin{array}{l}445 \\
445\end{array}$ & $\begin{array}{l}3525 \\
3525\end{array}$ & $M$ & PUL-FUNCT \\
\hline 446 & 3525 & M & PUL-FUNCT \\
\hline $\begin{array}{l}447 \\
448\end{array}$ & 3525 & M & PULF FUNCT \\
\hline $\begin{array}{l}448 \\
449\end{array}$ & $\begin{array}{r}3525 \\
3525\end{array}$ & $M$ & 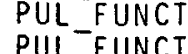 \\
\hline & $\begin{array}{l}3525 \\
3525\end{array}$ & $\begin{array}{c}M \\
M\end{array}$ & $\begin{array}{l}\text { PUL_FUCT } \\
\text { PUL FUNCT }\end{array}$ \\
\hline $\begin{array}{l}450 \\
451\end{array}$ & $\begin{array}{l}3525 \\
3525\end{array}$ & $\begin{array}{l}M \\
M\end{array}$ & $\begin{array}{l}\text { PUL-FUNCT } \\
\text { PUL FUNT }\end{array}$ \\
\hline 143 & 3522 & M & PUL FUNCT \\
\hline 347 & 3524 & M & PUL_FUNCT \\
\hline 147 & 3522 & M & PUL_FUNCT \\
\hline 125 & 3522 & $F$ & PUL_FUNCT \\
\hline $\begin{array}{l}344 \\
142\end{array}$ & $\begin{array}{l}3524 \\
3522\end{array}$ & $M_{M}^{M}$ & $\begin{array}{l}\text { PUL-FUNCT } \\
\text { PUI-FENCI }\end{array}$ \\
\hline 325 & & $\begin{array}{l}M \\
F\end{array}$ & $\begin{array}{l}\text { PUL_FUCT } \\
\text { PUL FUNCI }\end{array}$ \\
\hline & 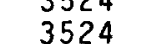 & M & $\begin{array}{l}\text { POL-FUNCT } \\
\text { PUL FUNCT }\end{array}$ \\
\hline 324 & 3524 & $\mathrm{~F}$ & $\begin{array}{l}\text { PUL-FUNCT } \\
\text { PUL F }\end{array}$ \\
\hline 327 & 3524 & $\mathrm{~F}$ & PUL FUNCT \\
\hline 328 & 3524 & $\mathrm{~F}$ & PUL FUNCT \\
\hline & $\begin{array}{l}3522 \\
3522\end{array}$ & $\mathrm{~F}$ & $\begin{array}{l}\text { PUL-FUNCT } \\
\text { DUU- }\end{array}$ \\
\hline $\begin{array}{l}129 \\
250\end{array}$ & $\begin{array}{l}3522 \\
3523\end{array}$ & $F_{M}$ & $\begin{array}{l}\text { PUL FUNT } \\
\text { PUI F }\end{array}$ \\
\hline 323 & $\begin{array}{l}3523 \\
3524\end{array}$ & $\begin{array}{c}M \\
F\end{array}$ & $\begin{array}{l}\text { PUL_FULCT } \\
\text { PULFUNCT }\end{array}$ \\
\hline 226 & $\begin{array}{l}3523 \\
3523\end{array}$ & $\mathrm{~F}$ & $\begin{array}{l}\text { PUL FUNCT } \\
\text { PUL_F F }\end{array}$ \\
\hline 342 & 3524 & M & PUL F UNCT \\
\hline 146 & 3522 & M & PUL_FUNCT \\
\hline 326 & 3524 & F & PUL_F UNCT \\
\hline $\begin{array}{l}321 \\
322 \\
322\end{array}$ & $\begin{array}{l}3524 \\
3524\end{array}$ & F & $\begin{array}{l}\text { PUL }{ }^{-F} \text { CUNCT } \\
\text { PUI }\end{array}$ \\
\hline & $\begin{array}{l}3524 \\
3524\end{array}$ & M & $\begin{array}{l}\text { POLLFUNC } \\
\text { PULFEUCT }\end{array}$ \\
\hline 128 & $\begin{array}{l}35<4 \\
3522\end{array}$ & $F$ & 作 \\
\hline 228 & 法 & $\mathrm{F}$ & PUL-FUCT \\
\hline 247 & 3523 & M & PUL_F UNCT \\
\hline 150 & 3522 & M & PUL_F UNCT \\
\hline 127 & & $F$ & PUL-FUNCT \\
\hline $\begin{array}{l}147 \\
350\end{array}$ & $\begin{array}{l}3522 \\
3524 \\
3524\end{array}$ & $M$ & $\begin{array}{l}\text { PUL FUNC } \\
\text { PUI FEUCI }\end{array}$ \\
\hline . & $\begin{array}{l}35<4 \\
3524\end{array}$ & 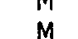 & $\begin{array}{l}\text { PUL_FUNC } \\
\text { PUI-FUNCI }\end{array}$ \\
\hline 225 & 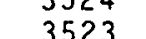 & $m_{E}^{M}$ & 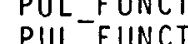 \\
\hline 121 & 3522 & $\mathrm{~F}$ & PULF FUNCT \\
\hline 343 & 3524 & M & PUL_FUNCT \\
\hline 221 & 3523 & $\mathrm{~F}$ & PUL_FUNCT \\
\hline 248 & $\begin{array}{l}3523 \\
3521\end{array}$ & $M$ & $\begin{array}{l}\text { PUL } \\
\text {-FUNCT }\end{array}$ \\
\hline $\begin{array}{l}348 \\
346\end{array}$ & $\begin{array}{l}\begin{array}{l}3524 \\
3524\end{array} \\
35\end{array}$ & $\begin{array}{c}M \\
M\end{array}$ & $\begin{array}{l}\text { PUL_FUNCT } \\
\text { PULFUNCT }\end{array}$ \\
\hline 230 & 3523 & $\mathrm{~F}$ & PUL_FUNCT \\
\hline $\begin{array}{l}222 \\
147\end{array}$ & $\begin{array}{l}3523 \\
35 ? 2\end{array}$ & F & $\begin{array}{l}\text { PUL-FUNCT } \\
\text { PUI-FUNT }\end{array}$ \\
\hline & & & \\
\hline
\end{tabular}

\begin{tabular}{cc}
$\begin{array}{c}\text { INITIAL } \\
\text { WEIGT } \\
(\mathrm{g})\end{array}$ & $\begin{array}{c}\text { ILB } \\
(\mathrm{kBQ} / \mathrm{g} / 9 \\
\text { LUNG) }\end{array}$ \\
\hline-36 & -0 \\
236 & 0 \\
252 & 0 \\
257 & 0 \\
252 & 0 \\
259 & 0 \\
251 & 0 \\
283 & 0 \\
263 & 0 \\
281 & 0 \\
242 & 0 \\
255 & 20 \\
257 & 20 \\
246 & 90 \\
163 & 110 \\
244 & 140 \\
251 & 150 \\
163 & 160 \\
249 & 160 \\
173 & 170 \\
170 & 170 \\
158 & 180 \\
160 & 200 \\
174 & 200 \\
270 & 220 \\
175 & 260 \\
156 & 270 \\
246 & 300 \\
264 & 310 \\
168 & 320 \\
157 & 330 \\
173 & 330 \\
263 & 360 \\
161 & 370 \\
176 & 390 \\
257 & 390 \\
265 & 450 \\
163 & 450 \\
242 & 510 \\
249 & 510 \\
249 & 620 \\
157 & 630 \\
167 & 680 \\
270 & 800 \\
158 & 820 \\
253 & 880 \\
258 & 910 \\
259 & 940 \\
153 & 970 \\
159 & 1000 \\
256 & 1020 \\
&
\end{tabular}

\begin{tabular}{|c|c|c|c|}
\hline DPE & $\begin{array}{l}30-D A Y \\
\text { GRAYS }\end{array}$ & $\begin{array}{l}900 \text {-DAY } \\
\text { GRAYS }\end{array}$ & $\begin{array}{l}\text { GRAYS } \\
\text { DEATH }\end{array}$ \\
\hline & & & 0 \\
\hline 623 & 0 & 0 & 0 \\
\hline $\begin{array}{l}623 \\
6026\end{array}$ & 0 & 0 & 0 \\
\hline $\begin{array}{l}606 \\
624\end{array}$ & 0 & 0 & $\begin{array}{l}0 \\
0\end{array}$ \\
\hline $\begin{array}{l}624 \\
624\end{array}$ & $\begin{array}{l}0 \\
0\end{array}$ & $\begin{array}{l}0 \\
0\end{array}$ & $\begin{array}{l}0 \\
0\end{array}$ \\
\hline 540 & 0 & 0 & 0 \\
\hline 540 & 0 & 0 & 0 \\
\hline $\begin{array}{l}540 \\
540\end{array}$ & $\begin{array}{l}0 \\
0\end{array}$ & $\begin{array}{l}0 \\
0\end{array}$ & $\begin{array}{l}0 \\
0\end{array}$ \\
\hline $\begin{array}{l}540 \\
540\end{array}$ & 1 & 10 & \\
\hline 540 & 1 & 10 & \\
\hline $\begin{array}{l}622 \\
620\end{array}$ & $\begin{array}{l}6 \\
7\end{array}$ & $\begin{array}{l}30 \\
40\end{array}$ & $\begin{array}{l}30 \\
30\end{array}$ \\
\hline 593 & 10 & 50 & 40 \\
\hline 623 & 10 & 50 & 50 \\
\hline $\begin{array}{l}619 \\
620\end{array}$ & $\begin{array}{l}11 \\
11\end{array}$ & $\begin{array}{l}50 \\
50\end{array}$ & $\begin{array}{l}50 \\
50\end{array}$ \\
\hline 540 & 11 & $\begin{array}{l}50 \\
50\end{array}$ & \\
\hline 620 & 11 & 50 & 50 \\
\hline $\begin{array}{r}539 \\
550\end{array}$ & 12 & 60 & 50 \\
\hline $\begin{array}{l}540 \\
540\end{array}$ & $\begin{array}{l}14 \\
14\end{array}$ & $\begin{array}{l}60 \\
60\end{array}$ & \\
\hline $\begin{array}{l}540 \\
612\end{array}$ & $\begin{array}{l}15 \\
18\end{array}$ & $\begin{array}{l}70 \\
80\end{array}$ & \\
\hline $\begin{array}{l}612 \\
620\end{array}$ & $\begin{array}{l}18 \\
18\end{array}$ & $\begin{array}{l}80 \\
90\end{array}$ & $\begin{array}{l}80 \\
80\end{array}$ \\
\hline 488 & 20 & 90 & 90 \\
\hline $\begin{array}{l}624 \\
615\end{array}$ & $\begin{array}{l}21 \\
21\end{array}$ & $\begin{array}{l}100 \\
100\end{array}$ & $\begin{array}{r}90 \\
100\end{array}$ \\
\hline 623 & 23 & 110 & 100 \\
\hline 619 & 22 & 110 & 100 \\
\hline 59 & 24 & 110 & 110 \\
\hline $\begin{array}{l}622 \\
622\end{array}$ & $\begin{array}{l}25 \\
26\end{array}$ & $\begin{array}{l}200 \\
120\end{array}$ & $\begin{array}{l}110 \\
120\end{array}$ \\
\hline 65 & 27. & 130 & \\
\hline & $\begin{array}{l}30 \\
31\end{array}$ & $\begin{array}{l}140 \\
140\end{array}$ & 140 \\
\hline 62 & 34 & 160 & 150 \\
\hline 623 & 34 & 160 & 150 \\
\hline 62 & 42 & 190 & 190 \\
\hline & $\begin{array}{l}42 \\
46\end{array}$ & $\begin{aligned} 200 \\
220\end{aligned}$ & $\begin{array}{l}190 \\
200\end{array}$ \\
\hline & $\begin{array}{l}46 \\
54\end{array}$ & $\begin{array}{l}220 \\
250\end{array}$ & $\begin{array}{l}250 \\
250\end{array}$ \\
\hline & $\begin{array}{l}54 \\
55\end{array}$ & 260 & 240 \\
\hline & 60 & 280 & 260 \\
\hline & 61 & 290 & 280 \\
\hline & 63 & 300 & 290 \\
\hline & 66 & 310 & 270 \\
\hline & 61 & $\begin{array}{r}320 \\
320\end{array}$ & $\begin{array}{l}290 \\
300\end{array}$ \\
\hline
\end{tabular}

MODE OF DEATH

SAC EXAMAMINED
SAC-EXAMAMINED SAC EXAMAMINED

ALIVE
ALIVE
ALIVE
ALIVE
ALIVE

ALIVE

SAC EXAMAMINED DIED SAC-EXAMAMINED ALIVE EXAMAMINED EUTHANIZED

ALIVE
ALIVE

ALIVE SAC EXAMAMINED EUTHANIZED EUTHANIZED SAC-EXAMAMINED UTHANIZED SAC EXAMAMINED AL

SAC EXAMAMINED SAC-EXAMAMINE SAC EXAMAMINED SAC EXAMAMINED SAC EXAMAMINED SAC EXAMAMI
EUTHANIZED DIED SAC_EXAMAMIN SAC EXAMAMINED
DIED
DIED DIED
EUTHANIZED

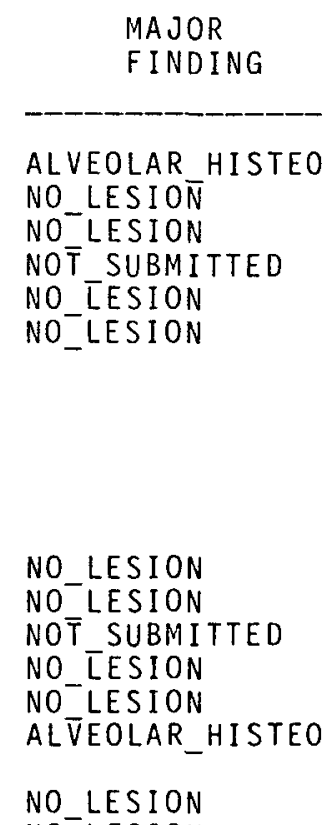

No-LESION
NO-LESION

NOT SUBMITED
ALVEOLAR HISTEO ALVEOLAR ${ }^{-}$ISTEO NOT SUBMITTED NO LESION
NO-LESION UNRESOLVED
ALVEOLAR HISTEO SQUAM CELL CA

ALVEOLAR HISTEO BA- HYPERP LASIA
BA-HYPERPLASIA ALVEOLAR HISTEO SQUAM CELL CA ALVEOLAR HISTEO
NOT SUBMITTED SQUAMM CELL_CA BA- HYPRPLASIA SOUAM CELLCA
RAD PNEUMONITIS HEMORRAGGE SQUAM_CELL_CA
ALVEOLAR_HISTEO LEUKEMIA
OTHER FINDINGS AT DEATH

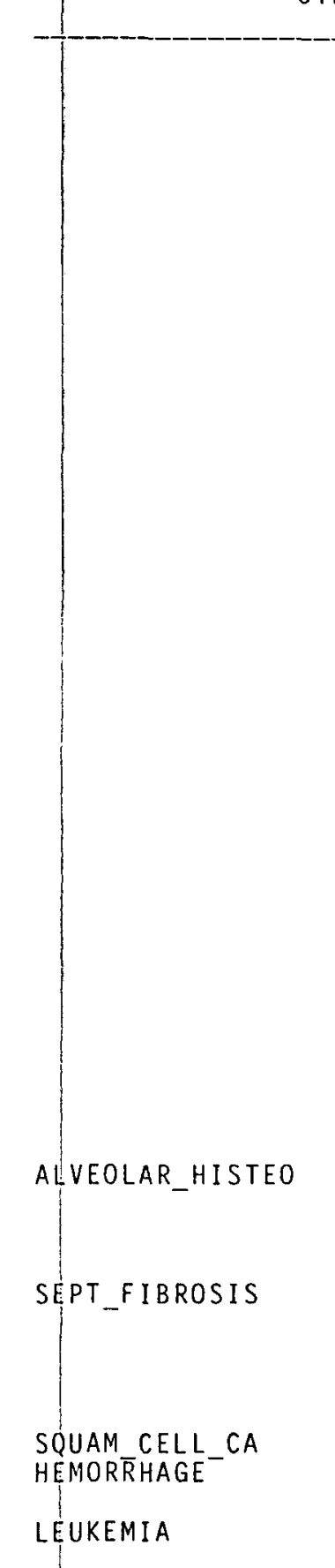


2F. PATHOLOGICAL OBSERVATIONS AND OTHER COMMENTS FOR RATS THAT DIED, WERE SACRIFICED OR EUTHANIZED AFTER INHALATION EXPOSURE TO SRgO-FAP

\begin{tabular}{|c|c|c|c|c|c|c|c|c|c|c|c|c|}
\hline $\begin{array}{l}\text { ANIMAL L } \\
\text { NUMBER }\end{array}$ & $\begin{array}{l}\text { EXPERI- } \\
\text { MENTI } \\
\text { NUBBER }\end{array}$ & SEX & GROUP & $\begin{array}{c}\text { INIIIAL } \\
\text { WEIGHT } \\
(g)\end{array}$ & 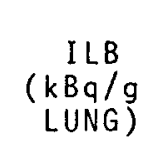 & DPE & $\begin{array}{l}\text { 30-DAY } \\
\text { GRAYS }\end{array}$ & $\begin{array}{l}900-0 \mathrm{Ar} \\
\text { GRAYS }\end{array}$ & $\begin{array}{l}\text { GRAYS AT } \\
\text { DEATH }\end{array}$ & MODE OF DEATH & $\begin{array}{l}\text { MAJOR } \\
\text { FINOING }\end{array}$ & OTHER FINDINGS AT DEATH \\
\hline $\begin{array}{l}227 \\
229 \\
242 \\
148 \\
246 \\
244 \\
223 \\
243 \\
245 \\
122 \\
224 \\
249 \\
130\end{array}$ & $\begin{array}{l}3523 \\
35523 \\
3523 \\
3522 \\
3522 \\
3523 \\
3523 \\
3523 \\
3523 \\
3523 \\
3522 \\
3523 \\
3523 \\
3523 \\
3522\end{array}$ & $\begin{array}{c}F \\
F \\
M \\
M \\
M \\
M \\
M \\
M \\
M \\
M \\
F \\
F \\
M \\
M\end{array}$ & 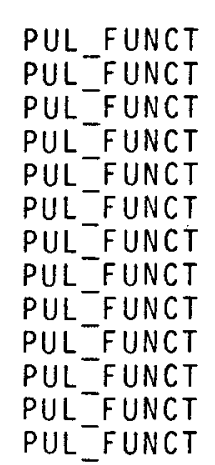 & $\begin{array}{l}158 \\
165 \\
229 \\
255 \\
252 \\
252 \\
258 \\
243 \\
252 \\
259 \\
169 \\
259 \\
256\end{array}$ & $\begin{array}{l}1100 \\
1150 \\
1160 \\
1220 \\
1370 \\
1400 \\
1480 \\
1510 \\
1780 \\
1780 \\
1800 \\
2000\end{array}$ & $\begin{array}{l}403 \\
458 \\
504 \\
486 \\
89 \\
369 \\
503 \\
306 \\
437 \\
125 \\
179 \\
149 \\
182\end{array}$ & $\begin{array}{l}74 \\
77 \\
78 \\
142 \\
160 \\
164 \\
174 \\
177 \\
197 \\
208 \\
212 \\
234 \\
346\end{array}$ & $\begin{array}{c}350 \\
360 \\
370 \\
640 \\
720 \\
740 \\
780 \\
800 \\
890 \\
940 \\
960 \\
1060 \\
1560\end{array}$ & $\begin{array}{c}300 \\
330 \\
330 \\
620 \\
360 \\
690 \\
750 \\
700 \\
850 \\
570 \\
700 \\
710 \\
1160\end{array}$ & 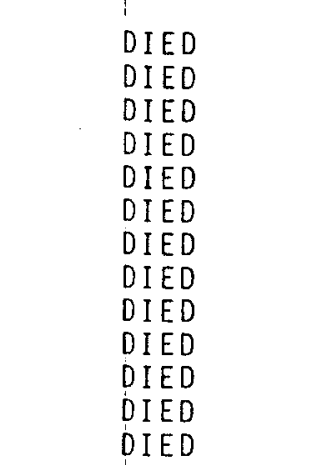 & 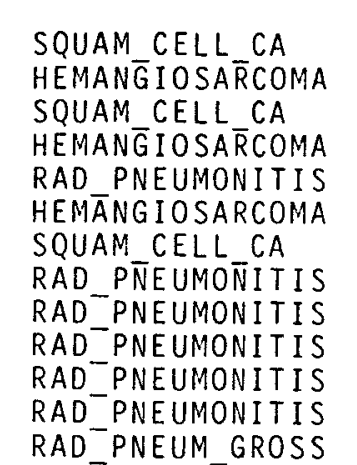 & 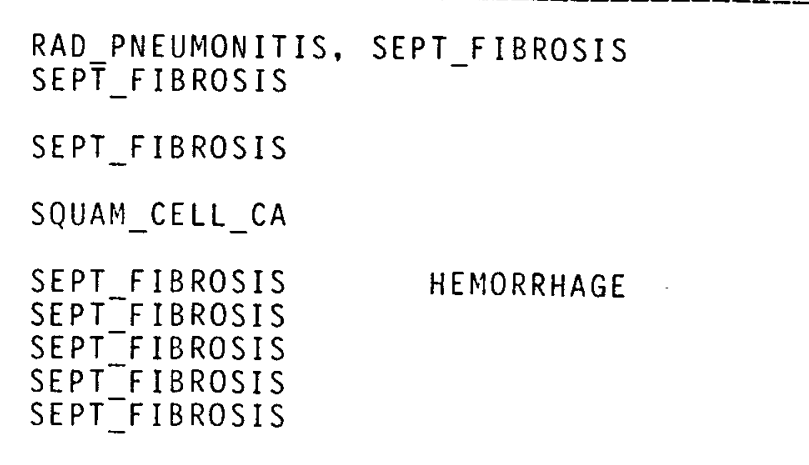 \\
\hline
\end{tabular}


3A. PATHOLOGICAL OBSERVATIONS AND OTHER COMMENTS FOR RATS THAT DIED, WERE SACRIFICED OR EUTHANIZED AFTER INHALATION EXPOSURE TO YgO-FAP

EXPERI-

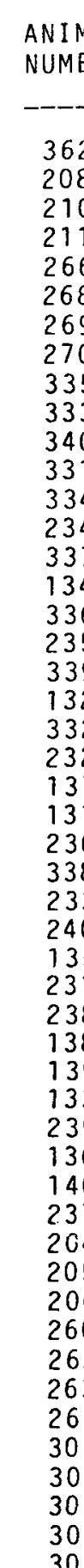

\begin{tabular}{|c|c|c|c|c|c|}
\hline $\begin{array}{l}\text { INITIALL } \\
\text { WEIGH } \\
(g)\end{array}$ & 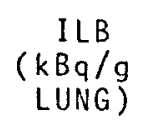 & DPE & $\begin{array}{l}30-0 A Y \\
\text { GRAYS }\end{array}$ & $\begin{array}{l}900-0 \mathrm{DAY} \\
\text { GRAYS }\end{array}$ & $\begin{array}{l}\text { GRAYS AT } \\
\text { DEATH }\end{array}$ \\
\hline $\begin{array}{l}292 \\
153\end{array}$ & & $\begin{array}{l}540 \\
540 \\
540\end{array}$ & 0 & $\begin{array}{l}0 \\
0 . \\
0 .\end{array}$ & $\begin{array}{l}0 \\
0\end{array}$ \\
\hline $\begin{array}{l}158 \\
154 \\
154\end{array}$ & & $\begin{array}{l}540 \\
540\end{array}$ & $\begin{array}{l}0 \\
0 \\
0\end{array}$ & $\begin{array}{l}0 \\
0 . \\
0 .\end{array}$ & 0 \\
\hline $\begin{array}{l}292 \\
298\end{array}$ & $\begin{array}{l}0 \\
0 \\
0\end{array}$ & $\begin{array}{r}540 \\
511 \\
511\end{array}$ & $\begin{array}{l}0 \\
0 \\
0\end{array}$ & $\begin{array}{l}0 \\
0 \\
0\end{array}$ & $\begin{array}{l}0 \\
0 \\
0\end{array}$ \\
\hline $\begin{array}{l}514 \\
309 \\
360\end{array}$ & $\begin{array}{r}0 \\
0\end{array}$ & $\begin{array}{c}540 \\
540 \\
500\end{array}$ & $\begin{array}{c}0 \\
0 \\
28\end{array}$ & $\begin{array}{r}0 \\
0 \\
5\end{array}$ & $\begin{array}{l}0 \\
0\end{array}$ \\
\hline 179 & 4240 & $\begin{array}{c}540 \\
540 \\
540\end{array}$ & $\begin{array}{l}38 \\
688 \\
68\end{array}$ & $\begin{array}{l}500 \\
100\end{array}$ & \\
\hline 166 & $\begin{array}{l}4580 \\
4680 \\
5250\end{array}$ & $\begin{array}{l}540 \\
540 \\
540\end{array}$ & $\begin{array}{l}79 \\
75 \\
84\end{array}$ & $\begin{array}{l}110 \\
120\end{array}$ & \\
\hline 170 & $\begin{array}{l}6790 \\
67320\end{array}$ & $\begin{array}{l}540 \\
540\end{array}$ & $\begin{array}{l}109 \\
117\end{array}$ & $\begin{array}{l}160 \\
170 \\
170\end{array}$ & \\
\hline 174 & $\begin{array}{l}7420 \\
8700\end{array}$ & $\begin{array}{l}161 \\
540\end{array}$ & $\begin{array}{l}119 \\
129\end{array}$ & $\begin{array}{l}170 \\
190\end{array}$ & 130 \\
\hline $\begin{array}{l}173 \\
241\end{array}$ & $\begin{array}{l}8120 \\
8210\end{array}$ & $\begin{array}{l}540 \\
602\end{array}$ & $\begin{array}{l}130 \\
131\end{array}$ & $\begin{array}{l}190 \\
190\end{array}$ & \\
\hline 169 & 8300 & 79 & 133 & 190 & 140 \\
\hline $\begin{array}{l}158 \\
163 \\
221\end{array}$ & $\begin{array}{l}8790 \\
8930 \\
0320\end{array}$ & $\begin{array}{r}10 \\
85 \\
5\end{array}$ & $\begin{array}{l}139 \\
1450\end{array}$ & $\begin{array}{l}210 \\
210\end{array}$ & $\begin{array}{l}140 \\
150\end{array}$ \\
\hline 168 & 9430 & $\begin{array}{r}90 \\
93\end{array}$ & $\begin{array}{l}150 \\
155\end{array}$ & $\begin{array}{l}120 \\
220\end{array}$ & 160 \\
\hline 228 & $\begin{array}{l}97200 \\
.9850\end{array}$ & $\begin{array}{l}540 \\
540\end{array}$ & $\begin{array}{l}155 \\
157\end{array}$ & 2301 & \\
\hline $\begin{array}{l}166 \\
228\end{array}$ & $\begin{array}{l}11550 \\
11570\end{array}$ & $\begin{array}{l}94 \\
71\end{array}$ & $\begin{array}{l}185 \\
185 \\
185\end{array}$ & $\begin{array}{l}270 \\
270\end{array}$ & $\begin{array}{l}190 \\
190\end{array}$ \\
\hline $\begin{array}{l}164 \\
217\end{array}$ & $\begin{array}{l}12710 \\
12710\end{array}$ & $\begin{array}{r}79 \\
790\end{array}$ & 203 & $\begin{array}{l}300^{\circ} \\
320^{2}\end{array}$ & 210 \\
\hline $\begin{array}{l}241 \\
241 \\
221\end{array}$ & $\begin{array}{l}13800 \\
1300 \\
1360\end{array}$ & $\begin{array}{l}540 \\
540 \\
550\end{array}$ & $\begin{array}{l}200 \\
218 \\
218\end{array}$ & $\begin{array}{l}300 \\
300 \\
320\end{array}$ & \\
\hline $\begin{array}{l}167 \\
2267\end{array}$ & $\begin{array}{l}14150 \\
18150\end{array}$ & $\begin{array}{l}63 \\
76\end{array}$ & $\begin{array}{l}226 \\
288 \\
288\end{array}$ & $\begin{array}{l}330^{\circ} \\
420\end{array}$ & $\begin{array}{r}230 \\
300 \\
300\end{array}$ \\
\hline $\begin{array}{l}228 \\
216\end{array}$ & $\begin{array}{l}185000 \\
18720\end{array}$ & $\begin{array}{l}68 \\
67\end{array}$ & $\begin{array}{l}296 \\
299 \\
299\end{array}$ & $\begin{array}{l}30 \\
440\end{array}$ & $\begin{array}{l}300 \\
300\end{array}$ \\
\hline 556 & & $\begin{array}{r}52 \\
540\end{array}$ & $\begin{array}{r}348 \\
0\end{array}$ & $\begin{array}{r}r 10 \\
0 \\
0\end{array}$ & \\
\hline $\begin{array}{l}150 \\
201\end{array}$ & 0 & 540 & 0 & 0 & 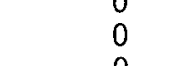 \\
\hline $\begin{array}{l}297 \\
297\end{array}$ & $\begin{array}{l}0 \\
0 \\
0\end{array}$ & $\begin{array}{l}487 \\
450\end{array}$ & $\begin{array}{l}0 \\
0\end{array}$ & $\begin{array}{l}0 \\
0 \\
0\end{array}$ & 0 \\
\hline 168 & $\begin{array}{l}0 \\
0 \\
0\end{array}$ & $\begin{array}{l}540 \\
540\end{array}$ & $\begin{array}{l}0 \\
0\end{array}$ & $\begin{array}{c}0 \\
0 \\
0\end{array}$ & 0 \\
\hline & & $\begin{array}{l}540 \\
550\end{array}$ & $\begin{array}{l}0 \\
0\end{array}$ & $\begin{array}{l}0 \\
0\end{array}$ & $\begin{array}{l}0 \\
0\end{array}$ \\
\hline 156 & 0 & $\begin{array}{l}540 \\
540\end{array}$ & $\begin{array}{l}0 \\
0\end{array}$ & $\begin{array}{l}0 \\
0\end{array}$ & 0 \\
\hline
\end{tabular}

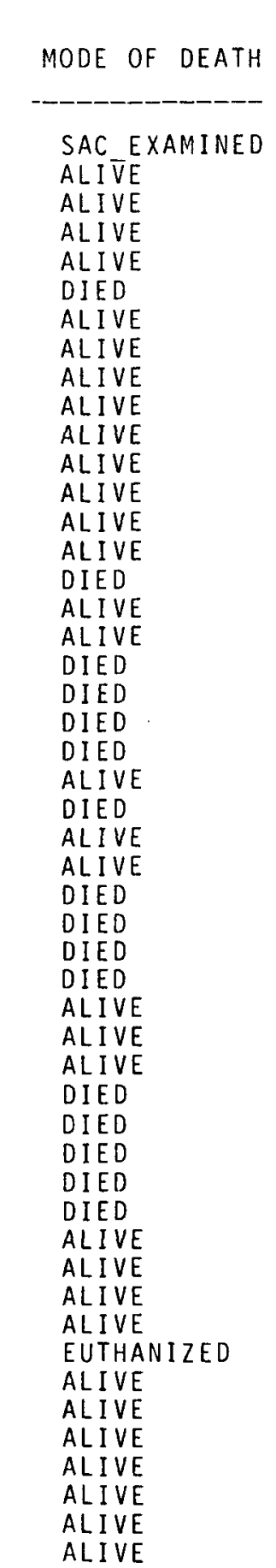
MAJOR
FINOING NO_LESIONS

LEUKEMIA

UNRESOLVED

NOT_SUBMITED
RAD-PNEUMONITIS RAD PNEUMONIIS
RAD PNEUMONIIS RAD_PNEUMONITIS

RAD PPEUMONIIS
RAD-PNEUMONITIS RAO-PNEUMONITIS
RAD-PNEUMONIIS

RAD_PNEUMONITIS

RAD-PNEUMONITIS

RAD-PNEUMONITIS
RADPNEUMONITIS

NOT_SUBMitTed
OTHER FINDINGS AT DEATH

$$
\begin{aligned}
& \text { SEPT_FIBROSIS } \\
& \text { SEPT-FIBROSIS } \\
& \text { SEPT_FIBROSIS } \\
& \text { SEPT_FIBROSIS } \\
& \text { SEPT-FIBROSIS } \\
& \text { SEPT_FIBROSIS } \\
& \text { SEPT_FIBROSIS } \\
& \text { SEPT-FIBROSIS } \\
& \text { SEPT_FIBROSIS } \\
& \text { SEPT_FIBROSIS }
\end{aligned}
$$


38. PATHOLOGICAL OBSERVATIONS AND OtHER COMMENTS FOR RATS. THAT DIED, WERE SACRIFICED OR EUTHANIZED AFTER INHALATION EXPOSURE TO Y9O-FAP

\begin{tabular}{|c|c|c|c|}
\hline $\begin{array}{l}\text { ANIMA } \\
\text { NUMBEE}\end{array}$ & $\begin{array}{l}\text { MEN } \\
\text { NENT } \\
\text { NUMBRR }\end{array}$ & SEX & GROUP \\
\hline 200 & 2525 & $F$ & MORTALITY \\
\hline $\begin{array}{l}310 \\
311\end{array}$ & 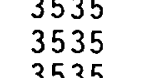 & 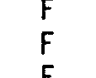 & $\begin{array}{l}\text { NoRTRALITY } \\
\text { MORTLL IT }\end{array}$ \\
\hline $\begin{array}{l}360 \\
361\end{array}$ & 35 & M & $\begin{array}{l}\text { MORTALITY } \\
\text { OLRTA }\end{array}$ \\
\hline $\begin{array}{l}364 \\
365\end{array}$ & $\begin{array}{l}3535 \\
355\end{array}$ & 管 & $\begin{array}{l}\text { MoRTALITY } \\
\text { OORTAL }\end{array}$ \\
\hline $\begin{array}{l}366 \\
367\end{array}$ & & $\stackrel{M}{M}$ & $\begin{array}{l}\text { MORTAL } \\
\text { MORTAL }\end{array}$ \\
\hline $\begin{array}{l}368 \\
369 \\
369\end{array}$ & & $\stackrel{M}{M}$ & $\begin{array}{l}\text { ORRTALLY } \\
\text { MORTLLIT }\end{array}$ \\
\hline 320 & $\begin{array}{l}3535 \\
3535 \\
3535\end{array}$ & F & $\begin{array}{l}\text { MOR } \\
\text { MORTALIITY }\end{array}$ \\
\hline $\begin{array}{l}546 \\
319\end{array}$ & 353 & F & MORTALITY \\
\hline 328 & $\begin{array}{l}35353 \\
3255 \\
3252\end{array}$ & F & MORTALITY \\
\hline $\begin{array}{l}325 \\
324\end{array}$ & $\begin{array}{r}353 \\
353 \\
353\end{array}$ & $F$ & MORTALTY \\
\hline $\begin{array}{l}330 \\
307\end{array}$ & $\begin{array}{r}3535 \\
3525\end{array}$ & F & $\begin{array}{l}\text { MORTALI IY } \\
\text { MOLTS }\end{array}$ \\
\hline $\begin{array}{l}314 \\
327\end{array}$ & $\begin{array}{l}353 \\
353 \\
353\end{array}$ & $\mathrm{~F}$ & MORTALITY \\
\hline $\begin{array}{l}323 \\
355 \\
355\end{array}$ & $\begin{array}{l}3535 \\
3553 \\
3\end{array}$ & F & $\begin{array}{l}\text { MORTALI } \\
\text { MORTALIT }\end{array}$ \\
\hline 118 & $\begin{array}{l}3533 \\
3534\end{array}$ & $\stackrel{F}{F}$ & $\begin{array}{l}\text { MORTALLIYY } \\
\text { MORTALITT }\end{array}$ \\
\hline $\begin{array}{l}111 \\
226\end{array}$ & $\begin{array}{l}3533 \\
3534 \\
\end{array}$ & F & $\begin{array}{l}\text { OORTALLTY } \\
\text { MORTALITY }\end{array}$ \\
\hline $\begin{array}{l}229 \\
123\end{array}$ & $\begin{array}{l}3534 \\
3533 \\
353\end{array}$ & $F$ & $\begin{array}{l}\text { OORTALITY } \\
\text { MORTALI ITY }\end{array}$ \\
\hline $\begin{array}{l}112 \\
358 \\
358\end{array}$ & $\begin{array}{l}35 \\
35 \\
3.5\end{array}$ & M & $\begin{array}{l}\text { MORTALITY } \\
\text { MORTLI TS }\end{array}$ \\
\hline $\begin{array}{l}230 \\
349 \\
349\end{array}$ & & M & $\begin{array}{l}\text { MORTAL IY } \\
\text { MORTI }\end{array}$ \\
\hline $\begin{array}{l}347 \\
218\end{array}$ & & M & $\begin{array}{l}\text { MORTALI Y } \\
\text { MoRTAI }\end{array}$ \\
\hline $\begin{array}{l}321 \\
159\end{array}$ & $\begin{array}{l}35 \\
35 \\
5\end{array}$ & F & $\begin{array}{l}\text { MoRTALI I } \\
\text { MORTALI }\end{array}$ \\
\hline $\begin{array}{l}356 \\
216\end{array}$ & 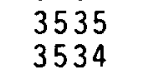 & ${ }_{F}^{M}$ & $\begin{array}{l}\text { MORTAL I I } \\
\text { MORTALT }\end{array}$ \\
\hline 10 & $\begin{array}{l}35 . \\
35\end{array}$ & $\stackrel{F}{F}$ & $\begin{array}{l}\text { MoRTALLI } \\
\text { MORTLIT }\end{array}$ \\
\hline & & 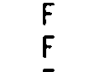 & $\begin{array}{l}\text { OORTALLI TY } \\
\text { MORTALIT }\end{array}$ \\
\hline 100 & & 票 & MORTALIT \\
\hline
\end{tabular}

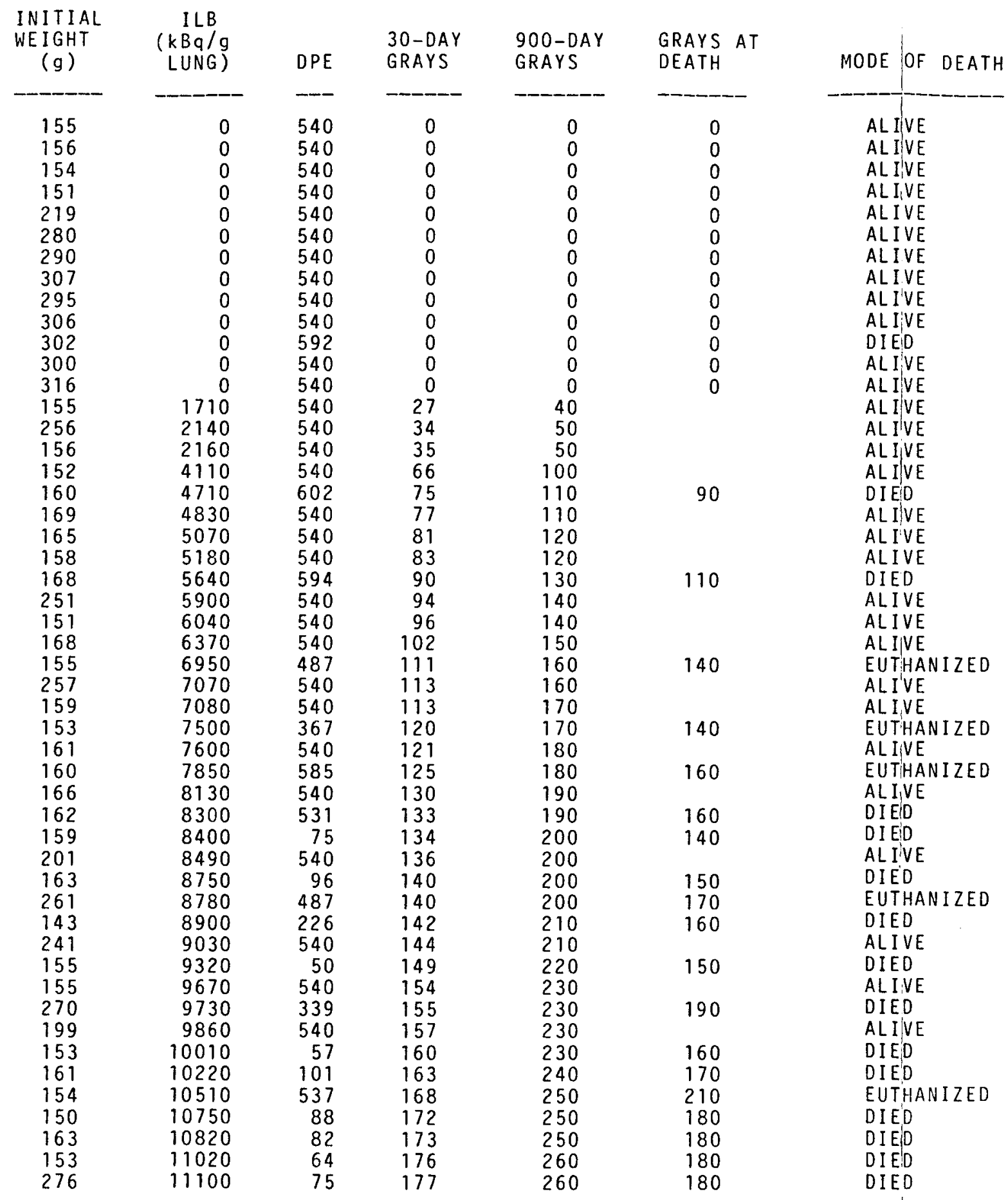

$\underset{\substack{\text { MAJOR } \\ \text { FINOING }}}{\text { M }}$

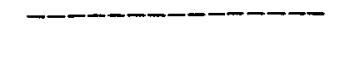

NOT_SUBMITTED

NOT_SUBMitTED

RAD_PNEUMONITIS

BA_HYPERPLASIA

NO LESIONS

RAD_PNEUMONITIS RAD_PNEUMONITIS
RAD_PNEUMONITIS

RAD PNEUMONITIS

NO_LESIONS
RAD_PNEUMONITIS

RAD PNEUMONITIS

LEUKEMIA

RAD PNEUMONITIS
RAD PNEUMONITIS

RAD PNEUMON IT IS
RAD-PNEUMONIT IS

RAD-PNEUMONITIS

RAD-PNEUMONITS
RAD_PNEUMONITIS

SEPT FIBROSIS

ADENŌ CARC INOMA

SEPT_FIBROSIS 
3C. PATHOLOGICAL OBSERVATIONS AND OTHER COMMENTS FOR RATS THAT DIED, WERE SACRIFICED OR EUTHANIZED AFTER INHALATION EXPOSURE TO Y9O-FAP

\begin{tabular}{|c|c|c|c|c|c|c|c|c|c|c|}
\hline $\begin{array}{l}\text { ANIMAL } \\
\text { NUMBER }\end{array}$ & $\begin{array}{l}\text { EXPERI- } \\
\text { MENT } \\
\text { NUMBER }\end{array}$ & SEX & GROUP & $\begin{array}{l}\text { INITIAL } \\
\text { WEIGHT } \\
(g)\end{array}$ & $\begin{array}{c}\mathrm{ILB} \\
(\mathrm{kBq} / \mathrm{g} \\
\mathrm{LUNG})\end{array}$ & DPE & $\begin{array}{l}\text { 30-DAY } \\
\text { GRAYS }\end{array}$ & $\begin{array}{l}\text { 900-DAY } \\
\text { GRAYS }\end{array}$ & $\begin{array}{l}\text { GRAYS AT } \\
\text { DEATH }\end{array}$ & MODE OF DEATH \\
\hline 124 & 3533 & $\mathrm{~F}$ & MORTALITY & 155 & 11240 & 53 & 180 & 260 & 180 & DIED \\
\hline $\begin{array}{l}155 \\
220\end{array}$ & $\begin{array}{l}3533 \\
3534\end{array}$ & $\stackrel{M}{\mathrm{M}}$ & $\begin{array}{l}\text { MORTALITY } \\
\text { MORTALITY }\end{array}$ & $\begin{array}{l}264 \\
158\end{array}$ & $\begin{array}{l}11240 \\
11280\end{array}$ & $\begin{array}{r}474 \\
68\end{array}$ & $\begin{array}{l}180 \\
180\end{array}$ & $\begin{array}{l}260 \\
260\end{array}$ & $\begin{array}{l}220 \\
180\end{array}$ & $\begin{array}{l}\text { DIED } \\
\text { DIED }\end{array}$ \\
\hline 351 & $\begin{array}{l}5534 \\
3535\end{array}$ & $\mathrm{M}$ & MORTALI TY & $\begin{array}{l}158 \\
251\end{array}$ & 11300 & 274 & 180 & $\begin{array}{l}260 \\
260\end{array}$ & $\begin{array}{l}180 \\
210\end{array}$ & EUTHAN I ZED \\
\hline 143 & 3533 & M & MORTALITY & 233 & 11420 & 435 & 182 & 270 & 220 & DIED \\
\hline $\begin{array}{l}248 \\
117\end{array}$ & $\begin{array}{l}3534 \\
3533 \\
3533\end{array}$ & $\underset{F}{M}$ & MORTALITY & $\begin{array}{l}247 \\
154\end{array}$ & $\begin{array}{l}11560 \\
11590\end{array}$ & 104 & $\begin{array}{l}185 \\
185\end{array}$ & $\begin{array}{l}270 \\
270\end{array}$ & 200 & DIED \\
\hline 111 & $\begin{array}{l}3533 \\
3533\end{array}$ & $\mathrm{~F}$ & MORTALITY & $\begin{array}{l}154 \\
147\end{array}$ & $\begin{array}{l}11590 \\
11700\end{array}$ & $\begin{array}{l}12 \\
65\end{array}$ & $\begin{array}{l}185 \\
187\end{array}$ & $\begin{array}{l}270 \\
270\end{array}$ & $\begin{array}{l}190 \\
190\end{array}$ & $\begin{array}{l}\text { DIED } \\
\text { DIED }\end{array}$ \\
\hline 221 & 3534 & $\mathrm{~F}$ & MORTAL ITY & 157 & 11710 & 540 & 187 & 270 & & ALIVE \\
\hline 119 & 3533 & $F$ & MORTALI TY & 160 & 11890 & 88 & 190 & 280 & 200 & DIED \\
\hline $\begin{array}{l}144 \\
357\end{array}$ & $\begin{array}{l}3533 \\
3535\end{array}$ & $M$ & $\begin{array}{l}\text { MORTALITY } \\
\text { MORTAL ITY }\end{array}$ & $\begin{array}{l}246 \\
202\end{array}$ & $\begin{array}{l}12070 \\
12170\end{array}$ & $\begin{array}{r}65 \\
540\end{array}$ & $\begin{array}{l}193 \\
194\end{array}$ & $\begin{array}{l}280 \\
280\end{array}$ & 200 & $\begin{array}{l}\text { DIED } \\
\text { ALIVE }\end{array}$ \\
\hline 222 & $\begin{array}{l}3535 \\
3534\end{array}$ & F & MORTALITY & 150 & 12220 & $\begin{array}{r}540 \\
61\end{array}$ & $\begin{array}{l}194 \\
195\end{array}$ & 290 & 200 & $\begin{array}{l}\text { DIED } \\
\text { DIVE }\end{array}$ \\
\hline 354 & $\begin{array}{r}3534 \\
3535\end{array}$ & $M$ & MORTALITY & 258 & 12290 & 63 & 196 & 290 & 200 & $\begin{array}{l}\text { DIED } \\
\text { DIED }\end{array}$ \\
\hline 145 & 3533 & M & MORTALITY & 248 & 12400 & 488 & 198 & 290 & 240 & EUTHANIZED \\
\hline 348 & 3535 & $M$ & MORTALI IY & 249 & 12420 & 246 & 198 & 290 & 230 & DIED \\
\hline 250 & $\begin{array}{l}3534 \\
25.55\end{array}$ & $M$ & MORTAL ITY & 291 & 12890 & 63 & 206 & 300 & 210 & DIED \\
\hline $\begin{array}{l}350 \\
243\end{array}$ & $\begin{array}{l}3535 \\
3534\end{array}$ & $M$ & $\begin{array}{l}\text { MORTALITY } \\
\text { MORTAL }\end{array}$ & $\begin{array}{l}250 \\
245\end{array}$ & 12990 & $\begin{array}{r}72 \\
500\end{array}$ & 208 & 300 & 210 & DIED \\
\hline $\begin{array}{l}243 \\
152\end{array}$ & $\begin{array}{l}\begin{array}{l}53544 \\
3533\end{array} \\
\end{array}$ & $\stackrel{M}{M}$ & $\begin{array}{l}\text { MORTAL I TY } \\
\text { MORTAL TTY }\end{array}$ & $\begin{array}{l}245 \\
251\end{array}$ & $\begin{array}{l}33060 \\
13170\end{array}$ & $\begin{array}{r}540 \\
79\end{array}$ & 209 & $\begin{array}{l}300 \\
310\end{array}$ & 220 & $\begin{array}{l}\text { ALIVE } \\
\text { DIED }\end{array}$ \\
\hline 103 & $\begin{array}{l}3533 \\
3533\end{array}$ & $\mathrm{~F}$ & MORTAL I TY & 152 & 13380 & $\begin{array}{l}19 \\
66\end{array}$ & 214 & 310 & $\begin{array}{l}220 \\
220\end{array}$ & DIED \\
\hline 106 & 3533 & $\mathrm{~F}$ & MORTALITY & 145 & 13440 & 54 & 215 & 310 & 210 & DIED \\
\hline 228 & 3534 & $\mathrm{~F}$ & MORTALITY & 153 & 14130 & 48 & 226 & 330 & 220 & $\begin{array}{l}\text { DIED } \\
\text { DIED }\end{array}$ \\
\hline 164 & 3533 & M & MORTAL I TY & 271 & 14380 & 62 & 230 & 340 & 230 & DIED \\
\hline 163 & 3533 & M & MORTAL I TY & 267 & 14470 & 74 & 231 & 340 & 240 & DIED \\
\hline $\begin{array}{l}214 \\
207\end{array}$ & $\begin{array}{l}3534 \\
3534\end{array}$ & $F$ & MORTAL I TY & $\begin{array}{l}140 \\
254\end{array}$ & 14580 & 58 & $\begin{array}{l}233 \\
222\end{array}$ & 340 & 230 & DIED \\
\hline & $\begin{array}{l}3534 \\
3533\end{array}$ & $M$ & $\begin{array}{l}\text { MORTALITY } \\
\text { MORTAL ITY }\end{array}$ & $\begin{array}{l}254 \\
275\end{array}$ & $\begin{array}{l}44590 \\
15080\end{array}$ & $\begin{array}{l}81 \\
56\end{array}$ & $\begin{array}{l}233 \\
241\end{array}$ & $\begin{array}{l}340 \\
350\end{array}$ & $\begin{array}{l}240 \\
240\end{array}$ & $\begin{array}{l}\text { DIED } \\
\text { DIED }\end{array}$ \\
\hline $\begin{array}{l}100 \\
105\end{array}$ & 3533 & $\mathrm{~F}$ & MORTALITY & $\begin{array}{l}215 \\
148\end{array}$ & $\begin{array}{l}15080 \\
15250\end{array}$ & $\begin{array}{lll}50 \\
54\end{array}$ & $\begin{array}{l}241 \\
244\end{array}$ & 作 & 240 & $\begin{array}{l}\text { DIED } \\
\text { DIED }\end{array}$ \\
\hline 167 & 3533 & M & MORTALITY & $\begin{array}{l}270 \\
272\end{array}$ & 15470 & 126 & 247 & 360 & 270 & DIED \\
\hline 255 & 3534 & M & MOR TAL ITY & 253 & 15620 & 108 & 250 & 360 & 270 & $\begin{array}{l}\text { EUTHANIZED } \\
\text { EUTHAIZE }\end{array}$ \\
\hline 219 & 3534 & $\mathrm{~F}$ & MORTALITY & 137 & 15750 & 57 & 252 & 370 & 250 & DIED \\
\hline 148 & 3533 & $M$ & & 254 & 16000 & 72 & 256 & 370 & 260 & DIED \\
\hline $\begin{array}{l}150 \\
227\end{array}$ & $\begin{array}{l}3533 \\
3534\end{array}$ & $M_{F}^{M}$ & MORTAL I TY & 248 & $\begin{array}{l}16020 \\
16190\end{array}$ & 71 & $\begin{array}{l}256 \\
250 \\
250\end{array}$ & $\begin{array}{l}370 \\
380\end{array}$ & $\begin{array}{l}260 \\
260\end{array}$ & $\begin{array}{l}\text { DIED } \\
\text { DIFD }\end{array}$ \\
\hline 149 & $\begin{array}{l}35344 \\
3533\end{array}$ & ${ }_{M}^{r}$ & MORTALITY & $\begin{array}{l}339 \\
253\end{array}$ & $\begin{array}{l}16240 \\
16240\end{array}$ & $\begin{array}{l}65 \\
65\end{array}$ & $\begin{array}{l}259 \\
259\end{array}$ & $\begin{array}{l}380 \\
380\end{array}$ & $\begin{array}{l}260 \\
260\end{array}$ & $\begin{array}{l}\text { DIED } \\
\text { DIED }\end{array}$ \\
\hline 245 & 3534 & M & MORTALITY & 243 & 16530 & 73 & 264 & 390 & 270 & DIED \\
\hline 249 & 3534 & $M$ & MORTALITY & 241 & & 59 & & 39 & & DIED \\
\hline 109 & 3533 & $\mathrm{~F}$ & MORTAL ITY & 150 & 17100 & 52 & 273 & 400 & 270 & DIED \\
\hline 147 & 3533 & M & MORTALITY & 253 & 17260 & 73 & 276 & 400 & 280 & DIED \\
\hline 162 & 3533 & M & MORTALITY & 2 & 17310 & 53 & 277 & 400 & 280 & DIED \\
\hline 254 & $\begin{array}{l}3534 \\
2532\end{array}$ & $M$ & MORTALI IY & 251 & 17500 & $\begin{array}{l}57 \\
50\end{array}$ & 280 & 410 & & DIED \\
\hline $\begin{array}{l}141 \\
161\end{array}$ & $\begin{array}{l}\begin{array}{l}3533 \\
3533\end{array} \\
35\end{array}$ & $M$ & $\begin{array}{l}\text { MOR TALITY } \\
\text { MORTALITY }\end{array}$ & $\begin{array}{l}239 \\
265\end{array}$ & $\begin{array}{l}18740 \\
18760\end{array}$ & $\begin{array}{l}59 \\
66\end{array}$ & $\begin{array}{l}290 \\
300\end{array}$ & $\begin{array}{l}4<0 \\
440\end{array}$ & $\begin{array}{l}290 \\
310\end{array}$ & $\begin{array}{l}\text { DIED } \\
\text { DIED }\end{array}$ \\
\hline 252 & 3534 & 19 & MORTALITY & 243 & 19430 & $\begin{array}{l}00 \\
58\end{array}$ & 310 & $\begin{array}{l}440 \\
450\end{array}$ & 310 & $\begin{array}{l}\text { DIED } \\
\text { DIED }\end{array}$ \\
\hline 241 & 3534 & $M$ & MORTALITY & 234 & 19600 & 65 & 313 & 460 & 32 & DIED \\
\hline 224 & 3534 & $\mathrm{~F}$ & MORTALITY & 140 & 19800 & 64 & 316 & 46 & & DIED \\
\hline 217 & 3534 & $F$ & MORTALITY & 143 & 20320 & 57 & 325 & 470 & 320 & DIED \\
\hline 157 & 3533 & it & MORTALITY & 263 & 20470 & 68 & 327 & 480 & 340 & DIED \\
\hline 253 & 3534 & M $>>>$ & MORTALITY & 236 & 20970 & 60 & 335 & 490 & 340 & DIED \\
\hline
\end{tabular}

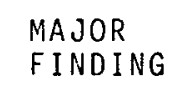

RAD_PNEUMONITIS

RAD-PNEUMONITIS

RAD-PNE UMONIT
RAD-PNEUMNII IS

RAD - PNEUMONITIS
RAD-PNEUMONITIS

RAD_PREMAONIIIS
RAD-PNUUNONITIS

RAD PNEUMONITIS

SQUAMMCELL CA

RAD PNEUMONITIS
RAD PNE UMONITIS

RADPPEUMONITIS
RAD PNEUMONITIS
RADPNEUMONITIS

RAD-PNEUMONITIS
RAD-PNEUMONITIS

RAD-PNEUMONITIS

RAD-PNEMONITIS
RAD-PNEUMONITIS

RAD-PNEUMONITIS

RAD-PNEUMONITIS
RAD-PNEUMONITIS

RAD-PNEUMONITIS

RAD PNEUMONITIS
RAD PNEUMONITIS

RAD PNEUMONITIS
RAD PNEUMONITIS

RAD PNEUMONITIS

RAD_PNEUMONITIS

RAD ${ }^{-}$PNEUMONIT IS

RAD-P PEUMONIIS
RADPNEUMONITS

RAD-PNEUMONITIS

RAD PNEUM GROSS
RAD-PNEUMONITIS

RAD-PNEUMONITIS

RAD-PNEUMONIT IS

RAD-PNEUMONITIS
RAD_PNEUMONITIS
OTHER FINDINGS AT DEATH

SEPT_FIBROSIS

SEPT_FIBROSIS

ADENO CARCINOMA

SEPT-FIBROSIS

SEPT_FIBROSIS

RAD_PNEUMONITIS

SEPT_FIBROSIS
SEPTFIBROSIS

SEPT_FIBROSIS

SEPT FIBROSIS

SEPT FIBROSIS
SEPT FIB

SEPT FIBROSIS

SEPT-FIBROSIS

SEPT FIBROSIS

SEPT FIBROSIS

SEPT FIBROSIS
SEPT FIBROSIS

SEPT-FBROSIS
SEPTEIBROSIS

SEPT_FIBROSIS

SEPT-FIBROSIS

SEPT FIBROSIS
SEPT FIBROSIS
SEPT FIBROSIS

SEPT_FIBROSIS

SEPIFIBROSIS

SEPT FIBROSI
SEPT FIBROSIS 
3D. PATHOLOGICAL OBSERVATIONS AND OTHER COMMENTS FOR RATS THAT DIED, WERE SACRIFICED OR EUTHANIZED AFTER INHALATION EXPOSURE TO Y9O-FAP

\begin{tabular}{|c|c|c|c|c|c|c|c|c|c|c|c|}
\hline $\begin{array}{l}\text { ANIMAL } \\
\text { NUMBER }\end{array}$ & $\begin{array}{l}\text { EXPERI- } \\
\text { MENT } \\
\text { NUMBER }\end{array}$ & SEX & GROUP & $\begin{array}{l}\text { INI I IAL } \\
\text { WEIGHT } \\
(g)\end{array}$ & $\begin{array}{c}\mathrm{ILB} \\
(\mathrm{kBq} / \mathrm{g} \\
\mathrm{LUNG})\end{array}$ & DPE & $\begin{array}{l}\text { 30-DAY } \\
\text { GRAYS }\end{array}$ & $\begin{array}{l}\text { 900-DAY } \\
\text { GRAYS }\end{array}$ & $\begin{array}{l}\text { GRAYS AT } \\
\text { DEATH }\end{array}$ & MODE C & OF DEATH \\
\hline 244 & 3534 & M & MORTALITY & 216 & 22640 & 60 & 362 & 530 & 360 & DIED & \\
\hline 257 & 3534 & M & MORTALITY & 246 & 22770 & 50 & 364 & 530 & 360 & DIED & \\
\hline 153 & 3533 & M & MORTALI TY & 250 & 23440 & 86 & 374 & 550 & 380 & OIED & \\
\hline 213 & 3534 & $F$ & MORTALITY & 134 & 23830 & 59 & $\begin{array}{l}381 \\
200\end{array}$ & 560 & 380 & DIED & \\
\hline $\begin{array}{l}225 \\
258\end{array}$ & $\begin{array}{l}3534 \\
3534\end{array}$ & $\mathrm{~F}$ & $\begin{array}{l}\text { MORTALI IYY } \\
\text { MORTAYY }\end{array}$ & $\begin{array}{l}112 \\
251\end{array}$ & $\begin{array}{l}24440 \\
25800\end{array}$ & $\begin{array}{l}72 \\
63\end{array}$ & $\begin{array}{l}390 \\
412\end{array}$ & $\begin{array}{l}570 \\
600\end{array}$ & 390 & $\begin{array}{l}\text { DIED } \\
\text { DIED }\end{array}$ & \\
\hline 251 & $\begin{array}{l}5354 \\
3534\end{array}$ & $\begin{array}{l}M \\
M\end{array}$ & $\begin{array}{l}\text { MORTALITY } \\
\text { MORTALI TY }\end{array}$ & $\begin{array}{l}251 \\
251\end{array}$ & $\begin{array}{l}25800 \\
26710\end{array}$ & $\begin{array}{l}63 \\
54\end{array}$ & $\begin{array}{l}412 \\
427\end{array}$ & $\begin{array}{l}800 \\
620\end{array}$ & 430 & DIED & \\
\hline $\begin{array}{l}251 \\
256\end{array}$ & $\begin{array}{l}3534 \\
3534\end{array}$ & $\begin{array}{l}M \\
M\end{array}$ & MORTALITY & 248 & 26840 & $\begin{array}{l}34 \\
54\end{array}$ & 429 & 630 & 450 & $\begin{array}{l}\text { DIED } \\
\text { DICU }\end{array}$ & \\
\hline 201 & 3534 & $\mathrm{~F}$ & PUL FUNCT & 150 & $200+0$ & 601 & 0 & 0 & 0 & SAC_E & EXXMINED \\
\hline 202 & 3534 & $\mathrm{~F}$ & PUL_FUNCT & 138 & 0 & 592 & 0 & 0 & 0 & DIED & \\
\hline 203 & 3534 & $F$ & PUL_FUNCT & 146 & 0 & 601 & 0 & 0 & 0 & SAC_E & EXAMINED \\
\hline 207 & $\begin{array}{l}3534 \\
3534\end{array}$ & $F$ & PUL-FUNCT & $\begin{array}{l}156 \\
286\end{array}$ & $\begin{array}{l}0 \\
0 \\
0\end{array}$ & $\begin{array}{l}601 \\
540\end{array}$ & $\begin{array}{l}0 \\
0\end{array}$ & 0 & 0 & $S^{S A C}$ & EXXAMI NED \\
\hline $\begin{array}{l}259 \\
261\end{array}$ & $\begin{array}{l}3534 \\
3534\end{array}$ & $M$ & $\begin{array}{l}\text { PUL FUNCT } \\
\text { PUULFUNCT }\end{array}$ & $\begin{array}{l}286 \\
282\end{array}$ & $\begin{array}{l}0 \\
0\end{array}$ & $\begin{array}{l}540 \\
540\end{array}$ & $\begin{array}{l}0 \\
0\end{array}$ & $\begin{array}{l}0 \\
0\end{array}$ & $\begin{array}{l}0 \\
0\end{array}$ & $\begin{array}{l}\text { ALIVE } \\
\text { ALIVE }\end{array}$ & $\begin{array}{l}\mathrm{VE} \\
\mathrm{VE}\end{array}$ \\
\hline $\begin{array}{l}267 \\
264\end{array}$ & $\begin{array}{l}3534 \\
3534\end{array}$ & $\begin{array}{l}M \\
M\end{array}$ & $\begin{array}{l}\text { PUL_FUNCC } \\
\text { PUL FUNCT }\end{array}$ & $\begin{array}{l}282 \\
297\end{array}$ & $\begin{array}{l}0 \\
0\end{array}$ & $\begin{array}{l}540 \\
540\end{array}$ & $\begin{array}{l}0 \\
0\end{array}$ & $\begin{array}{l}0 \\
0\end{array}$ & $\begin{array}{l}0 \\
0\end{array}$ & $\begin{array}{l}\text { ALIVE } \\
\text { ALIVE }\end{array}$ & \\
\hline $\begin{array}{l}264 \\
302\end{array}$ & $\begin{array}{r}3534 \\
3535\end{array}$ & $\frac{M}{F}$ & $\begin{array}{l}\text { PUL_FUNCT } \\
\text { PUL FUNCT }\end{array}$ & $\begin{array}{l}297 \\
141\end{array}$ & $\begin{array}{l}0 \\
0 \\
0\end{array}$ & $\begin{array}{l}540 \\
540\end{array}$ & 0 & 0 & $\begin{array}{l}0 \\
0\end{array}$ & $\begin{array}{l}\text { ALIVE } \\
\text { ALIVE }\end{array}$ & \\
\hline 304 & 3535 & $\mathrm{~F}$ & PUL_FUNCT & 156 & 0 & 540 & 0 & 0 & 0 & ALIVE & \\
\hline 359 & 3535 & M & PUL_FUNCT & 214 & 0 & 601 & 0 & 0 & 0 & SAC E & EXAMINED \\
\hline $\begin{array}{l}362 \\
262\end{array}$ & $\begin{array}{r}3535 \\
3255\end{array}$ & $M$ & PUL_FUNCT & 292 & 0 & 540 & 0 & 0 & 0 & $A L I \bar{V} E$ & $\overline{V E}$ \\
\hline $\begin{array}{l}363 \\
344\end{array}$ & $\begin{array}{r}3535 \\
3535\end{array}$ & $M$ & $\begin{array}{l}\text { PUL_FUNCT } \\
\text { PUI_FUNT }\end{array}$ & $\begin{array}{l}297 \\
250\end{array}$ & $\begin{array}{r}0 \\
1680\end{array}$ & $\begin{array}{l}601 \\
540\end{array}$ & $\begin{array}{r}0 \\
27\end{array}$ & 40 & 0 & ${ }_{\triangle A C}^{S A} \bar{E}$ & EXAMI NED \\
\hline $\begin{array}{l}344 \\
318\end{array}$ & $\begin{array}{l}3555 \\
3535\end{array}$ & $\begin{array}{l}M \\
F\end{array}$ & $\begin{array}{l}\text { PULLFUNNCT } \\
\text { PUL-FUNCCT }\end{array}$ & $\begin{array}{l}250 \\
156\end{array}$ & $\begin{array}{l}1680 \\
2850\end{array}$ & $\begin{array}{l}540 \\
708\end{array}$ & $\begin{array}{l}27 \\
45\end{array}$ & $\begin{array}{l}40 \\
70\end{array}$ & 60 & 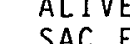 & VEE \\
\hline $\begin{array}{l}310 \\
315\end{array}$ & $\begin{array}{l}555 \\
3535\end{array}$ & $\mathrm{~F}$ & PUL-FUNCT & $\begin{array}{r}56 \\
154\end{array}$ & 2890 & $\begin{array}{l}608 \\
608\end{array}$ & 46 & 70 & 60 & 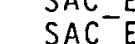 & $\begin{array}{l}\text { EXAMINEU } \\
\text { EXAMINED }\end{array}$ \\
\hline 345 & 3535 & M & PUL_FUNCT & $\begin{array}{l}248 \\
248\end{array}$ & $\begin{array}{l}2960 \\
2960\end{array}$ & $\begin{array}{l}608 \\
608\end{array}$ & 47 & 70 & 60 & $\mathrm{SAC}_{-}^{-}$ & EXAMINED \\
\hline 128 & 3533 & $\mathrm{~F}$ & PUL_FUNCT & 169 & 3650 & 609 & 58 & 90 & 70 & & EXAMI NED \\
\hline $\begin{array}{l}342 \\
130\end{array}$ & $\begin{array}{l}3535 \\
3533\end{array}$ & M & PUL FUNCT & 240 & $\begin{array}{l}3730 \\
3900\end{array}$ & 608 & 60 & 90 & $\begin{array}{l}70 \\
80\end{array}$ & $S^{S A C}-$ & EXAMINED \\
\hline 120 & $\begin{array}{l}3533 \\
3535\end{array}$ & F & PUL_FUNCT & 165 & 3900 & $\begin{array}{l}609 \\
572\end{array}$ & 62 & 90 & $\begin{array}{l}80 \\
90\end{array}$ & SAC- & EXAMI NED \\
\hline $\begin{array}{l}316 \\
125\end{array}$ & $\begin{array}{l}3555 \\
3533\end{array}$ & F & $\begin{array}{l}\text { PULLFUNCT } \\
\text { PULFUNCT }\end{array}$ & 171 & $\begin{array}{l}4500 \\
4450\end{array}$ & 6009 & 71 & $\begin{array}{l}100 \\
100\end{array}$ & 90 & 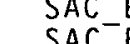 & $\begin{array}{l}\text { EXAMINED } \\
\text { EXAMIEFD }\end{array}$ \\
\hline $\begin{array}{l}125 \\
122\end{array}$ & 3533 & $\mathrm{~F}$ & PUL FUNCT & 165 & 460 & 609 & 74 & $\begin{array}{l}100 \\
110\end{array}$ & $\begin{array}{l}90 \\
90\end{array}$ & $\begin{array}{l}\text { SAC- } \\
\text { SAC }^{-1}\end{array}$ & 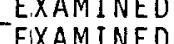 \\
\hline 317 & 3535 & $\mathrm{~F}$ & PUL FUNCT & 155 & 5230 & 608 & 83 & 120 & 100 & $S A C^{-}$ & $\begin{array}{l}\text { - EAMAMINED } \\
\text { EEAMED }\end{array}$ \\
\hline 113 & 3533 & $\mathrm{~F}$ & PUL ${ }^{-}$FUNCT & 156 & 5740 & 609 & 92 & 130 & 110 & $S_{S A} C^{-1}$ & EXAMINED \\
\hline 115 & 3533 & $\mathrm{~F}$ & PUL_FUNCT & 160 & 5800 & 609 & 93 & 140 & 110 & $\mathrm{SAC}_{-}^{-}$ & EXXMI I NED \\
\hline 154 & 3533 & M & PUL_FUNCT & 262 & 5880 & 609 & 94 & 140 & 120 & $S A C-1$ & EXAMINED \\
\hline 313 & $\begin{array}{r}3535 \\
2523\end{array}$ & $F$ & PUL_FUNCT & 757 & 5890 & 608 & 94 & 140 & 120 & $S A C-$ & EXAMINED \\
\hline $\begin{array}{l}142 \\
326\end{array}$ & $\begin{array}{l}3553 \\
3535\end{array}$ & $\mathrm{M}_{\mathrm{F}}$ & PUL F FUNCT & 240 & $\begin{array}{l}6170 \\
6650\end{array}$ & 609 & 99 & 140 & $\begin{array}{l}120 \\
130\end{array}$ & $\begin{array}{l}\text { SAC - } \\
\text { SAC }^{-}\end{array}$ & $\begin{array}{l}\text { EXAMINED } \\
\text { FXAMINED }\end{array}$ \\
\hline $\begin{array}{l}326 \\
102\end{array}$ & $\begin{array}{l}3535 \\
3533\end{array}$ & $\mathrm{~F}$ & PUL-FUNCT & $\begin{array}{l}164 \\
140\end{array}$ & $\begin{array}{l}6650 \\
6720\end{array}$ & $\begin{array}{l}608 \\
609\end{array}$ & $\begin{array}{l}106 \\
107\end{array}$ & $\begin{array}{l}160 \\
160\end{array}$ & $\begin{array}{l}130 \\
130\end{array}$ & $\begin{array}{l}\text { SAC- } \\
\text { SAC }\end{array}$ & EXAMINED \\
\hline 116 & 3533 & $\mathrm{~F}$ & PUL-FUNCT & $\begin{array}{l}150 \\
159\end{array}$ & 7370 & 609 & 118 & 170 & 150 & $S A C^{-}$ & EXAMINED \\
\hline 158 & 3533 & M & PUL_FUNCT & 265 & 7370 & 609 & 118 & 170 & 150 & $S A C_{-}^{-}$ & EXAMINED \\
\hline 127 & 3533 & $\mathrm{~F}$ & PUL_FUNCT & 163 & 7550 & 586 & 121 & 180 & 150 & EUTH & AAN I ZED \\
\hline 352 & 3535 & M & PULF FUNCT & 264 & 7620 & 608 & 122 & 180 & 150 & SAC & EXXXM I NED \\
\hline $\begin{array}{l}170 \\
353\end{array}$ & $\begin{array}{l}3533 \\
3525\end{array}$ & $M$ & PUL FUNCT & $\begin{array}{l}293 \\
258\end{array}$ & 7800 & 605 & $\begin{array}{l}125 \\
128\end{array}$ & 180 & 160 & DIED & \\
\hline $\begin{array}{l}353 \\
130\end{array}$ & $\begin{array}{l}\begin{array}{l}3535 \\
3533\end{array} \\
35\end{array}$ & M & $\begin{array}{l}\text { PULLFUNCT } \\
\text { PULFUNCT }\end{array}$ & $\begin{array}{l}258 \\
165\end{array}$ & $\begin{array}{l}8000 \\
8430\end{array}$ & $\begin{array}{l}608 \\
574\end{array}$ & $\begin{array}{l}128 \\
135\end{array}$ & $\begin{array}{l}190 \\
200\end{array}$ & $\begin{array}{l}60 \\
170\end{array}$ & SAC & EXAMINED \\
\hline $\begin{array}{l}130 \\
129\end{array}$ & 3533 & $\mathrm{~F}$ & PUL FUNCT & $\begin{array}{l}105 \\
167\end{array}$ & $\begin{array}{l}8430 \\
8870\end{array}$ & $\begin{array}{l}5 / 4 \\
563\end{array}$ & $\begin{array}{l}135 \\
142\end{array}$ & 210 & 180 & DIED & : ANI LEU \\
\hline 156 & 3533 & M & PUL_FUNCT & $\begin{array}{l}107 \\
263\end{array}$ & $\begin{array}{l}8810 \\
8930\end{array}$ & $\begin{array}{l}509 \\
609\end{array}$ & 143 & 210 & 180 & $\begin{array}{l}\text { SAC_ } \\
\text { SAE }\end{array}$ & \\
\hline 101 & 3533 & $\mathrm{~F}$ & $\begin{array}{l}\text { PUL_FUNCT } \\
\text { PUCT }\end{array}$ & 135 & 9050 & 609 & 145 & 210 & 180 & SAC- & EXAMINED \\
\hline $\begin{array}{l}343 \\
246\end{array}$ & $\begin{array}{l}3535 \\
3534\end{array}$ & $M$ & $\begin{array}{l}\text { PUL FUNCT } \\
\text { PUL FUUCT }\end{array}$ & $\begin{array}{l}236 \\
238\end{array}$ & $\begin{array}{l}9430 \\
9900\end{array}$ & $\begin{array}{l}608 \\
603\end{array}$ & $\begin{array}{l}151 \\
158\end{array}$ & $\begin{array}{l}220 \\
230\end{array}$ & $\begin{array}{l}190 \\
200\end{array}$ & $\begin{array}{l}S A C^{-} \\
D^{\prime}\end{array}$ & EXAMINED \\
\hline & & & & & & & & & & & \\
\hline
\end{tabular}

MAJOR
FINDING

RADPNEUMONITIS

RAD PNEUMONITIS
RAD-PNEUMONITIS

RAD-PNEUMONITIS

RAD-PNEUMONITIS

RAD-PNEUMONITIS

NO LESIONS
UREMIC PNEUMONIA

ALVEOLĀR HISTEO

SEPT-FIBROSIS

SEPT_FIBROSIS

NO LESIONS

ALVEOLAR_HISTEO

ALVEOLAR HISTEO

SEPT F F IBROSIS
ALVEOLAR HISTEO

NO LESIONS
RAD PNEUMONITIS

ALVEOLAR HISTEO

ALVEOLAR HISTEO

NO LESIOÑS

ALVEOLAR HISTEO

BA HYPER $\bar{P}$ LASIA

ALVEOLAR HISTEO SEPT $\bar{F} I B R O \bar{S}$ IS

ALVEŌLAR HISTEO
ALVEOLAR HISTEO

RAD PNEUMMONITIS

ALVẼOLAR HISTEO

NO LESIONS

RAD DNEUMONITIS

SQUĀM CELL CA

ALVEOLAR HISTEO

ALVEOLAR
SOUAM HISTEE
SELL CA

SEPT FIBROSIS
SEPT EIBROSIS

SEPT_FIBROSIS

BA_HYPERPLASIA

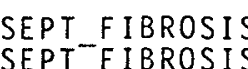
SEPT F FAROASIS

SEPT
OTHER FINDINGS AT DEAT

\section{SEPT FIIRROSIS
SEPT FIBRSIS
SEPT FIDROSIS}

ALVEOLAR HISTEO
SEPT_FIBROSIS, SQUAM_CELL_CA

SEPT-FIBROSIS

SEPT FIBROSIS: BA_HYPERPLASIA, LEUKEMIA

RAD PNEUMONITIS

SEPT_FIBROSIS, BA_HYPERPLASIA 


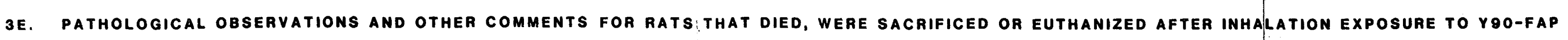

\begin{tabular}{|c|c|c|c|c|c|c|c|c|c|c|c|c|}
\hline $\begin{array}{l}\text { ANIMAL } \\
\text { NUBER R }\end{array}$ & $\begin{array}{l}\text { EXPERI- } \\
\text { MENT } \\
\text { NUMBER }\end{array}$ & SEX & GROUP & $\begin{array}{l}\text { INI I IAL } \\
\text { WEIGHT } \\
(\mathrm{g})\end{array}$ & $\begin{array}{c}I L B \\
(k B q / g \\
L U N G)\end{array}$ & DPE & $\begin{array}{l}30-D A Y \\
\text { GRAYS }\end{array}$ & $\begin{array}{l}900-D A Y \\
\text { GRAYS }\end{array}$ & $\begin{array}{l}\text { GRAYS AT } \\
\text { DEATH }\end{array}$ & MODE OF DEATH & $\begin{array}{l}\text { MAJOR } \\
\text { FINDING }\end{array}$ & OTHER FINDINGS AT DEATH \\
\hline $\begin{array}{l}160 \\
166 \\
165 \\
146 \\
151 \\
169\end{array}$ & $\begin{array}{l}3533 \\
3533 \\
3533 \\
3533 \\
3533 \\
3533\end{array}$ & $\begin{array}{l}M \\
M \\
M \\
M \\
M \\
M\end{array}$ & $\begin{array}{l}\text { PUL_FUNCT } \\
\text { PUL_FUNCT } \\
\text { PUL_FUNCT } \\
\text { PUL_FUNCT } \\
\text { PUL_FUNCT } \\
\text { PUL_FUNCT }\end{array}$ & $\begin{array}{l}266 \\
265 \\
272 \\
243 \\
263 \\
268\end{array}$ & $\begin{array}{l}10410 \\
10970 \\
10980 \\
11490 \\
12690 \\
14030\end{array}$ & $\begin{array}{l}609 \\
609 \\
575 \\
571 \\
609 \\
609\end{array}$ & $\begin{array}{l}166 \\
175 \\
175 \\
184 \\
203 \\
224\end{array}$ & $\begin{array}{l}240 \\
260 \\
260 \\
270 \\
300 \\
330\end{array}$ & $\begin{array}{l}210 \\
220 \\
220 \\
230 \\
250 \\
280\end{array}$ & $\begin{array}{l}\text { SAC_EXAMINED } \\
\text { SAC-EXAMINED } \\
\text { EUTHANIZED } \\
\text { SAC_EXMINED } \\
\text { SAC-EXAMINED } \\
\text { SAC-EXAMINED }\end{array}$ & $\begin{array}{l}\text { ALVEOLAR HISTEO } \\
\text { NOLESIONS } \\
\text { RAD PNEUMONITIS } \\
\text { ALVELAR_HISTEO } \\
\text { ALVEOLAR_HISTEO } \\
\text { ALVEOLAR_HISTEO }\end{array}$ & $\begin{array}{l}\text { SEPT_FIBROSIS, VASCULITIS } \\
\text { BA_HYPERPLASIA } \\
\text { SEPT_FIBRSIS, BA_HYPERPLASIA } \\
\text { SEPT-FIBROSIS, BA-HYPERPASIA } \\
\text { SEPT_FIBROSIS, ADENO_CARCINOMA }\end{array}$ \\
\hline
\end{tabular}


4A. PATHOLOGICAL OBSERVATIONS AND OTHER COMMENTS FOR RATS THAT DIED, WERE SACRIFICED OR EUTHANIZED AFTER INHALATION EXPOSURE TO SR9O AND Y9O IN FAP

\begin{tabular}{|c|c|c|c|}
\hline $\begin{array}{l}\text { ANIMAL } \\
\text { NUMBER }\end{array}$ & $\begin{array}{l}\text { EXPERI- } \\
\text { MENT } \\
\text { NUMBER }\end{array}$ & SEX & GROUP \\
\hline 431 & 3529 & $\mathrm{~F}$ & HEMATOLOGY \\
\hline $\begin{array}{l}432 \\
433\end{array}$ & $\begin{array}{l}3529 \\
3520\end{array}$ & $\mathrm{~F}$ & HEMATOLOGY \\
\hline $\begin{array}{l}433 \\
435\end{array}$ & $\begin{array}{l}3529 \\
3529\end{array}$ & $\underset{\mathrm{F}}{\mathrm{F}}$ & $\begin{array}{l}\text { HEMATOLOGY } \\
\text { HEMATOLOGY }\end{array}$ \\
\hline 436 & 3529 & M & HEMATOLOGY \\
\hline $\begin{array}{l}437 \\
438\end{array}$ & $\begin{array}{l}3529 \\
3529\end{array}$ & M & HEMATOLOGY \\
\hline $\begin{array}{l}438 \\
439\end{array}$ & $\begin{array}{l}3529 \\
3529\end{array}$ & $M$ & $\begin{array}{l}\text { HEMATOLOGY } \\
\text { HEATOLOGY }\end{array}$ \\
\hline $\begin{array}{l}439 \\
440\end{array}$ & $\begin{array}{l}3529 \\
3529\end{array}$ & M & \\
\hline 332 & 3528 & $\mathrm{~F}$ & $\begin{array}{l}\text { HEMAOLLOGY } \\
\text { HEMATOLOGY }\end{array}$ \\
\hline & $\begin{array}{l}3528 \\
2528\end{array}$ & & HEMATOLOGY \\
\hline 338 & 3528 & M & HEMATOLOGY \\
\hline $\begin{array}{l}337 \\
333\end{array}$ & $\begin{array}{l}3528 \\
2528\end{array}$ & M & HEMATOLOGY \\
\hline $\begin{array}{l}333 \\
331\end{array}$ & $\begin{array}{l}3528 \\
3528\end{array}$ & $F$ & HEMATOLOGY \\
\hline $\begin{array}{l}331 \\
335\end{array}$ & $\begin{array}{l}\begin{array}{r}3528 \\
3528\end{array} \\
352\end{array}$ & ${ }_{F}^{F}$ & $\begin{array}{l}\text { HEMATOLOGY } \\
\text { HEATOLOGY }\end{array}$ \\
\hline 334 & 3528 & $\mathrm{~F}$ & $\begin{array}{l}\text { HEEATOLOGY } \\
\text { HEMATOLOGY }\end{array}$ \\
\hline 233 & 3527 & $\mathrm{~F}$ & HEMATOLOGY \\
\hline $\begin{array}{l}240 \\
235\end{array}$ & $\begin{array}{l}3527 \\
3527\end{array}$ & $M_{F}^{M}$ & HEMATOLOGY \\
\hline $\begin{array}{l}235 \\
336\end{array}$ & $\begin{array}{l}\begin{array}{l}3527 \\
3528\end{array} \\
\end{array}$ & F & HEMATOLOGY \\
\hline 133 & $\begin{array}{l}3526 \\
3526\end{array}$ & $\mathrm{~F}$ & $\begin{array}{l}\text { HEFATOLOGY } \\
\text { HEATOLOGY }\end{array}$ \\
\hline 232 & 3527 & $\mathrm{~F}$ & HEMATOLOGY \\
\hline 236 & 3527 & M & HEMATOLOGY \\
\hline 132 & $\begin{array}{l}3526 \\
2526\end{array}$ & F & HEMATOLOGY \\
\hline 140 & $\begin{array}{l}3526 \\
2528\end{array}$ & $M$ & $\begin{array}{l}\text { HEMATOLOGY } \\
\text { HEMATOL }\end{array}$ \\
\hline $\begin{array}{l}340 \\
238\end{array}$ & $\begin{array}{l}3528 \\
3527\end{array}$ & $M$ & $\begin{array}{l}\text { HEMATOLOGY } \\
\text { HEMATOLOGY }\end{array}$ \\
\hline 234 & 3527 & $F$ & HEMATOLOGY \\
\hline $\begin{array}{l}135 \\
139\end{array}$ & $\begin{array}{l}3526 \\
3526\end{array}$ & F & HEMATOLOGY \\
\hline $\begin{array}{l}139 \\
137\end{array}$ & $\begin{array}{l}\begin{array}{l}3526 \\
3526\end{array} \\
352\end{array}$ & $M$ & $\begin{array}{l}\text { HEMATOLOGY } \\
\text { HEMATOLOGG }\end{array}$ \\
\hline & $\begin{array}{l}3520 \\
3527\end{array}$ & $M$ & HEMA OLOLGY \\
\hline 131 & 3526 & $\mathrm{~F}$ & HEMATOLOGY \\
\hline & 3527 & $\mathrm{~F}$ & HEMATOLOGY \\
\hline 138 & 3526 & M & HEMATOLLOG \\
\hline 134 & $\begin{array}{l}3526 \\
2520\end{array}$ & F & HEMATOLOGY \\
\hline & $\begin{array}{l}3529 \\
3529\end{array}$ & F & $\begin{array}{l}\text { MORTALITY } \\
\text { MORTA IY }\end{array}$ \\
\hline $\begin{array}{l}402 \\
403\end{array}$ & $\begin{array}{l}3529 \\
3529\end{array}$ & $\mathrm{~F}$ & $\begin{array}{l}\text { MORTALL ITY } \\
\text { MORTALITY }\end{array}$ \\
\hline 404 & 3529 & $\mathrm{~F}$ & MORTALITY \\
\hline 405 & 3529 & $\mathrm{~F}$ & MORALI TY \\
\hline 406 & $\begin{array}{l}3529 \\
3520\end{array}$ & $F$ & MORTALITY \\
\hline 407 & 3529 & $\mathrm{~F}$ & MORTALITY \\
\hline 408 & 3529 & $F$ & MORTAL I TY \\
\hline 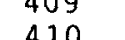 & $\begin{array}{l}35<9 \\
2530\end{array}$ & $\mathrm{~F}$ & MORTALITY \\
\hline 411 & 3529 & $\mathrm{~F}$ & MORTALI IY \\
\hline $\begin{array}{l}412 \\
413\end{array}$ & $\begin{array}{l}3529 \\
3520\end{array}$ & $\mathrm{~F}$ & MORTAL ITY \\
\hline 413 & & & MORTALITY \\
\hline
\end{tabular}

\begin{tabular}{|c|c|c|c|}
\hline $\begin{array}{l}\text { INITIALI IAI } \\
\text { WEIGHT } \\
(\mathrm{g})\end{array}$ & $\begin{array}{c}\mathrm{ILB} \\
(\mathrm{kBq} / \mathrm{g} \\
\mathrm{LUNG}\end{array}$ & DPE & $\begin{array}{l}30-D A Y \\
\text { GRAYS }\end{array}$ \\
\hline & & $\overline{540}$ & 0 \\
\hline 175 & $\begin{array}{l}0 \\
0\end{array}$ & $\begin{array}{l}540 \\
540\end{array}$ & $\begin{array}{l}0 \\
0\end{array}$ \\
\hline $\begin{array}{l}178 \\
183\end{array}$ & $\begin{array}{l}0 \\
0\end{array}$ & $\begin{array}{l}540 \\
565\end{array}$ & $\begin{array}{l}0 \\
0\end{array}$ \\
\hline 230 & $\begin{array}{l}0 \\
0\end{array}$ & 540 & $\begin{array}{l}0 \\
0\end{array}$ \\
\hline 247 & $\begin{array}{l}0 \\
0\end{array}$ & 540 & 0 \\
\hline $\begin{array}{l}246 \\
259\end{array}$ & $\begin{array}{l}0 \\
0\end{array}$ & $\begin{array}{l}540 \\
54\end{array}$ & $\begin{array}{l}0 \\
0\end{array}$ \\
\hline 261 & 0 & $\begin{array}{l}340 \\
629\end{array}$ & 0 \\
\hline 172 & 160 & 540 & 5 \\
\hline $\begin{array}{l}261 \\
235\end{array}$ & $\begin{array}{l}210 \\
230\end{array}$ & $\begin{array}{l}540 \\
540\end{array}$ & $\begin{array}{l}6 \\
6 \\
6\end{array}$ \\
\hline 237 & 270 & 540 & $\begin{array}{l}6 \\
7\end{array}$ \\
\hline 174 & 410 & 540 & 11 \\
\hline $\begin{array}{l}182 \\
185\end{array}$ & $\begin{array}{l}450 \\
550 \\
550\end{array}$ & $\begin{array}{l}540 \\
540\end{array}$ & 13 \\
\hline $\begin{array}{l}185 \\
177\end{array}$ & $\begin{array}{l}550 \\
580\end{array}$ & $\begin{array}{l}540 \\
540\end{array}$ & $\begin{array}{l}15 \\
16\end{array}$ \\
\hline 174 & 740 & 540 & $\begin{array}{l}16 \\
21\end{array}$ \\
\hline 260 & 760 & 540 & 21 \\
\hline 140 & 840 & 630 & 23 \\
\hline 219 & 900 & 629 & 25 \\
\hline 178 & 940 & 630 & 26 \\
\hline $\begin{array}{r}115 \\
218\end{array}$ & $\begin{array}{l}1150 \\
1170\end{array}$ & $\begin{array}{l}515 \\
510\end{array}$ & $\begin{array}{l}32 \\
33\end{array}$ \\
\hline 169 & 1300 & $\begin{array}{l}540 \\
530\end{array}$ & $\begin{array}{l}33 \\
36\end{array}$ \\
\hline 240 & 1330 & $\begin{array}{l}530 \\
540\end{array}$ & $\begin{array}{l}66 \\
37\end{array}$ \\
\hline 232 & 1350 & 540 & 38 \\
\hline 257 & 1450 & 540 & 40 \\
\hline 180 & $\begin{array}{l}1570 \\
570\end{array}$ & 540 & 44 \\
\hline 184 & & $\begin{array}{l}540 \\
568\end{array}$ & 45 \\
\hline $\begin{array}{l}256 \\
250\end{array}$ & $\begin{array}{l}2610 \\
201\end{array}$ & $\begin{array}{l}508 \\
575\end{array}$ & $\begin{array}{l}63 \\
73\end{array}$ \\
\hline 250 & 3440 & $\begin{array}{r}459 \\
110\end{array}$ & 96 \\
\hline 174 & $\begin{array}{l}3650 \\
\end{array}$ & $\begin{array}{l}119 \\
176\end{array}$ & 102 \\
\hline 112 & $\begin{array}{l}4330 \\
5230\end{array}$ & $\begin{array}{l}116 \\
561\end{array}$ & $\begin{array}{l}121 \\
146\end{array}$ \\
\hline 175 & $\begin{array}{l}530 \\
64\end{array}$ & $\begin{array}{l}501 \\
263\end{array}$ & $\begin{array}{l}466 \\
181\end{array}$ \\
\hline 135 & 0 & 540 & 0 \\
\hline 138 & 0 & 540 & 0 \\
\hline 149 & 0 & 540 & 0 \\
\hline $\begin{array}{l}151 \\
145\end{array}$ & $\begin{array}{l}0 \\
0\end{array}$ & $\begin{array}{l}540 \\
241\end{array}$ & 0 \\
\hline 151 & 0 & 540 & 0 \\
\hline $\begin{array}{l}155 \\
155\end{array}$ & 0 & 540 & 0 \\
\hline 151 & 0 & 540 & 0 \\
\hline 101 & 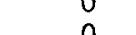 & 540 & $\begin{array}{l}0 \\
0\end{array}$ \\
\hline 163 & 0 & 540 & 0 \\
\hline 153 & n & 540 & 0 \\
\hline & & & \\
\hline
\end{tabular}

\begin{tabular}{|c|c|c|c|}
\hline $\begin{array}{l}900-D A Y \\
\text { GRAYS }\end{array}$ & $\begin{array}{l}\text { GRAYS AT } \\
\text { DEATH }\end{array}$ & MODE $\mid \mathrm{C}$ & OF DEATH \\
\hline 0 & 0 & ALIVE & \\
\hline $\begin{array}{l}0 \\
0\end{array}$ & $\begin{array}{l}0 \\
0\end{array}$ & ALIVE & \\
\hline $\begin{array}{l}0 \\
0 \\
0\end{array}$ & $\begin{array}{l}0 \\
0\end{array}$ & $\begin{array}{l}\text { ALIVE } \\
\text { EUTHA }\end{array}$ & AANIZED \\
\hline 0 & 0 & ALIV & \\
\hline $\begin{array}{l}0 \\
0\end{array}$ & $\begin{array}{l}0 \\
0\end{array}$ & ALIYE & \\
\hline 0 & 0 & ALIVE & \\
\hline $\begin{array}{r}0 \\
10\end{array}$ & 0 & $\begin{array}{l}\text { SACIE } \\
\text { ALIE: }\end{array}$ & EXAMINED \\
\hline 20 & & ALIVE & \\
\hline $\begin{array}{l}20 \\
20\end{array}$ & & $\begin{array}{l}\text { ALIVE } \\
\text { ALIVE }\end{array}$ & \\
\hline 40 & & ALIY & \\
\hline $\begin{array}{l}40 \\
50\end{array}$ & & ALIVE & \\
\hline 50 & & ALIVE & \\
\hline 70 & & ALIVE & \\
\hline 80 & 70 & $\begin{array}{l}\text { ALIVE } \\
\text { SAC }\end{array}$ & EXAMINED \\
\hline 80 & 80 & $S A C^{-}$ & EXAMINED \\
\hline $\begin{array}{r}80 \\
100\end{array}$ & $\begin{array}{l}80 \\
100\end{array}$ & $\begin{array}{l}\text { SACIE } \\
\text { DIEE }\end{array}$ & EXAMINED \\
\hline $\begin{array}{l}110 \\
120\end{array}$ & 110 & ALIV & E \\
\hline 120 & & $\begin{array}{l}\text { AUIHE } \\
\text { ALIVE }\end{array}$ & \\
\hline $\begin{array}{l}120 \\
130\end{array}$ & & $\begin{array}{l}\text { ALIVE } \\
\text { ALIVE }\end{array}$ & \\
\hline 140 & & ALIVE & \\
\hline 140 & & ALIVE & \\
\hline 200 & $\begin{array}{l}200 \\
230\end{array}$ & DIEQ & \\
\hline 310 & 280 & $\begin{array}{l}\text { DIED } \\
\text { DIED }\end{array}$ & \\
\hline 330 & 190 & DIED & \\
\hline $\begin{array}{l}390 \\
370\end{array}$ & $\begin{array}{l}270 \\
150\end{array}$ & $\begin{array}{l}01 E 0 \\
01 E\end{array}$ & \\
\hline 580 & $\begin{array}{l}450 \\
470\end{array}$ & $\begin{array}{l}\text { DIED } \\
\text { DIED }\end{array}$ & \\
\hline 0 & 0 & ALIVE & \\
\hline 0 & $\begin{array}{l}0 \\
0 \\
0\end{array}$ & & \\
\hline $\begin{array}{l}\sigma_{0} \\
0\end{array}$ & 0 & & \\
\hline 0 & 0 & & HANIZEO \\
\hline 0 & 0 & & \\
\hline 0 & 0 & ALIVE & \\
\hline $\begin{array}{l}0 \\
0\end{array}$ & $\begin{array}{l}0 \\
0\end{array}$ & $\begin{array}{l}\text { ALIVE } \\
\text { ALIVE }\end{array}$ & \\
\hline 0 & 0 & ALIVE & \\
\hline 0 & 0 & ALIVE & \\
\hline $\begin{array}{l}0 \\
0 \\
0\end{array}$ & $\begin{array}{l}0 \\
0 \\
0\end{array}$ & $\begin{array}{l}\text { ALIVE } \\
\text { ALIVE }\end{array}$ & VE \\
\hline
\end{tabular}

MAJOR
FINDING

NO_LESIONS

BA HYPERPLASIA BA HYPERPLASIA
ALVEOLAR HISTEO
RAD PNEUMONITIS

SQUAM_CELL_CA

ADENO CACARCINOMA

RAD_PNEUMONITIS

RAD-PNEUMONITIS
RAD PNEUMONITIS

SQUAM CELL CA
RAD PNEUMONIIIS

ALVEOLAR_HISTEO
SEPT_FIBROSIS

OTHER FINDINGS AT DEATH

RAD PNEUMONITIS

SEPT_FIBROSIS

RAD PNEUMONITIS, SEPT_FIBROSIS

SEPT_FIBROSIS 


\begin{tabular}{|c|c|c|c|c|c|c|c|c|c|c|}
\hline $\begin{array}{l}\text { ANIMLL } \\
\text { NUMBER }\end{array}$ & $\begin{array}{l}\text { EXPERI- } \\
\text { MENT } \\
\text { NUMEER }\end{array}$ & SEX & GROUP & $\begin{array}{l}\text { NIIIAL } \\
\text { WEIGHT } \\
(\mathrm{g})\end{array}$ & 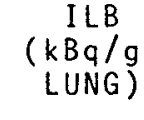 & DPE & $\begin{array}{l}\text { SODAY } \\
\text { GRAYS }\end{array}$ & $\begin{array}{l}900-\text { DAY } \\
\text { GRAYS }\end{array}$ & $\begin{array}{l}\text { GRAYS AT } \\
\text { DEATH }\end{array}$ & MODE OF DEATH \\
\hline 414 & $\begin{array}{l}3529 \\
2520\end{array}$ & $\mathrm{~F}$ & MORTALI IY & 154 & 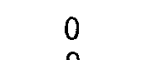 & 540 & 0 & 0 & 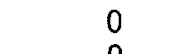 & ALIVE \\
\hline $\begin{array}{l}415 \\
416\end{array}$ & $\begin{array}{l}3529 \\
3529 \\
3520\end{array}$ & F & $\begin{array}{l}\text { MORTALI ITY } \\
\text { MORTLITY }\end{array}$ & $\begin{array}{l}158 \\
167\end{array}$ & 0 & $\begin{array}{l}540 \\
540\end{array}$ & 0 & 0 & $\begin{array}{l}0 \\
0\end{array}$ & $\begin{array}{l}\text { ALIVE } \\
\text { ALIVE }\end{array}$ \\
\hline $\begin{array}{l}418 \\
418\end{array}$ & $\begin{array}{l}3529 \\
3520 \\
2520\end{array}$ & $\stackrel{F}{F}$ & MORTALITY & $\begin{array}{l}170 \\
170\end{array}$ & 0 & $\begin{array}{l}540 \\
540 \\
620\end{array}$ & $\begin{array}{l}0 \\
0\end{array}$ & $\begin{array}{l}0 \\
0 \\
0\end{array}$ & $\begin{array}{l}0 \\
0 \\
0\end{array}$ & $\begin{array}{l}\text { ALIE } \\
\text { ALI IE } \\
\text { SAC }\end{array}$ \\
\hline $4<0$ & $\begin{array}{l}3529 \\
3529 \\
3\end{array}$ & 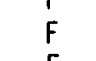 & MORTALITY & 172 & 0 & 629 & 0 & 0 & 0 & $\begin{array}{l}\text { SAC-EAC } \\
\text { SAEAMINED }\end{array}$ \\
\hline $\begin{array}{l}422 \\
423\end{array}$ & $\begin{array}{l}3529 \\
3529\end{array}$ & $\stackrel{\mathrm{F}}{\mathrm{F}}$ & $\begin{array}{l}\text { MOOTALLIYY } \\
\text { MORTALIYY }\end{array}$ & $\begin{array}{l}168 \\
158 \\
158 \\
-1\end{array}$ & $\begin{array}{l}0 \\
0\end{array}$ & $\begin{array}{l}629 \\
540\end{array}$ & 0 & $\begin{array}{l}0 \\
0\end{array}$ & $\begin{array}{l}0 \\
0\end{array}$ & $\begin{array}{l}\text { SAC-EXMINED } \\
\text { ALIVEE }\end{array}$ \\
\hline $\begin{array}{l}424 \\
425\end{array}$ & $\begin{array}{l}3529 \\
3529\end{array}$ & 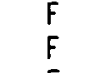 & $\begin{array}{l}\text { MOORTALLIY } \\
\text { MORTALITY }\end{array}$ & $\begin{array}{l}160 \\
167\end{array}$ & $\begin{array}{l}0 \\
0\end{array}$ & $\begin{array}{l}499 \\
539 \\
-\end{array}$ & 0 & $\begin{array}{l}0 \\
0\end{array}$ & $\begin{array}{l}0 \\
0 \\
0\end{array}$ & $\begin{array}{l}\text { DIED } \\
\text { DIED }\end{array}$ \\
\hline $\begin{array}{l}427 \\
427\end{array}$ & 3529 & $F$ & MORTALITY & $\begin{array}{l}101 \\
172 \\
172\end{array}$ & 0 & 540 & 0 & 0 & 0 & $\begin{array}{l}\text { ALIVE } \\
\text { ALIVE }\end{array}$ \\
\hline 429 & $\begin{array}{l}3529 \\
3520\end{array}$ & F & MORTALITY & 173 & 0 & $\begin{array}{l}540 \\
208 \\
500\end{array}$ & 0 & 0 & 0 & 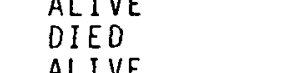 \\
\hline $\begin{array}{l}450 \\
447\end{array}$ & $\begin{array}{l}3529 \\
3529\end{array}$ & M & $\begin{array}{l}\text { MORTALITY } \\
\text { MORTALY }\end{array}$ & $\begin{array}{l}269 \\
265 \\
255\end{array}$ & 0 & $\begin{array}{l}340 \\
629 \\
620\end{array}$ & 0 & 0 & 0 & $\begin{array}{l}\text { SAC-EXMINED } \\
\text { SAC EXAMIEF }\end{array}$ \\
\hline $\begin{array}{l}443 \\
444\end{array}$ & $\begin{array}{l}3529 \\
3529\end{array}$ & M & $\begin{array}{l}\text { MORALITY } \\
\text { MORTALITY }\end{array}$ & $\begin{array}{l}285 \\
277\end{array}$ & $\begin{array}{l}0 \\
0 \\
0\end{array}$ & $\begin{array}{l}540 \\
540\end{array}$ & $\begin{array}{l}0 \\
0 \\
0\end{array}$ & $\begin{array}{c}0 \\
0 \\
0\end{array}$ & $\begin{array}{l}0 \\
0\end{array}$ & $\begin{array}{l}\text { ALIVE } \\
\text { ALIVE }\end{array}$ \\
\hline $\begin{array}{l}445 \\
446\end{array}$ & $\begin{array}{l}\begin{array}{l}3529 \\
3529\end{array} \\
35\end{array}$ & $\underset{M}{M}$ & $\begin{array}{l}\text { MOOTALITY } \\
\text { MORTALITY }\end{array}$ & $\begin{array}{l}279 \\
256 \\
256\end{array}$ & $\begin{array}{l}0 \\
0\end{array}$ & $\begin{array}{l}540 \\
540\end{array}$ & $\begin{array}{l}0 \\
0\end{array}$ & $\begin{array}{l}0 \\
0\end{array}$ & $\begin{array}{l}0 \\
0\end{array}$ & $\begin{array}{l}\text { ALIVE } \\
\text { ALIVE }\end{array}$ \\
\hline $\begin{array}{l}447 \\
448\end{array}$ & $\begin{array}{l}3529 \\
3529 \\
\end{array}$ & $M$ & $\begin{array}{l}\text { MOOTALLTY } \\
\text { MORTALITY }\end{array}$ & $\begin{array}{l}268 \\
269\end{array}$ & $\begin{array}{l}0 \\
0\end{array}$ & $\begin{array}{l}540 \\
540\end{array}$ & $\begin{array}{l}0 \\
0\end{array}$ & $\begin{array}{l}0 \\
0\end{array}$ & $\begin{array}{l}0 \\
0\end{array}$ & $\begin{array}{l}\text { ALIVE } \\
\text { ALIVE }\end{array}$ \\
\hline $\begin{array}{l}449 \\
450\end{array}$ & $\begin{array}{l}3529 \\
3520\end{array}$ & $M$ & MORTALITY & 年 254 & $\begin{array}{l}0 \\
0 \\
0\end{array}$ & $\begin{array}{l}540 \\
540 \\
540\end{array}$ & $\begin{array}{l}0 \\
0 \\
0\end{array}$ & $\begin{array}{l}0 \\
0 \\
0\end{array}$ & $\begin{array}{l}0 \\
0 \\
0\end{array}$ & $\begin{array}{l}\text { ALIVE } \\
\text { ALIVE }\end{array}$ \\
\hline $\begin{array}{l}451 \\
452 \\
452\end{array}$ & $\begin{array}{l}3529 \\
3529 \\
3529\end{array}$ & $\stackrel{M}{M}$ & $\begin{array}{l}\text { MoOTALITY } \\
\text { MORTALITY }\end{array}$ & $\begin{array}{l}255 \\
282 \\
282\end{array}$ & $\begin{array}{l}0 \\
0\end{array}$ & $\begin{array}{l}540 \\
540\end{array}$ & $\begin{array}{l}0 \\
0 \\
0\end{array}$ & $\begin{array}{l}0 \\
0 \\
0\end{array}$ & $\begin{array}{l}0 \\
0\end{array}$ & $\begin{array}{l}\text { AAIVE } \\
\text { ALIVE }\end{array}$ \\
\hline $\begin{array}{l}453 \\
454 \\
456\end{array}$ & $\begin{array}{l}3529 \\
3529 \\
3520\end{array}$ & M & MORTALITY & 年 & 0 & $\begin{array}{l}540 \\
540 \\
527\end{array}$ & $\begin{array}{l}0 \\
0\end{array}$ & $\begin{array}{l}0 \\
0 \\
0\end{array}$ & $\begin{array}{l}0 \\
0 \\
0\end{array}$ & 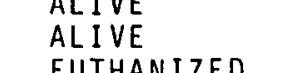 \\
\hline $\begin{array}{l}457 \\
458\end{array}$ & $\begin{array}{l}3529 \\
3529 \\
3520\end{array}$ & M & $\begin{array}{l}\text { MORTALITY } \\
\text { MOTSTITY }\end{array}$ & $\begin{array}{l}290 \\
290 \\
285\end{array}$ & $\begin{array}{l}0 \\
0 \\
0\end{array}$ & $\begin{array}{l}540 \\
540\end{array}$ & 0 & 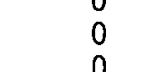 & 0 & 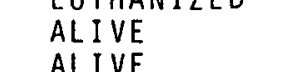 \\
\hline $\begin{array}{l}459 \\
460 \\
460\end{array}$ & $\begin{array}{l}3529 \\
3529 \\
352\end{array}$ & $\stackrel{M}{M}$ & $\begin{array}{l}\text { MORTALITY } \\
\text { MRTAIITY }\end{array}$ & $\begin{array}{l}268 \\
275 \\
275\end{array}$ & $\begin{array}{l}0 \\
0 \\
0\end{array}$ & $\begin{array}{l}540 \\
540\end{array}$ & 0 & $\begin{array}{l}0 \\
0\end{array}$ & $\begin{array}{l}0 \\
0 \\
0\end{array}$ & $\begin{array}{l}\text { ALIVE } \\
\text { ALIVE }\end{array}$ \\
\hline $\begin{array}{l}461 \\
462 \\
4\end{array}$ & $\begin{array}{l}\begin{array}{l}3529 \\
3529\end{array} \\
3529\end{array}$ & ${ }_{M}^{M}$ & $\begin{array}{l}\text { MOOTALLITY } \\
\text { MORTALITY }\end{array}$ & $\begin{array}{l}302 \\
289\end{array}$ & $\begin{array}{l}0 \\
0\end{array}$ & $\begin{array}{l}540 \\
540\end{array}$ & 0 & $\begin{array}{l}0 \\
0\end{array}$ & $\begin{array}{l}0 \\
0\end{array}$ & $\begin{array}{l}\text { ALIVE } \\
\text { ALIVE }\end{array}$ \\
\hline $\begin{array}{l}463 \\
464\end{array}$ & $\begin{array}{l}\begin{array}{l}3529 \\
3529\end{array} \\
3529\end{array}$ & ${ }_{M}^{M}$ & $\begin{array}{l}\text { MOOTALLITY } \\
\text { MORTALITY }\end{array}$ & $\begin{array}{l}260 \\
277\end{array}$ & $\begin{array}{l}0 \\
0\end{array}$ & $\begin{array}{l}540 \\
645\end{array}$ & 0 & $\begin{array}{l}0 \\
0\end{array}$ & $\begin{array}{l}0 \\
0 \\
0\end{array}$ & $\begin{array}{l}\text { AAIVE } \\
\text { DIED }\end{array}$ \\
\hline $\begin{array}{l}466 \\
467 \\
467\end{array}$ & $\begin{array}{l}3529 \\
3529\end{array}$ & M & $\begin{array}{l}\text { MOLTALIYY } \\
\text { MORTALY }\end{array}$ & $\begin{array}{l}306 \\
306 \\
300\end{array}$ & 0 & $\begin{array}{l}540 \\
540\end{array}$ & 0 & 0 & $\begin{array}{l}0 \\
0 \\
0\end{array}$ & $\begin{array}{l}\text { AAIVE } \\
\text { ALIVE }\end{array}$ \\
\hline 01 & $\begin{array}{l}3529 \\
3520\end{array}$ & M & MORTALITY & $\begin{array}{l}313 \\
322 \\
222\end{array}$ & 0 & $\begin{array}{l}540 \\
540 \\
540\end{array}$ & 0 & 0 & $\begin{array}{l}0 \\
0\end{array}$ & $\begin{array}{l}\text { ALIVE } \\
\text { ALIVE }\end{array}$ \\
\hline 470 & $\begin{array}{l}3529 \\
3528 \\
3\end{array}$ & M & $\begin{array}{l}\text { MORTALY } \\
\text { MOT TY }\end{array}$ & $\begin{array}{l}398 \\
202 \\
202\end{array}$ & o & $\begin{array}{l}340 \\
640 \\
540\end{array}$ & 0 & 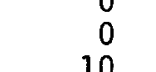 & 0 & $\begin{array}{l}\text { DLE } \\
\text { DIED } \\
\text { D. }\end{array}$ \\
\hline $\begin{array}{l}350 \\
370\end{array}$ & $\begin{array}{l}3528 \\
3528 \\
2528\end{array}$ & 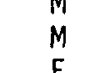 & $\begin{array}{l}\text { MOT TALTY } \\
\text { MOT }\end{array}$ & $\begin{array}{l}293 \\
323 \\
162\end{array}$ & 120 & $\begin{array}{l}540 \\
540 \\
540\end{array}$ & & 10 & & $\begin{array}{l}\text { ALIVE } \\
\text { ALIVE }\end{array}$ \\
\hline & $\begin{array}{l}3528 \\
3527\end{array}$ & & MORTALITY & 174 & 160 & $\begin{array}{l}540 \\
540 \\
540\end{array}$ & & $\begin{array}{l}10 \\
10\end{array}$ & & $\begin{array}{l}\text { ALIVE } \\
\text { ALIVVE }\end{array}$ \\
\hline
\end{tabular}
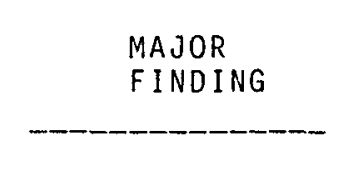

\section{NO-LES IONS
NO-LESIONS
NO-LESIONS}

LEUKEMIA

CONGESTION

NOLLESIONS
NO-LESIONS

NO_LESIONS

CONGESTION

LEUKEMIA
OTHER FINDINGS AT DEATH

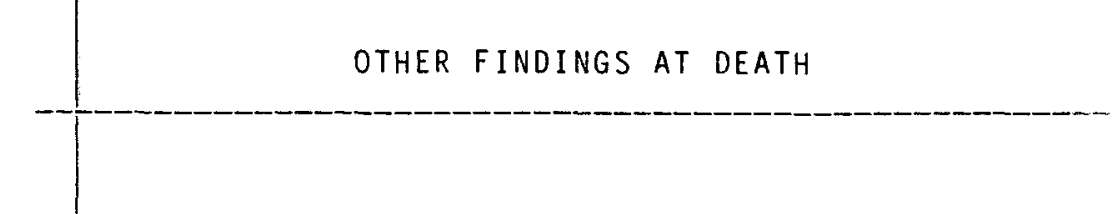




\begin{tabular}{|c|c|c|c|c|c|c|c|c|}
\hline $\begin{array}{l}\text { ANIMAL } \\
\text { NUMBER }\end{array}$ & $\begin{array}{l}\text { EXPERI- } \\
\text { MENT } \\
\text { NUMBER }\end{array}$ & SEX & GROUP & $\begin{array}{l}\text { IN I I IAL } \\
\text { WE IGHT } \\
(g)\end{array}$ & $\begin{array}{c}\text { ILB } \\
(k B q / g \\
L U N G)\end{array}$ & DPE & $\begin{array}{l}\text { 30-DAY } \\
\text { GRAYS }\end{array}$ & $\begin{array}{l}\text { 900-DAY } \\
\text { GRAYS }\end{array}$ \\
\hline 342 & 3528 & M & MORTALITY & 265 & 180 & 380 & 5 & 20 \\
\hline 328 & $\begin{array}{l}3528 \\
3528\end{array}$ & F & MORTALITY & $\begin{array}{l}165 \\
265\end{array}$ & 200 & 540 & 6 & 20 \\
\hline $\begin{array}{l}354 \\
209\end{array}$ & $\begin{array}{l}3528 \\
3527\end{array}$ & $\begin{array}{l}M \\
F\end{array}$ & MORTALITY & $\begin{array}{l}265 \\
160\end{array}$ & $\begin{array}{l}210 \\
220\end{array}$ & $\begin{array}{l}540 \\
540\end{array}$ & $\begin{array}{l}6 \\
6\end{array}$ & $\begin{array}{l}20 \\
20\end{array}$ \\
\hline 212 & 3527 & $\mathrm{~F}$ & MORTALITY & 151 & & $\begin{array}{l}540 \\
540\end{array}$ & 6 & 20 \\
\hline & 3527 & M $>>$ & MORTALITY & 300 & 230 & 631 & 6 & 20 \\
\hline 311 & 3528 & $\vec{F}$ & MORTALITY & 154 & 250 & 307 & 7 & 20 \\
\hline 210 & 3527 & $\mathrm{~F}$ & MORTALITY & 166 & 280 & 540 & 8 & 20 \\
\hline 317 & 3528 & $\mathrm{~F}$ & MORTALITY & 169 & 280 & 623 & 8 & 30 \\
\hline 222 & $\begin{array}{l}3527 \\
3528\end{array}$ & $\underset{F}{F}$ & $\begin{array}{l}\text { MORTALI I Y } \\
\text { MORT }\end{array}$ & 167 & $\begin{array}{l}290 \\
300\end{array}$ & $\begin{array}{l}540 \\
600\end{array}$ & $\begin{array}{l}8 \\
8\end{array}$ & $\begin{array}{l}30 \\
30\end{array}$ \\
\hline $\begin{array}{l}330 \\
158\end{array}$ & $\begin{array}{l}3528 \\
3526\end{array}$ & M & MORTALITY & 294 & $\begin{array}{l}300 \\
320\end{array}$ & $\begin{array}{l}600 \\
540\end{array}$ & $\begin{array}{l}8 \\
9\end{array}$ & $\begin{array}{l}30 \\
30\end{array}$ \\
\hline $\begin{array}{l}150 \\
318\end{array}$ & & $\mathrm{~F}$ & & 161 & 310 & 623 & 9 & $\begin{array}{l}30 \\
30\end{array}$ \\
\hline 208 & 3527 & $\mathrm{~F}$ & MORTALITY & 155 & 320 & 540 & 9 & 30 \\
\hline 154 & 3526 & M & MORTALITY & 285 & 320 & 540 & 9 & 30 \\
\hline 307 & 3528 & $\mathrm{~F}$ & MORTALITY & 151 & 320 & 540 & 9 & 30 \\
\hline $\begin{array}{l}306 \\
368\end{array}$ & $\begin{array}{l}3528 \\
2528\end{array}$ & F & MORTALI IY & 153 & $\begin{array}{l}330 \\
230\end{array}$ & 540 & 9 & 30 \\
\hline & $\begin{array}{l}3528 \\
3526\end{array}$ & $M_{F}^{M}$ & MORTALITY & $\begin{array}{l}303 \\
157 \\
\end{array}$ & $\begin{array}{l}320 \\
330\end{array}$ & $\begin{array}{l}540 \\
614\end{array}$ & $\begin{array}{l}9 \\
9\end{array}$ & $\begin{array}{l}30 \\
30\end{array}$ \\
\hline $\begin{array}{l}114 \\
348\end{array}$ & $\begin{array}{l}3526 \\
3528\end{array}$ & M & MORTALITY & $\begin{array}{l}157 \\
269\end{array}$ & $\begin{array}{l}330 \\
330\end{array}$ & $\begin{array}{l}014 \\
540\end{array}$ & $\begin{array}{l}9 \\
9\end{array}$ & $\begin{array}{l}30 \\
30\end{array}$ \\
\hline $\begin{array}{l}348 \\
106\end{array}$ & $\begin{array}{l}3528 \\
3526\end{array}$ & F & MORTALITY & $\begin{array}{l}209 \\
153\end{array}$ & 370 & $\begin{array}{l}540 \\
540\end{array}$ & $10^{9}$ & $\begin{array}{l}30 \\
30\end{array}$ \\
\hline 304 & 3528 & $\mathrm{~F}$ & MORTALITY & 160 & 390 & 540 & 11 & 30 \\
\hline 353 & 3528 & M & MORTALITY & 285 & 390 & 540 & 11 & 40 \\
\hline 167 & 3526 & M & MORTALITY & 286 & 390 & 643 & 11 & 40 \\
\hline $\begin{array}{l}341 \\
267\end{array}$ & $\begin{array}{l}3528 \\
3527\end{array}$ & $M$ & MORTALITY & $\begin{array}{l}234 \\
310\end{array}$ & 400 & 540 & 11 & 40 \\
\hline $\begin{array}{l}261 \\
303\end{array}$ & $\begin{array}{l}3521 \\
3528\end{array}$ & $\begin{array}{l}M \\
F\end{array}$ & MORTALITY & $\begin{array}{l}310 \\
158\end{array}$ & $\begin{array}{l}400 \\
400\end{array}$ & $\begin{array}{l}540 \\
540\end{array}$ & 11 & $\begin{array}{l}40 \\
40\end{array}$ \\
\hline 150 & 3526 & M & MORTALITY & $\begin{array}{l}158 \\
264\end{array}$ & $\begin{array}{l}400 \\
430\end{array}$ & $\begin{array}{l}524 \\
624\end{array}$ & 12 & $\begin{array}{l}40 \\
40\end{array}$ \\
\hline 262 & 3527 & M & MORTAL ITY & 291 & 440 & $\begin{array}{l}540 \\
540\end{array}$ & 12 & $\begin{array}{l}40 \\
40\end{array}$ \\
\hline 364 & 3528 & M & MORTALITY & 294 & 440 & 540 & 12 & 40 \\
\hline 257 & $\begin{array}{l}3527 \\
2527\end{array}$ & $M$ & HORTALITY & 302 & 450 & 540 & 12 & 40 \\
\hline $\begin{array}{l}213 \\
322\end{array}$ & $\begin{array}{l}3527 \\
3528\end{array}$ & F & $\begin{array}{l}\text { MORTAL I TY } \\
\end{array}$ & 166 & $\begin{array}{l}450 \\
480\end{array}$ & 540 & 13 & $\begin{array}{l}40 \\
40\end{array}$ \\
\hline $\begin{array}{l}323 \\
362 \\
362\end{array}$ & $\begin{array}{l}3528 \\
3528\end{array}$ & M & MORTALITY & $\begin{array}{l}160 \\
286\end{array}$ & $\begin{array}{l}480 \\
480\end{array}$ & $\begin{array}{l}540 \\
540\end{array}$ & $\begin{array}{l}13 \\
13\end{array}$ & $\begin{array}{l}40 \\
40\end{array}$ \\
\hline 248 & 3527 & M & MORTALITY & $\begin{array}{l}200 \\
247\end{array}$ & $\begin{array}{l}400 \\
490\end{array}$ & 641 & 14 & 40 \\
\hline 225 & 3527 & $\mathrm{~F}$ & MORTALITY & 169 & 490 & 540 & 14 & 40 \\
\hline 312 & 3528 & $\mathrm{~F}$ & MORTALI TY & 157 & 490 & 540 & 14 & 40 \\
\hline 358 & 3528 & M & MORTALITY & 301 & 570 & 540 & 14 & 50 \\
\hline 270 & 3527 & $M$ & MORTALITY & 327 & $\begin{array}{l}510 \\
520\end{array}$ & 630 & 14 & 50 \\
\hline $\begin{array}{l}219 \\
218\end{array}$ & $\begin{array}{l}3527 \\
3527 \\
3527\end{array}$ & F & $\begin{array}{l}\text { MORTALITY } \\
\text { MORRAL }\end{array}$ & 169 & $\begin{array}{l}520 \\
520\end{array}$ & $\begin{array}{l}540 \\
540\end{array}$ & $\begin{array}{l}14 \\
15\end{array}$ & $\begin{array}{l}50 \\
50\end{array}$ \\
\hline 367 & $\begin{array}{l}3527 \\
3528\end{array}$ & M & MORTALITY & $\begin{array}{l}168 \\
309\end{array}$ & $\begin{array}{l}520 \\
530\end{array}$ & $\begin{array}{l}540 \\
584\end{array}$ & $\begin{array}{l}15 \\
15\end{array}$ & $\begin{array}{l}50 \\
50\end{array}$ \\
\hline 列 & $\begin{array}{l}3528 \\
3528\end{array}$ & M & MORTALITY & 262 & 550 & $\begin{array}{l}504 \\
540\end{array}$ & 15 & 50 \\
\hline 314 & 3528 & $F$ & MORTALITY & 155 & 560 & 540 & 16 & 50 \\
\hline 221 & 3527 & $\mathrm{~F}$ & MORTALI TY & 169 & 570 & 540 & 16 & 50 \\
\hline 147 & 3526 & M $>>$ & MORTALI IY & 252 & 580 & 540 & 16 & 50 \\
\hline 301 & 3528 & $F$ & $\begin{array}{l}\text { MORTALI TY } \\
\text { MORTY }\end{array}$ & 143 & $\begin{array}{l}580 \\
580\end{array}$ & 522 & 16 & 50 \\
\hline 年 & $\begin{array}{l}35<8 \\
2507\end{array}$ & 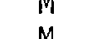 & MURTALIV & $\begin{array}{l}291 \\
295\end{array}$ & 580 & 年8 & 16 & 50 \\
\hline $\begin{array}{l}265 \\
206\end{array}$ & 3527 & $\frac{M}{F}$ & MORTALITY & $\begin{array}{l}285 \\
157\end{array}$ & $\begin{array}{l}600 \\
610\end{array}$ & $\begin{array}{l}540 \\
540\end{array}$ & 17 & $\begin{array}{l}50 \\
50\end{array}$ \\
\hline
\end{tabular}
\begin{tabular}{cc|ccc} 
gRAYS AT \\
DEATH
\end{tabular}

30

40

40

40

50

50

50
50
DIEO

ALIVE

DIED
DIED

EUTHANIZED

ALIVE

EUTHANIZED

ALIVE
AIVE
ALIVE

ALIVE
ALIVI

ALIVE
EUTHANIZED

ALLVE
ALIVE
ALIVE

ALIV
ALIVE
ALI

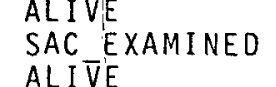

ALIVE
AIVE
ALIVE

EUTHANIZED

ALIVE
ALIVE
ALIVE

ALIVE
ALIVE

ALIVE
ALIVE

ALIVE
DIED
ALIVE

ALIVE
SAC EXAMINEO

SAL EXAMINEO
ALIVE
DIIVE

ALIVE
DIEDO
ALIVE

ALIVE
ALIVE
AIVE

ALIVE
ALIVE

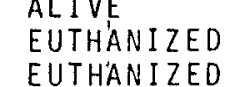

ALIVE
ALIVE
BA_HYPERPLASIA

LEUKEMIA

UREMIC PNEUMONIA $\underset{\substack{\text { MAJOR } \\ \text { FINOING }}}{\text { Fing }}$

NO_LESIONS UREMIC PNEUMONIA
RADPNEUMONITIS RAD_PNEUMONITIS CONGESTION LEUKEMIA

RAD_PNEUMONITIS

OTHER FINDINGS AT DEATH

SEPT_FIBROSIS

HEMORRHAGE

UNRESOLVED

RAD_PNEUMONITIS

RAD_PNEUMONITIS

BA_HYPERPLASIA 


\begin{tabular}{|c|c|c|c|c|}
\hline $\begin{array}{l}\text { ANIMAL } \\
\text { NUMBER }\end{array}$ & $\begin{array}{l}\text { EXPERI- } \\
\text { MENT } \\
\text { NUMBER }\end{array}$ & SEX & GROUP & $\begin{array}{l}\text { INITIAL } \\
\text { WEIGHT } \\
(g)\end{array}$ \\
\hline 227 & 3527 & $\mathrm{~F}$ & MORTALITY & 177 \\
\hline $\begin{array}{l}327 \\
357\end{array}$ & 3528 & $\mathrm{~F}$ & MORTALITY & 163 \\
\hline $\begin{array}{l}357 \\
316\end{array}$ & $\begin{array}{l}3528 \\
3528\end{array}$ & $\underset{F}{M}$ & $\begin{array}{l}\text { MORTALI TY } \\
\text { MORTALTY }\end{array}$ & 281 \\
\hline 224 & $\begin{array}{l}3528 \\
3527\end{array}$ & $\mathrm{~F}$ & MORTAL I TY & $\begin{array}{l}156 \\
166\end{array}$ \\
\hline 329 & 3528 & $\mathrm{~F}$ & MORTAL ITY & $\begin{array}{l}166 \\
175\end{array}$ \\
\hline 245 & $\begin{array}{l}3527 \\
3527\end{array}$ & $M$ & MORTALITY & $\begin{array}{l}115 \\
279\end{array}$ \\
\hline $\begin{array}{l}207 \\
256\end{array}$ & $\begin{array}{l}3527 \\
3527\end{array}$ & M & $\begin{array}{l}\text { MORTALL TY } \\
\text { MORTAI TY }\end{array}$ & $\begin{array}{l}157 \\
2770\end{array}$ \\
\hline 166 & 3526 & $M$ & MORTALI TY & $\begin{array}{l}270 \\
307\end{array}$ \\
\hline $\begin{array}{l}320 \\
216\end{array}$ & $\begin{array}{l}3528 \\
3527\end{array}$ & $\stackrel{F}{F}$ & $\begin{array}{l}\text { MORTALITYY } \\
\text { MORTALTY }\end{array}$ & 162 \\
\hline 366 & $\begin{array}{l}3528 \\
3528\end{array}$ & $M$ & MORTALI I Y & $\begin{array}{l}171 \\
304\end{array}$ \\
\hline 315 & 3528 & $\mathrm{~F}$ & MORTALITY & $\begin{array}{l}304 \\
161\end{array}$ \\
\hline & & & & $\begin{array}{l}101 \\
165\end{array}$ \\
\hline 313 & 3528 & $F$ & MORTALITY & 164 \\
\hline 203 & 3527 & $F$ & MORTALITY & 148 \\
\hline 202 & 3527 & $\mathrm{~F}$ & MORTAL I TY & 139 \\
\hline 205 & $\begin{array}{l}3527 \\
3256\end{array}$ & $F_{M}$ & $\begin{array}{l}\text { MORTALITY } \\
\text { MOT }\end{array}$ & $\begin{array}{l}160 \\
200\end{array}$ \\
\hline 214 & 3527 & $\begin{array}{c}M \\
F\end{array}$ & MORTALITY & $\begin{array}{l}295 \\
162\end{array}$ \\
\hline 165 & 3526 & $M$ & MORTALITY & 255 \\
\hline $\begin{array}{l}369 \\
345\end{array}$ & $\begin{array}{l}3528 \\
3528\end{array}$ & $M$ & $\begin{array}{l}\text { MORTAL I TY } \\
\text { MOR }\end{array}$ & $\begin{array}{r}294 \\
275\end{array}$ \\
\hline 356 & 3528 & M & MORTALITY & 271 \\
\hline $\begin{array}{l}352 \\
250\end{array}$ & 3528 & M & MORTALITY & 270 \\
\hline $\begin{array}{l}250 \\
170\end{array}$ & & & $\begin{array}{l}\text { MORTALITY } \\
\text { MORTAL TTY }\end{array}$ & $\begin{array}{l}274 \\
313\end{array}$ \\
\hline 169 & 3526 & M & MORTALITY & $\begin{array}{l}313 \\
300\end{array}$ \\
\hline 111 & 3526 & $\mathrm{~F}$ & MORTALITY & 160 \\
\hline & 3528 & & MORTALITY & 172 \\
\hline 157 & 3526 & M & MORTALITY & 279 \\
\hline 363 & 3528 & M & MORTALI TY & 281 \\
\hline & 3527 & $F$ & MORTAL ITY & 156 \\
\hline $\begin{array}{l}249 \\
250\end{array}$ & $\begin{array}{l}3521 \\
35258\end{array}$ & M & $\begin{array}{l}\text { MORTALITY } \\
\text { MORT }\end{array}$ & $\begin{array}{r}270 \\
279\end{array}$ \\
\hline 365 & $\begin{array}{l}3528 \\
3528\end{array}$ & $M$ & MORTALITY & $\begin{array}{l}279 \\
283\end{array}$ \\
\hline & 3528 & M & MORTAL ITY & 272 \\
\hline $\begin{array}{l}152 \\
326\end{array}$ & $\begin{array}{l}3526 \\
3528\end{array}$ & $M$ & MORTAL I TY & 281 \\
\hline 251 & 3527 & M & MORTALITY & \\
\hline & 3528 & & $\begin{array}{l}\text { MORTAL IY } \\
\text { MO }\end{array}$ & $\begin{array}{l}284 \\
280\end{array}$ \\
\hline 308. & 3528 & $\mathrm{~F}$ & MORTAL ITY & 141 \\
\hline 255 & 3527 & M $>>>$ & MORTALITY & 298 \\
\hline & 3528 & M & MORTALITYY & 277 \\
\hline $\begin{array}{l}155 \\
127\end{array}$ & $\begin{array}{l}3526 \\
3527\end{array}$ & M & MORTALITY & 257 \\
\hline 148 & 3526 & M & MORTALITY & $\begin{array}{l}168 \\
266\end{array}$ \\
\hline 242 & 3527 & 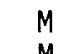 & MORTAL I TY & 242 \\
\hline & & & & \\
\hline
\end{tabular}

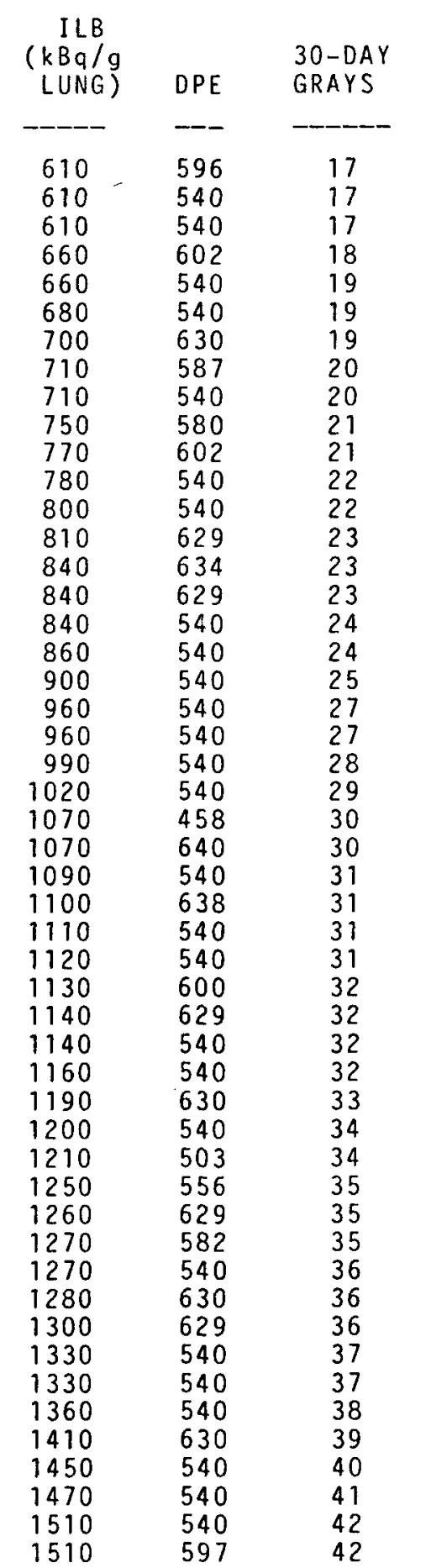

$\underset{\substack{900-D A Y \\ \text { GRAYS }}}{-}$

GRAYS AT
DEATH

MODE OF DEATH EUTHANIZED ALIVE EUTHANIZED ALIVE
AAC ExAMIUED SAC EXAMIMED
EUTHANIZED ALIVE
DIED OITHANIZD ALIVE
ALIVE

ALAC EXMINED
SAC XXAMINED SAC- EXAMINED
SACEXAMINED ALIVE ALIVE
ALIVE
ALIVE

ALIVE
ALIVE
ALIV

90
90

100

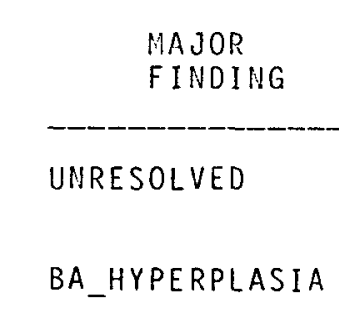

BA_HYPERPLASIA BA HYPERPDASIA
ALVEOLAR_HISTEO RAD PMEUMONITIS
ALVEOLAR_HISTEO ALVEDLAR HISTEO
RAO PNEUTOOUIIIS RAD PNEUNONIIS
NO_ESTIONS

RAD PMEUNONITIS
LEUKEEIA LEUKEMIA

RAD PNEUMONITIS BA_HYPERPLASIA MESOTHELIOMA
BA HYPERPLASIA NO- LESIONS
LEUKEMIA

BA_HYPERPLASIA

BA_HYPERPLASIA SQUAM_CELL_CA
OTHER FINDINGS A DEATH

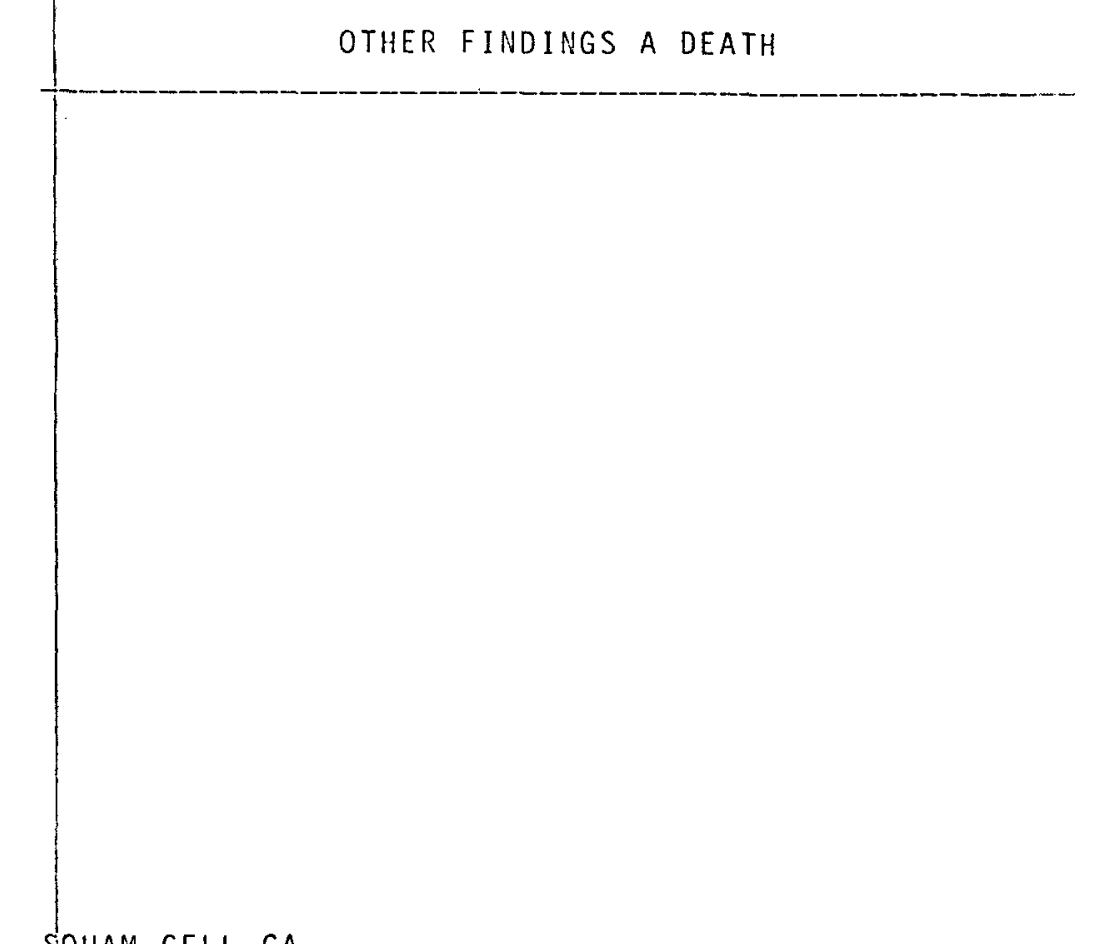




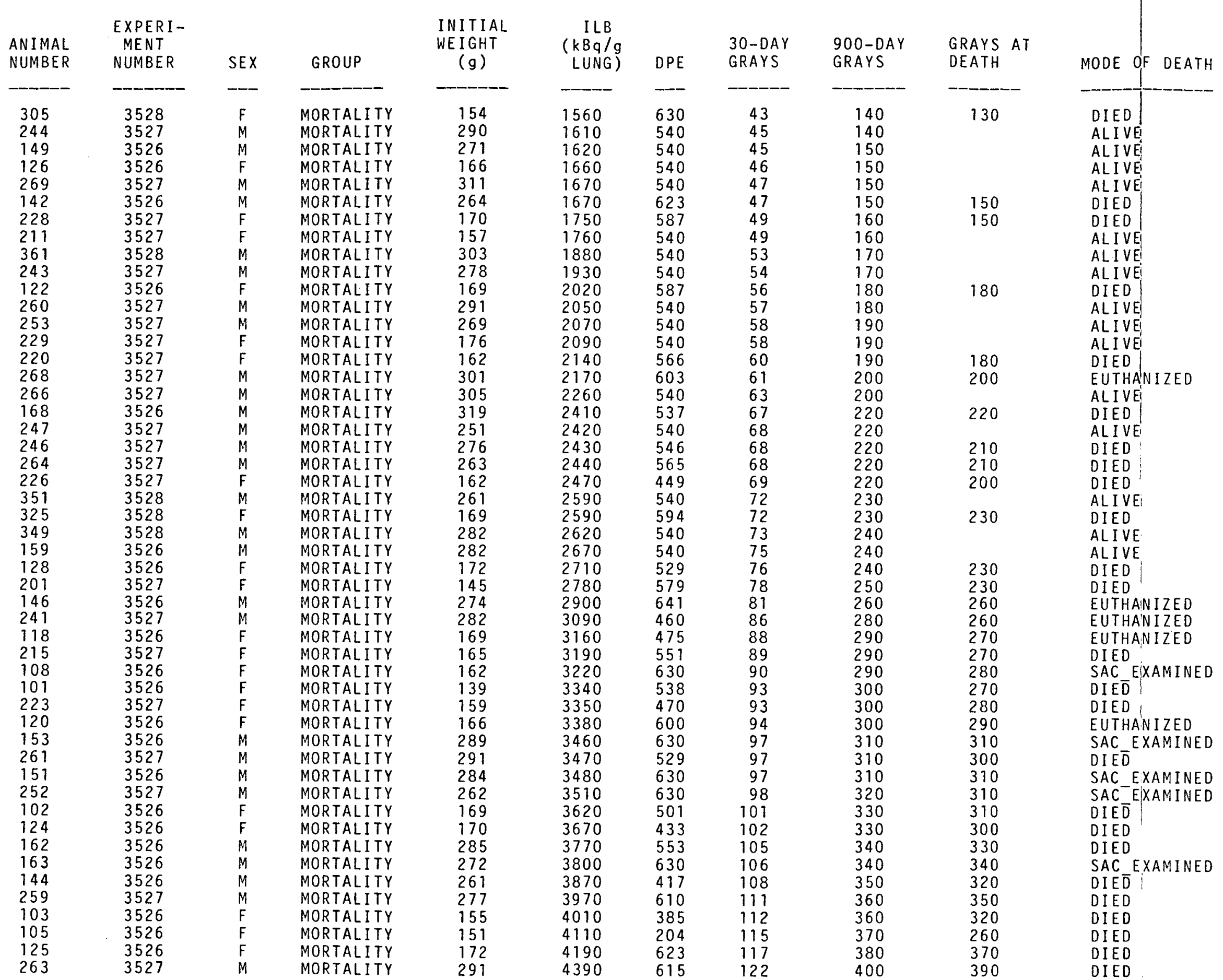

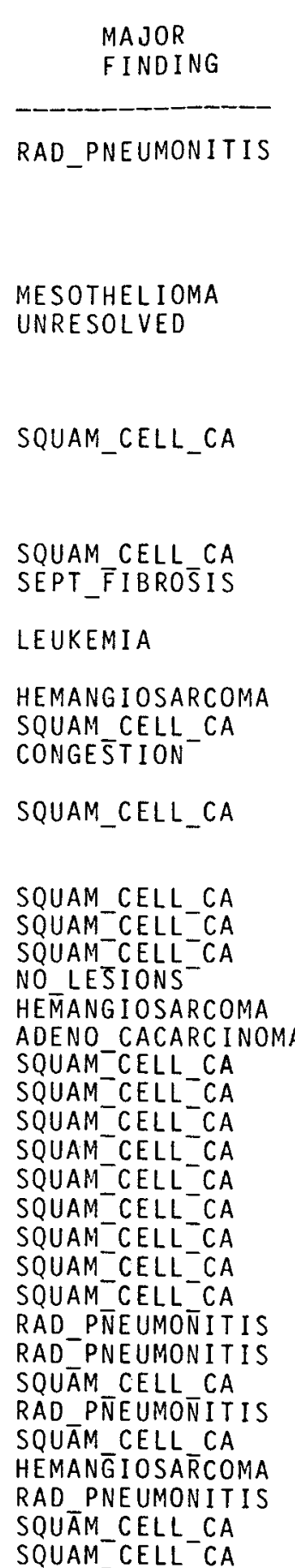

SOOAMCCELL_CA
SQUAM_CELLCA

\section{HEMORRHAGE \\ SEPT_FIBROSIS \\ BA_HYPERPLASIA \\ SQUAM_CELLCA
RAD_PNEUMONITIS, SEPT_FIBROSIS \\ RAAPPEUMONITIS, SEPT_FiBROSIS
SEPT}

OTHER FINDINGS AT DEATH BA_HY̌PERPLASIA

RAD_PNEUMONITIS, SEPT_FIBROSIS

HEMANGIOSARCOMA, RAD_PNEUMONITIS, SEPT_FIBROSIS
RAOPNEUMONITIS RAD_PNEUMONITIS

RADPPEEUMONITIS. SEPT_FIBROSIS
RADPNWUMONITIS SEPT_FIBROSIS, BA_HYPERPLASIA

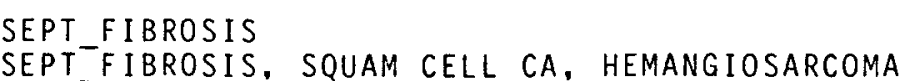

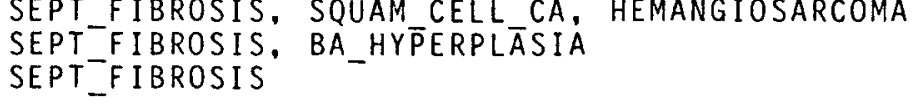
SQUAM_CELL_CA, SEPT_FIBROSIS SEPT FIBROSTIS
RAD PNEUMONITIS

RADPNEUMONITIS, SEPT_FIBROSIS 


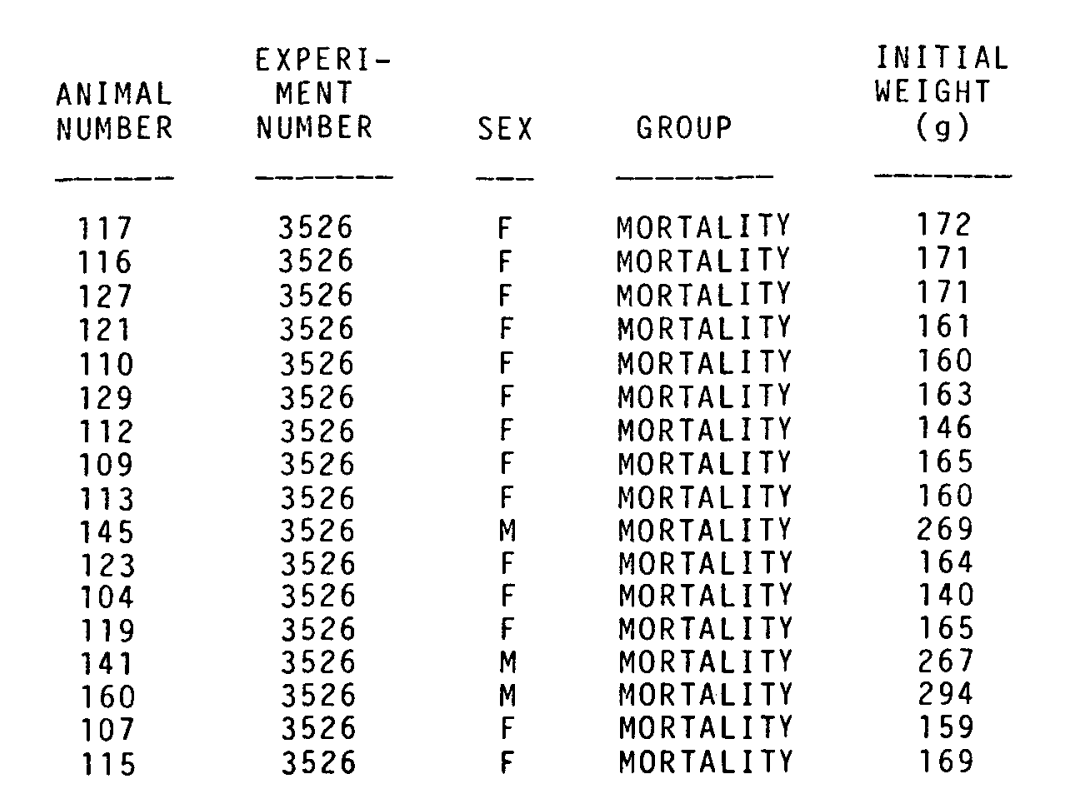

\begin{tabular}{|c|c|}
\hline 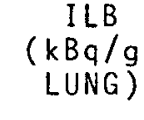 & DPE \\
\hline $\begin{array}{l}470 \\
6000\end{array}$ & $\begin{array}{l}472 \\
149\end{array}$ \\
\hline & $\begin{array}{l}556 \\
363\end{array}$ \\
\hline $\begin{array}{r}5040 \\
5280 \\
5200\end{array}$ & $\begin{array}{r}117 \\
63\end{array}$ \\
\hline $\begin{array}{r}5290 \\
5330 \\
5520\end{array}$ & $\begin{array}{r}229 \\
93\end{array}$ \\
\hline $\begin{array}{l}0 \\
0 \\
0\end{array}$ & $\begin{array}{l}100 \\
252\end{array}$ \\
\hline 5170 & $\begin{array}{l}135 \\
149\end{array}$ \\
\hline $\begin{array}{l}570 \\
8880 \\
98600\end{array}$ & $\begin{array}{l}132 \\
138 \\
106\end{array}$ \\
\hline $\begin{array}{l}69600 \\
7060\end{array}$ & $\begin{array}{l}106 \\
130\end{array}$ \\
\hline
\end{tabular}

\begin{tabular}{l}
$900-$ DAY \\
GRAYS \\
\hline 400 \\
410 \\
410 \\
420 \\
450 \\
480 \\
480 \\
480 \\
500 \\
520 \\
530 \\
550 \\
590 \\
520 \\
620 \\
630 \\
640
\end{tabular}

\begin{tabular}{l} 
GRAYS AT \\
DEATH \\
\hline 380 \\
260 \\
400 \\
360 \\
260 \\
200 \\
310 \\
240 \\
270 \\
280 \\
420 \\
330 \\
380 \\
360 \\
340 \\
380
\end{tabular}

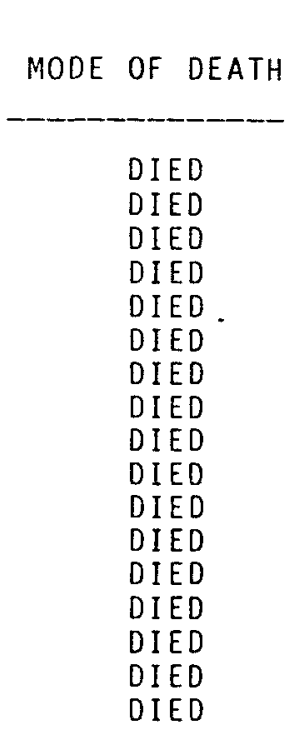

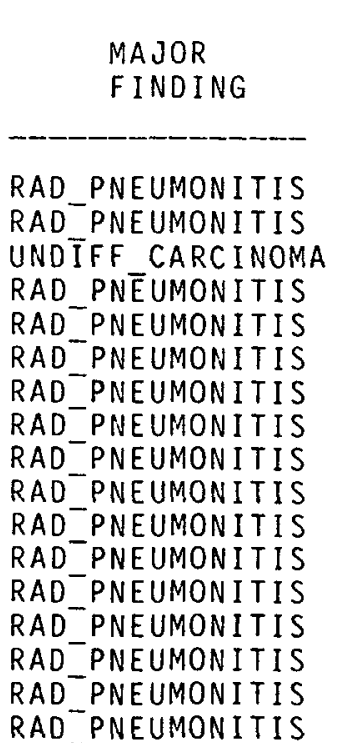

\begin{tabular}{|c|}
\hline OTHER FINDINGS AT DEATH \\
\hline 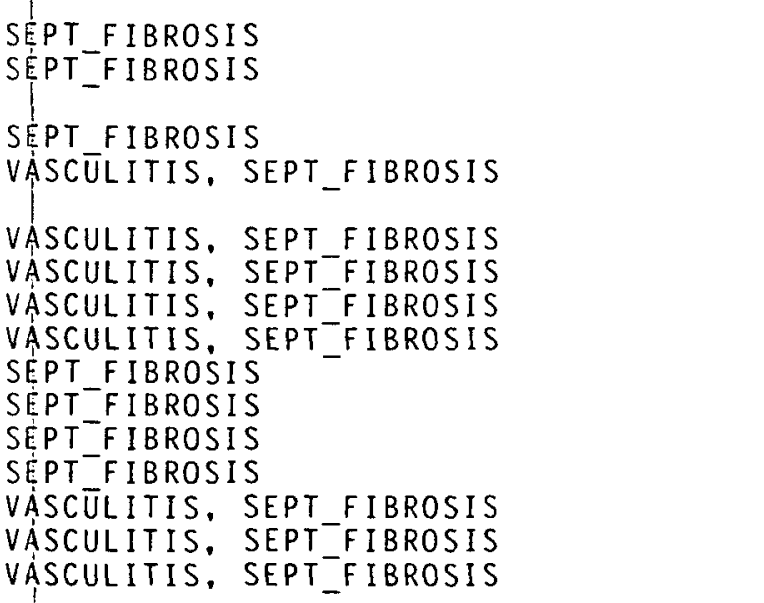 \\
\hline
\end{tabular}


6A. PULMONARY FUNCTION MEASUREMENTS FOR RATS EXPOSED VIA INHALATION TO SR9O-FAP

\begin{tabular}{|c|c|c|c|c|c|}
\hline $\begin{array}{l}\text { ANIMAL } \\
\text { NUMBER }\end{array}$ & $\begin{array}{c}\text { EXPERIMENT } \\
\text { NUMBER }\end{array}$ & SEX & $\begin{array}{l}\text { MONTHS } \\
\text { AFTER } \\
\text { EXPOSURE }\end{array}$ & $\begin{array}{c}\text { CUMULATIVE } \\
\text { DOSE } \\
(\text { Gy })\end{array}$ & $\begin{array}{l}\text { VITAL } \\
\text { CAPACITY } \\
(\mathrm{ml})\end{array}$ \\
\hline 121 & 3522 & $F$ & 0 & 0 & 9.4 \\
\hline 122 & 3522 & $\mathrm{~F}$ & 0 & 0 & 8.3 \\
\hline 124 & 3522 & $F$ & 0 & 0 & 9.0 \\
\hline 125 & 3522 & $\mathrm{~F}$ & 0 & 0 & 8.2 \\
\hline 127 & 3522 & $\mathrm{~F}$ & 0 & 0 & 8.6 \\
\hline 128 & 3522 & $\mathrm{~F}$ & 0 & 0 & 8.2 \\
\hline 129 & 3522 & $F$ & 0 & 0 & 8.8 \\
\hline 130 & 3522 & $\mathrm{~F}$ & 0 & 0 & 8.1 \\
\hline 221 & 3523 & $F$ & 0 & 0 & 8.6 \\
\hline 222 & 3523 & $\mathrm{~F}$ & 0 & 0 & 9.2 \\
\hline 223 & 3523 & $F$ & 0 & 0 & 9.1 \\
\hline 224 & 3523 & $F$ & 0 & 0 & 7.8 \\
\hline 225 & 3523 & $\mathrm{~F}$ & 0 & 0 & 7.7 \\
\hline 226 & 3523 & $\mathrm{~F}$ & 0 & 0 & 7.9 \\
\hline 227 & 3523 & $\mathrm{~F}$ & 0 & 0 & 8.8 \\
\hline 228 & 3523 & $\mathrm{~F}$ & 0 & 0 & $\begin{array}{r}0.0 \\
\end{array}$ \\
\hline 229 & 3523 & $\mathrm{~F}$ & 0 & 0 & 9.6 \\
\hline 230 & 3523 & $F$ & 0 & 0 & 8.5 \\
\hline 321 & 3524 & $\mathrm{~F}$ & 0 & 0 & 7.3 \\
\hline 322 & 3524 & $F$ & 0 & 0 & 9.4 \\
\hline 323 & 3524 & $\mathrm{~F}$ & 0 & 0 & 9.7 \\
\hline 324 & 3524 & $\mathrm{~F}$ & 0 & 0 & 9.3 \\
\hline $\begin{array}{l}324 \\
325\end{array}$ & 3524 & $\mathrm{~F}$ & 0 & 0 & 10.8 \\
\hline 326 & 3524 & $F$ & 0 & 0 & 10.0 \\
\hline 327 & 3524 & $F$ & 0 & 0 & 10.1 \\
\hline 328 & 3524 & $\mathrm{~F}$ & 0 & 0 & 10.2 \\
\hline 421 & 3525 & $\mathrm{~F}$ & 0 & 0 & 9.2 \\
\hline 422 & 3525 & $\mathrm{~F}$ & 0 & 0 & 9.6 \\
\hline 423 & 3525 & $\mathrm{~F}$ & 0 & 0 & 10.1 \\
\hline 424 & 3525 & $\mathrm{~F}$ & 0 & 0 & 10.1 \\
\hline 425 & 3525 & $F$ & 0 & 0 & 8,3 \\
\hline 426 & 3525 & $\mathrm{~F}$ & 0 & 0 & $\begin{array}{l}0.3 \\
8.8\end{array}$ \\
\hline 427 & 3525 & $\mathrm{~F}$ & 0 & 0 & 9.1 \\
\hline 428 & 3525 & $F$ & 0 & 0 & 10.0 \\
\hline 429 & 3525 & $\mathrm{~F}$ & 0 & 0 & 9.6 \\
\hline 430 & 3525 & $\mathrm{~F}$ & 0 & 0 & 8.7 \\
\hline $\begin{array}{l}140 \\
141\end{array}$ & 3522 & $M$ & 0 & 0 & 11.0 \\
\hline 142 & 3522 & $M$ & 0 & 0 & 10.2 \\
\hline 143 & 3522 & $M$ & 0 & 0 & 11.2 \\
\hline 145 & 3522 & $M$ & 0 & 0 & 9.6 \\
\hline 146 & 3522 & M & 0 & 0 & 11.5 \\
\hline 147 & 3522 & $M$ & 0 & 0 & 11.4 \\
\hline 148 & 3522 & $M$ & 0 & 0 & 10.0 \\
\hline 150 & 3522 & $M$ & 0 & 0 & 11.3 \\
\hline 242 & 3523 & M & 0 & 0 & 9.2 \\
\hline & & & & & \\
\hline
\end{tabular}

VITAL TO TOTAL DIFFUSING (maPACITY

0.85

$\begin{array}{ll}0.85 & 0.17 \\ 0.79 & 0.15 \\ 0.86 & 0.16 \\ 0.83 & 0.15 \\ 0.81 & 0.15 \\ 0.86 & 0.13\end{array}$

0.86
0.83
0.81

0.86

0.83

0.83

0.84

0.75

0.80
0.84

0.84

0.85
0.87

0.81

0.76

0.80

0.86
0.85
0.80

0.79

0.85

0.83
0.83
0.84

0.84

0.82

0.87
0.72

0.86

0.82

0.88

0.80

0.84

0.85

0.85
0.87
0.88

0.87

0.86
0.86
0.84

0.84
0.86

0.18

0.15

0.15

0.15

0.15
0.15
0.17
0.18

0.18

0.16

0.18

0.15

0.17

0.18
0.18
0.14

0.14
0.17

0.19

0.16

0.11
0.15

0.20

0.14

0.24
0.23
0.21

0.21

0.20

0.20

0.19

0.19
0.15
DIFFUSING PER kg PER kg

DIFFUSING CAPACITY PE

CI ALVEOLAR
VOLUME

QUASISTATIC

COMPLIANCE SLOPE

1.01

0.93
1.03
0.93

0.93
0.92
0.81
0.81

$\begin{array}{ll}0.13 & 0.81 \\ 0.14 & 0.81 \\ 0.17 & 1.06 \\ 0.15 & 0.94\end{array}$

1.12
0.97
0.98

0.98
0.96

0.93

0.94
1.02
1.10
0.97
1.03

0.97

1.03

1.02
0.85

1.08
0.98

1.04

0.91

0.96

1.10
1.22
1.00

1.00
0.66

0.92

1.21
0.91

0.90

1.09

.08
0.89

0.85

0.85

0.87

0.81
0.89
0.66

0.66

0.018

PHASE

$\begin{array}{lll}0.017 & 0.62 & 0.46 \\ 0.018 & 0.48 & 0.46\end{array}$

$\begin{array}{lll}0.018 & 0.62 & 0.47\end{array}$

$\begin{array}{lll}0.016 & 0.55 & 0.43 \\ 0.015 & 0.56 & 0.43 \\ 0.021 & 0.53 & 0.53\end{array}$

$\begin{array}{lll}0.0218 & 0.61 & 0.53\end{array}$

$\begin{array}{lll}0.019 & 0.66 & 0.41\end{array}$

$\begin{array}{lll}0.016 & 0.63 & 0.43 \\ 0.018 & 0.52 & 0.76\end{array}$

$\begin{array}{lll}0.019 & 0.49 & 0.45\end{array}$

$\begin{array}{lll}0.018 & 0.51 & 0.47 \\ 0.018 & 0.66 & 0.46\end{array}$

$\begin{array}{lll}0.018 & 0.66 & 0.46 \\ 0.018 & 0.79 & 0.36 \\ 0.019 & 0.68 & 0.38\end{array}$

$\begin{array}{lll}0.019 & 0.66 & 0.48\end{array}$

$\begin{array}{lll}0.017 & 0.47 & 0.45\end{array}$

$\begin{array}{lll}0.018 & 0.70 & 0.48 \\ 0.019 & 0.71 & 0.42 \\ 0.014 & 0.64 & 0.39\end{array}$

$\begin{array}{lll}0.014 & 0.64 & 0.39\end{array}$

0.018

0.017

0.016

0.017

0.019

0.017

0.014

0.016

0.016

0.015

0.020

0.019

0.019

0.018

0.018

0.018

0.018
0.020 0.74

$0.75-0.42$

$\begin{array}{ll}0.71 & 0.41 \\ 0.75 & 0.53\end{array}$

$\begin{array}{ll}0.75 & 0.35 \\ 0.66 & 0.75 \\ 0.64 & 0.42\end{array}$

$\begin{array}{ll}0.64 & 0.42\end{array}$

$\begin{array}{ll}0.667 & 0.75 \\ 0.76 & 0.39 \\ 0.76 & 0.45\end{array}$

$\begin{array}{ll}0.63 & 0.42\end{array}$

$\begin{array}{ll}0.59 & 0.33 \\ 0.80 & 0.48\end{array}$

$\begin{array}{ll}0.69 & 0.48\end{array}$

$\begin{array}{ll}0.82 & 0.36 \\ 0.67 & 0.43\end{array}$

$\begin{array}{ll}0.79 & 0.34\end{array}$

$0.80 \quad 0.34$

$0.81 \quad 0.32$

$\begin{array}{ll}0.65 & 0.48 \\ 0.81 & 0.37\end{array}$ 
6B. PULMONARY FUNCTION MEASUREMENTS FOR RATS EXPOSED VIA INHALATION TO SR90-FAP

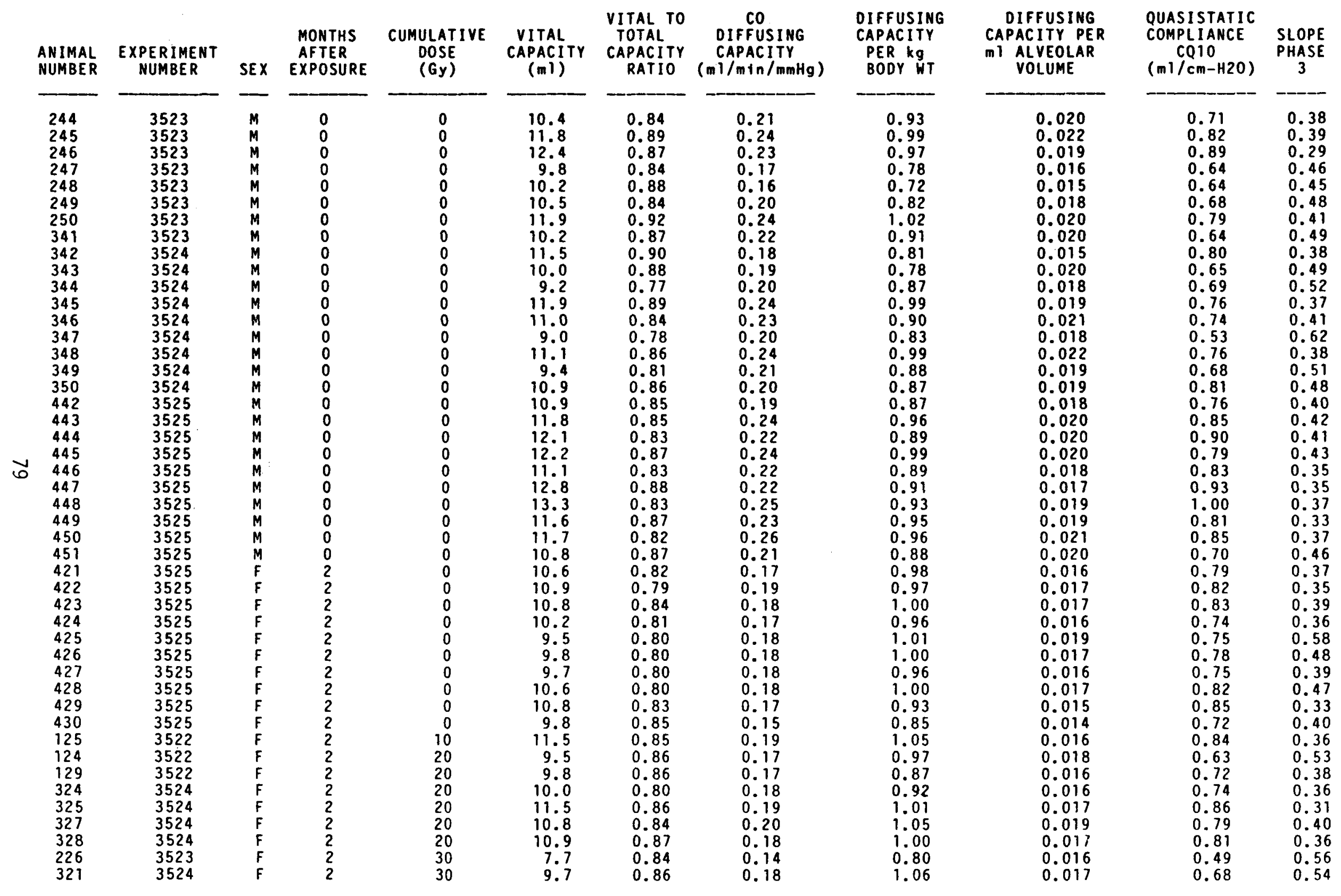


6C. PULMONARY FUNCTION MEASUREMENTS FOR RATS

EXPOSEO VIA INHALATION TO SR9O-FAP

\begin{tabular}{|c|c|c|c|c|c|c|c|c|c|c|c|}
\hline $\begin{array}{l}\text { ANIMAL } \\
\text { NUMBER }\end{array}$ & $\begin{array}{c}\text { EXPERIMENT } \\
\text { NUMBER }\end{array}$ & SEX & $\begin{array}{l}\text { MONTHS } \\
\text { AFTER } \\
\text { EXPOSURE }\end{array}$ & $\begin{array}{c}\text { CUMULATIVE } \\
\text { DOSE } \\
(G y)\end{array}$ & $\begin{array}{l}\text { VITAL } \\
\text { CAPACITY } \\
(\mathrm{ml})\end{array}$ & $\begin{array}{l}\text { VITAL TO } \\
\text { TOTAL } \\
\text { CAPACITY } \\
\text { RATIO }\end{array}$ & $\begin{array}{c}\text { CO } \\
\text { DIFFUSING } \\
\text { CAPACITY } \\
(\mathrm{m} 1 / \mathrm{m} \mathrm{n} / \mathrm{mmHg})\end{array}$ & $\begin{array}{l}\text { DIFFUSING } \\
\text { CAPACITY } \\
\text { PER kg } \\
\text { BODY WT }\end{array}$ & $\begin{array}{l}\text { DIFFUSING } \\
\text { CAPACITY PER } \\
\text { m } 1 \text { ALVEOLAR } \\
\text { VOLUME }\end{array}$ & $\begin{array}{c}\text { QUASISTATIC } \\
\text { COMPLIANCE } \\
\text { CQ10 } \\
(\mathrm{ml} / \mathrm{cm}-\mathrm{H} 20)\end{array}$ & $\begin{array}{c}\text { SLOPE } \\
\text { PHASE } \\
3\end{array}$ \\
\hline $\begin{array}{l}322 \\
323 \\
326 \\
128 \\
228 \\
127 \\
225 \\
121 \\
221 \\
222 \\
230 \\
227 \\
229 \\
223 \\
122 \\
224 \\
130 \\
143 \\
347 \\
442 \\
443 \\
444 \\
445 \\
446 \\
447 \\
448 \\
449 \\
450 \\
451 \\
141 \\
142 \\
341 \\
344 \\
250 \\
342 \\
146 \\
349 \\
150 \\
247 \\
145 \\
350 \\
345 \\
343 \\
346 \\
348 \\
248\end{array}$ & $\begin{array}{l}3524 \\
3524 \\
3524 \\
3522 \\
3523 \\
3522 \\
3523 \\
3522 \\
3523 \\
3523 \\
3523 \\
3523 \\
3523 \\
3523 \\
3522 \\
3523 \\
3522 \\
3522 \\
3524 \\
3525 \\
3525 \\
3525 \\
3525 \\
3525 \\
3525 \\
3525 \\
3525 \\
3525 \\
3525 \\
3522 \\
3522 \\
3523 \\
3524 \\
3523 \\
3524 \\
3522 \\
3524 \\
3522 \\
3523 \\
3522 \\
3524 \\
3524 \\
3524 \\
3524 \\
3524 \\
3523\end{array}$ & $\begin{array}{l}F \\
F \\
F \\
F \\
F \\
F \\
F \\
F \\
F \\
F \\
F \\
F \\
F \\
F \\
F \\
F \\
F \\
M \\
M \\
M \\
M \\
M \\
M \\
M \\
M\end{array}$ & $\begin{array}{l}2 \\
2 \\
2 \\
2 \\
2 \\
2 \\
2 \\
2 \\
2 \\
2 \\
2 \\
2 \\
2 \\
2 \\
2 \\
2 \\
2 \\
2 \\
2 \\
2 \\
2 \\
2 \\
2 \\
2 \\
2 \\
2 \\
2 \\
2 \\
2 \\
2 \\
2 \\
2 \\
2 \\
2 \\
2 \\
2 \\
2 \\
2 \\
2 \\
2 \\
2 \\
2 \\
2 \\
2 \\
2 \\
2\end{array}$ & $\begin{array}{r}30 \\
30 \\
30 \\
40 \\
40 \\
50 \\
60 \\
70 \\
80 \\
100 \\
100 \\
110 \\
120 \\
150 \\
180 \\
200 \\
310 \\
0 \\
0 \\
0 \\
0 \\
0 \\
0 \\
0 \\
0 \\
0 \\
0 \\
0 \\
0 \\
0 \\
0 \\
0 \\
10 \\
20 \\
20 \\
20 \\
30 \\
30 \\
40 \\
40 \\
50 \\
50 \\
60 \\
60 \\
70 \\
90 \\
100 \\
100 \\
110\end{array}$ & $\begin{array}{r}10.4 \\
10.4 \\
11.2 \\
9.5 \\
9.9 \\
9.9 \\
7.9 \\
10.7 \\
8.6 \\
8.5 \\
9.3 \\
9.1 \\
10.3 \\
8.8 \\
9.5 \\
7.8 \\
8.6 \\
11.9 \\
13.9 \\
13.8 \\
13.0 \\
14.0 \\
14.7 \\
12.9 \\
13.8 \\
15.0 \\
14.0 \\
13.9 \\
12.7 \\
12.6 \\
12.5 \\
14.0 \\
13.0 \\
14.4 \\
13.6 \\
12.7 \\
14.0 \\
13.4 \\
12.2 \\
7.3 \\
11.6 \\
13.7 \\
13.1 \\
12.7 \\
13.6 \\
12.7\end{array}$ & $\begin{array}{l}0.82 \\
0.84 \\
0.85 \\
0.86 \\
0.83 \\
0.67 \\
0.84 \\
0.85 \\
0.63 \\
0.83 \\
0.84 \\
0.84 \\
0.88 \\
0.88 \\
1.13 \\
0.82 \\
0.85 \\
0.95 \\
0.87 \\
0.83 \\
0.88 \\
0.88 \\
0.86 \\
0.88 \\
0.82 \\
0.86 \\
0.85 \\
0.83 \\
0.85 \\
0.77 \\
0.88 \\
0.82 \\
0.85 \\
0.87 \\
0.91 \\
0.86 \\
0.83 \\
0.86 \\
0.89 \\
0.80 \\
0.88 \\
0.82 \\
0.81 \\
0.78 \\
0.81 \\
0.85\end{array}$ & $\begin{array}{l}0.20 \\
0.18 \\
0.22 \\
0.19 \\
0.21 \\
0.14 \\
0.12 \\
0.16 \\
0.14 \\
0.11 \\
0.17 \\
0.14 \\
0.18 \\
0.12 \\
0.15 \\
0.09 \\
0.10 \\
0.25 \\
0.28 \\
0.23 \\
0.28 \\
0.24 \\
0.22 \\
0.23 \\
0.22 \\
0.33 \\
0.22 \\
0.26 \\
0.24 \\
0.28 \\
0.27 \\
0.27 \\
0.21 \\
0.25 \\
0.22 \\
0.27 \\
0.25 \\
0.24 \\
0.25 \\
0.17 \\
0.20 \\
0.25 \\
0.27 \\
0.224 \\
0.22 \\
0.21\end{array}$ & $\begin{array}{l}1.04 \\
0.95 \\
1.15 \\
1.07 \\
1.09 \\
0.79 \\
0.68 \\
0.86 \\
0.77 \\
0.64 \\
0.97 \\
0.81 \\
0.97 \\
0.69 \\
0.86 \\
0.56 \\
0.59 \\
0.89 \\
0.92 \\
0.80 \\
0.92 \\
0.79 \\
0.69 \\
0.75 \\
0.75 \\
1.00 \\
0.71 \\
0.81 \\
0.86 \\
0.98 \\
0.96 \\
0.90 \\
0.76 \\
0.79 \\
0.78 \\
0.94 \\
0.81 \\
0.75 \\
0.85 \\
0.64 \\
0.70 \\
0.85 \\
0.85 \\
0.79 \\
0.73 \\
0.74\end{array}$ & $\begin{array}{l}0.018 \\
0.017 \\
0.018 \\
0.018 \\
0.019 \\
0.015 \\
0.014 \\
0.015 \\
0.015 \\
0.014 \\
0.016 \\
0.015 \\
0.016 \\
0.013 \\
0.016 \\
0.011 \\
0.013 \\
0.020 \\
0.020 \\
0.015 \\
0.021 \\
0.016 \\
0.015 \\
0.017 \\
0.015 \\
0.021 \\
0.015 \\
0.020 \\
0.020 \\
0.021 \\
0.021 \\
0.019 \\
0.016\end{array}$ & $\begin{array}{l}0.77 \\
0.79 \\
0.81 \\
0.69 \\
0.64 \\
0.71 \\
0.59 \\
0.77 \\
0.67 \\
0.65 \\
0.75 \\
0.66 \\
0.75 \\
0.58 \\
0.66 \\
0.56 \\
0.66 \\
0.75 \\
0.97 \\
1.04 \\
0.94 \\
1.10 \\
1.06 \\
0.96 \\
1.08 \\
1.17 \\
1.03 \\
1.00 \\
0.84 \\
0.90 \\
0.91 \\
1.08 \\
0.91 \\
1.11 \\
0.99 \\
0.88 \\
1.03 \\
0.96 \\
0.95 \\
0.48 \\
0.77 \\
1.01 \\
0.93 \\
0.97 \\
1.06 \\
0.98\end{array}$ & $\begin{array}{l}0.50 \\
0.41 \\
0.37 \\
0.41 \\
0.38 \\
0.60 \\
0.71 \\
0.36 \\
0.64 \\
0.60 \\
0.33 \\
0.37 \\
0.37 \\
0.46 \\
0.44 \\
0.64 \\
0.57 \\
0.58 \\
0.38 \\
0.28 \\
0.51 \\
0.31 \\
0.26 \\
0.33 \\
0.27 \\
0.32 \\
0.25 \\
0.37 \\
0.40 \\
0.49 \\
0.37 \\
0.36 \\
0.36 \\
0.43 \\
0.42 \\
0.34 \\
0.37 \\
0.51 \\
0.67 \\
0.69 \\
0.45 \\
0.45 \\
0.44 \\
0.40 \\
0.43 \\
0.39\end{array}$ \\
\hline
\end{tabular}


5D. PULMONARY FUNCTION MEASUREMENTS FOR RATS EXPOSED VIA INHALATION TO SR90-FAP

\begin{tabular}{|c|c|c|c|c|c|c|c|c|c|c|c|}
\hline $\begin{array}{l}\text { ANIMAL } \\
\text { NUMBER }\end{array}$ & $\begin{array}{l}\text { EXPERIMENT } \\
\text { NUMBER }\end{array}$ & SEX & $\begin{array}{l}\text { MONTHS } \\
\text { AFTER } \\
\text { EXPOSURE }\end{array}$ & $\begin{array}{l}\text { CUMULAT IVE } \\
\text { DOSE } \\
\text { (GY) }\end{array}$ & $\begin{array}{c}\text { VITAL } \\
\text { CAPACITY } \\
(\mathrm{mI})\end{array}$ & $\begin{array}{l}\text { VITAL TO } \\
\text { TOTAL } \\
\text { CAPACITY } \\
\text { RATIO }\end{array}$ & $\begin{array}{c}\text { CO } \\
\text { DIFFUSING } \\
\text { CAPACITY } \\
(\mathrm{m} 1 / \mathrm{min} / \mathrm{mmHg})\end{array}$ & $\begin{array}{l}\text { DIFFUSING } \\
\text { CAPACITY } \\
\text { PER kg } \\
\text { BODY WT }\end{array}$ & $\begin{array}{l}\text { DIFFUSING } \\
\text { CAPACITY PER } \\
\text { m } 1 \text { ALVEOLAR } \\
\text { VOLUME }\end{array}$ & $\begin{array}{c}\text { QUASISTATIC } \\
\text { COMPLIANCE } \\
\text { CQ10 } \\
(\mathrm{m} 1 / \mathrm{cm}-\mathrm{H} 2 \mathrm{O})\end{array}$ & $\begin{array}{c}\text { SLOPE } \\
\text { PHASE } \\
3\end{array}$ \\
\hline $\begin{array}{l}147 \\
242 \\
148 \\
246 \\
243 \\
244 \\
245 \\
249 \\
421 \\
422 \\
423 \\
424 \\
425 \\
426 \\
427 \\
428 \\
429 \\
430 \\
125 \\
324 \\
325 \\
327 \\
328 \\
124 \\
129 \\
226 \\
323 \\
326 \\
128 \\
321 \\
322 \\
127 \\
228 \\
121 \\
225 \\
221 \\
230 \\
222 \\
227 \\
229 \\
223 \\
122 \\
224 \\
130 \\
143 \\
347\end{array}$ & $\begin{array}{l}3522 \\
3523 \\
3522 \\
3523 \\
3523 \\
3523 \\
3523 \\
3523 \\
3525 \\
3525 \\
3525 \\
3525 \\
3525 \\
3525 \\
3525 \\
3525 \\
3525 \\
3525 \\
3522 \\
3524 \\
3524 \\
3524 \\
3524 \\
3522 \\
3522 \\
3523 \\
3524 \\
3524 \\
3522 \\
3524 \\
3524 \\
3522 \\
3523 \\
3522 \\
3523 \\
3523 \\
3523 \\
3523 \\
3523 \\
3523 \\
3523 \\
3522 \\
3523 \\
3522 \\
3522 \\
3524\end{array}$ & $\begin{array}{l}M \\
M \\
M \\
M \\
M \\
M \\
M \\
M \\
F \\
F \\
F \\
F \\
F \\
F \\
F \\
F \\
F \\
F \\
F \\
F \\
F \\
F \\
F \\
F \\
F \\
F \\
F \\
F \\
F \\
F \\
F \\
F \\
F \\
F \\
F \\
F \\
F \\
F \\
F \\
F \\
F \\
F \\
F \\
F \\
M \\
M\end{array}$ & $\begin{array}{l}2 \\
2 \\
2 \\
2 \\
2 \\
2 \\
2 \\
2 \\
3 \\
3 \\
3 \\
3 \\
3 \\
3 \\
3 \\
3 \\
3 \\
3 \\
3 \\
3 \\
3 \\
3 \\
3 \\
3 \\
3 \\
3 \\
3 \\
3 \\
3 \\
3 \\
3 \\
3 \\
3 \\
3 \\
3 \\
3 \\
3 \\
3 \\
3 \\
3 \\
3 \\
3 \\
3 \\
3 \\
3 \\
3\end{array}$ & $\begin{array}{r}120 \\
130 \\
140 \\
160 \\
170 \\
170 \\
190 \\
220 \\
0 \\
0 \\
0 \\
0 \\
0 \\
0 \\
0 \\
0 \\
0 \\
0 \\
0 \\
20 \\
20 \\
20 \\
20 \\
20 \\
30 \\
30 \\
40 \\
40 \\
40 \\
50 \\
50 \\
50 \\
60 \\
60 \\
90 \\
90 \\
110 \\
130 \\
140 \\
150 \\
160 \\
200 \\
240 \\
260 \\
420 \\
0 \\
0\end{array}$ & $\begin{array}{r}12.6 \\
10.6 \\
11.9 \\
13.4 \\
11.5 \\
12.3 \\
11.7 \\
13.3 \\
10.5 \\
11.5 \\
11.3 \\
11.0 \\
9.4 \\
10.2 \\
9.9 \\
10.8 \\
11.0 \\
10.3 \\
12.0 \\
11.8 \\
11.5 \\
10.8 \\
10.9 \\
10.7 \\
10.8 \\
9.7 \\
11.5 \\
11.7 \\
10.9 \\
10.8 \\
10.8 \\
10.8 \\
12.2 \\
10.9 \\
9.6 \\
10.0 \\
9.9 \\
10.3 \\
9.7 \\
10.2 \\
10.4 \\
9.2 \\
6.6 \\
8.8 \\
13.1 \\
14.0\end{array}$ & $\begin{array}{l}0.87 \\
0.85 \\
0.92 \\
0.84 \\
0.88 \\
0.82 \\
0.88 \\
0.85 \\
0.85 \\
0.89 \\
0.89 \\
0.87 \\
0.85 \\
0.86 \\
0.85 \\
0.89 \\
0.83 \\
0.88 \\
0.93 \\
0.88 \\
0.86 \\
0.81 \\
0.83 \\
0.86 \\
0.87 \\
0.85 \\
0.83 \\
0.89 \\
0.84 \\
0.87 \\
0.82 \\
0.86 \\
0.92 \\
0.88 \\
0.87 \\
0.85 \\
0.87 \\
0.85 \\
0.87 \\
0.83 \\
0.85 \\
0.85 \\
0.78 \\
0.84 \\
0.88 \\
0.87\end{array}$ & $\begin{array}{l}0.22 \\
0.15 \\
0.17 \\
0.20 \\
0.18 \\
0.15 \\
0.19 \\
0.21 \\
0.18 \\
0.23 \\
0.18 \\
0.21 \\
0.18 \\
0.16 \\
0.19 \\
0.20 \\
0.20 \\
0.15 \\
0.20 \\
0.20 \\
0.20 \\
0.20 \\
0.19 \\
0.18 \\
0.16 \\
0.15 \\
0.20 \\
0.20 \\
0.14 \\
0.16 \\
0.23 \\
0.18 \\
0.22 \\
0.18 \\
0.15 \\
0.17 \\
0.15 \\
0.16 \\
0.16 \\
0.15 \\
0.14 \\
0.11 \\
0.07 \\
0.13 \\
0.26 \\
0.27\end{array}$ & $\begin{array}{l}0.78 \\
0.60 \\
0.60 \\
0.70 \\
0.64 \\
0.52 \\
0.63 \\
0.77 \\
1.01 \\
1.14 \\
0.99 \\
1.14 \\
1.06 \\
0.86 \\
0.96 \\
1.08 \\
1.12 \\
0.83 \\
1.05 \\
1.05 \\
1.08 \\
1.01 \\
1.02 \\
1.00 \\
0.80 \\
0.85 \\
1.02 \\
1.01 \\
0.80 \\
0.92 \\
1.19 \\
1.01 \\
1.07 \\
0.95 \\
0.85 \\
0.92 \\
0.86 \\
0.92 \\
0.91 \\
0.80 \\
0.76 \\
0.60 \\
0.44 \\
0.73 \\
0.86 \\
0.86\end{array}$ & $\begin{array}{l}0.016 \\
0.013 \\
0.014 \\
0.015 \\
0.015 \\
0.012 \\
0.017 \\
0.014 \\
0.017 \\
0.018 \\
0.017 \\
0.017 \\
0.019 \\
0.015 \\
0.017 \\
0.016 \\
0.019 \\
0.014 \\
0.017 \\
0.017 \\
0.017 \\
0.017 \\
0.017 \\
0.017 \\
0.015\end{array}$ & $\begin{array}{l}0.91 \\
0.78 \\
0.79 \\
1.02 \\
0.85 \\
0.99 \\
0.95 \\
1.02 \\
0.80 \\
0.86 \\
0.84 \\
0.84 \\
0.67 \\
0.77 \\
0.69 \\
0.78 \\
0.81 \\
0.76 \\
0.83 \\
0.83 \\
0.83 \\
0.86 \\
0.81 \\
0.80 \\
0.78 \\
0.68 \\
0.86 \\
0.86 \\
0.76 \\
0.79 \\
0.83 \\
0.77 \\
0.87 \\
0.79 \\
0.71 \\
0.75 \\
0.73 \\
0.78 \\
0.69 \\
0.76 \\
0.79 \\
0.68 \\
0.44 \\
0.63 \\
0.96 \\
1.00\end{array}$ & $\begin{array}{l}0.51 \\
0.32 \\
0.50 \\
0.52 \\
0.34 \\
0.40 \\
0.45 \\
0.43 \\
0.40 \\
0.37 \\
0.38 \\
0.34 \\
0.50 \\
0.40 \\
0.45 \\
0.45 \\
0.41 \\
0.37 \\
0.38 \\
0.43 \\
0.43 \\
0.38 \\
0.37 \\
0.40 \\
0.36 \\
0.46 \\
0.17 \\
0.36 \\
0.46 \\
0.37 \\
0.48 \\
0.39 \\
0.34 \\
0.50 \\
0.49 \\
0.39 \\
0.47 \\
0.38 \\
0.45 \\
0.63 \\
0.36 \\
0.45 \\
0.68 \\
0.54 \\
0.36 \\
0.29\end{array}$ \\
\hline
\end{tabular}


5E. PULMONARY FUNCTION MEASUREMENTS FOR RATS EXPOSED VIA INHALATION TO SR90-FAP

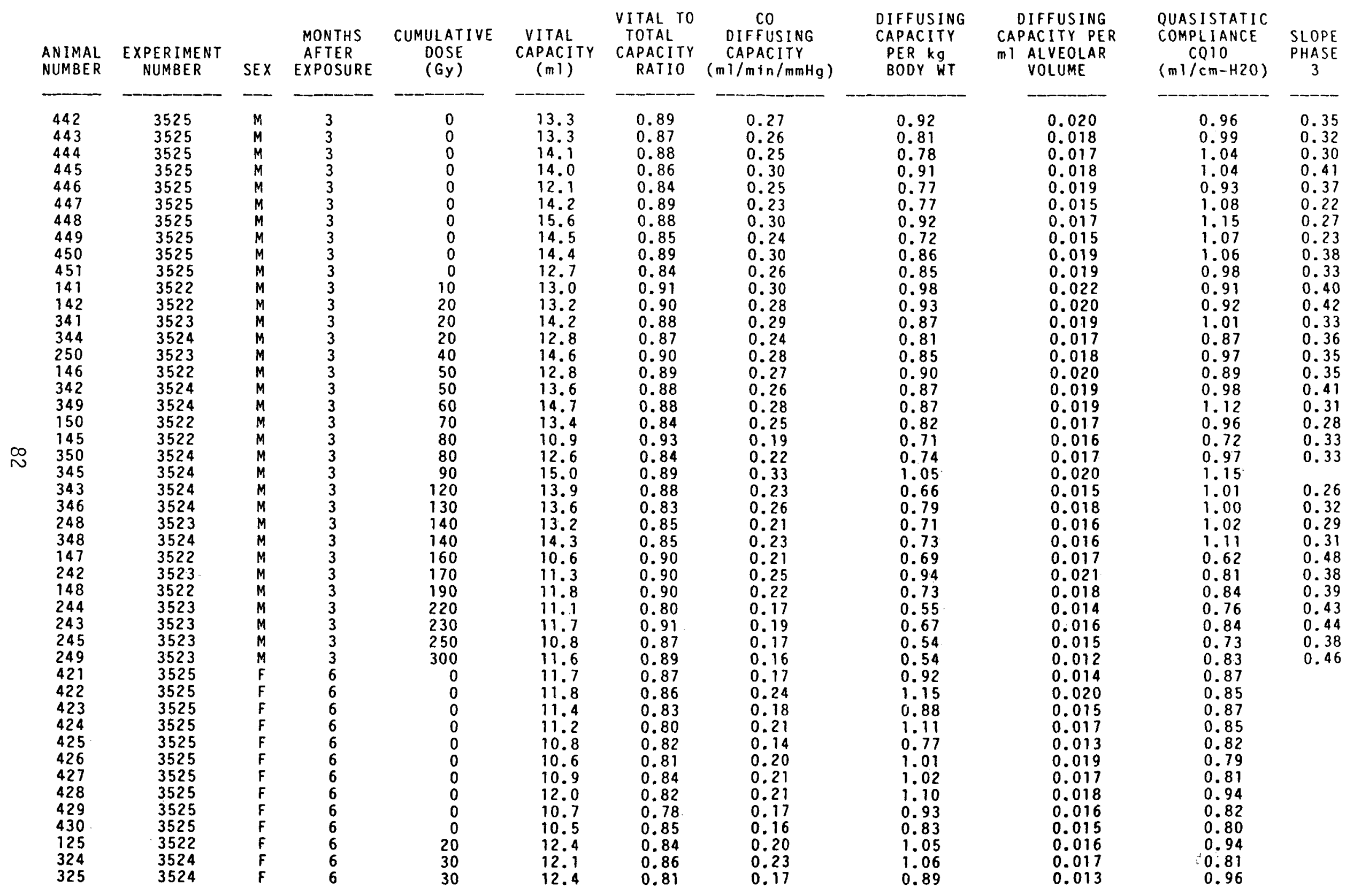


6F. PULMONARY FUNCTION MEASUREMENTS FOR RATS EXPOSED VIA INHALATION TO SR9O-FAP

\begin{tabular}{|c|c|c|c|c|c|c|c|c|c|c|c|}
\hline $\begin{array}{l}\text { ANIMAL } \\
\text { NUMBER }\end{array}$ & $\begin{array}{c}\text { EXPERIMENT } \\
\text { NUMBER }\end{array}$ & SEX & $\begin{array}{l}\text { MONTHS } \\
\text { AFTER } \\
\text { EXPOSURE }\end{array}$ & $\begin{array}{c}\text { CUMULATIVE } \\
\text { DOSE } \\
(\text { Gy) }\end{array}$ & $\begin{array}{l}\text { VITAL } \\
\text { CAPACITY } \\
(m 1)\end{array}$ & $\begin{array}{l}\text { VITAL TO } \\
\text { TOTAL } \\
\text { CAPACITY } \\
\text { RATIO }\end{array}$ & $\begin{array}{c}\text { CO } \\
\text { DIFFUSING } \\
\text { CAPACITY } \\
(\mathrm{mi} / \mathrm{min} / \mathrm{mmHg})\end{array}$ & $\begin{array}{l}\text { DIFFUSING } \\
\text { CAPACITY } \\
\text { PER kg } \\
\text { BODY WT }\end{array}$ & $\begin{array}{l}\text { DIFFUSING } \\
\text { CAPACITY PER } \\
\text { in ALVEOLAR } \\
\text { VOLUME }\end{array}$ & $\begin{array}{c}\text { QUASISTATIC } \\
\text { COMPLIANCE } \\
\text { CQ10 } \\
(\mathrm{m} 1 / \mathrm{cm}-\mathrm{H} 20)\end{array}$ & $\begin{array}{c}\text { SLOPE } \\
\text { PHASE } \\
3\end{array}$ \\
\hline $\begin{array}{l}327 \\
124 \\
129 \\
328 \\
323 \\
226 \\
326 \\
321 \\
322 \\
128 \\
228 \\
127 \\
225 \\
121 \\
221 \\
230 \\
222 \\
227 \\
229 \\
223 \\
130 \\
143 \\
347 \\
442 \\
443 \\
444 \\
445 \\
446 \\
447 \\
448 \\
449 \\
450 \\
451 \\
141 \\
142 \\
341 \\
344 \\
250 \\
146 \\
342 \\
349 \\
150 \\
350 \\
145 \\
345 \\
343\end{array}$ & $\begin{array}{l}3524 \\
3522 \\
3522 \\
3524 \\
3524 \\
3523 \\
3524 \\
3524 \\
3524 \\
3522 \\
3523 \\
3522 \\
3523 \\
3522 \\
3523 \\
3523 \\
3523 \\
3523 \\
3523 \\
3523 \\
3522 \\
3522 \\
3524 \\
3525 \\
3525 \\
3525 \\
3525 \\
3525 \\
3525 \\
3525 \\
3525 \\
3525 \\
3525 \\
3522 \\
3522 \\
3523 \\
3524 \\
3523 \\
3522 \\
3524 \\
3524 \\
3522 \\
3524 \\
3522 \\
3524 \\
3524\end{array}$ & 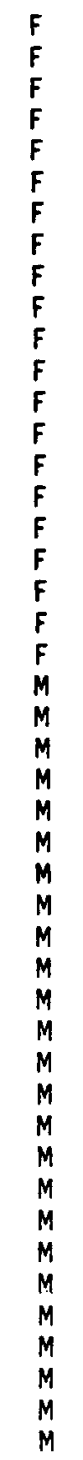 & $\begin{array}{l}6 \\
6 \\
6 \\
6 \\
6 \\
6 \\
6 \\
6 \\
6 \\
6 \\
6 \\
6 \\
6 \\
6 \\
6 \\
6 \\
6 \\
6 \\
6 \\
6 \\
6 \\
6 \\
6 \\
6 \\
6 \\
6 \\
6 \\
6 \\
6 \\
6 \\
6 \\
6 \\
6 \\
6 \\
6 \\
6 \\
6 \\
6 \\
6 \\
6 \\
6 \\
6 \\
6 \\
6 \\
6\end{array}$ & $\begin{array}{r}30 \\
40 \\
40 \\
40 \\
50 \\
60 \\
60 \\
70 \\
70 \\
80 \\
80 \\
90 \\
130 \\
140 \\
170 \\
190 \\
200 \\
230 \\
230 \\
290 \\
610 \\
0 \\
0 \\
0 \\
0 \\
0 \\
0 \\
0 \\
0 \\
0 \\
0 \\
0 \\
0 \\
0 \\
0 \\
0 \\
0 \\
0 \\
0 \\
20 \\
30 \\
30 \\
30 \\
30 \\
50 \\
70 \\
70 \\
80 \\
100 \\
110 \\
120 \\
140 \\
180\end{array}$ & $\begin{array}{r}12.2 \\
11.4 \\
11.0 \\
11.2 \\
11.0 \\
10.1 \\
12.1 \\
10.5 \\
10.9 \\
10.6 \\
13.1 \\
11.3 \\
10.3 \\
11.5 \\
10.0 \\
9.7 \\
10.2 \\
9.6 \\
10.9 \\
10.1 \\
2.5 \\
15.3 \\
15.1 \\
15.8 \\
14.0 \\
15.9 \\
16.6 \\
14.4 \\
15.7 \\
17.2 \\
15.7 \\
15.0 \\
14.6 \\
14.4 \\
15.0 \\
16.3 \\
14.3 \\
15.1 \\
14.8 \\
15.3 \\
15.3 \\
15.9 \\
13.3 \\
12.8 \\
15.6 \\
15.2\end{array}$ & $\begin{array}{l}0.85 \\
0.82 \\
0.82 \\
0.80 \\
0.81 \\
0.85 \\
0.84 \\
0.79 \\
0.85 \\
0.76 \\
0.86 \\
0.79 \\
0.81 \\
0.82 \\
0.81 \\
0.79 \\
0.83 \\
0.80 \\
0.86 \\
0.82 \\
0.52 \\
0.84 \\
0.88 \\
0.87 \\
0.79 \\
0.85 \\
0.91 \\
0.85 \\
0.89 \\
0.79 \\
0.80 \\
0.87 \\
0.78 \\
0.84 \\
0.85 \\
0.90 \\
0.79 \\
0.83 \\
0.83 \\
0.84 \\
0.85 \\
0.87 \\
0.86 \\
0.86 \\
0.82 \\
0.83\end{array}$ & $\begin{array}{l}0.21 \\
0.17 \\
0.21 \\
0.24 \\
0.21 \\
0.19 \\
0.22 \\
0.17 \\
0.20 \\
0.21 \\
0.23 \\
0.17 \\
0.16 \\
0.13 \\
0.16 \\
0.18 \\
0.13 \\
0.14 \\
0.16 \\
0.14 \\
0.02 \\
0.26 \\
0.28 \\
0.21 \\
0.22 \\
0.28 \\
0.28 \\
0.26 \\
0.26 \\
0.33 \\
0.27 \\
0.30 \\
0.26 \\
0.25 \\
0.29 \\
0.31 \\
0.23 \\
0.30 \\
0.29 \\
0.27 \\
0.31 \\
0.30 \\
0.23 \\
0.19 \\
0.27 \\
0.27\end{array}$ & $\begin{array}{l}1.00 \\
0.89 \\
1.02 \\
1.26 \\
1.00 \\
0.96 \\
1.11 \\
0.92 \\
1.01 \\
1.09 \\
1.06 \\
0.87 \\
0.87 \\
0.68 \\
0.79 \\
0.99 \\
0.71 \\
0.74 \\
0.80 \\
0.75 \\
0.15 \\
0.79 \\
0.81 \\
0.68 \\
0.62 \\
0.83 \\
0.75 \\
0.72 \\
0.77 \\
0.86 \\
0.75 \\
0.78 \\
0.75 \\
0.74 \\
0.99 \\
0.85 \\
0.74 \\
0.83 \\
0.89 \\
0.80 \\
0.90 \\
0.84 \\
0.75 \\
0.61 \\
0.79 \\
0.70\end{array}$ & $\begin{array}{l}0.017 \\
0.015 \\
0.018 \\
0.019 \\
0.0177 \\
0.017 \\
0.016 \\
0.016 \\
0.018 \\
0.017 \\
0.017 \\
0.014 \\
0.015 \\
0.011 \\
0.015 \\
0.017 \\
0.017 \\
0.013 \\
0.015 \\
0.013 \\
0.005 \\
0.016 \\
0.017 \\
0.013 \\
0.015\end{array}$ & $\begin{array}{l}0.93 \\
0.87 \\
0.84 \\
0.79 \\
0.83 \\
0.73 \\
0.92 \\
0.78 \\
0.77 \\
0.80 \\
0.96 \\
0.86 \\
0.76 \\
0.84 \\
0.73 \\
0.73 \\
0.77 \\
0.69 \\
0.76 \\
0.75 \\
0.16 \\
1.13 \\
1.07 \\
1.18 \\
1.02 \\
1.17 \\
1.24 \\
1.14 \\
1.18 \\
1.32 \\
1.12 \\
1.09 \\
1.14 \\
1.10 \\
1.14 \\
1.23 \\
1.01 \\
1.08 \\
1.05 \\
1.10 \\
1.20 \\
1.14 \\
0.98 \\
0.91 \\
1.16 \\
1.13\end{array}$ & \\
\hline
\end{tabular}


60. PULMONARY FUNCTION MEASUREMENTS FOR RATS EXPOSED VIA INHALATION TO SR9O-FAP

\begin{tabular}{|c|c|c|c|c|c|c|c|c|c|c|c|}
\hline $\begin{array}{l}\text { ANIMAL } \\
\text { NUMBER }\end{array}$ & $\begin{array}{l}\text { EXPERIMENT } \\
\text { NUMBER }\end{array}$ & SEX & $\begin{array}{l}\text { MONTHS } \\
\text { AFTER } \\
\text { EXPOSURE }\end{array}$ & $\begin{array}{c}\text { CUMULATIVE } \\
\text { DOSE } \\
(\text { Gy) }\end{array}$ & $\begin{array}{c}\text { VITAL } \\
\text { CAPAC I TY } \\
(\mathrm{ml})\end{array}$ & $\begin{array}{l}\text { VITAL TO } \\
\text { TOTAL } \\
\text { CAPACITY } \\
\text { RATIO }\end{array}$ & $\begin{array}{l}\quad \text { CO } \\
\text { DIFFUSING } \\
\text { CAPACITY } \\
(\mathrm{ml} / \mathrm{min} / \mathrm{mm})\end{array}$ & $\begin{array}{l}\text { DIFFUSING } \\
\text { CAPACITY } \\
\text { PER kg } \\
\text { BODY WT }\end{array}$ & $\begin{array}{l}\text { DIFFUSING } \\
\text { CAPACITY PER } \\
\text { m I ALVEOLAR } \\
\text { VOLUME }\end{array}$ & $\begin{array}{l}\text { QUASISTATIC } \\
\text { COMPLIANCE } \\
\text { CQIO } \\
(\mathrm{m} / / \mathrm{cm}-\mathrm{H} 20)\end{array}$ & $\begin{array}{c}\text { SLOPE } \\
\text { PHASE } \\
3\end{array}$ \\
\hline $\begin{array}{l}346 \\
348 \\
248 \\
147 \\
242 \\
148 \\
243 \\
244 \\
245 \\
421 \\
422 \\
423 \\
424 \\
425 \\
426 \\
427 \\
428 \\
429 \\
430 \\
125 \\
324 \\
325 \\
327 \\
328 \\
124 \\
129 \\
226 \\
323 \\
326 \\
321 \\
322 \\
128 \\
228 \\
127 \\
225 \\
121 \\
221 \\
230 \\
222 \\
227 \\
229 \\
223 \\
143 \\
347 \\
442 \\
443\end{array}$ & $\begin{array}{l}3524 \\
3524 \\
3523 \\
3522 \\
3523 \\
3522 \\
3523 \\
3523 \\
3523 \\
3525 \\
3525 \\
3525 \\
3525 \\
3525 \\
3525 \\
3525 \\
3525 \\
3525 \\
3525 \\
3522 \\
3524 \\
3524 \\
3524 \\
3524 \\
3522 \\
3522 \\
3523 \\
3524 \\
3524 \\
3524 \\
3524 \\
3522 \\
3523 \\
3522 \\
3523 \\
3522 \\
3523 \\
3523 \\
3523 \\
3523 \\
3523 \\
3523 \\
3522 \\
3524 \\
3525 \\
3525\end{array}$ & $\begin{array}{l}M \\
M \\
M \\
M \\
M \\
M \\
M \\
M \\
M \\
F \\
F \\
F \\
F \\
F \\
F \\
F \\
F \\
F \\
F \\
F \\
F \\
F \\
F \\
F \\
F \\
F \\
F \\
F \\
F \\
F \\
F \\
F \\
F \\
F \\
F \\
F \\
F \\
F \\
F \\
F\end{array}$ & $\begin{array}{l}6 \\
6 \\
6 \\
6 \\
6 \\
6 \\
6 \\
6 \\
6 \\
9 \\
9 \\
9 \\
9 \\
9 \\
9 \\
9 \\
9 \\
9 \\
9 \\
9 \\
9 \\
9 \\
9 \\
9 \\
9 \\
9 \\
9 \\
9 \\
9 \\
9 \\
9 \\
9 \\
9 \\
9 \\
9 \\
9 \\
9 \\
9 \\
9 \\
9 \\
9 \\
9 \\
9 \\
9 \\
9 \\
9\end{array}$ & $\begin{array}{r}200 \\
200 \\
210 \\
240 \\
260 \\
280 \\
330 \\
330 \\
370 \\
0 \\
0 \\
0 \\
0 \\
0 \\
0 \\
0 \\
0 \\
0 \\
0 \\
0 \\
30 \\
40 \\
40 \\
40 \\
40 \\
50 \\
50 \\
60 \\
60 \\
70 \\
80 \\
80 \\
90 \\
100 \\
110 \\
150 \\
160 \\
190 \\
230 \\
240 \\
260 \\
270 \\
340 \\
0 \\
0 \\
0 \\
0 \\
0 \\
0\end{array}$ & $\begin{array}{r}14.3 \\
15.7 \\
13.9 \\
16.1 \\
11.7 \\
12.6 \\
11.4 \\
12.1 \\
11.5 \\
11.3 \\
12.4 \\
11.7 \\
11.5 \\
10.2 \\
11.1 \\
10.3 \\
12.2 \\
11.6 \\
10.6 \\
12.8 \\
13.1 \\
13.1 \\
11.6 \\
12.4 \\
11.4 \\
12.0 \\
11.0 \\
11.8 \\
12.6 \\
11.9 \\
12.4 \\
99.8 \\
12.4 \\
11.7 \\
10.2 \\
11.1 \\
10.7 \\
9.5 \\
10.0 \\
9.3 \\
10.2 \\
9.9 \\
15.5 \\
16.3 \\
15.4 \\
15.6\end{array}$ & $\begin{array}{l}0.85 \\
0.85 \\
0.82 \\
0.89 \\
0.87 \\
0.78 \\
0.82 \\
0.83 \\
0.87 \\
0.83 \\
0.74 \\
0.87 \\
0.83 \\
0.86 \\
0.87 \\
0.79 \\
0.86 \\
0.87 \\
0.82 \\
0.74 \\
0.87 \\
0.83 \\
0.82 \\
0.87 \\
0.85 \\
0.83 \\
0.85 \\
0.84 \\
0.83 \\
0.88 \\
0.91 \\
0.79 \\
0.81 \\
0.80 \\
0.81 \\
0.87 \\
0.83 \\
0.86 \\
0.79 \\
0.81 \\
0.85 \\
0.79 \\
0.84 \\
0.91 \\
0.87 \\
0.84\end{array}$ & $\begin{array}{l}0.26 \\
0.31 \\
0.24 \\
0.24 \\
0.18 \\
0.24 \\
0.16 \\
0.16 \\
0.17 \\
0.20 \\
0.21 \\
0.20 \\
0.19 \\
0.20 \\
0.20 \\
0.20 \\
0.23 \\
0.19 \\
0.17 \\
0.23 \\
0.21 \\
0.24 \\
0.17 \\
0.25 \\
0.23 \\
0.21 \\
0.20 \\
0.25 \\
0.22 \\
0.20 \\
0.20 \\
0.28 \\
0.22 \\
0.19 \\
0.21 \\
0.23 \\
0.18 \\
0.14 \\
0.13 \\
0.15 \\
0.15 \\
0.14 \\
0.27 \\
0.38 \\
0.30 \\
0.31\end{array}$ & $\begin{array}{l}0.70 \\
0.92 \\
0.77 \\
0.72 \\
0.59 \\
0.74 \\
0.52 \\
0.45 \\
0.47 \\
0.98 \\
0.86 \\
0.97 \\
0.94 \\
1.01 \\
0.97 \\
0.87 \\
1.12 \\
0.95 \\
0.85 \\
1.15 \\
0.93 \\
1.18 \\
0.77 \\
1.23 \\
0.57 \\
0.92 \\
1.01 \\
1.03 \\
0.98 \\
0.93 \\
0.99 \\
1.39 \\
0.97 \\
0.93 \\
1.09 \\
1.08 \\
0.87 \\
0.68 \\
0.68 \\
0.74 \\
0.71 \\
0.68 \\
0.76 \\
1.05 \\
0.89 \\
0.80\end{array}$ & $\begin{array}{l}0.016 \\
0.019 \\
0.017 \\
0.014 \\
0.015 \\
0.018 \\
0.013 \\
0.013 \\
0.014 \\
0.018 \\
0.017 \\
0.015 \\
0.016 \\
0.018 \\
0.018 \\
0.017 \\
0.018 \\
0.016 \\
0.016 \\
0.018 \\
0.016 \\
0.019 \\
0.014 \\
0.019 \\
0.020 \\
0.0017 \\
0.018 \\
0.019\end{array}$ & $\begin{array}{l}1.04 \\
1.22 \\
1.03 \\
1.10 \\
0.82 \\
0.96 \\
0.80 \\
0.83 \\
0.77 \\
0.85 \\
0.98 \\
0.84 \\
0.91 \\
0.71 \\
0.81 \\
0.81 \\
0.92 \\
0.81 \\
0.73 \\
1.01 \\
0.99 \\
0.96 \\
0.88 \\
0.97 \\
0.83 \\
0.90 \\
0.84 \\
0.91 \\
1.01 \\
0.89 \\
0.88 \\
0.70 \\
0.99 \\
0.89 \\
0.79 \\
0.79 \\
0.81 \\
0.68 \\
0.77 \\
0.70 \\
0.75 \\
0.71 \\
1.19 \\
-1.15 \\
1.16 \\
1.24\end{array}$ & $\begin{array}{l} \\
\\
\\
\\
0.45 \\
0.42 \\
0.53 \\
0.48 \\
0.78 \\
0.64 \\
0.52 \\
0.50 \\
0.48 \\
0.57 \\
0.40 \\
0.44 \\
0.42 \\
0.54 \\
0.59 \\
0.57 \\
0.40 \\
0.63 \\
0.40 \\
0.45 \\
0.41 \\
0.38 \\
0.94 \\
0.48 \\
0.40 \\
0.80 \\
0.33 \\
0.48 \\
0.62 \\
0.66 \\
0.79 \\
0.58 \\
0.58 \\
0.31 \\
0.24 \\
0.45 \\
0.32\end{array}$ \\
\hline
\end{tabular}


6H. PULMONARY FUNCTION MEASUREMENTS FOR RATS EXPOSED VIA INHALATION TO SR90-FAP

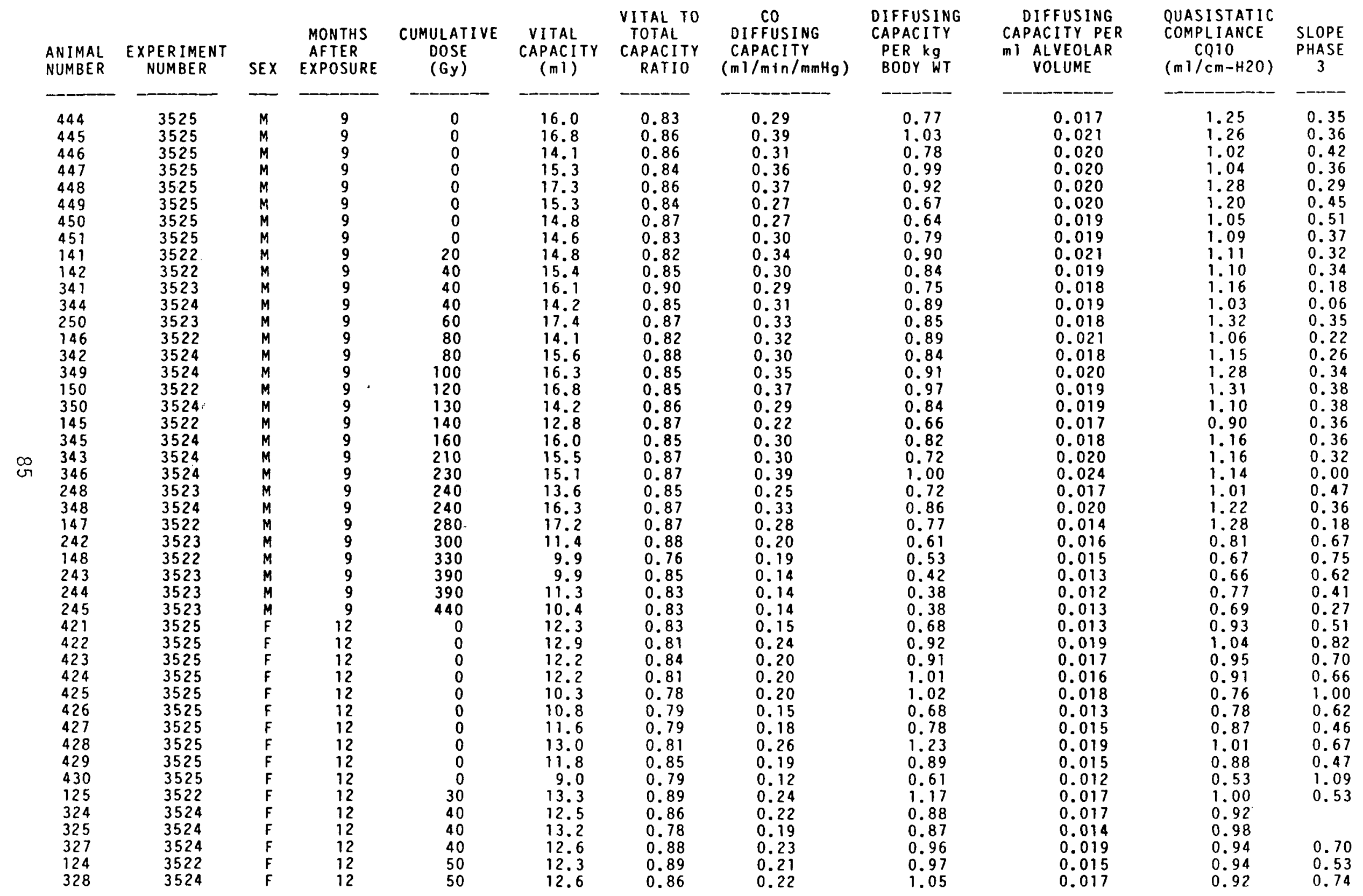


61. PULMONARY FUNCTION MEASUREMENTS FOR RATS EXPOSED VIA INHALATION TO SR9O-FAP

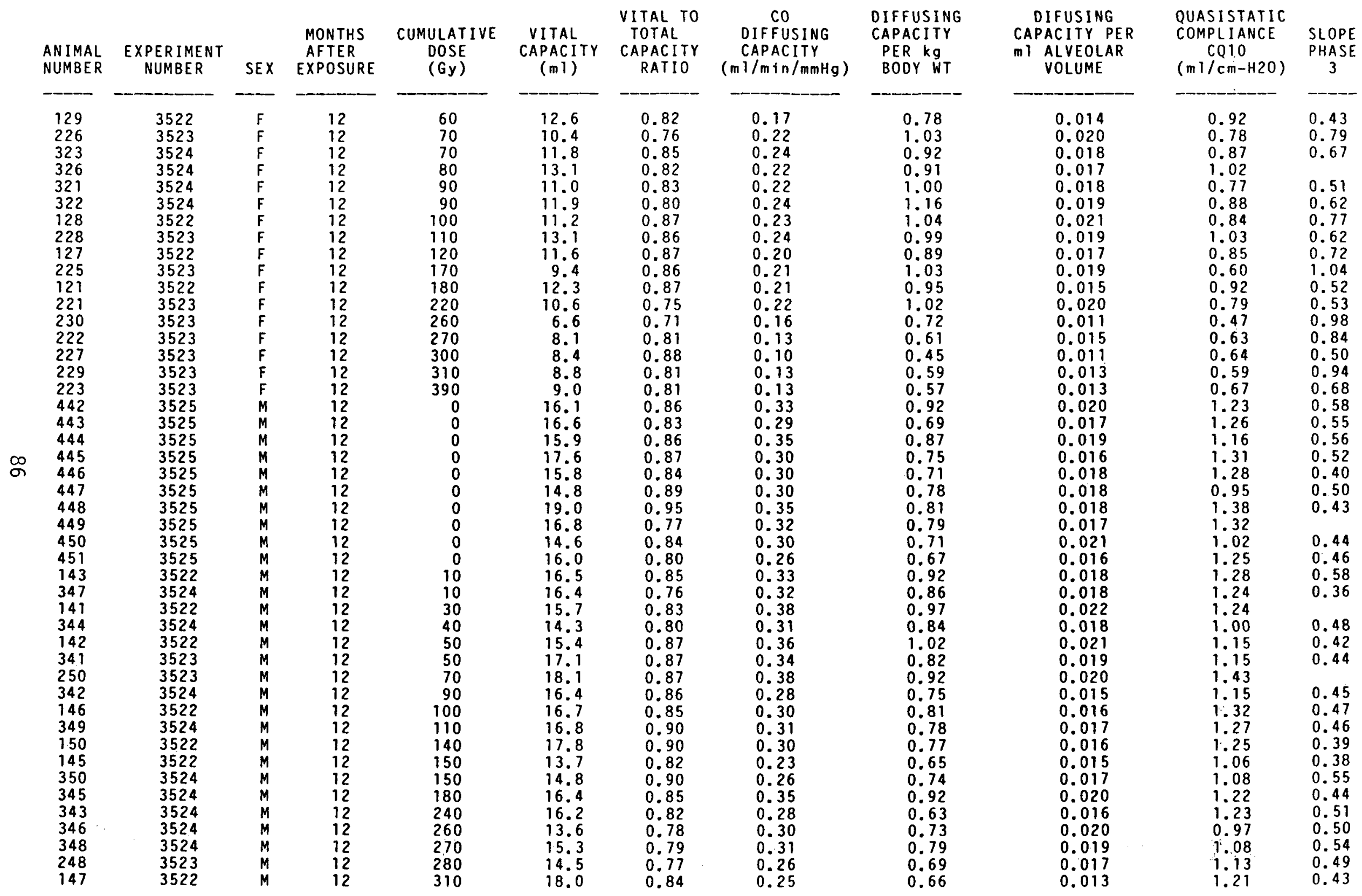


6J. PULMONARY FUNCTION MEASUREMENTS FOR RATS EXPOSED VIA INHALATION TO SR9O-FAP

\begin{tabular}{|c|c|c|c|c|c|c|c|c|c|c|c|}
\hline $\begin{array}{l}\text { ANIMAL } \\
\text { NUMBER }\end{array}$ & $\begin{array}{l}\text { EXPERIMENT } \\
\text { NUMBER }\end{array}$ & SEX & $\begin{array}{l}\text { MONTHS } \\
\text { AFTER } \\
\text { EXPOSURE }\end{array}$ & $\begin{array}{l}\text { CUMULATIVE } \\
\text { DOSE } \\
(\text { GY) }\end{array}$ & $\begin{array}{c}\text { VITAL } \\
\text { CAPACITY } \\
(\mathrm{ml})\end{array}$ & $\begin{array}{l}\text { VITAL TO } \\
\text { TOTAL } \\
\text { CAPACITY } \\
\text { RATIO }\end{array}$ & $\begin{array}{c}\text { CO } \\
\text { DIFFUSING } \\
\text { CAPACITY } \\
(\mathrm{m} 1 / \mathrm{m} 1 \mathrm{n} / \mathrm{mmHg})\end{array}$ & $\begin{array}{l}\text { DIFFUSING } \\
\text { CAPACITY } \\
\text { PER kg } \\
\text { BODY WT }\end{array}$ & $\begin{array}{l}\text { DIFFUSING } \\
\text { CAPACITY PER } \\
\text { mI ALVEOLAR } \\
\text { VOLUME }\end{array}$ & $\begin{array}{c}\text { QUASI ISTATIC } \\
\text { COMPLIANCE } \\
\text { CQIO } \\
(\mathrm{m} 1 / \mathrm{cm}-\mathrm{H} 2 \mathrm{O})\end{array}$ & $\begin{array}{c}\text { SLOPE } \\
\text { PHASE } \\
3\end{array}$ \\
\hline $\begin{array}{l}242 \\
148 \\
245 \\
421 \\
423 \\
424 \\
425 \\
426 \\
427 \\
428 \\
429 \\
430 \\
125 \\
324 \\
325 \\
327 \\
124 \\
129 \\
226 \\
323 \\
321 \\
322 \\
128 \\
228 \\
127 \\
225 \\
221 \\
442 \\
443 \\
444 \\
445 \\
446 \\
447 \\
448 \\
449 \\
450 \\
451 \\
143 \\
347 \\
141 \\
142 \\
341 \\
344 \\
250 \\
146 \\
349\end{array}$ & $\begin{array}{l}3523 \\
3522 \\
3523 \\
3525 \\
3525 \\
3525 \\
3525 \\
3525 \\
3525 \\
3525 \\
3525 \\
3525 \\
3522 \\
3524 \\
3524 \\
3524 \\
3522 \\
3522 \\
3523 \\
3524 \\
3524 \\
3524 \\
3522 \\
3523 \\
3522 \\
3523 \\
3523 \\
3525 \\
3525 \\
3525 \\
3525 \\
3525 \\
3525 \\
3525 \\
3525 \\
3525 \\
3525 \\
3522 \\
3524 \\
3522 \\
3522 \\
3523 \\
3524 \\
3523 \\
3522 \\
3524\end{array}$ & $\begin{array}{l}M \\
M \\
M \\
F \\
F \\
F \\
F \\
F \\
F \\
F \\
F \\
F \\
F \\
F \\
F \\
F \\
F \\
F \\
F \\
F \\
F \\
F \\
F \\
F \\
F \\
F \\
F \\
M \\
M \\
M \\
M \\
M \\
M \\
M \\
M \\
M \\
M \\
M \\
M \\
M \\
M \\
M \\
M \\
M \\
M \\
M\end{array}$ & 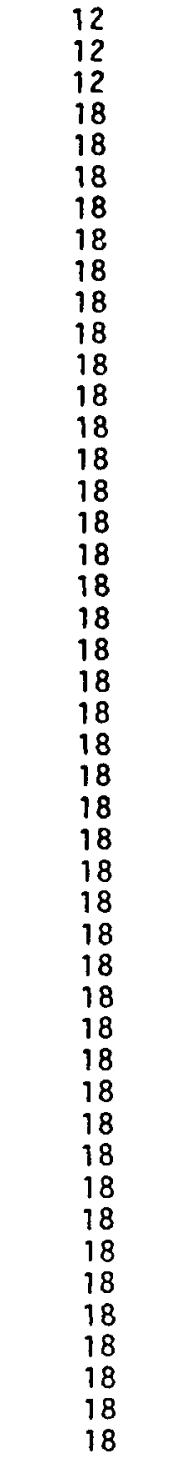 & $\begin{array}{r}340 \\
380 \\
500 \\
0 \\
0 \\
0 \\
0 \\
0 \\
0 \\
0 \\
0 \\
0 \\
0 \\
30 \\
50 \\
50 \\
50 \\
50 \\
60 \\
60 \\
80 \\
80 \\
100 \\
100 \\
110 \\
120 \\
140 \\
190 \\
240 \\
0 \\
0 \\
0 \\
0 \\
0 \\
0 \\
0 \\
0 \\
0 \\
0 \\
0 \\
0 \\
10 \\
10 \\
10 \\
30 \\
50 \\
50 \\
50 \\
80 \\
110 \\
120\end{array}$ & $\begin{array}{r}10.9 \\
11.5 \\
8.6 \\
11.9 \\
12.7 \\
13.0 \\
11.6 \\
12.4 \\
12.3 \\
12.5 \\
12.5 \\
11.3 \\
13.1 \\
12.8 \\
14.6 \\
13.3 \\
12.1 \\
12.8 \\
11.4 \\
12.2 \\
11.8 \\
12.5 \\
12.4 \\
11.8 \\
11.8 \\
9.9 \\
4.5 \\
15.9 \\
17.2 \\
16.2 \\
18.1 \\
15.5 \\
16.9 \\
19.5 \\
16.7 \\
16.6 \\
16.5 \\
17.3 \\
17.3 \\
16.6 \\
16.8 \\
17.4 \\
17.3 \\
15.7 \\
17.1 \\
16.6\end{array}$ & $\begin{array}{l}0.69 \\
0.85 \\
0.84 \\
0.86 \\
0.78 \\
0.86 \\
0.84 \\
0.87 \\
0.84 \\
0.82 \\
0.79 \\
0.84 \\
0.82 \\
0.83 \\
0.92 \\
0.85 \\
0.88 \\
0.90 \\
0.82 \\
0.79 \\
0.82 \\
0.88 \\
0.88 \\
0.83 \\
0.86 \\
0.83 \\
0.53 \\
0.82 \\
0.87 \\
0.83 \\
0.85 \\
0.84 \\
0.85 \\
0.87 \\
0.83 \\
0.86 \\
0.86 \\
0.87 \\
0.82 \\
0.84 \\
0.88 \\
0.85 \\
0.82 \\
0.81 \\
0.85 \\
0.85\end{array}$ & $\begin{array}{l}0.15 \\
0.21 \\
0.12 \\
0.23 \\
0.20 \\
0.22 \\
0.22 \\
0.23 \\
0.22 \\
0.21 \\
0.24 \\
0.22 \\
0.23 \\
0.23 \\
0.22 \\
0.27 \\
0.20 \\
0.18 \\
0.26 \\
0.22 \\
0.21 \\
0.22 \\
0.20 \\
0.24 \\
0.20 \\
0.18 \\
0.07 \\
0.32 \\
0.35 \\
0.32 \\
0.32 \\
0.28 \\
0.30 \\
0.41 \\
0.33 \\
0.33 \\
0.25 \\
0.28 \\
0.28 \\
0.34 \\
0.29 \\
0.40 \\
0.21 \\
0.39 \\
0.27 \\
0.32\end{array}$ & $\begin{array}{l}0.45 \\
0.57 \\
0.33 \\
0.92 \\
0.77 \\
1.01 \\
0.96 \\
0.90 \\
0.83 \\
0.86 \\
0.99 \\
0.88 \\
1.02 \\
0.89 \\
0.88 \\
0.97 \\
0.79 \\
0.72 \\
1.03 \\
0.76 \\
0.83 \\
0.95 \\
0.90 \\
0.88 \\
0.80 \\
0.79 \\
0.35 \\
0.87 \\
0.82 \\
0.81 \\
0.81 \\
0.66 \\
0.79 \\
0.91 \\
0.83 \\
0.78 \\
0.63 \\
0.72 \\
0.78 \\
0.84 \\
0.81 \\
0.99 \\
0.53 \\
0.97 \\
0.72 \\
0.81\end{array}$ & $\begin{array}{l}0.012 \\
0.016 \\
0.012 \\
0.017 \\
0.014 \\
0.017 \\
0.018 \\
0.018 \\
0.017 \\
0.017 \\
0.018 \\
0.019 \\
0.017 \\
0.016 \\
0.015\end{array}$ & $\begin{array}{l}0.79 \\
0.78 \\
0.48 \\
0.85 \\
1.03 \\
0.97 \\
0.80 \\
0.88 \\
0.88 \\
0.93 \\
1.03 \\
0.82 \\
1.00 \\
0.92 \\
1.06 \\
0.98 \\
0.84 \\
0.86 \\
0.89 \\
0.94 \\
0.85 \\
0.82 \\
0.89 \\
0.77 \\
0.88 \\
0.73 \\
0.36 \\
1.24 \\
1.29 \\
1.25 \\
1.36 \\
1.17 \\
1.30 \\
1.51 \\
1.25 \\
1.24 \\
1.27 \\
1.34 \\
1.31 \\
1.30 \\
1.26 \\
1.31 \\
1.41 \\
1.14 \\
1.29 \\
1.27\end{array}$ & $\begin{array}{l}0.92 \\
0.92 \\
2.01 \\
0.70 \\
0.37 \\
0.54 \\
0.87 \\
0.78 \\
0.55 \\
0.68 \\
0.61 \\
0.82 \\
0.47 \\
0.51 \\
0.55 \\
0.65 \\
0.75 \\
0.42 \\
0.83 \\
0.25 \\
0.56 \\
0.69 \\
0.60 \\
0.48 \\
0.57 \\
1.19 \\
0.64 \\
0.48 \\
0.36 \\
0.40 \\
0.25 \\
0.33 \\
0.34 \\
0.33 \\
0.16 \\
0.36 \\
0.32 \\
0.25 \\
0.35 \\
0.32 \\
0.24 \\
0.26 \\
0.24 \\
0.43 \\
0.28 \\
0.24\end{array}$ \\
\hline
\end{tabular}


6K. PULMONARY FUNCTION MEASUREMENTS FOR RATS EXPOSED VIA INHALATION TO SR9O-FAP

\begin{tabular}{lc} 
ANIMAL \\
NUMBER & $\begin{array}{c}\text { EXPERIMENT } \\
\text { NUMBER }\end{array}$ \\
\hline 150 & -3522 \\
350 & 3524 \\
145 & 3522 \\
345 & 3524 \\
343 & 3524 \\
346 & 3524 \\
348 & 3524
\end{tabular}

\begin{tabular}{|c|c|c|c|c|c|c|}
\hline SEX & $\begin{array}{l}\text { MONTHS } \\
\text { AFTER } \\
\text { EXPOSURE }\end{array}$ & $\begin{array}{c}\text { CUMULATIVE } \\
\text { DOSE } \\
\text { (Gy) }\end{array}$ & $\begin{array}{c}\text { VITAL } \\
\text { CAPACITY } \\
(\mathrm{ml})\end{array}$ & $\begin{array}{l}\text { VITAL TO } \\
\text { TOTAL } \\
\text { CAPACITY } \\
\text { RATIO }\end{array}$ & $\begin{array}{c}\text { CO } \\
\text { DIFFUSING } \\
\text { CAPACITY } \\
(\mathrm{mi} / \mathrm{min} / \mathrm{mmHg})\end{array}$ & $\begin{array}{l}\text { OIFFUSING } \\
\text { CAPACITY } \\
\text { PER kg } \\
\text { BODY WT }\end{array}$ \\
\hline $\begin{array}{l}M \\
M \\
M \\
M \\
M \\
M \\
M\end{array}$ & $\begin{array}{l}18 \\
18 \\
18 \\
18 \\
18 \\
18 \\
18\end{array}$ & $\begin{array}{l}150 \\
160 \\
170 \\
200 \\
270 \\
290 \\
290\end{array}$ & $\begin{array}{l}17.3 \\
14.4 \\
14.2 \\
16.8 \\
17.4 \\
14.8 \\
17.2\end{array}$ & $\begin{array}{l}0.83 \\
0.84 \\
0.82 \\
0.84 \\
0.86 \\
0.82 \\
0.86\end{array}$ & $\begin{array}{l}0.26 \\
0.28 \\
0.26 \\
0.33 \\
0.31 \\
0.29 \\
0.32\end{array}$ & $\begin{array}{l}0.66 \\
0.75 \\
0.73 \\
0.88 \\
0.73 \\
0.70 \\
0.83\end{array}$ \\
\hline
\end{tabular}

\begin{tabular}{l} 
DIFFUSING \\
CAPACITY PER \\
m I ALVEOLAR \\
VOLUME \\
\hline 0.015 \\
\hline 0.018 \\
0.018 \\
0.018 \\
0.018 \\
0.018 \\
0.018
\end{tabular}

QUASISTATIC COMPLIANCE SLOPE

CQIO

PHASE $(\mathrm{ml} / \mathrm{cm}-\mathrm{H} 2 \mathrm{O})$ 3

1.30
1.11
1.02
1.22
1.29
0.98
1.37

0.44

0.29

0.56

0.42

0.30

0.30

0.42
0.33 
6. PULMONARY FUNCTION MEASUREMENTS FOR RATS EXPOSED VIA INHALATION TO Y9O-FAP

\begin{tabular}{|c|c|c|c|c|c|c|c|c|c|c|}
\hline $\begin{array}{l}\text { ANIMAL } \\
\text { NUMBER }\end{array}$ & SEX & $\begin{array}{l}\text { MONTHS } \\
\text { AFTER } \\
\text { EXPOSURE }\end{array}$ & $\begin{array}{l}\text { CUMULATIVE } \\
\text { DOSE } \\
(G Y)\end{array}$ & $\begin{array}{l}\text { VITAL } \\
\text { CAPACITY } \\
(m 1)\end{array}$ & $\begin{array}{l}\text { VITAL TO } \\
\text { TOTAL } \\
\text { CAPACITY } \\
\text { RATIO }\end{array}$ & $\begin{array}{c}\text { CO } \\
\text { DIFFUSING } \\
\text { CAPACITY } \\
(\mathrm{m} 1 / \mathrm{m} \mathrm{in} / \mathrm{mm})\end{array}$ & $\begin{array}{l}\text { DIFFUS ING } \\
\text { CAPACI TY } \\
\text { PER kg } \\
\text { BODY WT }\end{array}$ & $\begin{array}{l}\text { DIFFUSING } \\
\text { CAPACITY PER } \\
\text { mI ALVEOLAR } \\
\text { VOLUME }\end{array}$ & $\begin{array}{c}\text { QUASISTATIC } \\
\text { COMPLIANCE } \\
\text { CQIO } \\
(\mathrm{m} 1 / \mathrm{cm}-\mathrm{H} 2 \mathrm{O})\end{array}$ & $\begin{array}{c}\text { SLOPE } \\
\text { PHASE } \\
3\end{array}$ \\
\hline $\begin{array}{l}201 \\
202 \\
203 \\
207 \\
259 \\
261 \\
264 \\
302 \\
304 \\
359 \\
362 \\
363 \\
344 \\
318 \\
315 \\
345 \\
128 \\
342 \\
120 \\
316 \\
125 \\
122 \\
317 \\
113 \\
115 \\
313 \\
154 \\
142 \\
326 \\
102 \\
116 \\
127 \\
158 \\
352 \\
170 \\
353 \\
130 \\
129 \\
101 \\
156 \\
343 \\
246 \\
160 \\
166 \\
165 \\
146 \\
151 \\
169\end{array}$ & 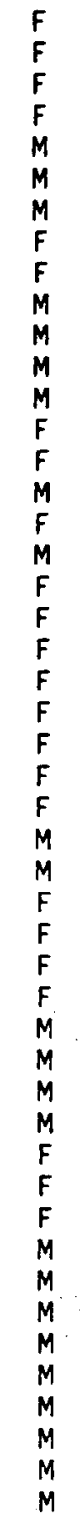 & $\begin{array}{l}18 \\
18 \\
18 \\
18 \\
18 \\
18 \\
18 \\
18 \\
18 \\
18 \\
18 \\
18 \\
18 \\
18 \\
18 \\
18 \\
18 \\
18 \\
18 \\
18 \\
18 \\
18 \\
18 \\
18 \\
18 \\
18 \\
18 \\
18 \\
18 \\
18 \\
18 \\
18 \\
18 \\
18 \\
18 \\
18 \\
18 \\
18 \\
18 \\
18 \\
18 \\
18 \\
18 \\
18 \\
\mid \begin{array}{l}\mid \\
\mid\end{array} \\
18 \\
18 \\
18 \\
18 \\
18\end{array}$ & $\begin{array}{r}0 \\
0 \\
0 \\
0 \\
0 \\
0 \\
0 \\
0 \\
0 \\
0 \\
0 \\
0 \\
0 \\
0 \\
30 \\
60 \\
60 \\
60 \\
70 \\
80 \\
80 \\
90 \\
90 \\
90 \\
90 \\
100 \\
110 \\
110 \\
120 \\
120 \\
120 \\
120 \\
130 \\
130 \\
150 \\
150 \\
150 \\
150 \\
160 \\
160 \\
170 \\
180 \\
180 \\
180 \\
190 \\
200 \\
210 \\
220 \\
220 \\
230 \\
260 \\
280\end{array}$ & $\begin{array}{r}10.2 \\
10.3 \\
10.3 \\
9.4 \\
15.8 \\
14.9 \\
14.0 \\
10.2 \\
11.8 \\
14.6 \\
16.3 \\
16.9 \\
16.5 \\
11.5 \\
10.4 \\
16.0 \\
12.4 \\
13.8 \\
11.8 \\
10.5 \\
11.6 \\
11.0 \\
10.2 \\
11.1 \\
11.3 \\
10.4 \\
15.6 \\
14.6 \\
9.8 \\
7.1 \\
9.5 \\
7.4 \\
7.4 \\
14.1 \\
16.2 \\
15.6 \\
11.5 \\
6.5 \\
12.8 \\
15.5 \\
13.8 \\
11.9 \\
15.9 \\
14.1 \\
16.6 \\
14.9 \\
13.2 \\
12.8\end{array}$ & $\begin{array}{l}0.85 \\
0.88 \\
0.88 \\
0.86 \\
0.90 \\
0.88 \\
0.79 \\
0.91 \\
0.93 \\
0.94 \\
0.89 \\
0.91 \\
0.94 \\
0.89 \\
0.88 \\
0.93 \\
0.87 \\
0.90 \\
0.89 \\
0.88 \\
0.87 \\
0.90 \\
0.88 \\
0.85 \\
0.92 \\
0.89 \\
0.92 \\
0.93 \\
0.88 \\
0.83 \\
0.89 \\
0.94 \\
0.82 \\
0.87 \\
0.90 \\
0.89 \\
0.86 \\
0.86 \\
0.90 \\
0.86 \\
0.92 \\
0.84 \\
0.98 \\
0.86 \\
0.88 \\
0.94 \\
0.91 \\
0.95\end{array}$ & $\begin{array}{l}0.20 \\
0.19 \\
0.20 \\
0.15 \\
0.33 \\
0.37 \\
0.34 \\
0.20 \\
0.19 \\
0.32 \\
0.34 \\
0.40 \\
0.37 \\
0.23 \\
0.19 \\
0.35 \\
0.25 \\
0.29 \\
0.24 \\
0.21 \\
0.25 \\
0.24 \\
0.19 \\
0.20 \\
0.24 \\
0.21 \\
0.30 \\
0.30 \\
0.15 \\
0.11 \\
0.18 \\
0.11 \\
0.24 \\
0.29 \\
0.33 \\
0.30 \\
0.10 \\
0.10 \\
0.18 \\
0.26 \\
0.36 \\
0.15 \\
0.24 \\
0.29 \\
0.35 \\
0.31 \\
0.25 \\
0.24\end{array}$ & $\begin{array}{l}0.86 \\
0.92 \\
0.86 \\
0.74 \\
0.81 \\
0.91 \\
0.77 \\
0.90 \\
0.76 \\
0.78 \\
0.76 \\
0.95 \\
0.91 \\
0.97 \\
0.85 \\
0.93 \\
0.99 \\
0.76 \\
0.92 \\
0.96 \\
0.96 \\
1.00 \\
0.81 \\
0.74 \\
1.06 \\
0.85 \\
0.77 \\
0.87 \\
0.57 \\
0.48 \\
0.73 \\
0.51 \\
0.61 \\
0.73 \\
0.71 \\
0.74 \\
0.41 \\
0.43 \\
1.04 \\
0.63 \\
0.96 \\
0.44 \\
0.81 \\
0.78 \\
0.80 \\
0.76 \\
0.64 \\
0.56\end{array}$ & $\begin{array}{l}0.019 \\
0.018 \\
0.016 \\
0.014 \\
0.019 \\
0.022 \\
0.021 \\
0.017 \\
0.014 \\
0.021 \\
0.019 \\
0.020 \\
0.020 \\
0.019 \\
0.017 \\
0.021 \\
0.019 \\
0.017 \\
0.018 \\
0.018 \\
0.020 \\
0.021 \\
0.017 \\
0.016 \\
0.019 \\
0.019 \\
0.017 \\
0.018 \\
0.013 \\
0.014 \\
0.017 \\
0.013 \\
0.015 \\
0.019 \\
0.019\end{array}$ & $\begin{array}{l}0.80 \\
0.78 \\
0.73 \\
0.72 \\
1.19 \\
1.09 \\
0.97 \\
0.76 \\
0.88 \\
1.06 \\
1.27 \\
1.28 \\
1.24 \\
0.87 \\
0.72 \\
0.72 \\
1.24 \\
0.98 \\
1.01 \\
0.84 \\
0.76 \\
0.76 \\
0.87 \\
0.79 \\
0.72 \\
0.79 \\
0.78 \\
0.70 \\
0\end{array}$ & $\begin{array}{l}0.33 \\
0.37 \\
0.40 \\
0.80 \\
0.31 \\
0.24 \\
0.17 \\
0.36 \\
0.46 \\
0.18 \\
0.22 \\
0.48 \\
0.18 \\
0.32 \\
0.47 \\
0.31 \\
0.30 \\
0.31 \\
0.65 \\
0.38 \\
0.65 \\
0.25 \\
0.32 \\
0.32 \\
0.62 \\
0.65 \\
0.23 \\
0.17 \\
0.44 \\
1.03 \\
0.56 \\
1.08 \\
1.08 \\
0.44 \\
0.12 \\
0.20 \\
0.36 \\
2.78 \\
0.44 \\
0.34 \\
0.36 \\
0.34 \\
0.29 \\
0.43 \\
0.15 \\
0.32 \\
0.29 \\
0.50\end{array}$ \\
\hline
\end{tabular}


SEE INSTRUCTIONS ON THE REVERSE.

NUREG/CR -5025

2. TITLE AND SUBTITLE

Experimental Studies of the Early Effects of Inhaled

Beta-Emitting Radionuclides for Nuclear Accident Risk

Assessment - Phase II Report

5. AUTHORIS)

B. R. Scott, F. F. Hahn, G. J. Newton, M. B. Snipes,

E. G. Damon, J. L. Mauder ly, B. B. Boecker and D. H. Gray

7. PERFORMING ORGANIZATION NAME AND MAILING ADDRESS (Inc/ude $Z, p$ Code)

Inhalation Toxicology Research Institute

Lovelace Biomedical and Environmental Research Institute

P.0. Box 5890

Albuquerque, NM 87185

10. SPONSORING ORGANIZATION NAME ANO MAILING AODRESS /InClude Zio COde/

FIN No. A1203

Division of Regulatory Applications

Office of Nuclear Regulatory Research

LEAVE BLANK

U.S. Nuclear Regulatory Commission

Washington, DC 20555

12. SUPPLEMENTARY NOTES

13. ABSTRACT 200 words or less)

This report summarizes a series of experiments concerning the effect of linear energy transfer and temporal radiation dose pattern to the lung from inhaled beta-emitting radionuclides. The results were used to test the validity of a hazard-function mathematical model for predicting death from radiation pneumonitis. Both morbidity and mortality within 18 months after exposure were examined in rats exposed to beta emitting radionuclides, giving brief or protracted irradiation of the lung or having weak or strong beta emissions. Protraction of the radiation dose to the lung from a lung half time of less than 3 days to a lung half time of 150 days has a sparing effect with a factor of 1.7. Low energy beta emissions have a similar effectiveness in producing lethal injury as high energy beta emissions. The hazard function model for predicting death adequately predicted the median lethal doses for rats.

\begin{tabular}{|c|c|}
\hline \multirow{7}{*}{ 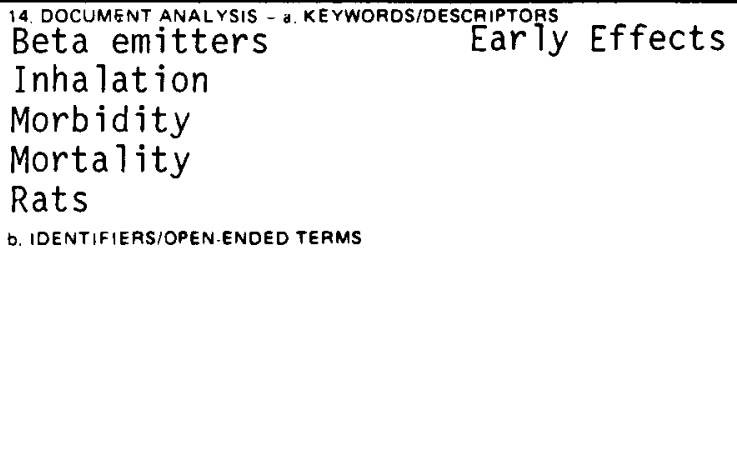 } & $\begin{array}{l}\text { 15. AVAILABILITY } \\
\text { STATEMENT } \\
\text { UNL IMI TED }\end{array}$ \\
\hline & 16. SECURITY CLASSIFICATION \\
\hline & $\begin{array}{l}\text { This pages } \\
\text { UNCLASSIF IED }\end{array}$ \\
\hline & (This report) \\
\hline & UNCLASSIFIED \\
\hline & 17. NUMBER OF PAGES \\
\hline & 18. PRICE \\
\hline
\end{tabular}

